Andrews University

Digital Commons @ Andrews University

1977

\title{
An Analysis of the Role and Functions Expected of a Seventh-day Adventist Pastor: As a Basis for Negotiating an Intentional Ministry
}

Victor Ralph Brown

Andrews University

Follow this and additional works at: https://digitalcommons.andrews.edu/dmin

Part of the Practical Theology Commons

\section{Recommended Citation}

Brown, Victor Ralph, "An Analysis of the Role and Functions Expected of a Seventh-day Adventist Pastor: As a Basis for Negotiating an Intentional Ministry" (1977). Professional Dissertations DMin. 531.

https://dx.doi.org/10.32597/dmin/531

https://digitalcommons.andrews.edu/dmin/531

This Project Report is brought to you for free and open access by the Graduate Research at Digital Commons @ Andrews University. It has been accepted for inclusion in Professional Dissertations DMin by an authorized administrator of Digital Commons @ Andrews University. For more information, please contact repository@andrews.edu. 


\section{ABSTRACT}

\section{AN ANALYSIS OF THE ROLE AND FUNCTIONS EXPECTED OF A SEVENTH-DAY ADVENTIST PASTOR AS A BASIS FOR NEGOTIATING AN INTENTIONAL MINISTRY}

by

Victor R. Brown

Chairperson: Arnold Kurtz 


\section{ABSTRACT OF GRADUATE STUDENT RESEARCH \\ Project Report}

Andrews University

Seventh-day Adventist Theological Seminary

Title: AN ANALYSIS OF THE ROLE AND FUNCTIONS EXPECTED OF A SEVENTH-DAY ADVENTIST PASTOR AS A BASIS FOR NEGOTIATING AN INTENTIONAL MINISTRY

Name of researcher: Victor R. Brown

Name and title of faculty adviser: Arnold Kurtz

Date completed: May 1977

Since its organization in 1863, the Seventh-day Adventist denomination has grown from a small group to a significant religious movement in the world today. Originally all ministers in the church were evangelists. There were to be no "settied" pastors of local congregations. Local churches relied upon local talent selected from their own ranks for pastoral leadership.

The change created by increased numbers and the demands of the laity has meant the role of the ordained minister in the local Seventh-day Adventist church has been considerably altered from its original concept. This has caused many to be confused 
as to just what is the role of the local pastor. The result: pastoral frustration, overload, internal and external conflict, and reduced growth in local churches.

Two factors that may hinder full clarification of the local Seventh-day Adventist pastor's role are: (1) too general an approach, in which leaders and pastors fail to particularize the role to a specific place and group; and (2) a lack of selfexamination and assessment on the part of both the pastor and his congregation.

This project developed out of the writer's seventeen years of pastoral experience, his interest in the pastoral office, and as a fulfillment of the requirements for the Doctor of Ministry degree. It is the thesis of this study that considerable conflict and frustration exists among the conference, the local congregation, and the various subgroups within the church concerning their mutual ministries in the church.

This project was conceived as an analysis of a local Seventh-day Adventist church's expectations of its pastor in terms of attitudes, work life, and leadership style. It was also designed to suggest a model by which possible role conflict experienced by the pastor may be resolved. This model suggests that the pastor negotiate his role conflicts with his congregation and conference openly rather than keep them to himself. It means that the pastor must initiate the process, make his own self-assessment, and obtain information from his congregation and conference concerning their expectations of him. When this is done the 
negotiation process may begin. Out of this process a newly created ministry emerges that is mutually agreed upon and is mutually implemented.

The procedure of this study requires five steps of the pastor: (1) he takes an assessment of himself, his goals, talents, skills, and personal strengths and weaknesses; (2) he develops an attitude and a preference data-gathering instrument; (3) he administers the survey to the significant others in his work 1ife, such as the congregation, conference officials and committee members, and fellow ministers; (4) he analyzes the responses to the survey utilizing the latest available devices for determining the significance of disagreement between the respondent groups; and (5) he utilizes the information obtained as a basis for an ongoing negotiative type ministry.

This report describes one pastor's attempt to follow, as far as possible, the above-mentioned steps. The writer, the focal pastor of this study, allows the reader to look over his shoulder as he attempts to obtain a clearer picture of the pastor's role, to discern the sources of expectation in the church, to do a selfassessment, and analyze and interpret responses by his congregation to a questionnaire. The information and skills acquired will be useful to the writer in future pastoral relationships and perhaps to others who may be laboring presently. in the pastorate. 
Andrews University

Seventh-day Adventist Theological Seminary

AN ANALYSIS OF THE ROLE AND FUNCTIONS EXPECTED OF A SEVENTHDAY ADVENTIST PASTOR AS A BASIS FOR NEGOTIATING

AN INTENTIONAL MINISTRY

\author{
A Project Report \\ Presented in Partial Fulfillment \\ of the Requirements for the Degree \\ Doctor of Ministry
}

by

Victor R. Brown

May 1977 


\section{AN ANALYSIS OF THE ROLE AND FUNCTIONS EXPECTED OF A SEVENTH-DAY ADVENTIST PASTOR AS A BASIS FOR \\ NEGOTIATING AN INTENTIONAL MINISTRY}

A project presented

in partial fulfillment of the requirements

for the degree

Dactor of Ministry

by

Victor R. Brown

APPROVAL BY THE COMMITTEE:

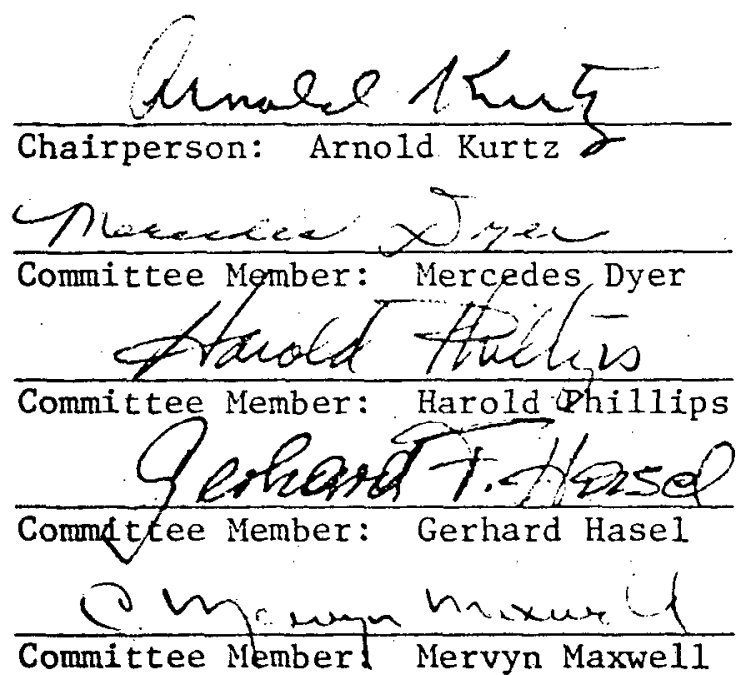

$\frac{5 / 24 / 77}{\text { Date approved }}$

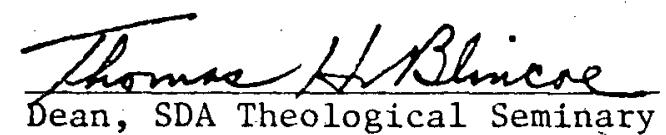


TABLE OF CONTENTS

LIST OF TABLES . . . . . . . . . . . . . . . . . ix

LIST OF FIGURE . . . . . . . . . . . . . . . . . . $\quad x i$

\section{Chapter}

I. INTRODUCTION . . . . . . . . . . . . . . . 1

The Justification of the Project . . . . . . . . . 1

Changes Since the Church was Organized . . . . . 2

The church has grown in numbers . . . . . . 2

Sociological and technological changes..... 3

Confusion About the Pastor's Function . . . . . . . 4

The Task and Challenge of this Study . . . . . . . 7

Procedure and Methodology . . . . . . . . . 9

The Limitations of this Study . . . . . . . . . . 11

Objectives.................. . . 13

Definitions . . . . . . . . . . . . . . 14

Overview of Study ................ . . . 15

II. THE LOCAL CHURCH AS A RELIGIOUS SOCIAL SYSTEM • • • • 17

The Church as a Local Religious Unit . . . . . . . 17

A Leadership of Necessity . . . . . . . . . 21

The Church is Voluntary . . . . . . . . . . . 25

The Church as a Voluntary Religious Social System . 27

The Forces that Bind the System Together . . . . 28

Expectations of the Leader within a 30

Voluntary Religious Social System . . . . . . . 30

The Volunteer Servant . . . . . . . . . . 30

The Blessings and Curses of Voluntaryism . . . . . 31

Socialization and Voluntaryism . . . . . . . 33

The Local Seventh-day Adventist Church

as a Religious Social System . . . . . . . . 35

The Special Influence of Ellen G. White . . . . 37

Organization and Development of the

Seventh-day Adventist Church . . . . . . 39

The Local Seventh-day Adventist Church Today. . . 41

Implications for the Local Seventh-day

Adventist Pastor . . . . . . . . . . . 42

Some Practical Suggestions . . . . . . . . . 45

Summary . . . . . . . . . . . . . . . 47 
TABLE OF CONTENTS (Continued)

\section{Chapter}

III. DEFINITIONS AND DISTINCTIONS, SIGNIFICANT OTHERS

IN THE SDA PASTOR'S WORK LIFE AND A VIEW TOWARDS NEGOTIATING AN INTENTIONAL MINISTRY . . . . . .

Definitions and Distinctions ... . . . . . . .

Creating a Role and Role Expectations . . . . . 51

A Look at the Seventh-day Adventist

Pastor's Role Set ... . . . . . . . . .

The Pastor's Wife and Family as

Significant Others . . . . . . . . . . .

The Local Congregation as Part of

the SDA Pastor's Role Set . . . . . . . . .

The Local Community as Part of the

Seventh-day Adventist Pastor's Role Set . . .

The Local and State Conference as Part of the

Seventh-day Adventist Pastor's Role Set . . . .

Concerning Role Conflict and Ambiguity . . . . . . .

Types of Conflict for the Pastor. . . . . . . 62

Towards Resolving the Local Pastor's Role

Conflict by Means of a Negotiated Ministry . . . . 66

The Basis of Negotiation . . . . . . . . 68

An intentional negotiation......... 68

Because the church is voluntary . . . . . . 69

Because the local church is heterogenous... . 70

To include the local church and conference. . . 70

Negotiation as an alternative to moving . . . 71

The Negotiating Process for the Local Pastor . . . 72

Openness of the pastor about himself . . . . 72

The pastor makes a self-assessment . . . . . 73

A self-study of the local church . . . . . . . 74

Develop a data-gathering instrument for the

local church ... . . . . . . . . . 75

Negotiate goals compatible to both pastor

and church................ . . 75

Concerning negotiation with the local

conference................

Sumnary .................... . . . 78

IV. A DESCRIPTION OF THE FOCAL PASTOR'S ROLE SET,

HIS POSITION, AND SELF-ASSESSMENT . . . . . . . . 80

Introduction . . . . . . . . . . . . . 80

A Description of the Grand Rapids Central

Seventh-day Adventist Pastor's Role Set ..... 80

The Church . . . . . . . . . . . . . 80

The City..................... 82 
TABLE OF CONTENTS (Continued)

\section{Chapter}

\section{IV. (Continued)}

The Conference . . . . . . . . . . . . 83

The Pastor's Position in the Conference

and in the Church . . . . . . . . . . . 86

A Time Study of the Position Involved . . . . . . 90

The Pastor as the Focal Person and Role

Receiver Identified . . . . . . . . . . 96

Concerning Self-examination . . . . . . . . . 97

A Brief Biographical Sketch . . . . . . . . . 99

Work Experience and Employment . . . . . . . . 100

The Writer's Theological and Working

Frame of Reference . . . . . . . . . . . . 100

Concerning the frequently moving pastor . . . 103

Personality and Vocational Profile

of the Focal Person . . . . . . . . . . 106

Tests involving personality . . . . . . . . 107

A test involving academic intelligence . . . . . 111

A test involving conflict management . . . . . 112

A test involving vocational preference . . . . . 115

Sumary .................. 118

V. THE RESPONSES OF GROUPS TO THE SURVEY AND AN

ATTEMPT TO ANALYZE THE RESPONSES TO SECTIONS

I AND VIII CONCERNING ADMINISTRATION AND TIME • •

An Analysis of the Responses of the

Subgroups to the Survey . . . . . . . . . .

Total Response................. 122

Responses from the Congregation . . . . . . . 123

Responses from the Conference Group . . . . . . 127

The Subgroups Identified . . . . . . . . . . 127

The Purpose and Plan of the Survey . . . . . . . . 129

Section I--Concerning Administrative and

Organizational Expectations of the Pastor . . . . 130

Concerning Organization and Administration . . . 130

Responses from the Survey . . . . . . . . . . 134

Leadership style . . . . . . . . . . . 134

Inner-church involvements . . . . . . . . 140

Involvements outside the local church . . . . 148

The pastor's administrative center. . . . . . 150

The pastor and public prayer .... . . . . 153

Summary ................... . . 154

Analysis of Section VIII--Concerning

Time Expectations of the Focal Pastor . . . . . 155

Summary .................... 163 
TABLE OF CONTENTS (Continued)

\section{Chapter}

VI. AN ANALYSIS OF THE RESPONSES TO THE SURVEY FORM CONCERNING THE TRADITIONAL EXPECTATIONS OF THE GRAND RAPIDS CENTRAL SDA PASTOR . . . . . . .

Section II--Concerning the Pastor's

Community Relations Expectations . . . . . . .

Responses Concerning the Pastor and Prestigious Persons . . . . . . . . . 168

The Pastor and the News Media . . . . . . . . 171

The Pastor and Civic Involvement . . . . . . . 173

Summary Concerning the Pastor and Community Relations . . . . . . . . . 175

Section III--Concerning the Pastor's

$\therefore$ Evangelistic and Outreach Expectations . . . . . . 177

Concerning the Conducting of

Public Evangelistic Meetings . . . . . . . 182

Concerning the Training of the Laity for Witnessing . . . . . . . . . . 183

A Summary Concerning Evangelistic and

Outreach Expectations of the Focal Pastor . . . 185

Section IV--Concerning Counseling and

Pastoral Visitation . . . . . . . . . . . 187

Analysis of Techniques and Resources for Counseling . . . . . . . . . . . . 190

Expectations of the Pastor in Times of the Crises of Sickness and Death . . . . . . . . 194

Analysis of Responses Concerning the Focal Pastor's Role in Times of Conflict... . . . 199

The Pastor's Visitation Program . . . . . . . 203

Counseling and Referral Expectations for the Focal Pastor . . . . . . . . . 206

Summary of Analysis of Responses Concerning

Pastoral Counseling and Visitation . . . . . 209

Section V--Analysis of Responses Concerning

Personal and Family Expectations . . . . . . . 210

An Analysis Concerning the Motivating Call of the Focal Pastor to the Ministry . . . . . 213

Expectations Concerning the Pastor's Devotional Life. . . . . . . . . 216

Responses Concerning the Competence of the Pastor 219

Responses Concerning the Pastor's Wife and Family 221

Responses to Expectations Concerning the Pastor's Social Life . . . . . . . . . 225

Summary of the Responses Concerning Personal and Family Expectations for the Focal Pastor . . . . . . . . . . 
TABLE OF CONTENTS (Continued)

\section{Chapter}

VI. (Continued)

Section VI--Analysis of Responses

Concerning Preaching and Worship. . . . . . .

Analysis of Responses Concerning the

Sermon and Sabbath Worship Service... . . . 233

Concerning the Pastor's Appeal in

His Sermons and Bible Studies . . . . . . . 237

The Analysis of the Responses Concerning the

Pastor's Role in the Prayer Meeting . . . . . 239

Summary of the Analysis of the Pastor's

Preaching and Worship Functions . : . . . . . 241

Section VII--Analysis of Responses

Concerning Teaching and Training . . . . . . . . 242

The Analysis of the Responses Concerning

the Pastor Teaching the Pastor's Bible Class : . 245

The Analysis of the Responses Concerning

Instruction for Baptismal Candidates . . . . . 245

An Analysis of the Responses Concerning

Witnessing Training for Laymen . . . . . . . 246

An Analysis of the Responses Concerning

Ministry for the Youth . . . . . . . . . . 247

Summary of Analysis Concerning

Teaching and Training . . . . . . . . . . . 249

Summary of the Analysis of the Responses

to the Survey Form . . . . . . . . . . . . . 249

VII. EVALUATION AND CONCLUSIONS . . . . . . . . . . 259

Concerns and Reflections . . . . . . . . . 259

New Approaches to Ministry are Acceptable . . . 260

Limitations to new approaches to SDA ministry . 261

This Project Reveals a Need for a

Negotiated-Type Ministry in the

Local Seventh-day Adventist Church . . . . . . 262

The Project Reveals that the Focal Pastor of

This Study may Experience Role Overload . . . . 263

Personal Goals--Assessment . . . . . . . . . . 265

Suggestions for Implementing a Negotiated Ministry 266

Positives and Negatives Concerning the Survey Form 269

An Enlarged Repertoire of Materials Con-

cerning the Pastoral Ministry ....... . 271

Personal Insights and Self-assessment . . . . 272 


\section{TABLE OF CONTENTS (Continued)}

Chapter

\section{APPENDICES}

A. Survey Form Used in This Study. . . . . . . . . . 275

B. Voluntary Comments and Suggestions by Respondents to the Survey . . . . . . . . . . 285

C. Letter of Instructions for Those Attending the Midwest Career Development Center . . . . . . 296

BIBLIOGRAPHY . . . . . . . . . . . . . . . . 298

VITA SHEET . . . . . . . . . . . . . . . . 306 
1. A twenty-five-day record of actual work time of the Grand Rapids Central SDA church pastor, January 8 to February 1, 1976 . . . .

2. Average hours of work per day of the Grand Rapids Central SDA church pastor . . . . . . .

3. A one-day breakdown of time spent in ministerial activities of the Grand Rapids Central SDA church pastor . . . . . . . . . . . . . .

4. Number of responses from the congregation and conference .................. 123

5. Responding laymen according to sex . . . . . . . . . 124

6. Responding laymen according to age . . . . . . . 125

7. Attendance patterns of responding laity . . . . . 126

8. Age range of conference committee members. and ministers . . . . . . . . . . . . 128

9. Identification and listing of subgroups . . . . . . . 128

10. Number and percentage of responses by congregation and ministers concerning the leadership style of the pastor of the Grand Rapids Central SDA church in reply to the statement: What leadership style is most acceptable?... . . . . . .

11. Number and percentage of responses by congregation and ministers concerning a successful ministry of the pastor of the Grand Rapids Central SDA church in reply to the statement: How will the pastor be most successful in setting objectives?

12. Median responses of the congregation, conference committee, and certain ministers concerning administrative and organizational expectations of the Grand Rapids Central SDA pastor . . . . . .

13. Number and percentage of responses by congregation, conference committee, and ministers in reply to the statement: The Grand Rapids Central SDA pastor should personally direct the Ingathering program . . . . . . . . . . . . . . . . .

14. Responses concerning the number of hours per week: the pastor of the Grand Rapids Central SDA church is expected to spend at his work . . .

15. Concerning the number of hours per week the respondents anticipate the Grand Rapids Central SDA church pastor spends at his work . . . . . . 


\section{LIST OF TABLES (Continued)}

Table

Page

16. Response of subgroups concerning the number of hours they each expect the Grand Rapids Central SDA church pastor to spend at his work each week. .

17. Response of subgroups concerning the number of hours they anticipate the Grand Rapids Central SDA church pastor spends at his work each week . .

18. Median responses of the congregation, conference committee, and certain ministers concerning community relations expectations of the Grand Rapids Central SDA pastor .............

19. Number and percentage of responses by congregation and ministers concerning involvement in civic affairs of the pastor of the Grand Rapids Central SDA church in reply to the statement: How should the pastor relate to national or community elections, social injustice and public controversies? . . . . . . . . . . . . . . . . . .

20. Median responses of the congregation, conference committee, and certain ministers concerning evangelistic and outreach expectations of the Grand Rapids Central SDA pastor . . . . . . . .

21. Number and percentage of responses by congregation and ministers concerning the pastoral counseling concepts of the pastor of the Grand Rapids Central SDA church in reply to the statement: What resources in counseling skills should the pastor use in his work? ... . . .

22. Number and percentage of responses by congregation and ministers concerning pastoral counseling methods of the pastor of the Grand Rapids Central SDA church in reply to the statement: What approach is best when counseling persons with personal or moral problems? . . . . . . . . . .

23. Median responses of the congregation, conference committee, and certain ministers concerning pastoral and visitation expectations of the Grand Rapids Central SDA pastor . . . . . . . .

24. Number and percentage of responses by congregation and ministers concerning conflict situations of the pastor of the Grand Rapids Central SDA church in reply to the statement: How may the pastor best help resolve conflict between church members and groups in the church? . . . . . . . 


\section{LIST OF TABLES (Continued)}

Table

Page

25. Number and percentage of responses by congregation and ministers concerning the motivating call to the ministry of the pastor of the Grand Rapids Central SDA church in reply to the statement: What should be the pastor's dominant motivation for ministry? . . . .

26. Median responses of the congregation, conference committee, and certain ministers concerning personal and family expectations of the Grand Rapids Central SDA pastor . . . . . . . . .

27. Median responses of the congregation, conference committee; and certain ministers concerning preaching and worship expectations of the Grand Rapids Central SDA pastor . . . . . . . .

28. Number and percentage of responses by congregation and ministers concerning sermon and Bible-study emphasis of the pastor of the Grand Rapids Central SDA church in reply to the statement: Should the pastor base his appeal upon the future or the present? . . . . . . . . . . . . . . . .

29. Median responses of the congregation, conference committee, and certain ministers concerning teaching and training expectations of the Grand Rapids Central SDA pastor . . . . . . . .

30. Summary of items which created significant disagreement between certain pairs of the subgroups based on Chi-square tests . . . . . .

\section{LIST OF FIGURE}

\section{Figure}

1. Four graphs concerning personal, interpersonal, small group, and intergroup conflict management by the focal pastor .............. 


\section{CHAPTER I}

\section{INTRODUCTION}

\section{The Justification of the Project}

The Seventh-day Adventist church was organized 114 years ago. There was much opposition among the believers to forming themselves into an organized church. One of the reasons was the fear by the general body of believers that they would lose their control and that some form of popery would develop or small groups could misuse the power placed in their hands.

Among the reasons for organizing was the desire to provide security for the leadership, particularly the ministers. Before the church was organized the ministers were in constant jeopardy of unpredictable livelihoods because they had to subsist upon direct donations from those they served. On the other hand, congregations were often preyed upon by unscrupulous, self-styled ministers. Without prior acquaintance, the local church groups had no way of knowing the credentials of these persons. Therefore, the organization provided those who served as ministers with identifying credentials and established a living wage pay scale that has been maintained throughout the ensuing decades.

Furthermore, church organization gave the Seventh-day Adventist minister some degree of security in his work-1ife within 
the church. He was under the direction of the head organization and his work was mainly evangelistic. There was very little emphasis upon pastoring the local church. The early Seventh-day Adventist minister's main purpose was to raise up churches and to develop evangelistic workers within the local congregations.

\section{Changes Since the Church was Organized}

The church has grown in numbers. The intervening years since the church was organized in 1863 has witnessed a multiplying of churches and institutions in all parts of the world. In 1863 there were approximately thirty-five hundred Seventh-day Adventists in the world. All lived in the United States and most resided in the rural areas of the Midwest and eastern part of the country. However, that picture has radically changed. Today the church boasts of a membership of nearly three million and has churches and institutions in 98 percent of the countries of the world. The great majority live and work in or near the urban centers. Very few Seventh-day Adventist churches may be found in rural settings today.

Furthermore, the local SDA congregation has increased in the average number of members..$^{1}$ A wide diversity has developed as to types of local churches. In size they range from small to large, both in numbers and in economic and personnel resources. The pastor is required to have a wide range of skills to serve such a variety of local needs in the churches. This has severe conflict implications for the local pastor.

${ }^{1}$ SDA is an abbreviation for Seventh-day Adventist used frequently throughout this study. 
The increased membership has made a highly developed organization necessary to maintain a unity of belief and practice. This requires organizational and management skills as well as pastoral, teaching, and evangelistic skills. Because of the large number of organizations within the church a considerable number of the working force is employed as administrators and other resource personnel rather than as pastors or evangelistic workers. Accordingly the pastoral-evangelistic ministry occupies only about 10 percent of the working personnel in the North American Division of the SDA church at the present time. A large number of the ordained ministry is employed in other than pastoral occupations within the church. It may be possible, therefore, that the importance of the local pastor's role has been subtly reduced in the eyes of many youth in training as well as among the laity.

Sociological and technological changes. In 1863 only about 10 percent of the population of the United States lived in the cities. Today about 80 percent live in the cities. The Seventh-day Adventist believers lived mostly in the country and most of the churches were in rural settings.

Considerable change has also taken place in science and technology since 1863. This has affected the work and life of the local SDA pastor as well. The mobile society and the instantaneous information media have reduced the impact of the pastor's traditional activities upon his parishioners. The scope of available knowledge on a wide range of subjects that is only indirectly related to one's spiritual needs has increased remarkably. While the pastor has 
benefited greatly in many ways, yet in many others the advanced technological knowledge has complicated his work. As one writer states so we11,

The new American culture has resulted in a change in what people expect of the minister. In the past the parish clergyman has performed his functions as a general practitioner. Now, increasingly, he is expected to be a specialist. 1

The advanced technological knowledge has led to a need of a more specialized approach to the ministry on the part of SDA pastors.

Finally, society itself has become more open and permissive.

Former taboos have been cast off. The "new morality," so called, has wrought havoc with many as far as their compliance with biblical principles is concerned. Simple truth and error appear to be difficult for many to discern. This has led to confusion over what is truth. According to Blizzard,

Parishioners who are confronted by a complex and chaotic world want to be counseled rather than receive a social call from the minister. They look for a perceptive prophet who is able to make sense out of the crisis of the current week rather than for a preacher who merely assures them that all is well with the world. 2

\section{Confusion About the Pastor's Function}

The pastoral office has always been of primary importance to God's earthly social system, the church. John Calvin strongly affirmed the importance of the local pastor by stating,

Not even the light and heat of the sun . . . not even is meat and drink, so necessary for the support and cherishing of our

${ }^{1}$ Samuel W. Blizzard, "The Minister's Dilemma," The Christian Century (25 April, 1956), p. 508.

2 Ibid. 
present 1ife, as the Apostolical and Pastoral office for the preservation of the church on earth. 1

The importance of the pastoral office has not diminished through the centuries. It is here to stay. While the pastoral office has maintained itself through the centuries it has had to adapt itself to the changing conditions of the world in which it serves. At times the office has been clearly defined. At other times it has been neglected, corrupted, misunderstood; it has been a source of frustration and even an obstacle to those seeking entrance to the kingdom of God. ${ }^{2}$

The term that seems to characterize those who write and discuss the life and work of the local pastor today is confusion. Many have verbally as well as orally expressed their confusion. In the mid-fifties Niebuhr wrote,

The contemporary church is confused about the nature of the ministry. Neither the ministry nor the schools that nurture them are guided by a clear cut, generally accepted conception of the ministry, though such an idea may be emerging. 3

Another writer on the subject is inclined to feel the current crisis stems from the question of the "identity" of the minister. He says,

The complaint is that the image of the ministry is cloudy, confused, and unattractive. Blame is assigned and the buck

${ }^{1}$ Charles Bridges, The Christian Ministry (London: The Banner of Truth Trust, 1830), p. 11 .

2Ellen G. White, The Great Controversy (Mountain View, Calif.: Pacific Press Publishing Association, 1911), p. 49.

3H. Richard Niebuhr, The Purpose of the Church and It's Ministry (New York: Harper and Brothers, 1956), p. 51. 
is passed from parish to pew, from seminary to college, from bishop to bureaucrat. 1

The negative effect of such confusion and buck passing and the conflict that it creates both upon the pastor as well as upon the congregation has been, at times, intolerable. National journals have published a number of articles to defend the actions of those who leave the parish ministry. They indicate that the greatest tension arises when the pastor finds his views concerning the role he is to fill incompatible with those of his parishioners. One bold ex-pastor advised, "Don't become a clergyman if you can possibly avoid it. No one really understands what the role should be, ought to be, or could be, Expectations are impossible to fulfill."2

Although most denominational authorities are reluctant to divulge just how many clergymen are leaving the parish ministry, it is evident that considerable numbers are doing so. What is pertinent to this study is the fact that some, at least, find the pastor's functions unclear, ambiguous, and difficult to fulfill. It is clear, also, that some would actually leave the pastoral ministry rather than to attempt to obtain a clearer concept of their role and develop ways of coping with the situation. The office itself is thus in jeopardy.

Of course, not all ex-pastors elect to go into secular work when they leave the parish ministry. A larger number elect to move

\section{${ }^{1}$ James Glasse, Profession: Minister (Nashville, Tenn.:} Abingdon Press, 1968), pp. 13-14.

${ }^{2}$ Gerald John Jud and others, Ex-Pastors: Why Men Leave the Parish Ministry (Philadelphia: The Pilgrim Press, 1970), p. 12. 
into another type of ministry within the denomination. This would be a normal experience for some. However, when the pastorate becomes only a stepping-stone to so-called higher specializations it loses some of its importance and challenge as a task worthy of receiving the best that one has to offer. That this mentality does exist among many who are in training is revealed by a recent study which states:

Two-thirds of 17,000 seminarians in 1962 reported that they eventually hoped to be in some type of ministry other than the parish. . . The large majority of seminarians are highly skeptical of or alienated from the concept of the parish ministry. 1

It is to be hoped that a more serious interest in the local pastor and church may be developing in the SDA denomination. ${ }^{2}$ However, little has been done to re-examine the work life of the local Seventh-day Adventist pastor. It is to this task that this study is devoted. It is an attempt by the writer to determine what a given congregation expects of its pastor. It attempts to compare the expectations of the pastor as seen by the local congregation and its subgroups with the expectations of the conference officials and certain ministers.

\section{The Task and Challenge of this Study}

The person who assumes the role as pastor of a local congregation must reckon with a number of factors that influence his

$1_{\text {Jeffrey K. Hadden, "Role Conflict and Crisis in the Churches," }}$ Ministry Studies, Nos. 3 and 4 (October/December, 1968), p. 24.

${ }^{2}$ General Conference of SDA, "Evangelism and Finishing God's Work," Review (2 December, 1976), p. 14. One of the goals of the new evangelistic thrust is to "clarify the role of the pastor." 
functions and activities in that role. He is influenced by his own understanding of his denominational and Christian heritage, by his study of theology, and by the community and local church traditions. As the "central figure in the ecclesiastical scene, [he] is asked to fill a role that is created for him by the expectations of his parishioners, the culture and the total community of which he is a part." 1

This means that the pastor is expected to comply, to some degree, to the expectations of significant others in his work Iife (i.e., his congregation, his conference officers and fellow ministers, his family, and community). It also means that certain adjustments will be necessary to every pastorate he serves.

To establish clearly defined role expectations in any pastorate the study must be done within a specific pastoral relationship. With the enlarged range of local SDA church situations today, one can no longer generalize concerning the functions of a local pastor. The need is to be specific concerning both the pastor and the congregation. Since every church is different and every pastor is different every new pastoral setting requires some type of negotiation between the pastor and his congregation. Expectations will vary from church to church. Therefore, if the pastor enters his ministry in the local church with the intention to negotiate with his congregation, an entirely new ministry should be created.

${ }^{1}$ S. Burkett Milner, "An Empirical Examination into the Ministerial Role Expectations of Clergy," (Ph.D. dissertation: Northwestern University, 1970), p. 3 . 
It should be compatible with both the pastor and his congregation. This is the model being suggested by this study. The result should be an intentionally negotiated ministry.

\section{Procedure and Methodology}

This study is an attempt to answer questions such as: How may a Seventh-day Adventist pastor become better acquainted with his own attitudes and preferences concerning his work life in the pastorate? How may he become more familiar with his congregation's attitudes, preferences, and expectations concerning his work life? To what degree does conflict exist, if any, between the congregation's attitudes and expectations and those of the conference officials and ministers?

The project evolved during the writer's tenure as pastor of the Grand Rapids, Michigan, Central Seventh-day Adventist church. As the result of a series of discussions with Dr. Arnold Kurtz, director of the Doctor of Ministry degree program at the Seventh-day Adventist Theological Seminary, it was decided to pursue this theme.

A two-pronged analysis seemed necessary to provide a model for the local pastor to follow. In order for the pastor to negotiate effectively with his congregation, both the pastor and his congregation must become familiar with themselves. They must know "who they are"; their strengths and weaknesses; their attitudes and preferences; their goals and ambitions for the ministry of God in that specific place and congregation.

To initiate the self-assessment process the writer as pastor attended the Midwest Career Development Center, Columbus, 
Qhio. This center is especially designed to help ministers determine their particular strengths and weaknesses, personal skills, and abilities. The personal insights gained are designed to make the pastor more able to negotiate his role with his congregation.

Also during this time it was decided a data-gathering instrument would be needed. ${ }^{1}$ This instrument was designed to obtain impressions of attitudes and preferences of the significant others who influence the pastor in his work life. These others include primarily the congregation, the conference officials, and fellow ministers. The arrangement and divisions of the instrument are described in greater detail in the early pages of chapter $\mathrm{V}$ of this study.

The subgroups were determined by age, sex, and attendance pattern, and different color questionnaires were administered to different groups comprising the significant others. Twelve different subgroups are included in the analysis of the responses. These are: less than twenty years old, twenty to forty-nine years old, fifty years old or older, attend less than every week, attend almost every week, male, female, officers and deacons, nonofficer laity, total laity, conference group, and the total sample.

Besides the frequency count and percentage of responses to each item on the questionnaire, two other tests were made concerning the responses. (1) The median point on the one to five scale in connection with items $1-69$, one to nine in connection with item 70 , and one to two in connection with items $71-78$ of the questionnaire 
was determined. (2) To determine whether certain pairs of subgroups agreed or disagreed significantly or not, the Chi-square test was applied. ${ }^{1}$ In this study disagreement is seen as significant if the probability percentage equals .10 or less in the Chi-square test. Also 1.000 is considered total agreement, between pairs of subgroups. Approximately five hundred forms were mailed, one to each member of the Grand Rapids Central SDA congregation, Michigan conference committee members, and a few former pastors and fellow ministers. A self-addressed stamped envelope was enclosed with each questionnaire for the return of the form to the pastor. No follow-up. letters or further contact was made with the groups except for one or two announcements made soon after the forms were mailed during the Sabbath worship service.

Further explanation of the procedure may be found at the beginning of chapter $\mathrm{V}$ of this study. Also chapter V and VI contain the summary of the total responses and an attempted analysis.

\section{The Limitations of this Study}

As stated above, this study is limited to a single church, the Grand Rapids Central Seventh-day Adventist church; to a single conference committee; and to a single pastor, the writer of this report. The main focus of this study is the pastor and the congregation. While the conference committee and certain ministers have been surveyed, it is not within the scope of this study to concentrate the discussion in their direction. The pastor is chiefly

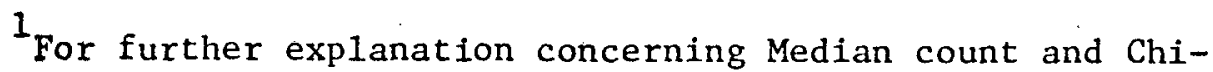
square testing see under definitions, pages 14-15 of this chapter.
} 
concerned with the negotiative model as it relates to the local congregation in this study. The conference group is treated as one of the twelve subgroups and the responses provide a means of comparison with other groups.

The model suggested by this study is more administrative than theological. The controlling norms of a negotiated ministry includes, therefore, administrative norms. However, certain theological concepts play an important part in the negotiation mode1. These include the pastor's theology of the laity, the church, and the ministry in general. The writer's theological position on these matters is based on the Bible and the writings of Ellen G. White. 1

The purpose of the study is to compare attitudes and preferences concerning the work life of a specific pastor in a local SDA church. The project was designed as a learning experience. As the study progressed it was found that certain items could have been omitted and certain others included. It being a pilot project, the conclusions reached may not be considered final.

This study was limited in that no interviews were conducted. Interviews may have proven helpful in obtaining even more specific attitudes and preferences. Also the pastor limited himself to only a few personality and other types of tests. Certain others may have been useful but will have to await further opportunity and available time.

\footnotetext{
${ }^{1}$ See chapter II, page 37 concerning the special influence
} of Ellen $G$. White on the work and life of the SDA minister. 
Not all of the data gathered over the past two years through the search of the 1iterature, questionnaire, and practical experience have been written up in this report. Considerable time may be needed and further comparisons made before all the insights may be gleaned from this survey. However, considerable knowledge has been gained that, properly adapted, may be used in a variety of ways to make the work of the local SDA pastor more efficient in his service for God and His cause.

\section{Objectives}

The thesis of this study is that there exists conflicting expectations between certain segments of the significant others in the local SDA pastor's work 1ife. As a result, the local pastor, therefore, may experience conflict within himself. It is the purpose of this research to design for the local pastor an intentionally negotiated ministry model for use in the local SDA pastorate. Within this concept the writer has the following objectives in mind:

1. To examine the position of the local Seventh-day Adventist pastor from a biblical and sociological perspective.

2. To become familiar with current literature on the 1ife and work of the local pastor.

3. To provide the local Grand Rapids Central congregation and the Michigan Conference administrators opportunity to observe the work expectations for the local pastor and thus obtain a clearer picture of the needs for that position. 
4. To present the findings of the project to the local church and to the Michigan Conference officers and/or committee at a time of their choosing.

5. To provide future pastors of this particular pastorate with information which could make their ministry more effective.

6. To present a suggested model that other pastors may use to reduce role overload, role conflict, and ambiguity within their pastoral setting.

7. To personally:

a. Develop skill in analyzing the needs of the local pastorate.

b. Obtain materials concerning principles of church leadership that may be shared with ministers both in training and in the field.

c. Gain a clearer insight to own strengths and weaknesses.

d. Make a mid-career self-assessment with a view to obtaining insight as to the choice of a specific ministry in the church.

\section{Definitions}

Chi-square test. The actual number of responses on a given item is compared with the expected number of responses. The expected number is determined by comparing the responses of one group with the responses of one or more other groups. The schematic formula is:

$$
\begin{aligned}
X^{2}=\Sigma \frac{(O-E)^{2}}{E} & \\
0 & =\text { observed frequency of response to an item } \\
E & =\text { expected frequency of response to an item } \\
\mathrm{df} & =\text { degrees of freedom }
\end{aligned}
$$


Conference. The official corporation of Seventh-day Adventist churches within a given geographical area, in this case, the Michigan Conference.

Focal church. The local church of this study, the Grand Rapids Central Seventh-day Adventist congregation.

Focal person. The local pastor of this study and the author. Median. The midpoint of an array, or the mid point between the highest and lowest of any given group in the sample.

Role. As used in this study, it refers to the position of the local SDA pastor and the various functions involved in that position.

Role conflict. Occurs when two or more roles interfere or contradict each other and make them difficult or nearly impossible to fulfill.

Role sender. Refers to anyone who has expectations of the pastor, in this study a parishioner to his pastor.

Role set. Collectively includes all those who influence the pastor in his work life or position.

\section{Overview of Study}

The remainder of this study will be dealt with in the following sequence:

1. The formulation of a theological basis for the local church as a center for ministry and a source of expectation for its religious leader. 
2. Role expectations and implications for the SDA pastor with a view to a new approach to an old problem: to negotiate an intentional ministry in the local church.

3. An analysis of a local SDA pastor's position functions, time utilization, and personal self-assessment.

4. A description of the survey instrument, organization of the subgroups, and the analysis of the responses to section I of the survey .

5. The analysis of the responses to the remaining sections of the questionnaire.

6. A suggestion of tentative conclusions based on the information gained through the research project and evaluated in terms of the benefit to the church locally and universally and to the author's personal ministry. 
CHAPTER II

THE LOCAL CHURCH AS A RELIGIOUS SOCIAL SYSTEM

In this chapter the local religious community, commonly known as the church, is discussed. Following a brief introduction, the chapter considers the church as a local congregation, as a voluntary society of believers, and as a religious social system having certain expectations both for itself and its leader. Also, there is a brief look at the origin and development of the Seventh-day Adventist religious movement as it exists today. Included with the discussion of the Seventh-day Adventist church is reference to certain special influences that affect the functions of the local pastor. The chapter closes with some observations concerning the SDA pastor's dilemma and some practical solutions.

\section{The Church as a Local Religious Unit}

It is at the local level that any movement meets the world outside. One may speak of the church two ways. He may refer to the local congregation in a given community or he may refer to the church universal. Both the local congregation and the universal religious movement exist simultaneously. The concern in this study is with the local religious unit which is the source of expectation for the functions of its leader. 
The local church at Jerusalem was the original center from which the gospel has spread to the world. This was in accordance with the design of Jesus Himself (Acts 1:8). The gospel was to spread from center to center until His return (Mt 10:43). Finally it was to go to all the world (Mt 24:14).

Following the stoning of Stephen the early Christian believers were "scattered abroad" and "went everywhere preaching the word" (Acts 8:4). Thus the movement spread from "Jerusalem to Judea, to Samaria, and unto the uttermost parts of the earth" (Acts $1: 8$ ). The great missionary travels of the Apostle Paul and his companions fathered churches into existence in certain specific cities and towns (Acts 14:20-28). Those who espoused the new Christian movement met on the Sabbath at specific places to pray and worship. (Acts 16:13; 18:4). Certain of these places became training centers from which missionaries were prepared to serve the movement (Acts 19:9, 10; Rom 16:1-15). There were local congregations in most of the major cities of Asia Minor and the Middle East by the end of the first. century (Rev $2: 1-29 ; 3: 1-22)$.

The word Ecclesia in Greek means a popular assembly or congregation and is used throughout the New Testament for the church. It may at times refer to the church universal as when Christ told Peter, "upon this rock I will build my church" (Mt 16:18). On the other hand it may refer to a local congregation as in Rom 16:5 where the Apostle urges his readers to "greet the church that is in their house." 
When Paul refers to the church as the bride and to Christ as the bridegroom he certainly must have been thinking of the local church at Ephesus as well as the church in general (Eph 5:22-32). John, the writer of the book of Revelation, pictures Christ among the candlesticks (Rev 1:20). These candlesticks symbolize the seven churches to which he addresses seven letters to the seven stars, or seven religious leaders, of these churches (Rev 1:20). One commentator says,

The divine Son of God is seen walking amid the seven golden candlesticks. Jesus Himself supplies the oil to these burning lamps. He it is that kindles the flame. "In Him was life and the life was the 1ight of men." John $1: 4$. No candlestick, no church, shines of itself. From Christ emanates all its light. . . The Lord God Almighty and the Lamb are the light thereof. 1

These seven churches to which the letters were addressed were local congregations then in existence. The messages were first applicable to these congregations and secondarily to the general church body.

When the Apostle Paul met Christ on the road to Damascus he was directed to the local church at Damascus for further instruction and counse1. In doing this Christ gave approval of the local congregational authority. What the human ministry could not do, Christ did for the Apostle designate: what the church could and should do, he urged them to do. Christ brought conviction and conversion but the local church was to instruct and baptize the newborn Christian, Paul (Acts $22: 10-16$ ).

IEllen G. White, The Faith I Live By (Washington, D.C.: Review and Herald Publishing Association, 1958), p. 280. 
The local church is a microcosm of the spiritual kingdom of

God. It is in the 1ocal congregation that the "Kingdom of God confronts the individual." 1 To refer to the church as existing only in general terms but without particularity may serve to weaken the effect of the kingdom of God where it confronts the individual. The human tendency seems to generalize and spiritualize rather than to particularize, as one writer observes,

In our great concern for the spiritual kingdom, it is possible to lose the significance of the local church. Emphasis on the spiritual body may at times become too idealistic. The utopian "city of God". can never be realized on a grand scale while the local church is neglected. 2

At least one New Testament scholar believes that the first local congregations of the early Christian church had but few if any public meeting places of their own. ${ }^{3}$ Metzger cites the fact that "history leaves no record of any distinctively set-apart church building in the first and second centuries" is proof that little emphasis was placed by the early Christians on meeting places as such. Rather the believers met mostly in homes of the believers. For example, prayer was offered for Peter at the home of John Mark In Jerusalem (Acts $12: 12$ ). It is 1ikely that this was only one of the many "house churches" in Jerusalem at the time.

${ }^{1}$ Franklin M. Segler, A Theology of Church and Ministry (Nashville, Tenn.: Broadman Press, 1960), p. 13.

2 Ibid., p. 14 .

3 Bruce M. Metzger, "The Evolution of Organization in the Early Church," paper presented at the Day-Higginbotham Lectures, Southwestern Baptist Theological Seminary, Ft. Worth, Texas, 14 February, 1974 . 
As the synagogues closed to the apostle Paul and others because of prejudice on the part of the Jews, the believers opened their homes to make them the religious centers for the Christians. Priscilla and Aquilla made their home available for fellowship and study (1 Cor 16:19). A woman named Nymphas at Laodicea was hostess to a group of believers (Col $1: 15)$. Philemon of the city of Colossae made his home available as a meeting place also for a group of disciples (Phm 2).

There appears to be little in the nature of a formal organization in the early Christian church revealed in the book of Acts. Perhaps the informal atmosphere of the house church made a highly organized Christian movement less important. Also it appears that the believers shared the leadership roles which meant that all functioned in some form of ministry (Rom 12:7). How, then, did the special leadership known today as the "pastor" develop? An attempt will be made to answer this question.

\section{A Leadership of Necessity}

The scriptures indicate that a11 who believe and follow Jesus Christ become priests of God (1 Pe 2:9). As disciples and priests of God every believer has certain ministerial responsibilities. Anyone desiring to lead was encouraged to do so but he was always to be in a "servant of al1" attitude (Mk 9:35).

Since the priesthood of the believers makes every believer a potential priest, the pastor labors as a minister among other ministers. He is chosen for the "high purpose of service to God and humanity. All of them, by whatever terms they were 
designated--elders, deacons, bishops--shared a common ministry. Any division of labor was a matter of practical necessity and not of ecclesiastical office."1

The very nature of the rising religious movement in the early Christian church required human leadership. Yet this leadership must recognize their total dependence upon the true Leader, Jesus Christ. Activities requiring human leadership included prayer and ministry of the word (Acts 6:4); caring for the poor (Gal 2:10); baptising (Mt 28:18, 19); conducting the communion service (Acts 20:7). Also the administering of certain rites for the sick (Jas $5: 13$ ), the ordaining of deacons (Acts 13:3), and the maintaining of certain standards of conduct fell upon the leadership of the early church. An authentic source states:

The discharge of all those duties led to the emergence of special persons to perform them. Christ himself had chosen certain ones to continue his work (Matt. 28:18-20) and the title, Apostle, which he had given them (Luke 6:13) could be conferred by the Christian Community, (Ga1. 1:1). . . O Other designations were also used; Ruler, (Rom. 12:8; Heb. 13:7, 17, 24); Elder, (Acts 11:30; 14:23; James 5:4); Bishop, (Phil. 1:1); Prophet, (Acts 11:27); Teacher, (Acts 13:1); Evangelist, (Acts 21:8); Servant, (Phil. 1:1).2

The necessity for special persons to function in these capacities led the early church to select from "among the people" those who should serve. The leaders were chosen from their own membership "in order that direction may be given to the combined activities of

${ }^{1}$ Segler, A Theology of Church and Ministry, pp. 57, 58.'

2 The New Schaff-Herzog Encyclopedia of Religious Knowledge, s.v. "Practical Theology," by W. Caspari. 
the congregation. - . Whatever pre-eminence came to leaders came

as a result of their service." ${ }^{1}$ Segler continues,

A ministry of servants, recognized for the services they rendered rather than for the position they occupied, represents the purest forms of the ministry in the early church. This is the only form of ministry which is consonant with the essential character of Christian faith. ${ }^{2}$

These principles are affirmed by other writers as well:

The position or office a man may hold is not alone an indication of his usefulness in the cause of God. It is the development of a Christlike character through sanctification of the spirit that will give him influence for good. In the estimation of God the degree of his faithfulness determines the value of his service. 3

The pastoral role, along with others, is referred to as a Spiritual Gift (Eph 4:8-11). These gifts, apostles, prophets, evangelists, pastors and teachers, appear to be complimentary and not mutually exclusive. At times the prophet may function as an evangelist or pastor, or teacher, but his main forte is prophesying. The pastor may, at times, function as a prophet or teacher or evangelist, but his main forte is pastoring. In the early church the religious leader often functioned in many of these roles. However, as the church grew in numbers it became necessary to develop a plurality of ministers in the church.

It appears that at the beginning of the church's existence the believers considered themselves a brotherhood. However by the

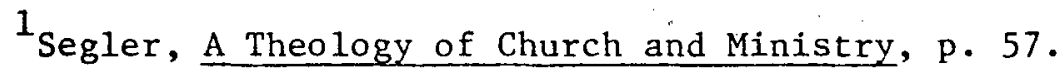

2 Ibid., p. 62 .

${ }^{3}$ White, Selected Messages, $1: 186$. 
end of the fourth or fifth century a highly developed hierarchical organization was in existence. ${ }^{1}$. Also,

By the fourth century there had developed a great divide between the clergy, on the one hand, and the laity on the other. . . The earliest Christians took as a name for themselves, from the terminology of the 01d Testament, the expression "people of God," in Greek, laos tou Theou. But in the course of time, the noun laos, meaning "people," came to be applied in the adjectival form, laikos, to designate those members of the church that we today would call the "laity," those members who had not been ordained.

Thus, for good or ill the church became highly organized with various levels of leadership. The human thirst for power may still be partially responsible for the heirarchical nature of the organization (Mk 9:34).

Although there is no direct New Testament evidence, it is speculated that the head of the house where the Christian believers gathered could have acted as the local pastor or elder for that group. His being able to entertain a group of this type may indicate his position and his attainments. Such may have made him capable of serving in such a leadership role.

What has been discussed thus far can be summarized briefly as follows: (1) there appears to be little doubt but that in the early Christian church the local religious unit was centered in the homes of the believers rather than in public buildings, as it is today; (2) it is evident that leadership was necessary for the purpose of directing the "Saints in serviceableness" (Eph 4:11, 12); and (3) it is possible that the position of local pastor was filled

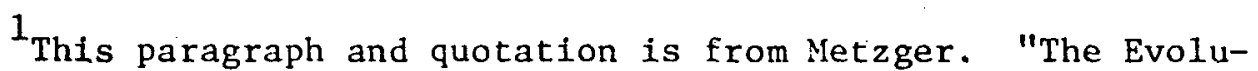
tion of Organization in the Early Church," p. 1. 
by the owner or head of the house where the believers met. In the early period, at least, the local church was an informal organization more familylike than it appears to be today. The expectations of the leader may have been similar to what one expects of the head of a home--integrity, courage, love, faithfulness, and so forth.

How is the local and the universal church different from other organizations in the world today? What motivates the adherents to devotion, loyalty, and service? These questions will be dealt with in the following section of this chapter.

\section{The Church is Voluntary}

According to the apostle Peter the newly baptized member of the local church becomes a "priest" in his own right (1 Pe 2:5,9). He is authorized to act as an intercessor for those needing special help ( 1 Ti 2:1). Thus each individual is free to act as God directs him in behalf of himself and the salvation of others (Gal 5:13). He is to use his gifts as he has ability to help build up the kingdom of God ( 1 Cor 12:4-31). The organized church is to build priests and thus edify the whole body.

This freedom stemming from the "holy priesthood" of believers creates a voluntary situation within the church. Those who espouse the Christian church do so on the basis of the voluntary principle. Each worships God "according to the dictates of his own conscience." There is no coercion, no external force. The conviction must exude from within.

In the early beginnings of the Christian church, the New Testament indicates that those who followed Jesus Christ did so on 
a voluntary basis. The words "whosoever" and "whosoever will" in In 3:16 and Rev 22:17 indicate that God leaves the choice with the will of the individual. Those who united with the church did so of their own free will. No earthly government fostered, supported, or sympathized with the new movement. Instead the church faced an unfriendly social and political system. Persecution was common. Those who united with the movement did so voluntarily, often at the risk of their own lives.

Basic to the voluntary church is the fact that salvation itself is voluntary. There is no coercion, no forcing, no authoritarian compulsion.

Jesus is the ultimate volunteer. In heaven before the world was created, He willingly volunteered to become the Saviour of mankind (Eph 1:4). The plan of salvation was laid before the creation of the earth. Christ is "The Lamb slain from the foundation of the world" (Rev 13:8). A classic passage describing his condescension is found in Php 2:6-8. Jesus provides the church and its leader the ultimate motive for voluntary service.

Those who unite with the church become a part of a specific group of volunteers. As John Owen stated in the seventeenth century,

The church is a voluntary society in which persons otherwise absolutely free.. . do of their own free wills coalesce into it. . . . Herein neither by prescription, nor tradition, nor succession, hath any one more power than another but they are all equal. 1

What holds the voluntary system together? In what way must the leader function differently in such a system?. An attempt will

${ }^{1}$ Segler, A Theology of Church and Ministry, p. 10. 
be made to answer these and other questions that may occur in the next section of this chapter.

\section{The Church as a Voluntary Religious Social System}

There is no doubt that the Christian church is religious; without doubt the church is voluntary; but, also, the church is a social system. What is a social system? To answer this question it is necessary to consult the sociological field. One source should suffice.

A social system is described by Bertrand as "two or more people in interaction directed toward a goal and guided by patterns of structured and shared symbols and expectations." 1 The same author defines a religious social system as "socially sanctioned groupings of persons united together by a set of mutually shared beliefs and practices relative to the nonempirical world, who interact according to well-defined roles. 2

Pertinent to this study is the fact that the local church qualifies as a social system based on the description and definition given above. The local church must have two or more persons; it has a mutually agreed upon goal; it has mutually agreed upon beliefs and practices concerning faith and eternity; and, there are specific rcle demands made between member and member and between member and leader.

${ }^{1}$ Basic Sociology, p. 25, quoted in S. Burkett Milner, "An Empirical Examination into the Ministerial Role Expectations of Clergy," (Ph.D. dissertation, Northwestern University, 1970), p. 34.

2 Ibid., p. 35. 
The Forces that Bind the System Together

Any religious social system must have mutually agreed upon beliefs and practices that are expected of all its adherents. These expectations serve to bind the members together in the system. Once a person volunteers and accepts the beliefs and practices as the norm for his life, he becomes a part of the religious social system.

A further clue as to what holds the system together may be found in what would cause the system's demise. Milner states that only one of three conditions need arise to cause the disintegration of any social system: (1) apathy of the members, (2) dispersion of the members, and (3) war of expectations. ${ }^{1}$

While a certain amount of apathy may be expected within any social system, it must not exceed a certain level. There must be enough involvement to maintain the system. Likewise to destroy a social system by dispersion only a certain number need leave to collapse the system. Only enough of the adherents need remove themselves to weaken the structure and render inoperative its system of shared expectations and cause its demise. The "war of expectations" in the social system takes place when each member holds different expectations for a given position. Milner states, "The religious social system would terminate if each member or each congregation held widely varying expectations for the religious leader." ${ }^{2}$

In order to perpetuate the religious social system, the church, certain prerequisites are necessary. These, according to Milner, are, 
(1) recruitment or converting individuals into church members,

role-differentiation and role-assignment, (3) communication, and (4) socialization. ${ }^{1}$

Recruitment involves the outreach of the religious social system. According to Milner,

Recruitment may be a problem for the religious leader because in order to maintain the old members! commitment, it may be necessary to make every effort to satisfy their needs. Yet this may frustrate the minister from successfully recruiting new members whose needs are different. 2

The role-differentiation and role-assignment prerequisites

involve the various activities necessary in making the social system function. Milner states that certain

Activities must be regularly performed if the system is to persist. . . These activities must be broken down and assigned to individuals trained and motivated to carry them out. Otherwise everyone would be doing everything or nothing which is the antithesis of shared expectations in a social system. 3

In communicating its message the religious social system utilizes both oral and written communication, as well as other means to inform others concerning its expectations.

Socialization is the process by which new members of a social system become oriented to the values and norms of the system. While the new member may not be "familiar with all aspects of his society, he must have a working knowledge of the behavior and attitudes. relevant to his roles plus identify to some degree with such values as are shared by the whole system." ${ }^{4}$ The socialization process

${ }^{1}$ Ibid., p. 37.

3 Ibid.
${ }^{2}$ Ibid., p. 38.

${ }^{4}$ Ibid. 
begins the moment one attaches himself to any social system. In the religious social system it actually begins before he unites with the church and continues for some time after he has joined. "A system cannot persist unless it perpetuates a shared set of expectations. This is the function of socialization."1

To briefly summarize, firstly, the local church functions as a social system in that the members hold to mutually agreed upon beliefs and practices. These beliefs and practices impose certain demands or expectations upon each of the members of the system. Secondly, as long as new members are recruited, role assignments are being filled, communication exists both within and without, and socialization takes place, the system will survive. Thirdly, socialization is the process by which a new member or leader imbibes the beliefs and practices, or social peculiarities, of the system. The new member or leader identifies with the values of the system. This socialization process may take time, but if it continues the person eventually "owns" the system.

Since the church is a voluntary religious social system and the concern in this study is with not only the system but also the leader of the system, it is necessary to know how the leader is affected. It is to this matter the next section of this chapter is directed.

\section{Expectations of the Leader within a Voluntary Religious Social System}

The Volunteer Servant

Once a new member or a new leader becomes a part of the voluntary religious system, the local church, he immediately subjects 
himself to certain role expectations. These may not be clearly de-

fined at first. It may require a considerable period to learn a11 that is expected.

The leader, as we11 as the follower, in the voluntary

religious system is to be first of all a volunteer. He may, however, be recognized as possessing special skills. His first qualification

is that he has a compelling desire to serve on a voluntary basis. He is part of the "Royal priesthood" ( $1 \mathrm{Pe} 2: 5,9$ ) and functions first in that capacity. He is qualified more for his desire to serve than any other: He reflects, to some degree, his Lord's motive for service. He henceforth lives in what Moulton describes as the "land of obedience to the unenforceable. "1

The Blessings and Curses of Voluntaryism

Voluntaryism has been a blessing to the Christian church in America in that the individual has been more highly motivated than in the state church system of the postreformation period. Some Europeans questioned the wisdom of total voluntaryism in religious matters as it is in America. Questions such as,

What would be the fate of churches which were entirely" dependent upon voluntary support? How would churches be built, salaries paid? What powers would ministers have who were dependent upon the congregation they served for financial support? What concept of the church would emerge from this conglomeration of voluntary associations? ${ }^{2}$

$1_{\text {Eva and Ronald Lippitt, Rainman-Schindler, The Volunteer }}$ Community (Washington, D.C.: Center for a Voluntary Society, 1971), Introductory page.

2 Milton Powe11, ed., The Voluntary Church (New York: The Macmillan Company, 1967), pp. XIV, XVI. 
The degree of success of the voluntary church experiment in America is now a matter of history. The church did not wither away. The Christian religion has survived in the matrix of voluntaryism.

When it comes to the local church and its leader there are both blessings and curses to voluntaryism. The blessings are almost self-evident. There is freedom to choose one's religious preference or choose no religious preference. One's motives as to the religious course he takes may not be so easily questioned in a voluntary system. Those who volunteer may serve from a higher motive than simple duty, compulsion, or conformity. It thus serves to develop a higher degree of devotion than a non-voluntary system.

On the other hand many may see in voluntaryism a "take it or leave it" attitude as far as religion is concerned. It may reflect itself in a superficial approach to religion. Christianity is only one option among many and therefore total commitment is absent to any certain faith. As stated by one writer:

Today, attendance, amount of financial support, and the intensity of adherence to the doctrines and goals of a particular religious group are, to a large extent voluntary and private decisions. If an individual strongly objects to some aspect of the particular religious group to which he belongs he is free to join another religious group or withdraw from participation in a religious group altogether. 1

The implications for the religious leader are impressive from the statement quoted above. The very nature of the church as a voluntary religious system may be a source of conflict for him. If the system has no mutually agreed upon central motivating force,

${ }^{1}$ Jeffrey K. Hadden, "Role Conflict and Crisis in the Churches," Ministry Studies 2 (December 1968):21. 
purpose, or goal, and no central authority except the personal whims of its members, then leadership conflict will result. The leader will live in the constant tension between "playing to his audience" and his own inner convictions. The voluntary nature of the system may thus become a curse to the leader. The leader may take two or more courses. He may identify totally with the religious social system to the extent that he "owns" it, or he may resist and pursue an independent course of his own choosing. However, there are other courses he may pursue such as the one suggested in this study, negotiate with his religious system an intentional ministry. Of course, he also has the privilege of resigning as well.

\section{Socialization and Voluntaryism}

The church pastor is influenced by expectations of his parishioners, the culture and community of which he is a part, plus his own denominational traditions and his study of theology. If he began as a volunteer he must now act professionally. According to Milner, there is an important relationship between the occupation, the individual's conception of that occupation, and his total identity as a person. ${ }^{1}$ Everyone is influenced in his total personality by the occupation he pursues. One develops his role conception by obtaining the norms and values that exist between himself and other members in the same occupation and the relationship of that occupation to other occupations. $^{2}$

\footnotetext{
Milner, "Ministerial Role Expectations of Clergy," p. 39. 2 Ibid.
} 
One may say, "I am the pastor of a certain church." In saying this he sets himself apart from all other occupations and all other denominations and congregations. He is identifying himself with the social matrix of that particular congregation. Hopefully, he is sufficiently socialized that he can speak positively as if it were his own. If so, he "owns" the system. If not he may have conflict. If the role he is filling in that particular place meets his selfconception socially as well as theologically, he is likely to be quite contented.

According to Milner, Vidich and Bensman found that a "minister's behaviour is shaped by his outside connections, training, background, and denominational ties."1 They found that,

In time, 'the congregation and the community socialize the minister to local values, but they were not equally successful in Springdale. The authors partly attribute the high turnover among Springdale's ministers to the disparity in values between church members and ministers. 2

In their report of this study the authors list the criteria for a good minister based on Springdale's expectations. They found that, "The minister's personality overrides in importance all theological and policy considerations." 3

What has been stated concerning the leader of the voluntary religious social system can be summarized by emphasizing the following points: (1) The leader himself must be a volunteer. He has for his model the Lord Jesus Christ who was the ultimate volunteer.

(2) Voluntaryism in the religious world has proven itself viable, but there are certain problems that it creates for the local pastor

$$
{ }^{1} \text { Ibid., p. 13. } \quad{ }^{2} \text { Ibid., p. 14. } \quad 3 \text { Ibid. }
$$


of a Christian church. He may find himself in the midst of a "war of expectations" either between himself and his congregation or judiciary, or he may be caught in the crossfire of expectations between certain subgroups within the system. (3) The pastor may choose one of several courses to resolve his conflict. He may resign; he may lose his own identity within the system; or, he may negotiate with the system. Whatever course he may pursue he must expect to become socialized to some degree to the social system of which he is the leader.

To determine his performance the pastor in the religious social system must consider his own self image, his expectations of himself in that role, and the expectations of significant others for whom or to whom he may be accountable. If there is any discrepancy between these "publics" there is likely to be conflict and dissatisfaction between the publics and the pastor or between the publics themselves. The religious leader has his own self-concepts and theological groundings to mesh with those of his parishioners in the socializing process. How may this be done? To partially answer this question a look at a more specific voluntary religious social system, the Seventh-day Adventist church, will now be taken.

The Local Seventh-day Adventist Church as a Religious Social System

The Seventh-day Adventist movement arose from obscurity and spread around the world during the middle and late nineteenth and early twentieth century. Many of the early pioneers of the movement were untrained laymen who had been followers of the Millerite 
movement of the late 1830s. William Miller, a self-taught layman, sparked a revival of interest in the approaching end of the world by basing his preaching on the prophecies of Daniel, chapters 8 and 9. Thousands were aroused from their complacency and fled their. churches to join the movement. From his own calculations based on the 2300 day-year prophecy of Dan 8:14, Miller predicted that Christ would come sometime during the year 1843 or 1844 . However, the movement was doomed to disappointment. When Christ failed to come as predicted many of the followers abandoned their belief and returned to their previous ways. Some of those who remained through prayer, study of the Bible, and special insight arrived at what is now known as the Seventh-day Adventist movement.

Basing their message on Rev 14:6-12, the Seventh-day Adventist Church claims to be the last full-gospel Christian movement that will usher in the coming of Jesus and the end of the world. Their adherence to "the commandments of God and the testimony of Jesus" (Rev 12:17) identifies them with the "remnant" of the true church of all ages. Their goal is to follow strictly the Bible as their rule of faith and practice and demonstrate primitive godliness which characterized the early Christian church. The Lord Jesus Christ is the central figure and His love the motivating force.

The Seventh-day Adventist church fulfills all the qualities of a voluntary religious social system. Mutually shared beliefs and practices are at a high level. Membership is on a voluntary basis and expectations are clearly delineated prior to being taken into the fellowship. The system has existed over a period of time 
and has a clearly stated goal. The priesthood of the believer is clearly accepted and taught. The pastor's role expectations are theologically clear. There is little ambiguity concerning the nature and purpose of the church.

One might conclude from the ideal conditions stated above that little confusion, ambiguity, or conflict exists concerning the role of the pastor in the Seventh-day Adventist church. However, one can see that a definite "war of expectations" has developed that is affecting the onward progress of the movement. Numerous local church congregations are static in their growth pattern both numerically and spiritually. ${ }^{1}$ Many pastors are frustrated and unable to meet their own or their congregation's expectations. Certain elements that have led to this condition must be examined before a possible solution is suggested.

The Special Influence of Ellen G. White

Unique to the Seventh-day Adventist movement is the life and work of one who served the church as a lay-person all her life, Ellen G. White. Fulfilling the role as a modern Messenger of God, Mrs. White gave invaluable counsel and guidance in the development and organization of the Seventh-day Adventist church. As one of the most prolific writers of all time, one cannot think of any aspect of the movement that has escaped her pen.

${ }^{1}$ Gottfried Oosterwal, Patterns of SDA Church Growth in North America (Berrien Springs, Michigan: Andrews University Press, 1976), pp. 17-62. 
E11en White received her first vision at the age of seventeen years in December of 1844. During her remaining seventy years she served the Lord and her church and received two thousand such visions and revelations from God. Her writings include some sixty printed volumes plus 4,500 articles in church periodicals.

Most of the written material from Ellen White was produced during the latter half of the nineteenth century. This was during the formative stages of the development of the Seventh-day Adventist church. Her testimonies for the church, therefore, were given at a time when specific crises arose or new light was shed as to procedures of operation of the church or life-style. These counsels have been of invaluable benefit to the church social system as a means of establishing mutual expectations between members of the system. The Seventh-day Adventist church thus shares a religious unity not found in many religious circles today.

Counsel and guidance concerning the expectations of the Seventh-day Adventist pastor appears in great abundance in the written works of Ellen G. White. In the comprehensive index to her writings, no less than forty-seven pages of references may be found concerning the minister, the ministry, or the pastor. The writings also provide the pastor a rich source of theological guidance concerning his role expectations in the church.

While the writings of Ellen G. White are not designed to supersede the Bible, they are considered inspired of God by the Seventh-day Adventist church. Thus, along with the Bible, these writings provide the major source of shared expectations within the entire denomination. 
Because of the high esteem these writings hold in the minds of both laity and ministry. in the Seventh-day Adventist church, there is much agreement between them concerning the minister's function in the church. There is also a unity of belief and practice in the SDA church that one does not find in most religious movements of its size today. Even though the pastor may have a conflict of expectations it is not likely to be caused by a crisis in "belief and practice" as is the case in some religious movements today. 1

The Seventh-day Adventist pastor, therefore, may be said to stand on vantage ground in determining his expectations in the church. Besides the Bible he has this unique source of highly esteemed counse1. Although much of the counsel concerning the expectations of the local pastor is of a general nature, there is much of a specific nature that applies to the local pastor. Reference has been and will be made in this study to this source as a chief source of counsel for the pastor and his religious social system concerning the expectations of the pastor.

Organization and Development of the Seventh-day Adventist Church

Many in the new movement were reluctant to develop an organizational structure in the church. They feared popery might result with all its dire consequences. However, the need for organization became more and more evident as the movement grew in numbers and

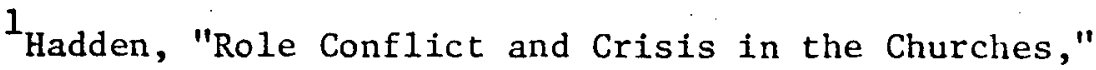
Ministry Studies, December 1968, p. 16. 
possessions. As the result of constant urging by leading ministers and Ellen G. White the movement organized in 1863 under the name Seventh-day Adventist church. After considerable discussion and examining of the scriptures the type of organization chosen was

Representative--the form of church government which recognizes that authority rests in the church membership, with executive responsibility delegated to representative bodies and officers for the governing of the church. This form of church government recognizes also the equality of the ordination of the entire ministry.1

The local church is "a united body of individual believers." ${ }^{2}$

Four other organizations complete the denominational structure:

(1) the local conference or local mission, a united body of churches in a State, province, or local territory; (2) the union conference or union mission, a united body of conferences or mission fields within a larger territory; (3) the division, a section of the General Conference embracing local or union conferences or missions in large areas of the world field; and (4) the General Conference, the general body embracing the church in all parts of the world. 3

Ellen G. White fully endorsed this plan and structure.

Every member of the church has a voice in choosing officers of the church. The church chooses the officers of the state conferences. Delegates chosen by the state conferences choose the officers of the union conferences; and delegates chosen by the union conferences choose the officers of the General

Conference. By this arrangement, every conference, every institution, every church, and every individual, either directly or through representatives, has a voice in the election of the men who bear the chief responsibilities in the General Conference.

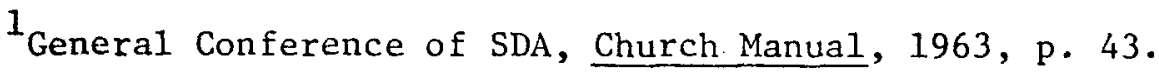

2 Ibid., p. 44 . 3 Ibid., p. 45.

${ }^{4}$ Ellen $G$. White, Testimonies for the Church, 9 vols. (Mountain View, Calif.: Pacific Press Pub. Co., 1948), 8:236. 
In theory and practice the organization has proven most effective through the decades since its implementation. Advantages outweigh the disadvantages. The clergy are fairly and regularly paid from the conference level. Each local church is treated on an equal par with another. Pastoral assignments are made by the administrative officers and central committee of the local conference on the basis of need and available personnel. A great deal of authority resides in the local conference officers and the central committee in the Seventh-day Adventist denomination. This places grave responsibility on those in charge of the local conferences.

The Local Seventh-day Adventist Church Today

When the SDA movement was in its early stages of development and the numbers were small, the local church wielded greater control over its own program than today. But with the coming of centralized authority in the local conferences considerable change has taken place as to the influence of the local congregation over its own program. In theory there should actually be little change in the voice of the local church, but practically one realizes that human weakness tends to create difficulty in applying the principle that, in the words of the church manual, "authority resides in the church membership." The human tendency seems to be to generalize and to centralize authority organizationally rather than theologically; to center activities at another place than where "the kingdom of God confronts the individual," the local church; to measure the church's success on criteria established by those not directly involved in 
the local setting. These tendencies, though human, seem to be affecting the onward progress of the church in its mission to the local communties of America.

The above-mentioned tendencies seem to be a factor in the growth of the church as shown in a recent study conducted in a number of local SDA churches. ${ }^{1}$ The study reveals that many local SDA congregations suffer from a lack of growth both numerically and spiritually at a time when growth would normally be expected. 2

The author of the report states:

Two things proved to be fatal to a large and rapid church growth in the many churches that make up the Adventist constituency: 1) Local churches have become too dependent for their growth in every dimension on the central organization. . . . 2) In the central planning of programs and activities far too little consideration has been given to the immense diversity of SDA believers and churches. . . . Unless conferences and departments build into their programs a large measure of local initiative, creativity and internal motivation, based on the particular gifts and resources available in the congregations, participation will remain at a minimum and churches will not grow. 3

The human tendency to generalize rather than to particularize

is seen here. It seems to have had its effect in the organizational structure of the Seventh-day Adventist church. This has especially had some influence on the expectations of the local church pastor which has implications for this study.

Implications for the Local Seventh-day Adventist Pastor

Only by careful balance between his theological orientation and the organizational framework of the church is the local SDA pastor

10osterwal, Patterns of SDA Church Growth, pp. 17-62.

${ }^{2}$ Ibid.

${ }^{3}$ Ibid., p. 66. 
able to avoid becoming just an organizational man. It would be easy to fulfill his expectations only as they pertain to the conference level. He might assume that he is employed by the conference and not by the local church of which he is the pastor. He might tend to be more influenced by his organizational superiors in his work life and in his decisions than by his personal theological convictions based on Jesus Christ.

In the SDA church-growth report cited above, it was found that among both laymembers and pastors in the Seventh-day Adventist churches there is an awareness that great improvement is needed and that frustration is being experienced by both pastors and laymen. Both members and ministers felt they were doing a poor job in stimulating church growth. The members, perhaps unfairly, were critical of the ministers for their poor leadership in teaching, preaching, pastoral care (visitation), lay-training programs, and personal guidance. ${ }^{1}$ Almost all ministers felt they would like to spend more time doing these things, but they are so busy with all the other affairs of the church, that they have no other choice but to neglect or to de-emphasize the work which they would like to do, what they felt they were called to do, and that the members most wanted them to do. 2

Furthermore, the report states that these ministers spent 50-60 percent of their time "performing administrative duties of the church, the promotion of projects and programs coming from the conference and the union, the care of finances, the church school,

$$
{ }^{1} \text { Ibid., p. } 67 . \quad{ }^{2} \text { Ibid. }
$$


board meetings and the like." 1 Another $20-40$ percent of thelír time was spent doing pastoral care duties. This left only 10-15 percent of their time for the work which they considered most essential, stimulating church growth through evangelistic outreach. Precious little of his time could be given to serious study.

In fact, a large majority of ministers indicated that they had not done any serious studying since they left college or the seminary. And nearly all felt that their personal devotions, sleep and exercise and time spent with the family were grossly neglected. ${ }^{2}$

The multi-faceted role of the local pastor is well known. It may even be more so for the Seventh-day Adventist pastor than some others. He wears many hats. The Seventh-day Adventist minister's manual states, "Upon him (the minister) rests the responsibility of overseeing and fostering all branches of the work.. he should familiarize himself with the methods of organizing and carrying on all these church activities." ${ }^{3}$ The question confronting him is whether he is to perform equally well in all these many functions or whether he should not; and if not what alternative does he have. Can the local SDA pastor change his role relationships so that he is able to function in harmony with himself and those to and for whom he is responsible? If he is caught in the crossfire in a "war of expectations," what must happen if he is to be preserved? Is it possible that the situation may be changed? Seventh-day Adventist pastors apparently have resigned themselves to the status quo, as revealed in the following:

$1_{\text {Ibid., pp. 67, 68. }}$ Ibid.

3 General Conference of SDA, Manual for Ministers, 1942, p. 30. 
Given the tradition in the Adventist church, its structure and organization and the actuality of the situation and conditions in the congregations, these ministers felt that little could be changed. And since his success in the ministry is determined by how well he performs under the present structures and demand--and nearly all the ministers showed a concern about their personal success and good evaluation by the conference-most congregations will not be stimulated in their continuous growth. 1

Some Practical Suggestions

Practical solutions have been suggested in the above report

as follows:

Revaluate the actual work of the minister in light of the counsel given by the scriptures and in the writings of Ellen White. The essence of their counsel is, a) that the minister is primarily a servant of God who is called to preach the Word of God. . . . Ministers are called to prepare the laity for their task of evangelism and to equip them for service and continuous church growth. . . That the church give careful study to ways of implementing the Biblical views of ministry. . . 2

In view of the above report and observations that have come out of it, certain changes or adjustments will be necessary to adapt to the present need. In addition to those already given the writer suggests two additional proposals: (1) Restudy the role of the laity within the SDA church in the light of the counsel of the scriptures and the writings of Ellen $\mathrm{G}$. White. The reformers and others sought to restore the full priesthood of the believers. However, because the clergy assumed authority for the church and the laity were inclined to expect the clergy to fulfill their roles as well, full restoration of a lay ministry did not take place. The new Adventist

${ }^{1}$ Oosterwa1, Patterns of SDA Church Growth, p. 68.

${ }^{2}$ Ibid., p. 69. 
movement was begun by laymen and laywomen. It was never intended that the lelergy should do the work of the laity. There was to be no conflict between clergy and laity. Each was to have his part in the life of the movement. The shared committment within the social system was to an unfinished task. Each person who espouses the message is to be a missionary worker. "Everyone who has received Christ is called to work for the salvation of his fellow-men."1 When these concepts are fully accepted and practiced considerable improvement will take place.

(2) The second suggestion, which is pertinent to this study, is that the pastor negotiate intentionally with the local church and not only with the local conference. Because of the enlarged variety of church situations one can no longer generalize regarding the work of the local pastor. Churches range in size from thirteen to three thousand and locales from rural to large urban centers. In an age of specialization and mobilization it seems feasible that study be given to particular needs in specific places.

Every pastor enters his work with a particular background, experience, and ability. If the church has expectations that run counter to his capacity to be socialized to those expectations conflict will result. Expectations will vary from church to church. No two pastors are alike. To avoid frustration and ambiguity and lowered performance, it seems crucial that an analysis be made of the local church social system's expectations along with the pastor's theological frame of reference and personal expectations.

${ }^{1}$ White, Acts of the Apostles, p. 110. 
Such an analysis can only be done by the pastor and his congregation. This is a private matter with only observer status being allowed to those outside the relationship.

\section{$\underline{\text { Summary }}$}

This chapter began by introducing the church as both universal, all believers, and local, a functioning institution. Both concepts stem from New Testament times. The local leader was identified as possibly the head of the house church center in which, it appears, the believers met for their fellowship and study. Furthermore it was shown that adherence to the church is seen as voluntary, the free choice of the redeemed person. As a voluntary religious social system the church tends to "socialize" the new believer or leader to its norms, values, and traditions.

The Seventh-day Adventist denomination, its development and organization, and the special influence of the writings of Ellen G. White were cited as an example of a voluntary religious social system. Finally, the local Seventh-day Adventist church and pastor, as observed today, were discussed. It appears that in spite of all the wealth of counsel available to the modern SDA pastor, he is unable to effectively stimulate the local church in its outreach and growth. Something more seems to be necessary. Certain practical suggestions to improve the situation for the local pastor have been set forth, one of which, negotiating an intentional ministry, is pertinent to this study.

How does the negotiating process take place? Who are the negotiating parties? What are the descriptive terms to be used and 
what do they mean? What is role theory? How can it be applied to the work of the pastor of a local Seventh-day Adventist church?. To the answering of these and other such questions the following chapter is dedicated. 
CHAPTER III

DEFINITIONS AND DISTINCTIONS, SIGNIFICANT OTHERS IN

THE SDA PASTOR'S WORK LIFE AND A VIEW TOWARDS

NEGOTIATING AN INTENTIONAL MINISTRY

Frequently throughout this study concerning the expectations of the local SDA pastor the terms "role," "role set," "role receiver," and "role expectations". are used. It is the purpose of this chapter to enlarge upon the definition of these terms. The chapter also illustrates the above-mentioned terms by applying them to the local SDA pastorate. Finally the chapter suggests a negotiated ministry as a new way to relate to the pastoral ministry in the SDA church.

The concern of this project is to make a distinction between the generalized approach to the study of the local pastor's work as opposed to a more specific approach. It is an attempt to particularize rather than to generalize; to discuss the pastorate from within a specific pastorate and with a specific pastor involved. While much has been written concerning the Protestant and Catholic minister's role a considerable amount of the material is too general to apply to the local SDA church situation. Because of this no literature study is presented here. However, some very useful material has been found and is referred to in the course of the discussion in this and other chapters. 


\section{Definitions and Distinctions}

The first term to define is the word "role" itself. According to the dictionary, "role" is: "A part or character taken by an actor," or "Any assumed character or function."1 In the light of the above definition, the term "role" may be appropriately applied to the pastor, his position, and functions. It may refer to a certain position or it may refer to certain functions within that position.

A second term or expression needing to be defined is "role expectations." This implies that there are expectations that go along with the assuming of a certain role. These expectations may accompany the assuming of the role or position. Role expectations exist within the religious social system, within the individuals that make up the system, and within the pastor of the religious social system.

This leads to a third expression that needs to be defined, the "role set." This refers to all significant persons or groups within the religious social system who influence the activities of individuals within the system. In the case of the local church pastor, his role set may include his wife and family, his local congregation and groups within the congregation, his local judiciary or conference, and his fellow-pastors in the community where he lives. A wide range of role expectations may accrue to the local pastor from so many and varied persons and groups. These various persons

IThe Reader's Digest Great Encyclopedic Dictionary (New York: The Reader's Digest Association, 1966), s.v. "Role." 
and groups may also be referred to as "role senders" in that they may send certain signals to the pastor as to their expectations of him.

While the pastor's role set makes certain demands upon him, it should be pointed out that it is within this context that the pastor is stabilized into his vocation. He and the health of the entire system depend upon whether the pastor is able to meet the expectations willingly and competent1y. In the previous chapter this was referred to as socialization, a conditioning or adjusting to the local customs, traditions, and expectations of the religious leader position.

A fourth and final term used frequently in this study is the term or expression "role receiver.". This refers to the person who is the focus of certain expectations from his role set. In this study it refers to the local pastor in a specific pastorate. As role receiver he also becomes the focal person, the one to whom expectations are directed.

The introduction of the terms described above is for the purpose of convenience in discussing the role of the pastor. They are expressions used frequently throughout this study.

Creating a Role and Role Expectations

As a religious leader the pastor symbolizes much more than himself. His

role and function have been bred into the deeper levels of the consciousness of those whom he serves. Therefore, he has symbolic as well as personal influence, and the symbolic power 
of his role gives him a strength far beyond that of his own personal appeal to people. 1

Some of the concepts of the role of the pastor which have placed themselves into the deeper levels of the subconscious mind might include images of the ideal pastor. These include: the memory of previous pastors, especially well-liked ones; popular lore prevalent in the culture as to the role of the pastor; class ideology of the community; images of successful pastors held by persons in official and unofficial positions of power; and the pastor's own expectations for institutional success. ${ }^{2}$ Along with the above there are other factors influencing the pastoral image in the minds of people. These include the titles attached to the office, such as pastor, preacher, reverend, elder, teacher, or evangelist. Each of these titles conjure up in the minds of the individual certain images based upon his experience and theological frame of reference.

Finally, the appearance of the pastor, his personality, and the spirit of enthusiasm, or lack of it, make their impressions. The image persons have of the pastor is influenced greatly by their observations of the pastor himself. This indicates that he not only "takes" a role and "plays" a role but that he "is" the role in a very real sense. It is all inclusive. As a Christian worker he is totally that which he claims to be, if he is genuine.

1 Wayne E. Oates, The Christian Pastor (Philadelphia: The Westminster Press, 1964), p. 43.

2 Milner, "Ministerial Role Expectations of Clergy," p. 21. 
A change in position may require a change in role. The person must experience a "fitting into" his new role. This takes time and a knowledge of what is expected of him in that role. He may not have changed in personality, but he is seen in a different light because he occupies a different role or position.

In summary, it appears that the expressions "role," "role expectations," "role set," and "role receiver" are helpful in discussing the life and work of the local Christian pastor. The pastor as the "role receiver" (focal person) obtains signals from his "role set" (his congregation) as to his duties ("role expectations"). Also, in taking the position the pastor changes in his relationship with others. It is as if he is clothed with his role. In this sense he is not just playing a role but he "is" the role. Finally, role expectations are created by impressions and symbols attached to the position. These impressions are registered deep within the consciousness of the pastor and of his role set.

It is now necessary to illustrate what has been stated in the above paragraphs by looking into a specific pastoral situation.

\section{A Look at the Seventh-day Adventist}

$$
\text { Pastor's Role Set }
$$

One author confirms what has already been briefly stated concerning the pastor's role set by saying, "All of those who relate to the pastor in the performance of his ministerial roles are part of his role set of his position as a minister." 1

${ }^{1}$ Donald P. Smith, Clergy in the Crossfire (Philadelphia: The Westminster Press, 1973), p. 25. 
In view of the above, a Seventh-day Adventist pastor may be functioning in many different roles all at the same time. He may be a husband, father, conference employee, conference committeeman, and district pastor as well as pastor of his local church. The significant others involved in these roles comprise his role set. Along with these influential others he is influenced by his own self-image of his role which is determined by his theological orientation and personal impressions concerning the work of the pastor:

Al1 of the above mentioned forces makes the task of determining the role of the pastor more complex than it first appears to be. One cannot simply approach the work of the pastor as a job description. Expectations vary from church to church and from pastor to pastor. The very existence of the local church is contingent upon the pastor's ability to fulfill his expectations peaceably, willingly, and competently. A war of expectations concerning the pastor's role among significant groups and individuals in the religious social system could mean its destruction. The importance of approaching the pastoral task with a specific place, congregation, and pastor in mind should be evident from the above observations.

Now, therefore, it is planned to narrow the discussion to the local Seventh-day Adventist church and to the other members of the SDA pastor's role set. 
The Pastor's Wife and Family

as Significant Others

Most ministers are married. The writer knows of only one or two unmarried Seventh-day Adventist pastors. What influence

does the pastor's wife have over him in his ministry?

It has been found by researchers that the pastor's wife and family have considerable influence in the pastor's role expectations. ${ }^{1}$ The pastor's wife and family appear to have particular influence in his choice of a career, as stated in the following:

The pastor's wife is the one person whose judgment and approval many ministers value most, and in studies of ministers who have left the pastorate there is some evidence that wife related reasons are high on the list. . . . It can be said that the husband role of the minister is, so far as his career decisions are considered, one of the most formative and influential of his role relationships. ${ }^{2}$

Ideally, the pastor and his wife have both responded to the call of God and both have a strong commitment to the pastoral ministry. However, as they enter into the actual work and experience some of their preconceived images of the ministry may be shattered. This could lead to second thoughts concerning their decision to enter the pastoral ministry. Mills, in studying those who left the pastorate and took up secular employment, found that such persons "experienced (the) largest number of unwelcome surprises upon first entering the ministry, which suggests incongruence between their initial image of the ministry and its realities." ${ }^{3}$ This incongruence may create more problems for the pastor's wife than for the pastor himself.

$$
1_{\text {Ibid., p. } 26 . \quad 2 \text { Ibid. }}
$$

3 Edgar W. Mills, "Career Change in the Protestant Ministry," Ministry Studies (May 1969):12. 
The tendency of the SDA pastor's wife today seems to be one of non-involvement in her husband's work. She assumes, it appears, the laity role rather than a ministerial role. She follows her secular professional counterparts and is employed outside the home. While very faithful to her husband and to her church, the SDA pastor's wife does not appear to consider her role to be one of working side by side with her husband. While this may not be generally the picture, it appears to be increasingly the case, as observed by the writer.

The Local Congregation as Part of the SDA Pastor's Role Set

A significant part of the pastor's role set is the local congregation. A major portion of his role expectations will come from this source. The congregation is also the center of the pastor's activity. It provides the pastor the major object for negotiation. Within the SDA organizational structure the local congregation does have autonomy in much of its local activity. However, with the conference serving as the central authority for the pastor, the human tendency is for the local church to lose its identity in its relationship with the pastor. In the SDA organizational structure the conference assigns and directs the pastor to a great degree. The pastor may have satisfying negotiations with his conference because of his employer-employee relationships. However, unless the pastor initiates the negotiative process with the local congregation no one is likely to do so. 
Whether the pastor initiates some type of negotiative ministry with his congregation or not, he himself will be socialized to some degree to the local congregation's values, norms, and traditions. If he resists this socializing process he will possibly encounter difficulty in his relationship with the local congregation.

In the SDA church organization it is comparatively easy for the pastor to move from one pastorate to another. This has its benefits both for the congregation as well as the pastor in that there is less direct confrontation between the pastor and his congregation concerning his employment. It appears that the frequent moves of pastors in the SDA church is due, in part, to their inability, or unwillingness, to be socialized to local church and cultural conditions. At least this has been shown to be true among pastors of other Christian bodies. ${ }^{1}$ The degree of success the pastor has in any pastorate appears to be often determined by his willingness to be socialized to the local.church, community, and culture.'

The Loca1 Community as Part of the Seventhday Adventist Pastor's Role Set

The local SDA church is located within a given community. The pastor is the chief representative of the church in that community. Jesus prayed that God should not "take them out of the world but that thou shouldst keep them from the evil" (Jn 17:5). Furthermore, counsel has been given to SDA ministers that they. should "come near to the ministers of other denominations.

Milner, Ministerial Role Expectations of Clergy, p. 14. 
Pray for and with these men for whom Christ is interceding. "1 The ministers are also encouraged to "give character and dignity to the work, . . [as] the third angel's message is to be set before them (ministers and the world's wise men) judiciously in its true dignity." 2 SDA ministers are encouraged to "speak in other churches." 3 All this indicates concern that the community receive a good impression of the work and message of the SDA church.

The unique beliefs of the SDA church on such issues as the observance of the Sabbath on Saturday tends to place it in a position of separateness from other Christian groups. Thus the SDA constituency, including the pastor, tends to be somewhat seclusive rather than participative in the community. In spite of the above counsel concerning the SDA ministers coming close to other ministers and wise men, a conservative guess is that not one in ten. SDA pastors is directly involved in community affairs. Even less directly involved are they with the Christian ministers in their community.

It is true that the community has only indirect influence upon the local SDA pastor's role expectations. The influence comes to bear upon the pastor through the local congregation. Therefore, the community in this study is treated as an extension of the local SDA congregation and not as a separate unit.

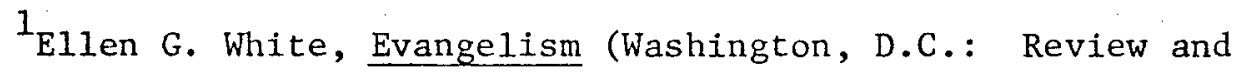
Herald Publishing Association, 1946), p. 562.

$$
2 \text { Ibid., pp. 562, } 563 . \quad 3 \text { Ibid. }
$$


The Local and State Conference as

Part of the Seventh-day Adventist

Pastor's Role Set

It has already been observed that the local conference has considerable power over the local SDA church and pastor. The pastor is called and assigned by the conference officers and executive committee. Thus, in the organizational structure, the pastor may consider himself first of all responsible to the conference organization. The human tendency could lead the pastor to do his work primarily with reference to the local conference rather than to the local church of which he is pastor. The local congregation might thus occupy a secondary position in the hierarchy of his obligations.

Since the local SDA congregation does not have much opportunity to involve itself, for instance, in the selection of its pastor and other significant matters, it may take one of three courses. (1) The congregation may become apathetic, noninvolved, or noncommitted to what is "handed down" to the local church by the conference; (2) it may be rebelliously vocal and troublesome to the conference leadership, or (3) it may willingly accept as from the Lord that which is suggested and cooperate to the best of its ability.

While the latter course is followed by most local SDA churches, there is also the tendency for many local congregations to become apathetic and noncommitted to the programs handed down to them from the conference. The result is stagnation and little growth either numerically or spiritually. ${ }^{1}$ Unless this tendency is 
reversed in some way, serious consequences may result that would interfere with the church's objective to carry the gospel to all the world.

The local SDA church pastor may perform his role in reference to the local conference officials and committee. Human tendency may also cause the conference officials and committee to expect the local pastor to do his work in reference to them. While there is obvious benefit to both the church and the pastor that the pastor is employed by the conference, this practice may cause some to fail to recognize that the local church is the basic unit of the conference. It is in the local church that the funds are given and from which personnel is recruited for service in the church. The implications for conflict or apathy within the church seem obvious. The pastor must determine how he will relate his own concepts of ministry with those of his employing organization and his congregation so that all are satisfied in their expectations.

In the report on church growth among Seventh-day Adventist churches in North America, it was found that SDA ministers generally place the conference above the local congregation in their hierarchy of important others in their role set. ${ }^{1}$ Possibly the SDA ministry has, to some degree, been responsible for lessening the influence of the local congregation by magnifying the importance of the local conference. By so doing the ministers have contributed to the apathy and non-involvement of the laity that they now are witnessing.

${ }^{1}$ Ibid., p. 66 . 
When the pastor reduces his involvement with his local congregation he may find a reaction of a similar nature to himself. The members may become less involved, more apathetic, and disinterested. The local pastor is a key person in the success or failure of any religious movement. It is no less so with the SDA church. A higher level of importance as to what happens in the local church will conform more fully to that which is stated in the following words :

The true honor and glory of the servant of Christ consists not in the number of sermons preached nor in the amount of writing accomplished, but in the work of faithfully ministering to the wants of the people. If he neglects this part of the work he has no right to the name of minister. 1

The local congregation takes its cues from the pastor. If he demonstrates his concern and interest in the local church, the church will react with concern and interest in the life of the conference which he represents. The pastor leads the way. This places heavy demands upon the pastor to devise some means by which he may deal with the conflicting demands made upon him. It is to this the study which follows is directed.

\section{Concerning Role Conflict and Ambiguity}

As stated earlier when a war of expectations develops within the church as to what is expected of the leader, the system is weakened and in grave danger of destroying itself. A diversity of expectations may exist in the church to a degree, but if the war of expectations explodes into an unresolved conflict, the existence of the church is endangered. 
Role conflict occurs when

Two or more expectations interfere with each other or contradict one another altogether. In a mild role conflict, the fulfilling of one expectation may merely make it difficult to fulfill another. In serious conflict, the compliance with one expectation may make it completely impossible to comply with the other. 1

Because the minister's role set is made up of a relatively large number of people with diverse backgrounds, convictions, positions, and special interests, the possibility of conflict for the local pastor is very real. The possibility is equally as real within the subgroups of the role set.

Al1 professions experience some conflict stress, however the minister's role problems seem to be more severe than those of the average professional. Reasons for this may include "the wide range of roles he must play in a position of high visibility, the intensity of some role pressures on him, and the almost complete identity between his self image and the roles he plays." 2

Role ambiguity, while not identical with role conflict, is closely related. Role ambiguity exists when the expectations of others or of oneself are unclear or confusing. If the pastor is. able to obtain up-to-date, adequate, and clearly defined signals from his church, conference, and significant others, he will keep ambiguity concerning his role down to a minimum.

Types of Conflict for the Pastor

Edgar W. Mills, in his position paper prepared to be read before the Research Conference on Ministry convened, made a significant

${ }^{1}$ Smith, Clergy in the Crossfire, pp. 26, 27. ${ }^{2}$ Ibid. 
statement concerning the possibilities of conflict for the pastor.

Because of its incisiveness it is quoted here in full:

The contemporary American clergyman is the key figure in the institution most closely identified with the value base of Western civilization. He moves constantly between the ancient and the modern, between principles and practices, and between the imperatives of love and justice. He, more than any other professional is bound to his calling by an ultimate commitment. At the same time, he is a professional whose clients are often his employers and whose theological ground of work today is being eroded even while his sphere of competency seems more and more peripheral to the technical expertise that moves the world. He is the one whose personal and occupational identities are necessarily linked to his religious identity so that all three stand or fall together. 1

Mills recognizes the difficulty in conceptualizing conflict

for explanatory purposes. He concludes that they fall into three

broad groups: (1) external expectations that create conflict, (2)

conflict between internalized norms and external pressures, and (3) internalized conflict. ${ }^{2}$

External role conflict occurs for the pastor when he is caught in the crossfire between the subgroups of his role set concerning the external obligations and expectations they have of him. It may be that his conference officials are in conflict with the local congregation, or it may involve certain age groups within the congregation itself. Hence, externalized role conflicts may be seen as "those in which the senders conflict with one another in their expectations and those in which the roles themselves conflict with one another." 3

${ }^{1}$ Edgar W. Mills, "Types of Role Conflict Among Clergymen," Ministry Studies 2 (December 1968):13.

2Ibid. $\quad{ }^{3}$ Smith, Clergy in the Crossfire, p. 32 . 
The second type of role conflict is labeled internal-external role conflict. This type occurs when "role requirements violate the needs, values or capacities of the focal person."I

Internal-external role conflict may occur in numerous situations in the pastoral ministry. An example within the SDA church is the frequent tension that develops between the desire of the pastor to do evangelistic work and the requirement of the conference that he administer the local church and perform numerous other duties as well. Or the pastor may be expected to do evangelism while he may prefer scholarly activities. His scholarly inclinations may create conflict with his external demands. The conflict occurs between the pastor's internal needs, values, or desires and the external demands. The third and final type of role conflict discussed here is the internalized role conflict of the local pastor. This type may possibly be the most personally devastating type of conflict for the pastor. It occurs when the conflict outside has come within and made him the center of a battlefield. It is when the "out-there" is "in-here."

Certain types of personalities tend to internalize conflict more than others. According to Bowers those who choose the ministry have saintly expectations of themselves and are inclined to be more sensitive to conflict than their tough-minded couterparts. ${ }^{2}$ The highly sensitive mind will tend to internalize conflict.

\section{${ }^{1}$ Ibid., p. 45.}

${ }^{2}$ Margaretta K. Bowers, M.D., Conflicts of the Clergy: A Psychodynamic Study with Case Histories (New York: Thomas Nelson and Sons, 1963), pp. 10-12. 
One example of internalized role conflict for the local SDA pastor is the norms expected in his profession. The servant model as pictured in the New Testament may severely cut across the successful minister model as pictured in his social context." Throughout his lifetime he may have seen and developed ideals of success which, in actuality, are contrary to the expectations of those he serves in the parish. He may internalize this conflict by carrying two conflicting norms within his psyche. Unless satisfactorily resolved and managed he will be inclined to suffer unnecessary anguish. As Smith observes, "To the extent that the servant role is internalized as a demand that the minister places upon himself and his family, he will find himself struggling with internal conflicts between legitimate self-interest and the unceasing demands of the parish." 1

The minister must seek to maintain a personal identity apart from his role as a minister. According to Ashbrook, "When an occupational role becomes all that a person is, rather than much that he is, the clergyman has lost touch with his own reality. Then the role hardens into a label shutting off vitality." 2

Finally the minister may accept as his own the conflict that others have regarding his role activities. Even though the parties involved may have long since resolved their differences, the pastor, may find the conflict persisting within himself. He thus becomes a self-sender of conflict. He may have considerable freedom to set

\footnotetext{
${ }^{1}$ Smith, Clergy in the Crossfire, p. 63. 
his own ministerial priorities that he accepts for himself. But since he has internalized the conflict of others he has his own war of expectations. He is "caught in crossfire of his own expectations." I

It is at this point that the minister may need outside help to work through his conflict. It is

When the minister's picture of the ideal self, the ideal clergyman, the perceived self and the perceived expectations of others is sufficiently incongruent, he needs help to work through just who he really is and what he has to contribute and where. 2

Any of the three types of role conflict, external, internal-external, and internalized, may contribute to the dilemma of the minister in his relationship to his parish ministry. Fortunately help is available to him. He need not despair, depart the ministry, or give up.

\section{Towards Resolving the Local Pastor's

$$
\text { Role Conflict by Means of a }
$$$$
\text { Negotiated Ministry }
$$

Every adult person has his own way of relating to internal and external conflict. This has developed through the various experiences of conflict during his lifetime. He may have never consciously analyzed his attitudes and approaches to conflict. He reacts without being aware of his own self-image. To change this style will require considerable effort and help. Conflict management is designed to be of help in developing a proactive style rather than only a reactive style when faced with role conflict.

$$
{ }^{1} \text { Ibid., p. } 65 .
$$


Role conflict may be found in most professions. Some people actually enjoy the diversity involved in the multi-role occupations. Their natures tend to adapt well to diversity. They would be bored in work involving less variety. Because the ministry is particularly a multi-role profession, it is true, as Campbell states, that

If one does not have some desire for diversity of functional roles, then one probably should not attempt to exercise leadership in a voluntary church institution. Multiple expectations put some limits on the intentionality of all ministers, but they also put limits on the kinds of persons who should seek to be clergy. 1

As stated earlier diversity may be a source of conflict but not the only one. But it would certainly be more of a conflict to certain types of personalities. It is of interest that certain studies show that the ministry tends to attract the more passive personality. ${ }^{2}$ Such persons may tend to avoid conflict and suppress their feelings. They also tend to conform more to organizational criteria for success rather than having their own personal criteria. The passive person would tend to be more reactive than proactive. That is to say, he tends to give priority more to external demands than to internal needs. Speed B. Leas states that this is a rather "general stance among clergy: they are, 'seeking to remove the distress caused by conflict rather than looking for help to accomplish positive goals." 3 It should be added, however, that no one is totally reactive or proactive in his ministerial stance. It merely

${ }^{1}$ John R. Biersdorf, ed., Creating an Intentional Ministry (Nashville, Tenn.: Abingdon Press, 1976), p. 47.

${ }^{2}$ Smith, Clergy in the Crossfire, p. 109. 3iersdorf, ed., Creating an Intentional Ministry, p. 195. 
points out that the tendency exists within the clergy to be passive and reactive rather than proactive or goal-oriented or intentional in their approach to ministry.

It appears that those SDA ministers surveyed in the churchgrowth report revealed passive and reactive tendencies as well. ${ }^{1}$ Their response to the conflict between what was expected of them and what they themselves desired reflected passive acceptance. The SDA ministers surveyed related to their conflict by stating that they would be unable to change their role so long as the present denominational structure was maintained and the demands which that structure imposed upon them was sustained. While it is possible the denominational structure does create such demands, yet SDA ministers are not helpless. They have considerable freedom of action. Helpful resources are at their demand and new approaches to the pastoral ministry are waiting to be developed.

The Basis of Negotiation

It is at the point of negotiation where successful change may be implemented. Since the church is a voluntary social system and certain expectations are placed upon every member as well as the leader, no one may change his role arbitrarily. He must first negotiate his role change with his role set.

An intentional negotiation. What is meant by an intentional negotiation as it relates to the local pastorate? It "refers to the quality of transactions between the minister and the persons and

${ }^{1}$ oosterwal, Patterns of Church Growth, p. 68. 
groups with whom he or she carries out his or her professional work."1 Negotiating an intentional ministry is a verbal model or organizing principle which is useful in describing the model for ministry suggested by this project. It envisions a new way to relate to old problems--problems of identity for the pastor himself and the way he relates to the expectations of others in his local church. It includes being proactive, goal oriented, and planned in one's approach to his ministry in the local pastorate. Being intentional includes the pastor's own personal goals for himself in competence, specializations, family, and continuing education. It means directing, as far as possible, the affairs of one's life rather than being driven by external pressures.

Because the church is voluntary. Since the church, as has been pointed out earlier, is voluntary the pastor is constantly in the process of building a constituency. The importance of negotiation is enhanced by the vulnerability of the pastor in the voluntary religious system. He has none of the coercive devices available to him that are available to business and industry executives. To hold his constituents there are no coercive, material, or political pressures legitmate for the pastor. There are many ways the church may resist the pastor if it is unhappy with him. Its "membership can disappear or offer various forms of resistance (no show, no pay) when the church is not moving in a direction they desire." 2

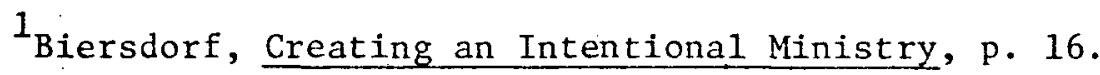
${ }^{2}$ Ibid., p. 139.
} 
Because the local church is heterogenous. A further basis for negotiation may be found in the wide diversity of attitudes and ideas within the pastor's role set. Even though each member is being directed by the Holy Spirit, considerable divergence may exist among the membership as to what is good for the whole commun1ty. This heterogeneity may provide a challenge to the pastor to negotiate the wide diversity of opinion and develop a consensus. To include the local church and conference. The need for the SDA pastor to negotiate an intentional ministry is particularly urgent due to the type of church organizational structure. Since considerable authority is perceived to be centralized in the local conference and upper levels of the SDA organization, the local church may tend to deny its own local autonomy. It may tend to feel that it is being other directed than inner directed.

The pastor also may reflect a "conference directedness" in his approach to his work. Because of this he may fail to recognize the importance of negotiating his ministry with the local church as well as with the conference. Thus the local church may sense no local identity.

However, like its pastor, the local church is not helpless. It may have more freedom than it may realize at first. While the denominational structure may tend to be conference centered, in actuality, there is considerable autonomy in the local SDA church. If the local SDA pastor recognizes this he will pay equal attention to his local congregation as he pays to his conference and negotiate accordingly . 
Negotiation as an alternative to moving. Finally, negotiation

may provide a viable alternative to the relocation syndrome which affects many ministers. The frequency of pastoral moves has often been a source of frustration on the part of many laymen as well as some pastors. While at times it may be essential for some pastors to be given a new start, there are instances in which the pastoral image is weakened and his power of coping with himself is left unresolved. The point is that some means must be devised on the part of the pastor and the local congregation whereby the pastor may renegotiate his ministry in that place. A strong case is presented in the following words:

Negotiation emphasizes the importance, even the necessity of continually working out a fresh sense of self-worth and new role expectations with our congregation and community right where we are--not simply on those infrequent occasions when we are in conversation with the pulpit nominating committee. We are seduced too easily and too quickly by a dossier-resume system that lists the congregations or agencies we have served rather than those moments when we successfully negotiated a deeper sense of personal identity or a new role expectation with our congregation. 1

While the final decision concerning the relocation of a pastor may need to be left to those involved, the concern is that both the pastor and the congregation have opportunity to negotiate anew their roles and create an intentional ministry as a viable option as opposed to moving.

The above-mentioned reasons for the local pastor negotiating his role in the local church provide a basis for entering into the process. Certain steps must be taken before the actual negotiation

$$
{ }^{1} \text { Ibid, , p. } 21 \text {. }
$$


between the pastor and his role set may commence. A few are presented in the next section.

The Negotiating Process for

the Local Pastor

At the outset it should be stated that the local SDA pastor stands as a connecting link between the local church and the larger church body. He, therefore, must negotiate in two directions, with the local church and with his employing organization. He "owns" the total denominational program in that he is the connecting link.

The local pastor seems to be cast in the "connecting-link" role by the SDA Manual for Ministers: "Upon him [the pastor] rest[s] the responsibility of overseeing and fostering all branches of the work. . . [He] should familiarize himself with the methods of organizing and carrying on al.1 these activities. "1 While this may appear to be beyond the ability of one individual to perform, yet by applying the suggestions which follow the pastor may achieve a high degree of success.

To be intentional means to intend, to determine, to plan to do something. Negotiation, on the other hand, is to determine what way the intentions may best become a reality. Intentional negotiation involves a shared experience between the parties involved. What are the prerequisites to a successful negotiation between the SDA pastor and his church and his conference?

Openness of the pastor about himself. The pastor sets the tone of the negotiating process. A first essential is his willingness

${ }^{1}$ Genera1 Conference of SDA, Manual for Ministers (Washington, D.C.: 1942), p. 30. 
to engage in open sharing of himself. It implies a willingness on the part of the pastor to admit his humanness. For many ministers this may be very difficult. Pastors often find it difficult to admit to.human and spiritual weaknesses. As a result pastors often make poor negotiators. They find it difficult to share with others their inner feelings, thoughts, and visions for themselves.

To negotiate effectively, the pastor must ultimately develop an openness about himself and his life. To achieve this he may need outside help from those who are able to assist him. Numerous training resources are available for ministers who wish to develop this open style of leadership.

The pastor makes a self-assessment. Associated with developing an open style of leadership is the need for self-knowledge in the negotiating process. As a professional person the pastor must negotiate from a realistic picture of himself and his abilities. It is much more likely that congregations and conferences will respond positively to the pastor who has clearly defined ideas about his skills, competencies, preferences, and goals for himself. If he is unclear about these things, he may receive a negative reaction.

If the pastor tries to do all things because he is unclear as to what he does well, he will likely find his congregation and conference reacting negatively to the negotiating process. Again the pastor may need help in ascertaining his skills, personal strengths and weaknesses, and even his occupational preferences. 
To help the pastor in the above-mentioned matters personality inventories, vocational preference surveys, and similar tests geared mainly for the minister may be taken at a number of centers. Today theological seminaries are often equipped to provide such a service. In recent years a number of Career Development Centers for Clergy have been established at several locations in the United States. Along with the tests and surveys, professional counseling is available at these centers.

The point is that the pastor must set the tone for the negotiating process by reflecting an open style of leadership. To do this he must make some effort to determine just who he is so that from this position of self-knowledge he may encourage the congregation to follow his example in the process.

A self-study of the local church. A third essential in the negotiating process for the local pastor is that the church give some study to itself. This may be called self-assessment or self-knowledge as well. Not only must the pastor obtain a knowledge of himself but so also must the local congregation find some means of knowing its strengths and weaknesses, goals, competences, and skills. The tendency on the part of many pastors may be to confront the church with the purpose of negotiating plans for the future without first engaging in an evaluative experience.

According to Lewis, self-assessment is "a process by which valid data is gathered concerning a person's perceptions and feelings about what is happening and what they wish would happen." 1

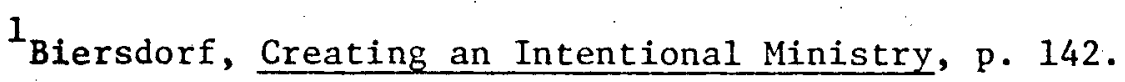


Before profitable negotiation can take place within a local church congregation and conference, the pastor should encourage the church to engage in self-assessment. This should precede the setting of goals. Otherwise, goals are set without the benefit of present and past information.

Develop a data-gathering instrument for the local church. To negotiate successfully it is necessary for the pastor and his congregatiọn and conference to obtain information about each other's attitude toward the various ministries of the church. The purpose is to reduce the amount of "mind reading" each part of the role set is doing about itself and the ministry.

The data may be obtained through a simple questionnaire or survey which includes localized church issues as well as those that are more general in application. ${ }^{1}$ It is essential that it be prepared for the local congregation and contain issues which involve the local congregation and pastor. It might be helpful for several of the congregation's leaders to serve as consultants in developing the instrument and to legitimize its use by the congregation.

Negotiate goals compatible to both pastor and church. According to Gunn, "Goal setting and evaluation are among the important negotiating skills of the intentional minister. " ${ }^{2}$ Unless the local pastors are goal-directed persons they may "experience free floating anxiety about themselves and their ministry and plague

\footnotetext{
${ }^{1}$ See exhibit A for survey instrument used in this study. ${ }^{2}$ Biersdorf, Creating an Intentional Ministry, p. 124.
} 
themselves with unexamined guilt feelings about their competence and relevance as leaders of the congregation." 1

While every pastor has intentions or goals for himself and his congregation, it is true that "the minister's goal-setting and evaluation cannot be separated from the congregation's goals and its evaluation of its life and work in relation to those goals." 2 Both the pastor and the congregation have vested interests in their goals. Ideally the pastor's devotion and purpose should be in direct proportion to the congregation's clarity about the meaning and purpose of its corporate life. The reciprocal benefit both to the pastor and the congregation may be seen in the following statement: "The congregation that has a visible and communicable sense of what it is about will 'produce' ministerial leadership characterized by purposefulness and a sense of professional worth." ${ }^{3}$ Thus the congregation may, in a sense, "make" the minister, because it greatly influences him in his ministerial image.

Furthermore, when it comes time to evaluate the pastor it will be "more than just an evaluation of the minister's performance; but the evaluation of the minister when done within the context of the congregation's evaluation takes on the dimensions of teamwork and mutual trust and accountability." 4 The congregation thus shares both in the successes as well as the failures of the total ministry of the pastor and church. In such an evaluative experience the church may become aware of their own successes and failures.
${ }^{1}$ Ibid., p. 128.
${ }^{2}$ Ibid., p. 132 .
${ }^{3}$ Ibid., p. 133 .
${ }^{4}$ Ibid. 
Emerging from the experience may be new goals that may be more realistic and compatible with the ability of the church and pastor. Concerning negotiation with the local conference. The local SDA conference consists of a group of local churches which have a central headquarters and leadership. It has been mentioned from time to time that the local SDA conference wields considerable authority over both the local pastor and church. Therefore, the conference leadership will, of necessity, need to have at least observer status in the pastor's negotiation with his local church.

It is assumed that the pastor, because of his employeremployee relationship to the conference, will maintain an ongoing negotiating relationship with his conference officials. Matters of personal finance, housing, position, continuing education, and so forth are matters that would be involved in the pastor's negotiating relationships with his local conference. It is not within the scope of this study to concentrate on this aspect of the negotiating process. However, the conference official and minister group is important as a significant "other" in the pastor's roleset. Their responses to questions in the survey concerning the role expectations of the local pastorare important to this study. Negotiating an intentional ministry is admittedly a rational approach. However, it is also a sensing and feeling approach to ministry in the local SDA church. It seeks to get in touch with how the pastor and his role-set feel and to stay in touch with those feelings rather than to ignore them. It is a deliberate attempt to uncover hidden mind-reading attitudes which may have 
caused much unnecessary internal or external role conflict. Thus through collaboration and negotiation a consensus may be obtained and a deeper commitment of both pastor and congregation to the goals which result from the process. ${ }^{1}$

\section{Summary}

In this chapter an attempt was made to define the terms "role," "role expectations," "role set," and "role receiver." These terms were then applied to the local SDA church, conference, and pastor to illustrate their use and to provide a basis for the survey that follows.

Role conflict and role ambiguity were identified and discussed under the three types of conflict--external, internalexternal, and internalized--as experienced by the pastor of a local church. This led to seeking for a solution for the local pastor. The model for negotiating an intentional ministry was then suggested.

Basic to the negotiating model for the ministry are certain factors. Among those mentioned were: negotiation must be intentional, the nature of the church is voluntary, each member must "own" the system, both church and conference must be included, and negotiation becomes an alternate to pastoral moves. Basic to the negotiating process are certain guidelines for the pastor and his role set. The guidelines suggested were as follows: the pastor plement an intentional negotiation with the local congregation. 
must be open about himse1f; the pastor must know himself, his dominant skills, and preferences; the church must engage in a study of itself, goals, and resources; a data-gathering instrument must be developed by and for the local church setting; and goals must be negotiated that are compatible to the pastor, the local church, and the conference.

It is toward this matter of negotiation that this study has been directed. The pastor is to negotiate with his entire role set, not only at the beginning of his service in the local church but at every step of the way. This will tend to resolve conflict, reduce ambiguity, and enhance the total ministry of the church.

To negotiate intelligently it is necessary to obtain information from the various persons, groups, and subgroups of the entire role set. This may be done through some means such as a questionnaire or survey form. The information obtained via the questionnaire may provide some indication of trends and attitudes that will advise the pastor regarding his responisibilities toward his role set. It may also help point out areas of possible conflict, ambiguity, and frustration for the pastor. Finally it will provide the basis of negotiation for the pastor, his congregation, and the conference. The study now turns to a description of one pastor's attempt to administer such a questionnaire to his role set and then to analyze the results. 
CHAPTER. IV

\section{A DESCRIPTION OF THE FOCAL PASTOR'S ROLE SET, HIS POSITION, AND SELF-ASSESSMENT}

\section{Introduction}

An attempt is made in this chapter to present brief verbal pictures of some of the significant groups and persons that influence a particular pastor in a specific place. The church and congregation, the city, the conference, the position, and the pastor himself as the recipient of expectations from these groups will be described. It is an attempt to identify a specific pastor's role and the pastor himself. A time study based on actual records follows the discussion of the pastor's position.

\section{A Description of the Grand Rapids Central Seventh-day Adventist Pastor's Role Set}

The three major groups discussed in this section will be the church, the city, and the conference. The pastor's position and time study follows in a subsequent section.

\section{The Church}

The Grand Rapids Central Seventh-day Adventist church is located at 100 Sheldon Blvd,, S.E., Grand Rapids, Michigan. The location of the church is near the downtown area of the city. Other major denominational churches located in the same general 
area include Catholic, Christian Reformed, Presbyterian, and Syrian Orthodox. A specialized hospital facility occupies space immediately across the street and a major hospital facility is located three city blocks away.

The church's physical facilities include two areas, the new and the old. The old facility was purchased from another congregation in 1939 and renovated. It houses the main worship sanctuary, fellowship hall with an adjoining kitchen plus general storage and rest rooms. The main sanctuary is nearly square lending itself to closeness between the speaker and his audience. The new addition, recently built and dedicated, houses Sabbath School facilities for children and youth, a small prayer chapel, a choir or conference room, and a pastor's study.

The congregation was first organized in 1887 with thirtyfive members. It has grown steadily in membership until today there are over five hundred, the fifth largest congregation in the Michigan Conference of Seventh-day Adventists.

other congregations have been spawned or strengthened during the years of the congregation's existence. These include the Wyoming church, the Sparta congregation, and a Spanish-speaking congregation recently organized.

From the time of its organization to the present, thirtyeight pastors have served the church, and a large number of young men have served as assistant pastors. The average tenure for the senior pastor has been approximately 2.34 years. The writer served the congregation from December 29, 1973, until October 1, 1976. 
The City

The city of Grand Rapids ${ }^{1}$ is located in the western part of Michigan's lower peninsula about 139 miles northwest of Detroit on interstate highway 96. It is about twenty-eight miles from the shores of Lake lichigan. The city straddles the Grand River from which the name Grand Rapids was obtained.

The city is built upon what was once an Ottawa Indian village. In 1825 a Baptist Mission was established and the following year Louis Campau selected the site for his $\log$ cabin and an Indian trading post. Grand Rapids was incorporated as a village in 1838 and as a city in 1850 .

The first furniture factory was built in 1859, and the city became known as the furniture capital of the world. Today the city boasts of a metropolitan population of $200,000 .^{2}$ It is characterized by a much greater industrial diversity today with more than two thousand different types of articles produced in the city.

A large segment of the population is made up of Dutch descendants. This is reflected in the dominant religious groups in the city. The Reformed and the Christian Reformed traditions reflect themselves in a strong Protestant trend in the city. Practically all religions of America may be found there, however. It is a city of churches with approximately three hundred different church buildings. 3

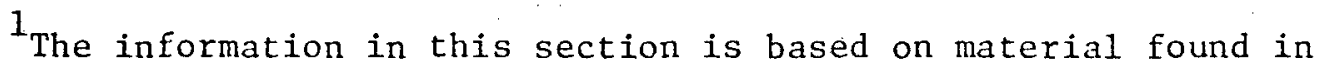
the American Peoples Encyclopedia, 1970, ed. s.v. "Grand Rapids."

${ }^{2}$ Greater Grand Rapids Chamber of Commerce, Greater Grand Rapids (Grand Rapids, Michigan, 1967). 
Three major religious book producers are headquartered in

Grand Rapids. This could also make it the religious book-producing capital of the world.

It is the seat of Calvin College, Calvin Theological Seminary, Aquinas College, Baptist College and Seminary, Davenport College, Grand Valley State College, and the Grand Rapids Junior Co1lege.

A number of religious radio stations provide outlets for the Protestant fundamental and evangelical theological viewpoint. A definitely religious atmosphere pervades the city and affects the cultural, social, and political system. Such an environment affects also the Iocal Seventh-day Adventist population and influences them in their expectations of their pastor.

\section{The Conference}

The Grand Rapids Central Seventh-day Adventist church is a part of the Michigan Conference of Seventh-day Adventists with headquarters at $320 \mathrm{~W}$. St. Joseph, Lansing, Michigan. ${ }^{1}$ Organized in 1861, the conference has the distinction of being the first official organization in the Seventh-day Adventist denomination. It was at that time that the denominational name Seventh-day Adventist was selected.

Upon organization of the denomination on May 21 , 1863, the city of Battle Creek, approximately fifty miles southeast of Grand

${ }^{1}$ Most of the material in this section is taken from The Seventh-day Adventist Encyclopedia (Washingtin, D.C.: Review and Herald Publishing Association, 1966), s.v. "Michigan Conference." 
Rapids, became the headquarters for not only the Michigan conference but also for the entire denomination. Battle Creek remained the international headquarters for the church until 1903, at which time the General Conference offices were moved to. Washington, D.C. Following its initial organization the Michigan Conference was divided into smaller geographical sections which were organized into independent conferences. However, in 1931 these were discontinued and the entire state of Michigan reunited as one conference. The conference offices were, at that time, moved from Battle Creek to Lansing, Michigan.

Today the Michigan Conference geographically encompasses the entire state of Michigan. At the end of 1975 there were 157 churches and 20,378 members in the conference. ${ }^{1}$ Also at the end of 1975 there were 113 ministers and four Bible instructors serving in the various levels of the organization. Educational institutions include fifty elementary'schools and five secondary academies. There are 3,645 students enrolled in these elementary schools and academies. One of the two major graduate universities operated by the denomination, Andrews University, is located within the conference at Berrien Springs, Michigan. The Seventh-day Adventist Theological Seminary is also located at Berrien Springs. One major medical institution operated by Seventh-day Adventists is located at Battle Creek.

\footnotetext{
${ }^{1}$ Directory of the Michigan Conference of Seventh-day Adventists (Lansing, Nichigan), p. 4.
} 
The conference is presided over by a president, a secretary, and a treasurer who serve as officers and are responsible to a conference executive committee composed of twelve ministers and laymen. All are elected at the triennial conference session by delegates from the churches in conference session. ${ }^{1}$ The president, secretary, and treasurer devote full time to administrative matters, whereas the committee members maintain their own employment. The committee meets once each month and is mandated to care for any business matters relating to the Michigan Conference during the interim between conference sessions. ${ }^{2}$ Once each year a short conference session is held to hear reports of progress and to give the officers opportunity to share any pertinent information with the delegates from the constituency.

The current conference committee for the Michigan Conference is composed of six ministers and six laymen, excluding the three officers. Of the six ministers serving on the conference executive committee, five are pastors and district superintendents and one is the conference ministerial secretary. Of the laymen, five are men and one is a woman. Two of the laymen are successful businessmen, one is a medical doctor, one a dentist, one is president of Andrews University, and the lady is the wife of a medical doctor.

Inasmuch as the conference officers and committee function as the employing body for pastors to serve in local churches, the

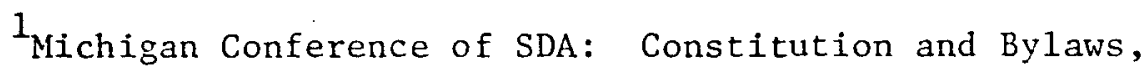
Article 4, Section 1, "Executive Committee."

${ }^{2}$ Ibid. , Section 2 . 
attitudes and theological frame of reference in which they operate is significant to this study. Most of the committeemen are seasoned ministers or laymen, some of whom have served a number of years on the executive committee. All except the two businessmen have a college baccalaureate degree or more in educational achievement. A11 have obtained most of their upper level education within the denominational educational system.

\section{The Pastor's Position in the Conference and in the Church}

As pastor of the fifth largest church in the Michigan Conference the senior pastor of the church is permitted an assistant pastor to help him with his work. Denominational tradition varies from conference to conference but generally it allows an assistant pastor to a church when it reaches a membership of from 400 to $500 .^{1}$ The assistant pastor usually is beginning his ministry and serves one to two years, It being his first ministerial appointment he depends heavily upon the senior pastor for guidance and leadership. Since his tenure is short and his experience limited the amount of assistance given may be somewhat limited particularly in certain areas of ministry.

An organizational feature unique to the Michigan Conference is the district superintendency. Because of the size of the Conference both numerically as well as geographically, the state of Michigan has been divided into a number of districts, each under

${ }^{1}$ As per phone conversation with Charles Keymer, president of the Michigan Conference of SDA, 22 April, 1977. 
the leadership of a District Superintendent. These districts contain a group of churches selected somewhat according to the size of the membership involved as well as the geographical locations. It is not an attempt by either the conference or the district superintendents to restrict individual church pastors from directly approaching any of the conference officers; however, the conference officers do depend on the district superintendent to carry information to and from the office headquarters.

The Grand Rapids pastor has traditionally functioned as a district superintendent. Grand Rapids is number four out of the twelve total districts in the Michigan Conference. It includes the Grand Rapids Spanish, Grand Haven, Wright, Muskegon, Fremont, Ludington, Shelby, Sparta, Wyoming, Bauer, and Holland churches. A total of seven pastors serve these ten congregations. The following ten responsibilities for district superintendents were drawn up by the Michigan Conference Officers and presented to the district superintendents at a special meeting held April 27, $1976 .{ }^{1}$

1. To serve as moderator and counselor within the district and give assistance to the handling of any special problem.

2. To arrange for district workers' meetings with the pastors from time to time, possibly once a quarter.

3. To assist the pastors in planning evangelistic crusades and building programs.

4. Occasionally make himself available to take Sabbath worship appointments in the churches in the district.

5. Check with the pastors concerning vacation schedules and, with counsel with the conference secretary, assist in providing guest speakers during vacations and during the time when pastors are being transferred.

${ }^{1}$ Michigan Conference of SDA, "Responsibilities of District Superintendents," Lansing, Michigan, 1976. (Mimeographed) 
6. Work out schedules within the district for the pastors who wish to exchange pulpits occasionally.

7. Check with the pastors occasionally on church or school needs and work out plans with them to meet those needs. Help prepare any special requests that should be presented to the Conference Administration.

8. Communicate regularly with the Conference Administration on the progress and needs of the work within the district and request conference assistance whenever necessary.

9. Attend church board meetings and other special meetings in the churches. when needed and invited by the pastors in the district.

10. Collaborate with the Conference Officers as to the types of personnel needed for certain positions in the district.

After thoroughly discussing the responsibilities listed above

the combined group of district superintendents and conference officers agreed that the list represents the major duties of a district superintendent in the Michigan Conference. It was suggested that each district superintendent comply with these recommendations as he sees best. In addition to the above district duties, the Grand Rapids district superintendent and pastor often has the responsibility of serving as hospital chaplain. This ministry includes the members of not only his own church but also in behalf of those Seventh-day Adventists from other churches in Western Michigan outside the immediate area of Grand Rapids. This is because some major medical centers are located in the city, due to its size and strategic location. Understandingly, frequent calls come from members and pastors of other churches requesting the pastor in residence to visit loved ones and nembers who have been referred to and hospitalized in one of the five major hospitals within the city.

Besides the responsibilities as district superintendent and hospital chaplain, the Grand Rapids pastor is, of course, expected 
to fulfill the other duties relating to his work in the local church. Al1 of this means that he must be able to manage his time well. While much time is required, it is not the amount of time but the burden of responsibility that is crucial to the pastor. Certain things are expected of him. A feeling of inadequacy, conflict, and frustration may result.

The pastoral ministry is admissably not unique in terms of heavy work loads. However, while many people in other professions may work even longer hours, most ministers work long hours at very demanding tasks. An Episcopal study reveals that the average work week of the parish priest is 66.7 hours. ${ }^{1}$ There is little reason to believe it would be different among Seventh-day Adventist clergymen. It is noteworthy, however, that the amount of time required of the pastor increases in proportion to the size of his congregation and the size of the city in which it is located. There is more of everything to do. There are more funerals, more weddings, more marital problems, and more spiritual and personal problems. A study conducted a number of years ago is pertinent to this matter. ${ }^{2}$ It found at that time that the rural pastor worked on an average of nine hours and seventeen minutes per day, whereas the city pastor worked ten hours and thirty-two minutes per day. In other words, the city pastor, who generally has more of everything to do, averages one hour and fifteen minutes more per day at his work than his ruralpastor colleague.

${ }^{1}$ Smith, Clergy in the Cross Fire, p. 29.

2 Samuel W. Blizzard, "The Minister's Dilemma," The Christian Century, April 25, 1956, p. 509. 
How much time does the local pastor of the church in this study spend in his ministerial work per week? To give a clear answer to this question a time study based on actual records is presented here.

\section{A Time Study of the Position Involved}

In anticipation of this study it was the writer's privilege to record the number of hours spent during an average week during the month of January, 1976. For a total of twenty-five days during the month of January, the time involved in the various ministerial activities and conference and district-superintendent duties was recorded. The total number of hours spent each day and the specific activities engaged in during the day may be observed in table 1 . Only the time spent in church, conference, or district matters was recorded as work time. Activities such as eating, rest periods, personal business, and social time with the family were not counted as work time. Included were all church meetings, driving time, personal prayer and devotion time, and all other types of ministerial activity related to the church. A fairly accurate moment-by-moment accounting was kept. The hours were rounded to fifteen-minute segments to avoid overly meticulous record keeping and totalling.

A simple calculation reveals that the writer averaged 10.58 hours each day for the twenty-five-day period from January 8 to February 1, 1976, ir his duties as pastor of the Grand Rapids Central church. It shouid be observed that the pastor was away from the local church attending several meetings called by the conference. 
TABLE 1.--A twenty-five-day record of actual work time of the Grand Rapids Central SDA Church pastor, January 8 to February 1, 1976

\begin{tabular}{|c|c|c|c|c|}
\hline \multicolumn{2}{|c|}{ Date } & \multirow{4}{*}{$\begin{array}{l}\text { Week Day } \\
\text { Thurs. } \\
\text { Fri. } \\
\text { Sabbath }\end{array}$} & \multirow{2}{*}{$\frac{\text { Work Hours }}{11}$} & At church office--Saneral dutiec \\
\hline Jan. & 8 & & & At church office--General duties \\
\hline & 9 & & 9 & Sab. sermon--Sab. preparation \\
\hline & 10 & & 12.7 & $\begin{array}{l}\text { Preached; S.S. Council; L.A. } \\
\text { Council; Social }\end{array}$ \\
\hline & 11. & Sun. & 9 & $\begin{array}{l}\text { Catch up day; Planning; Hosp. } \\
\text { visits }\end{array}$ \\
\hline & 12 & Mon. & 12.5 & $\begin{array}{l}\text { Conf. Committee; Begin Workers } \\
\text { Meeting }\end{array}$ \\
\hline & 13 & Tues. & 11 & Workers Meeting \\
\hline & 14 & Wed. & 12 & $\begin{array}{l}\text { Worker's Meet. \& drove home for } \\
\text { funeral }\end{array}$ \\
\hline & 15 & Thurs. & 10 & $\begin{array}{l}\text { Funeral preparation \& funeral; } \\
\text { visits }\end{array}$ \\
\hline & 16 & Fri. & 6.5 & Sab. preparation; General duties \\
\hline & 17 & Sabbath & 8.5 & Guest speaker; Afternoon meeting \\
\hline & 18 & Sun. & 4.5 & Hospital visits; with family \\
\hline & 19 & Mon. & 12.5 & General ministerial duties \\
\hline & 20 & Tues. & 11.5 & General duties and visits \\
\hline & 21 & Wed, & 10.5 & Team visitation; Prayer meeting \\
\hline & 22 & Thurs. & 14 & Conf. Com.; Evening Bible studies \\
\hline & 23 & Fri. & 13 & Sab. Ser. prep.; special eve. mt. \\
\hline & 24 & Sabbath & 12.7 & Preached; Ingathering vic. soc. eve \\
\hline & 25 & Sun. & 6 & A Com. meet.; Visits at hospital \\
\hline & 26 & Mon. & 11 & Gen. duties and visits \\
\hline & 27 & Tues. & 12.5 & Gen. duties; academy annual bd meet \\
\hline & 28 & Wed. & 13 & Two academy board meetings \\
\hline & 29. & Thurs. & 11 & Academy bd. meet.; Gen. duties \\
\hline & 30 & Fri. & 11.5 & Sab. prep.; General duties \\
\hline & 31 & Sabbath & 10 & Preached; L.A. Coun. \& E1d. meet. \\
\hline Feb. & 1 & Sun. & 8.5 & Pastor's council \& social for dist. \\
\hline & 20 & & & \\
\hline
\end{tabular}

There were two conference committee meetings, one three-day worker's meeting, and a two-and-one-half-day Academy Board meeting. These special meetings might tend to increase the amount of time required from the pastor. The time involved in making arrangements to attend meetings away from the local church is often overlooked. Also the time needed to catch up when the pastor returns adds hours to his 
work 1oad, However, it is not likely the figure of 10.58 hours per day would be reduced as an average even during normal times in the life of the pastor. A spot check during the month of February revealed that the writer followed much the same pattern in work time.

It may be observed that certain days were heavier than others, and Sunday was treated partially as a day off. However, even Sunday involved certain committee meetings, personal counseling, and hospital visitation. Table 2 gives a breakdown of the number of hours the writer spent working each day of the week as averaged over the twenty-five-day period:

TABLE 2,--Average hours of work per day of the Grand Rapids Central SDA Church

pastor

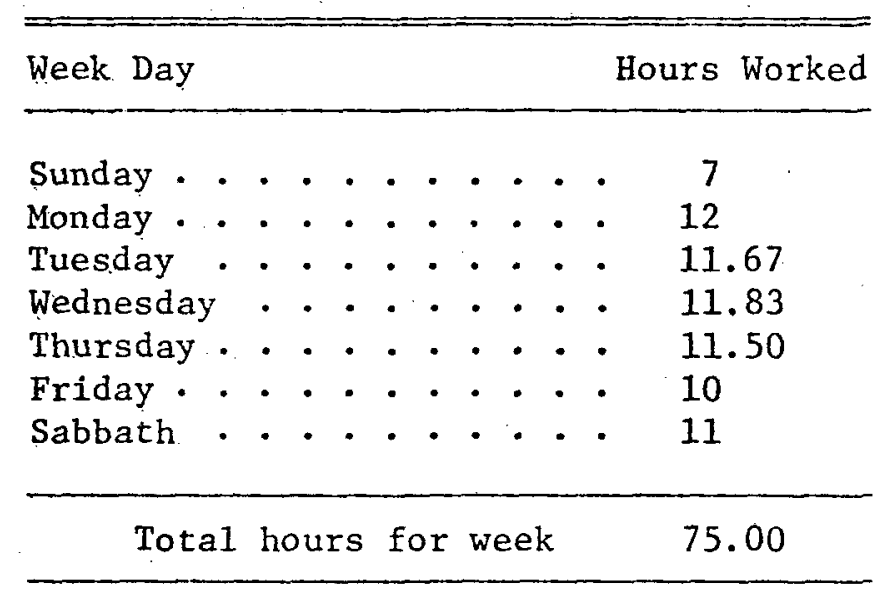

What does the Grand Rapids Central pastor do with all his time? What activities occupy most of his time? In this study the intention is to be as specific as possible. To accomplish this the writer kept a moment-by-moment account of a typical day in the parish. The specific activity and the number of minutes involved were recorded Immediately upon completion of each task throughout the day. Since 
the main concern is the time involving pastoral duties, time for personal activities will not be included in the tabulation.

It might be well to mention that the writer arose around 6:30 A.M. and retired for the night at about 10:30. Following a brisk jog, shower, breakfast, and worship he arrived at the church at approximately 8:30 A.M. There he maintained his study and performed most of his administrative work. He regularly took his daughter to the church-operated school on his way to his church office.

The context of the day under observation reveals that the writer had just ended his annual vacation a few days before. The first Sabbath service of the new year was approaching. Sermon preparation, therefore, was high on the list of priorities for the day. The activities have been grouped into eight different categories. Eleven work hours were recorded for this particular day. Table 3 provides a breakdown of how these hours were spent:

TABLE 3. - A one-day breakdown of time spent in ministerial activities of the Grand Rapids Central SDA Church pastor

\begin{tabular}{|c|c|c|c|}
\hline Activity & Total Minutes & Involved & Percent \\
\hline Personal devotions & . . & & 5.60 \\
\hline Sermon preparation. . & . . & & 18.18 \\
\hline House visit and Bible study & . & & 6.06 \\
\hline Hospital visits . . . & . . & & 14.39 \\
\hline Delivering food basket . . & . & & 3.78 \\
\hline Telephone conversations . & . & & 15.15 \\
\hline Administrative work $\cdot$. & . & & 21.06 \\
\hline Committee meeting .... & . $\cdot$ & & 17.27 \\
\hline Total 11-Hour day & 660 & & 100 \\
\hline
\end{tabular}


The thirty-seven-minute devotion began at 8:25 A.M. and ended at 10:00 A.M. During this time the pastor was diverted by four phone calls. It must be remarked that each of the calls were of a business nature and related to the ongoing ministry of the church. Each relayed a message, made a request, or discussed the church ministry.

Following the devotional, sermon preparation was attempted between 10:10 A.M. and 12:57 P.M. Of this time, 120 minutes were occupied in sermon preparation. The remainder of the time was devoted to four more phone calls. A total of eleven phone conversations consuming one hundred minutes were held by the pastor throughout the day. In addition, a number of calls were received by his wife at home. Among these calls was a request from one of the elderly members that the pastor deliver a food basket to another member who was in need. Since no other transportation was available, the pastor was the logical one to care for this matter, which he gladly did on his way home to lunch. The phone call took about five minutes and the delivery approximately twenty-five minutes. Two long-distance phone calls made arrangements, for future appointments. Considerable administrative and spiritual ministry was conducted by telephone on the day under consideration.

The administrative aspect of the pastor's work was the largest single segment of activity reported--a total of 139 minutes or 21 percent of the eleven-hour day. Moreover, it should be noted that administrative work would usually include the telephone and committee activities as well. When all three of these segments of 
administrative work are combined, a total of 353 minutes, or 53 percent, of the eleven-hour day falls into the administrative category. of course it is granted that not every day would see the pastor involved in this much administrative activity. However, modern pastors generally spend about half of their time in administration and organization. At the same time, according to study referred to earlier, ${ }^{1}$ they least enjoy this aspect of their work.

Following a similar plan of combining certain activities that are related in nature, it appears that hospital visiting and house visiting fall into a similar category. By doing this a tota1 of 135 minutes, or 20.45 percent of the work day, was involved in hospital chaplaincy and Christian nurture.

To summarize, it appears that during the twenty-five day period surveyed, the writer spent approximately seventh-five hours per week in ministerial activity of some kind. This is nine hours more than his Episcopal parish priest counterpart spends at his work, according to the study referred to above.

As stated earlier there may be many reasons why a pastor spends so much time in his work. Of course most pastors would like to feel it is because of their devotion to their calling, and time is of little consequence as long as it is used for God and His cause. This, no doubt, is the primary cause for working long hours, often at very demanding tasks. However, there could be other motives of a lesser quality involved. Among these could be

\section{$1_{\text {Blizzard, "The Minister's Dilemma," The Christian Century }}$} Apr11 25, 1956, p. 509. 
the pastor's inability to let go, a compulsion for grasping all the work into his own hands. Also there is the pastor's false belief that he is physically invincible and that the body and mind need but very little relief from the demands of the work. It may be the lack of competence in delegating authority and letting others carry more of the burden of the work. By looking more specifically into his own life and his relationship to work and life in general, the writer sought for answers to the above questions. These questions will be covered in the next section of this chapter.

The Pastor as the Focal Person and Role Receiver Identified

In order to accurately determine what to expect of the pastor, adequate knowledge about him must be obtained by some reliable means. It is important that he should know himself and that the congregation should have at least limited access to the information available about him. He thus will be able to negotiate himself in his role more effectively. However, this will require complete openness on his part toward himself.

Among the questions that will need answering are the following: Who is he? What has been his work experience? What is his self-image? How does he see himself? With what concepts does he approach his work? In what theological framework does he think and act? What are his aspirations for himself? What are his personality strengths and weaknesses? The 1ist could be extended. It will be to the advantage both to the pastor and his congregation to have 
accurate answers to most of these questions. This will require selfexamination on the part of the pastor. It will require a high degree of honesty as we11.

Concerning Self-examination

Some may object to such a close examination of oneself. The objection is given that too much "looking within" might lead to neurotic introspection, especially if the tendency is already present. However, it should be observed that if such neurotic tendencies do exist, the sooner the pastor is aware of them the better. What is proposed here is self-knowledge which can only be obtained through a certain amount of self-examination.

Both the Bible and other Christian writers, including Ellen G. White, give straightforward counsel concerning self-examination and self-knowledge. The Bible encourages self-examination on the part of all the followers of Christ. The Psalmist declares, "I will take heed to my ways" (Ps 39:1). Jesus cautioned His disciples in Mk 13:9, "Take heed to yourselves," when informing them of certain trials that lay ahead of them. Self-deception was a concern of the Apostle Paul as he told the Corinthians, "Let no man deceive himself," (1 Cor 13:8). The remedy for this, according to the Apostle, is self-knowledge and self-examination. "Let a man examine himse1f," he says in 1 Cor 11:28. Also in 2 Cor 13:5 he urges, "Examine yourselves, whether ye be in the faith; prove your own selves. Know ye not your own selves, how that Christ is in you except ye be reprobates." 
Among the ministers as well as lay persons of the Seventh-day Adventist church, the writings of Ellen $G$. White receive special attention on any given topic. This author especially emphasizes the importance of self-knowledge and self-examination on the part of ministers in the church. A number of references may be found in her writings. A few are quoted here to show the pointedness of the counsel. Specifically writing to ministers, Ellen G. White states:

To men to whom God designs shall fill responsible positions He in mercy reveals their hidden defects that they may look within and examine critically the complicated emotions and exercises of their own hearts, and detect that which is wrong; thus they may modify their dispositions and refine their manners. . . God would have His servants become acquainted with the moral machinery of their own hearts. 1

Not only are ministers included in this counsel but so also is every follower of Christ. "Every follower of Christ should daily. examine himself, that he may become perfectly acquainted with his own conduct. There is with nearly all a neglect of self-examination." 2 Thus, "To know oneself is great self-knowledge. True self-knowledge leads to a humility that will open the way for the Lord to develop the mind, and mold and discipline character." 3

It is to comply to some degree to the above counsel and provide a basis for negotiating openly with his role set that the writer presents the following section. The writer will disclose information that some may consider private. However, most of the information will be set forth descriptively without conclusive

\footnotetext{
${ }^{1}$ White, Testimonies for the Church, $4: 85$.

${ }^{2}$ Ibid., $2: 511$.

3 Ibid.
} 
interpretation, except where the writer deems it necessary. Following a brief biographical sketch, work experience, and theological frame of reference in which he does his work, the results of certain psychological and other tests will be disclosed. This is an attempt to obtain a profile of the pastor as he is at this point in his life.

\section{A Brief Biographical Sketch}

The writer was born on a farm in western central Illinois, October 27, 1922. Along with his exposure to all the facets of farm life he spent his first twenty years attending schools in rural and small town centers. Being oriented to farm life, he considered that occupation when setting his goals in life. However, all this changed when providences led him into the U.S. Navy, overseas service, and eventual conversion to Jesus Christ in 1945. From then on his steps led him more and more toward the gospel ministry. Late in the year of 1945 a second spiritual crisis took place in his life which led him into the Seventh-day Adventist church. Following his discharge from the Navy in February of 1946, he was baptized into the Seventh-day Adventist church. He worked with his brother on the home farm until September 1946, when he began his first denominational service as a literature evangelist. A year later he enrolled at what was then known as Emmanuel Missionary College, now Andrews University, and graduated in June of 1951 with a Bachelor of Arts degree in religion.

In 1948 the writer married Alma Cummings, also of Illinois, whom he had met in connection with his literature evangelistic 
work. Three daughters were born to them. At the present only the youngest remains at home since the two oldest daughters are married.

Work Experience and Employment

Upon graduation from college in 1951 the writer was employed by the Illinois Conference of Seventh-day Adventists as an assistant publishing director of student colporteurs. Later that same year the Illinois Conference employed him full time as an assistant to a senior pastor doing evangelistic work. Four months later he was assigned to pastor a three-church district in western Illinois. He remained in the Illinois conference as a pastor of a number of small churches until 1964, except for a two-year absence while attending the Seventh-day Adventist Theological Seminary. In 1964 the Michigan Conference invited him to serve. as pastor of one of the suburban Detroit churches, where he remained until 1966. In 1966 he accepted a position in an overseas college teaching theology which he filled for six years. Further education drew the writer and his family to Andrews University in 1972. He then enrolled in the Doctor of Ministry program when it was first offered by Andrews University in June 1973. During his work toward the Doctor of Ministry degree he became the pastor of the Grand Rapids Central Seventh-day Adventist church, which has already been identified as one of the foci of this study.

The Writer's Theological and Working Frame of Reference

The beginning pastor's concepts of the ministry and his philosophies concerning it develop rapidly in the first few years 
of his work. These concepts often change as the pastor matures when he grasps the magnitude of the task he has undertaken. With due respect and regard for the formal training received during his college days, the writer is impressed that he was inadequately prepared for what became his work as a pastor. In conversing with others of his peer group, he finds he is not alone in this impression. What was lacking in formal training and knowiedge was made up in enthusiasm and youthful zeal, as is so often the case with beginning ministers.

A careful observer may learn a great deal about the ministry from the context of the work itself. As an example, the writer had only been a member of the church one and one-half years before attending college to prepare for the ministry. The first board meeting he recalls attending was after he had left college and had entered the ministry. Four months later he was a full-fledged pastor of three churches and was expected to serve as chairman of three church board meetings. One might reason that learning how to conduct board meetings is more caught than taught, and this may be partially true. However, with no reflection on those in charge of training young men for the ministry in those days, very little instruction was given in the art of conducting board meetings or many other of the routine duties which are a part of the minister's work in the local church.

The writer's concept and philosophy of ministry grew out of his own understanding of his denominational Christian heritage, his study of theology, and the community and local church traditions 
of which he is a part. One bit of advice given by two conference officials proved to be somewhat of a base from which the writer sought to direct his ministry. Early in his first pastorate the writer was visited by these men for business purposes and one made the suggestion that the writer should try to conduct a well-balanced ministry. The implication seemed to be that if the pastor meets the goals and deadlines of the conference and the demands of his parishioners, as well as those of himself and his family, he should enjoy a successful ministry. Also implied was that one's effectiveness in the ministry is determined by the degree of his ability to engage effectively in a wide range of activities presenting themselves in the pastorate. This counsel, coming from highly respected men, was received as good counsel, and an attempt was made to implement it from the beginning.

Since graduating from college in 1951 the writer has spent seventeen years in the pastorate, six years in teaching theology, and three years pursuing advanced degrees at the Seventh-day Adventist Theological Seminary. As pastor or as assistant pastor, he has been associated with twenty-four congregations during this period of time. His average length of stay as a pastor in any one pastorate has been nearly two years. His longest stay in any one pastorate was two years and nine months and his shortest was one year. This average stay in the pastorate may be less than normal, but it appears to be the pattern of many of his colleagues. The writer would be the first to admit that the moves took place too frequently and that the length of time in any one pastorate was 
too short. However, at the time he entered the ministry, Seventhday Adventist pastors seemed to move more frequently than in recent years.

Concerning the frequently moving pastor. The reasons for pastoral transfers are as varied and intriguing as the people Involved. The most common reason is the opportunity for so called "advancement" in the denominational hierarchy of positions. This, coupled with the desire to find a more suitable position to fit one's particular abilities, probably accounts for the majority of pastoral transfers. A number of pastors are transferred into nonpastoral positions in the denominational work system. Many move from the pastorate into teaching, chaplaincy; conference administration, and departmental positions. While no statistics are available within the Seventh-day Adventist church as to the number of pastors transferring into nonpastoral positions, some statistics are available from other denominations.

Ex-pastors and those who move into nonpastoral positions tend to have shorter stays in local pastorates. According to one study as to why men leave the parish ministry, it was found that expastors "have a stronger pattern of early changes than pastors in denomination, in career, and in jobs." 1 Furthermore it was found that reasons for leaving the pastorate include "personal crises, a sense of inadequacy, disillusionment and frustration with the church, inability to relocate when necessary, family problems, and

${ }^{1}$ Gerald J. Jud, Edgar W. Mills, Jr., and Genevieve Walters Burch, Ex-Pastors: Why Men Leave the Parish Ministry (Philadelphia: The Pilgrim Press, 1970), p. 59. 
attractive work opportunities." 1 . The study reveals the frequent moves among pastors is not so much a dropout crisis but more of a mobility and morale crisis in the ministry. Also it notes that those pastors who enter secular employment do not consider themselves ex-ministers in that they have merely enlarged their understanding of their vocation to include so-called secular professions. $^{2}$

Whatever the reasons for frequent pastoral moves may be, it is likely that the short-term pastorate is not as effective as it could be in practically all aspects of ministerial concerns. The writer has observed that pastoral moves within the Seventh-day Adventist denomination are determined to a great extent by the pastor-evangelist concept of the Seventh-day Adventist minister. ${ }^{3}$ He is not just a pastor, he is also an evangelist. Furthermore it appears that Seventh-day Adventist ministers are amenable first to their conference employing organization and that they are to hold themselves available at all times to serve at any.place the organization should direct.

However, the writer has further observed that the older and more experienced a pastor is the less likely the conference officials are to Impose their will upon the pastor contrary to his own wishes. The approach to move is more by invitation. On the other hand, the younger and less experienced a pastor is the more likely it is

\section{$1_{\text {Ibid. }}$ \\ ${ }^{2}$ Ibid.}

${ }^{3}$ General Conference of SDA, "Evangelism and Finishing God's Work," paper presented to the Annual Council, 13-21 October, 1976. (Mimeographed.) 
that he will be asked to transfer. He, of course, would likely respond favorably due to his desire to develop a high level of confidence in him on the part of his employers.

Since leaving college in 1951 the writer has made fourteen moves. Only three of the moves were made on his own initiative and those were to obtain advanced training at the theological seminary. The remaining eleven moves were initiated by his employing organization or another organization that wished his services. In practically every instance, however, the offical who made the contact permitted the writer to make the decision as to whether he would care to move. In his earlier experience it appeared that the heat was stronger than the light at times. However, he has never felt unyielding external compulsion in any of his moves from pastorate to pastorate or from pastoral to nonpastoral positions. Finally, among other reasons the frequently moving pastor may reflect a poor picture of himself. His self-knowledge may be distorted and limited. He may not have a good self-image and feel inadequate about his competence as a minister. This may reflect itself in restlessness followed by a desire to move and begin over again in a new setting.

This points up the importance of knowing oneself as a pastor and being satisfied with that knowledge. It is with this concern to which the next section of this chapter is devoted. How does a pastor go about determining his strengths and weaknesses, his competencies and incompetencies? What tools are available for 
this purpose? As will be seen ample help may be obtained concerning these matters.

Personality and Vocational Profile of the Focal Person

In this section the concern is to present the self-assessment of the focal person or the pastor. To obtain as accurate selfknowledge as possible, the writer arranged a two and one-half day visit to the Midwest Career Development Center in Columbus, Ohio. Four of the total of six tests were taken there and two additional tests were taken in connection with the Doctor of Ministry coursework at Andrews University. Of the six tests three related to personality, one with concept mastery or intelligence, one involved conflict management, and one surveyed vocational interest. The two and one-half days at the Midwest Career Development Center were during the month of October 1974, near the end of the writer's first year in the Grand Rapids pastorate. The four tests taken at that time were Strong-Campbell Interest Inventory, Myers-Briggs Type Indicator-Form F, Concept Mastery Test-Form T, and a Personal Orientation Inventory. The program at the center is explained in some detail in a letter by the staff. ${ }^{1}$

Although a variety of benefits are available to the clients who attend the center, the chief contribution ta the writer came from the tests that were taken and the consequent results with the interpretations provided by the staff.

${ }^{1}$ See appendix $C$. 
The two tests taken at Andrews University were administered as follows: The Conflict Management Survey was taken in connection with the Doctor of Ministry course in church administration, during the winter quarter of 1974. The 16PF personality profile test was taken January 17, 1977. The results of these tests taken by. the writer will be presented under the headings of personality, concept mastery, conflict management, and vocational interests.

Tests involving personality. The $16 \mathrm{PF}$ test was taken most recently: It was administered by Dr. Eldon Chalmers, Clinical Psychologist and Professor of Pastoral Care, Seventh-day Adventist Theological Seminary, Andrews University, Berrien Springs, Michigan. It is a test designed to rate the client on sixteen major personality traits for adults. The standard of measurement in this test is on a scale of one to ten, with five and six considered average.

According to the one administering the test, the 16PF test is considered to be one of the most accurate of personality tests available. By taking both sections of the test the degree of accuracy is somewhat increased. Both sections were taken by the writer.

The profile resulting from this test revealed both positive and negative traits to the writer. On the positive side he rated average or slightly better on twelve of the sixteen traits. He rated slightly below on four of the traits.

The writer was rated eight on the ten point scale in his A and $B$ factors involving his attitudes and relationships with others. This discloses him as higher than average in being outgoing, 
warmhearted, and intelligent in terms of abstract thinking. His C factor rated him to be at four on the ten point scale indicating that he is affected by feelings somewhat with a slight tendency toward low ego strength.

He registered at three on the scale concerning humility and docility, factor $E$, which is lower than average and might be considered a positive trait. He also registered three on the $\mathrm{F}$ factor which implies he has a serious attitude toward life.

The writer rated average on the G factor which measures conscientiousness. He also ranked average on the $\mathrm{H}$ factor being equally balanced between shyness and venturesomeness, but shot up to eight on the scale toward being tender-minded and sensitive. As will be seen, this may reflect a slight tendency toward introversion. Most ministers, according to the psychologist, rate high in tendermindedness and sensitiveness.

He rated slightly better than average as a trusting person. The test rated the writer about equally balanced between being practical and imaginative. He reflected a little above average amount of apprehension, self-reproach, and insecurity (seven on the ten point scale). However, his Q1 factor, which was also seven on the scale, revealed him as experimenting, free-thinking, and liberal. This might help to offset his apprehension, selfreproach, and insecurity.

The writer was equally as balanced between the need for being group dependent and being self-sufficient. The same balance was maintained for being self-controlled and undisciplined. 
Finally, factor Q4 revealed a trait indicating that, at the time, the writer was tense and frustrated, driven and overwrought. The clinical psychologist gives assuracne that this may be lowered by following some simple rules for a few weeks--a program the writer is currently observing.

In summary, the writer obtained a clearer picture of himself through the $16 \mathrm{PF}$ test. It provided helpful personal insights to strengths and weaknesses and an encouragement to improve in the days to come.

A personal orientation inventory was taken by the writer at the Midwest Career Development Center, Columbus, Ohio, on September 29, 1974. The inventory consists of a number of paired statements. The client is asked to choose which of the statements most applies to himself. It is therefore, an inventory of oneself.

Even though certain changes in attitude may have taken place within the writer since the test was taken, it appears that some of the same weaknesses were revealed then as was apparent on the 16PF profile. A brief look at the P.O.I. profile sheet discloses that the writer was very low in his $T_{c}$ factor (time competence) at that time. According to the counselor he was living either in the past or the future and not very much in the present. The counselor pointed out that this may also have influenced the low $\mathrm{C}$ factor Involving warm interpersonal relationships because the writer would not be quite present in his feelings. At that time he also showed a low self-perception and some difficulty accepting himself 
in spite of known weaknesses. He was somewhat rigid in his application of values, which is perhaps somewhat normal for his profession.

On the positive side he was above average on five of the twelve factors. He was average in his inner directedness and selfactualization. He rated well in being sensitive to his own feelings and needs, and he also revealed an ability to express his feelings. He came out positive in his ability to see the opposite viewpoint as having some value. He revealed an ability to accept feelings of anger and aggression. It appears that the inventory supports some of the same positive aspects as did the 16PF profile test. The Myers-Briggs Type Indicator - Form F test was also administered at the Midwest Career Development Center. It was taken on Qctober 7, 1974. It is concerned with the difference in personality that results from the way a person perceives and the way he judges or organizes. Perception takes place through the senses and through intuition, whereas judging or organizing takes place through thinking and feeling. This determines personality type. A personality type grows out of the kind of perceiving and the kind of judging process persons prefer and how they use them. Four pairs of combinations are provided as a criterion for evaluating the client's results. They are extroversion and introversion; sensing and intuition; thinking and feeling; judging and perceiving.

The results of P.O.I. taken by the writer reveals that he prefers the judging, feeling, intuition, and introversion approach to life. A closer look at each of these shows that in judging the 
writer approaches life in a planned, wel1-ordered way and aims to regulate life and control it. His feeling indicates he is sympathetic and "feels" that human likes and dislikes are more important than logic. He was about equally inclined to sensing as to intuition as a means of perceiving things. His primary intuitive approach indicates that he values imagination, inspirations, and possibilities and is good at new ideas, projects, and problem solving. On the other hand his secondary sensing way inclines him to be practical and realistic. Finally his favorite process involving introversion indicates that he likes to reflect before acting and think before speaking and drawing conclusions.

Perhaps of all the tests this more specifically points out the direction the writer ought to go in terms of his work life. His particular type prefers the intuition and feeling approach to 1ife. They focus their attention on possibilities and handle these with personal warmth. They thus tend to be enthusiastic and insightful and find their scope in research, teaching, preaching, counseling, writing, or psychology.

A test involving academic intelligence. The Concept Mastery Test was also administered at the Midwest Career Development Center. It was taken by the writer on October 8,1974 . It is divided into two parts. Part $I$ involves synonyms and antonyms and part II analogies.

While not an I.Q. test the Concept Mastery Test measures the intellectual level of the client. He is compared with others of the same profession and educational level. The writer was 


\section{2}

compared with the graduate student educational level. He registered slight1y lower than the average graduate student who had taken the test at the Midwest Career Development Center.

The implications to the writer were explained by his counselor at the center. It was felt that the writer has potentials for graduate work and could fill the professional positions of pastor and teacher of theology without intellectual embarrassment. A test involving conflict meanagement. The Conflict Management Survey was taken in January 1974. This survey is based on the premise that one's view of conflict and his consequent predisposition to handle conflicts in certain ways are more important determinants of conflict outcomes than the nature of the conflict itself. The survey is designed to provide information about the manner in which individuals react to and attempt to manage differences between themselves and others. It identifies styles of conflict management which include personal, interpersonal, small group, and intergroup.

The survey measures five different styles of relating to conflict. The $9 / 1$ style is characterized by win-lose, in other words the emphasis is on personal goals to the virtual exclusion of any concern for personal relationships. The $1 / 9$ style has as its dominant conflict management style the concern for the effect of the conflict upon the well being of his relationships. He seeks to appease others by ignoring, denying, and otherwise avoiding conflict. The $1 / 1$ style is inclined to hopelessness in times of conflict, or a lose-leave style. The person tends to leave the conflict psychologically if not physically. The $5 / 5$ is a compromise 
style including a little bit of winning coupled with a little bit of losing. It of ten results in a climate of suspicion among parties to the conflict.

Finally the $9 / 9$ conflict management style attaches major importance to goals of those involved in the conflict along with the well being of the relationship. Differences are confronted in a problem-solving way. It rests on the assumption that a working through of differences may lead to a more creative solution of both personal and interpersonal problems than could be achieved by any single person.

Graph 1 indicates the styles of conflict management the writer used most at the time the test was given. It shows that the $1 / 1$, or lose-leave style, dominated the writer at that time. As noted above, in this style the person tends to leave the conflict psychologịcally, if not physically, to avoid being caught up in endless struggles which he feels he cannot win.

It is also important to observe the backup styles that the writer most commonly turns to when his dominant style is not acceptable. The writer, at the time, used acceptably both the $9 / 1$, or win-lose style, and the $1 / 9$, or yield-lose style. There was a slight favoritism shown towards the $1 / 9$, yield-lose, as the writer's backup style of facing conflict. This reflects a concern on his part for preserving the relationship.

The writer's use of the $5 / 5$, compromise style, was shown to be sufficiently strong in personal and small-group situations, but weaker than desirable in interpersonal and intergroup 

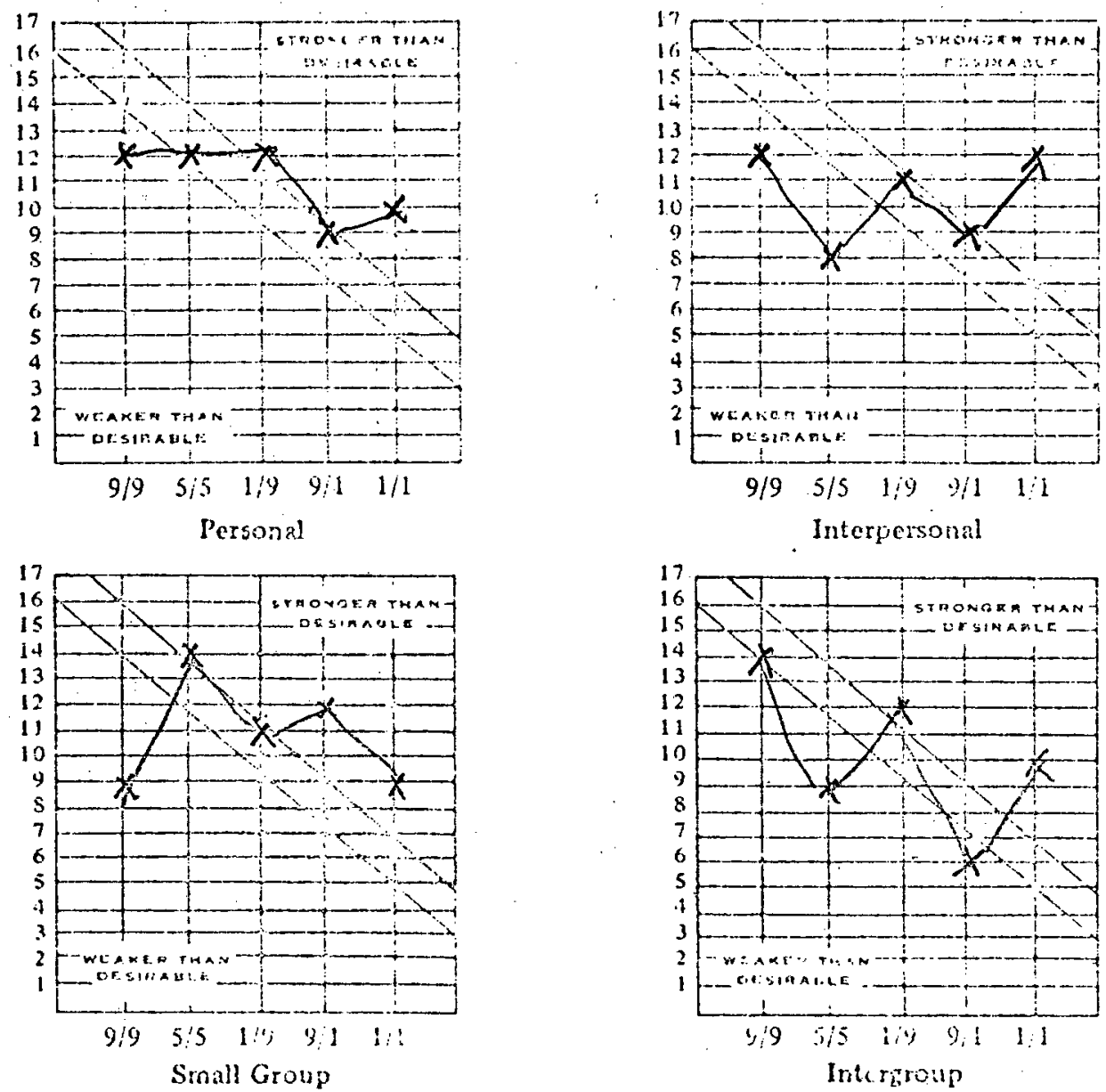

Fig. 1. Four graphs concerning personal, interpersonal, small group, and intergroup conflict management by the focal pastor.

situations. Finally, except for intergroup-conflict situations, the writer revealed a weaker than desirable use of the $9 / 9$, problemsolving style, in all of the other situations pictured in the graphs.

In summary, the writer was made aware of a tendency to flee conflict situations. If the conflict does not go away he is inclined to yield rather than jeopardize his relationship with others. It appears there is a need for him to strengthen his negotiative skills in his management of conflict situations. This is pertinent 


\section{5}

information in view of 1 ts importance in negotiating for a more fruitful ministry.

A test involving vocational preference. The Strong-

Campbe11 Interest Inventory was taken in connection with the writer's visit at the Midwest Career Development Center, October 4, 1974. It is used to show one's work interests in a general way and to show the kinds of work in which he would be comfortable. It reveals work areas of the client that match those of other employed people. It measures interests and not abilities. Because of its significance in terms of this project it will be discussed with a view to determining a course of action for the future.

Three sets of scores are presented to the client in his inventory report. The first set give a general overall view of the client's interests. The second set reveals basic interests within specific areas such as sales, music, or mechanical. The third set is designed to disclose how similar or dissimilar one is to employed people in various occupations such as artists or mathematicians.

1. The writer ranked highest in the first set of scores with conventional type work preferring jobs in which he is fully aware of what he is supposed to do and which involve the use of verbal and numerical skills that characterize office work. He identified with people who fit well into large organizations but do not seek leadership. Such people describe themselves as conventional, stable, well-controlled, and dependable. They are most effective at well-defined tasks, and they value material possessions and status. His next highest occupational theme was the $\mathrm{S}$-theme, 
or social. Such people are sociable, responsible, and concerned with the welfare of others and human problems. A third theme that was very near to the social theme for the writer was the R-theme, or realistic theme. Such people are rugged, practical, and physically strong. They like outdoor work and working with tools.

In summary the writer ranked from highest to lowest the six categories of occupational interests in the following order: conventional, social, realistic, investigative, artistic, and enterprising.

2. The second set of scores concerned basic interest in pure types of work. They reveal areas in which one would find satisfaction or dissatisfaction. The higher the score the more likely one would identify and enjoy that type of work, and the lower the score the less likely he would enjoy that type of work. The writer did not. identify very highly with any activity, but was somewhat high in four and average in. sixteen activities. As might be expected he was highest in religious activities but; to his surprise, military activities followed. Social service and office practices were much less of a surprise.

From this the writer would identify with people working in the religious field, particularly directors of Christian education, priests, and ministers. He also would identify somewhat with a military officer, police officer, or an airplane pilot. As a social worker he would be comfortable as a social worker, guidance counselor, or minister. 
3. The third and final set of scores represents occupational scales of similarity or dissimilarity. These scores indicate the degree of similarity between the writer's interests and those of employed people who are of the same sex. The results show the writer identifies with college professors, priests, and ministers.

Finally, the printout stated that the writer's academicinterest indicates a similarity of interests with people who go to college and obtain a baccalaureate degree, such as teachers and nurses. His introversion--extroversion score was average with a slight preference for working with people.

To summarize what the Strong-Campbell Inventory is saying to the writer, it appears that the combination of interests should cause him to consider work that involves teaching in a well-ordered environment in which concern for people is important. He would also be satisfied with the ministry, but might experience a higher degree of stress because of certain tendencies revealed in other tests described earlier. Because one cannot perform equally well in every occupation, the benefit of knowing where one can find greatest satisfaction is extremely important.

Most of the tests speak for themselves and a fairly clear picture of the writer has been disclosed. Much more might be said but is not pertinent to this study. Because of the personal nature of this section it is hoped the reader will treat with charity that which has been disclosed. Suffice it to say it has been an attempt to comply with the admonition to examine oneself. 
$\underline{\text { Summary }}$

In this chapter an attempt has been made to present a verbal picture of a specific church, city, and conference. These collectively are the major role senders to the focal person of this study. There has also been an attempt to describe the position along with a brief study of the amount of time involved in the position based on actual records kept by the writer. Finally, the writer as the pastor has been described. Included in the description of the pastor was a biographical sketch, work experience, theological and working frame of reference, and the results of a battery of personality tests, surveys, and inventories that were taken in anticipation of this study.

The purpose of this chapter describing the role set has been to provide helpful knowledge for the negotiating process for a more effective ministry. What has been found that will be useful in this process?

First, the geographical location may have some effect upon the expectations of the pastor. As a northern city in the Midwestern part of the United States, Grand Rapids reflects a strong conservative religious culture. As compared to other cities of its size in which the writer has served as pastor, there seems to be a greater religious influence than is evident in most other cities. As a "city of churches" almost all types of religious groups may be found there. The stronger religious groups appear to be among the conservative, Protestant variety. The Grand Rapids Central Seventhday Adventist congregation reflects much of this conservatism, 
variety of backgrounds, and religious culture. Such a picture has implications for the pastor.

Secondly, the pastor's position provides a wide variety of opportunities for him to exercise his pastoral skills. He may function as a leader of pastors, preacher, teacher, chaplain, administrator, organizer, counselor, and community relations director. To fulfill all these roles the pastor will need to know how to manage his time.

Finally, the pastor, as the focal person, found himself to be within the normal range of humanity. However, there were some variations, which, of course, help to make up this normality. These will need to be considered in any negotiative setting in which he is involved. A few of his dominant qualities include his ability to relate well to others as friendly and outgoing, his seriousness with life, his sensitivity to others (and himself), his tendencies toward being trusting and accepting, socially aware, experimentative, self-reproachful, and driven. He enjoys equally working alone or with others. In time of conflict he tends to prefer to leave and lose rather than to negotiate. He tends to identify vocationally with those in the ministerial profession or with college teachers.

The question that is now of concern is how would this person meet the expectations of the role set involved in this study? To determine this the pastor must gain deeper insights as to just what does the role set expect of him. What attitudes must he manifest? How much time is he expected to spend in his work? What 
procedures or methods are preferred in his approach to his work? These and other equally importanit questions must be answered as clearly as possible before the pastor is able to enter into the negotiation process. It is to the analysis of the expectations expressed by the role set in response to the survey form that the next two chapters are devoted. 
CHAPTER V

THE RESPONSES OF GROUPS TO THE SURVEY AND AN ATTEMPT TO ANALYZE THE RESPONSES TO SECTIONS I AND VIII CONCERNING ADMINISTRATION AND TIME

In chapter IV an attempt was made to identify the major divisions of the focal pastor's role set. These include the Grand Rapids Central SDA congregation, the Michigan conference officers, and committee members. Also a profile of the pastor was given.

The study is designed to provide specific information about a specific church and its pastor with a view toward negotiating a more effective ministry. It is an attempt to be as open as possible to make the negotiating process more meaningful.

This chapter begins to analyze the responses to the survey instrument, or questionnaire. It introduces the various subgroups as they identified themselves in their responses to the introductory questions of the instrument. This chapter will also provide an analysis of section $I$ of the survey form which concerns administrative and organizational expectations. The chapter will conclude with an analysis of section VIII of the questionnaire which concerns time expectations of the pastor.

The balance of the survey analysis will be presented in chapter VI. Part II of the questionnaire, concerning leadership 
style, will not be treated independently, but the issues involved will be introduced as they supply pertinent information to the other sections under consideration in this study:

An Analysis of the Responses of the Subgroups to the Survey

The plan of this study was to survey the Grand Rapids Central Seventh-day Adventist congregation, the Conference Committee of the Michigan Conference of Seventh-day Adventists, and certain former pastors and assistant pastors who have served the congregation. It was believed that a total survey of the entire church membership would provide a better picture than limiting the survey to either random sampling or a select few. Every member of the church except those living too far away to attend the services in Grand Rapids was included in the survey. Approximately five hundred copies of the survey form were mailed out to the various groups on September 22, 1976.

Total Response

In order to identify three specific groups a color code - system was devised. It was decided to send pink questionnaires to the conference committee and ministers, yellow to church officers and deacons, and white forms to the nonofficer laity. Approximately 430 copies were sent to the nonofficer laity, forty copies were sent to the officers and deacons of the church, and thirty to the conference group. 
By January 1, 1977, 213 copies of the survey form had been returned. A self-addressed stamped envelope had been enclosed with the form. Except for a few public announcements during the Sabbath worship hour, there was no further communication with the recipients of the survey form.

The 213 forms that were returned represent 43 percent of the total sent out. A total of 190 of the respondents were members of the congregation and twenty-three were conference employees. Three responses were from the pastor and his family and are treated separately. Responses from the various color coded groups are reflected in table 4.

TABLE 4.--Number of responses from the congregation and conference

\begin{tabular}{|c|c|c|}
\hline $\begin{array}{l}\text { Group of } \\
\text { Respondents }\end{array}$ & Number & Percent \\
\hline Responses.. & 213 & 100 \\
\hline Nonofficer laity & 167 & 78.40 \\
\hline Officers and deacons & 23 & 10.80 \\
\hline Conference group ... & 23 & 10.80 \\
\hline
\end{tabular}

Responses from the Congregation

The congregation reflects a wide diversity among its members in educational, economic, and professional status. This tends to make a more heterogenous than homogenous unit. The degree of heterogeneity will be observed when the questionnaire responses are analyzed.

The strength of any congregation is reflected in the number of family units within the constituency. There are approximately 
275 separate family units in the congregation. The women exceed the men by almost two to one--63 percent females and 37 percent males. There are approximately 176 men and 299 women in the congregation.

One hundred eighty-four usable survey forms were received from the local congregation. The responses to the first question of the introductory page reveals that of these, fifty-six identified themselves as men and 122 as women. Compared to the proportion of men and women in the church slightly fewer men than expected responded and slightly more women. Possible reasons for this may have been that many men did not take the time to do it; a tendency to leave such matters to their wives, mothers, or sisters; or possibly even a simple lack of interest. Table 5 provides a clear breakdown of the number of men and women who responded to the survey.

TABLE 5.--Responding laymen according to sex

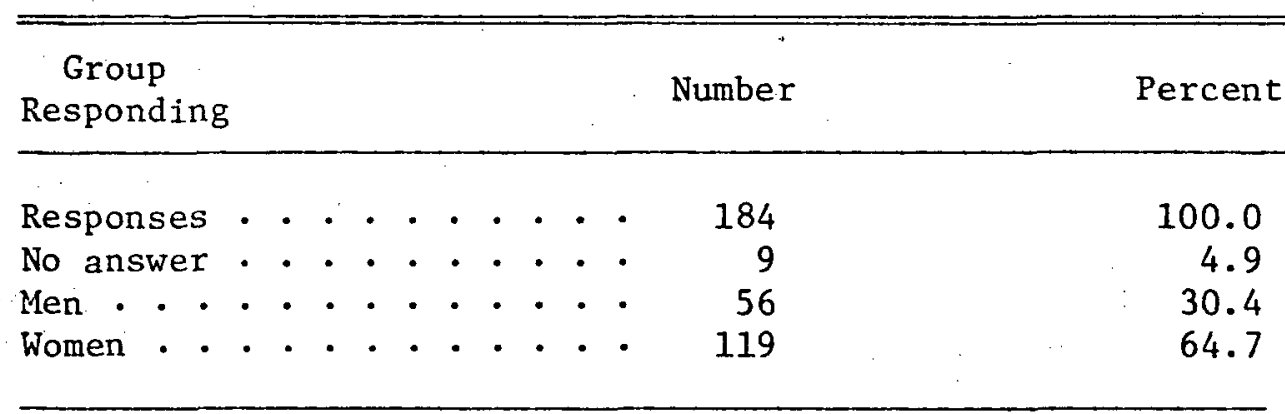

The second portion of the introductory page of the survey form was designed to elicit approximate ages of the respondents. Although no specific ages were requested the respondent was asked 
to select the age group into which he belonged. These were, less than 20 years old, 20-35,36-49, 50-64, and over 65. Table 6 reveals that of the group from the church who responded almost half of the respondents were fifty years old or older.

TABLE 6.--Responding laymen according to age

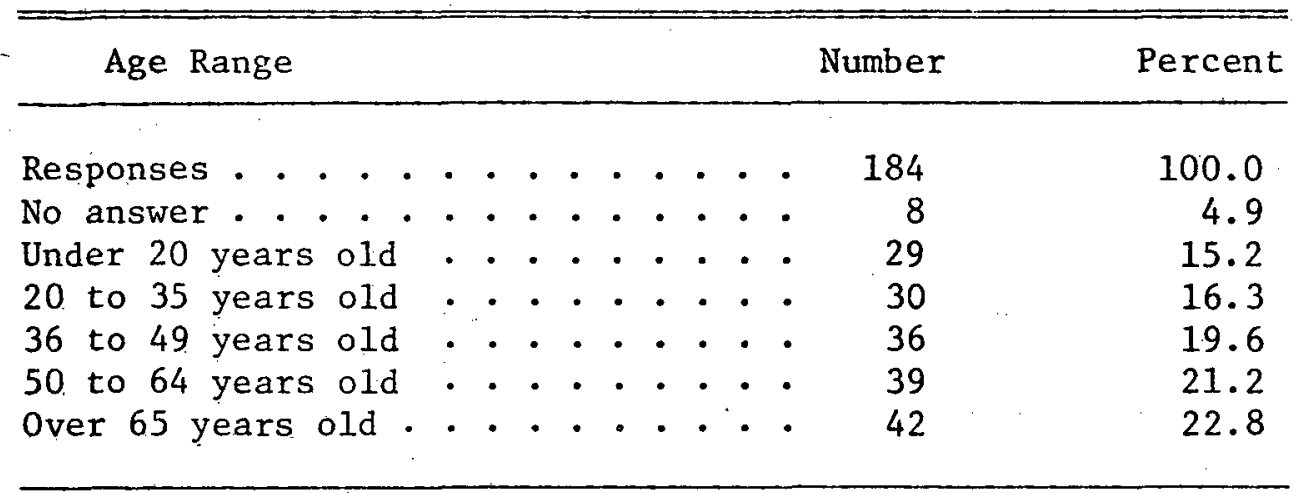

The proportion of the number of men and women in the various age groups was in keeping with what would be expected except in the under-twenty-year-old group. There were only four young men under the age of twenty that responded.

A third section of the introductory portion of the survey form was designed to determine the attendance patterns of the respondents. Five distinct categories were outlined. The respondent was asked to check the one that best fit his attendance pattern. Those suggested were: almost every week, two or three times per month, not more than once per month, less than ten times per year, or never. Table 7 reveals the pattern for the total group of laymen who responded.

An attendance pattern of two to three times per month might be considered regular attendance. By adding those who attend 
almost every week and those who attend two or three times per month one finds that 82 percent who responded attend regularly... On the other hand only 11 percent of those who responded to the survey have poor attendance patterns of the last three categories in the table, i.e., not more than once per month, less than ten times per year, or never attend. It may be concluded that those responding to this survey represent a devoted group of strong supporters for the church and its pastor.

TABLE 7.--Attendance patterns of responding laity

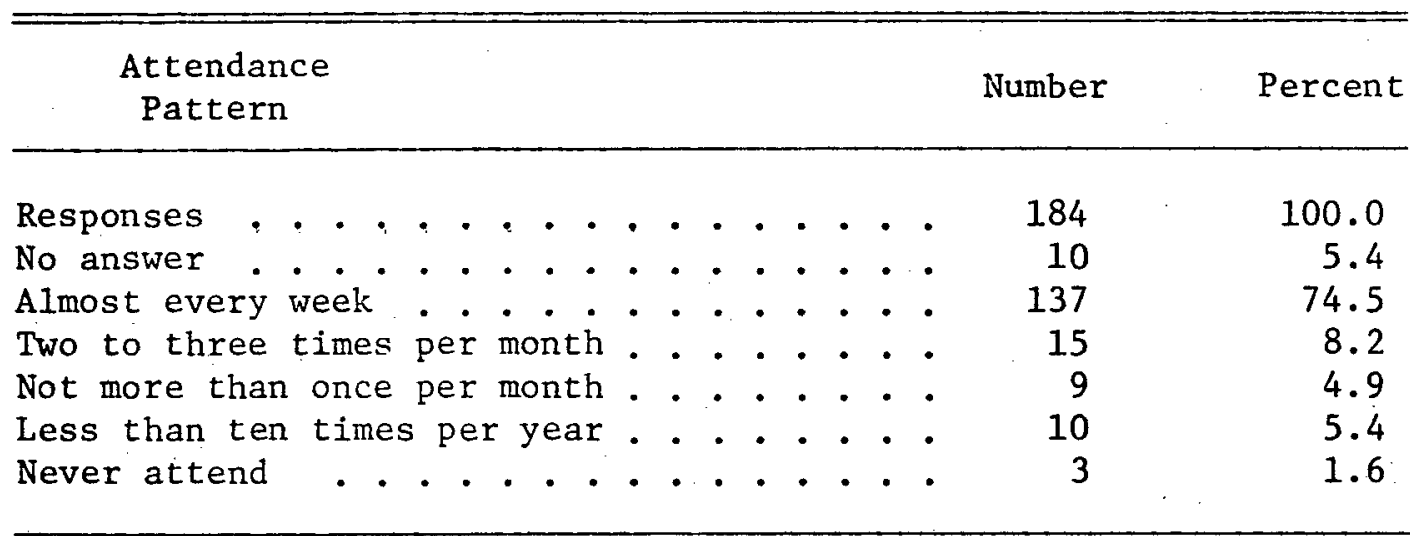

There were some variations in attendance among some of the subgroups. The men who responded appear to be less regular in their attendance than the women. Eighty-eight percent of the women attend at least two to three times per month. Only 82 percent of the men attend two to three times per month or more. The 20-49-year-old age group exceeded the under 20 and the over 50-year-old age groups in their attendance patterns. Eighty-nine percent of the 20-49-year-old age group attend regularly, 86 percent of the under 20-year-old group and 84 percent of the over 50-year-old age group attend regularly. While a conclusive trend in attendance is not evident, it appears 
that the older group have a slightly less regular attendance pattern than their youthful fellow members.

Responses from the Conference Group

This survey was planned to invite responses from the Michigan Conference officers, the executive committee, and certain former pastors and assistant pastors of the Grand Rapids SDA church. Since most of the pastors have served as members of the executive committee and therefore have an affinity with the group of conference officers, it was decided to treat them as part of the conference group when tallying the results. This conference group plays an important role in the life of the pastor and influences him considerably in his approach to his ministry.

A total of twenty-three survey forms were completed and returned by the conference group. All the respondents in this group were men. Inasmuch as these men do not attend the focal church the attendance patterns for this group is not pertinent to this study. However, the age range of the conference group may be of some interest. It is to be expected that this group would represent a fairly mature age. The approximate age of the various members is revealed in table 8.

\section{The Subgroups Identified}

The above analysis of the responses to the questionnaire Identify a number of subgroups that provide the basis for comparison in the analyses that follows. To limit the number of subgroups certain age and attendance groups were combined. Table 9 provides 
TABLE 8.--Age range of conference committee members and ministers

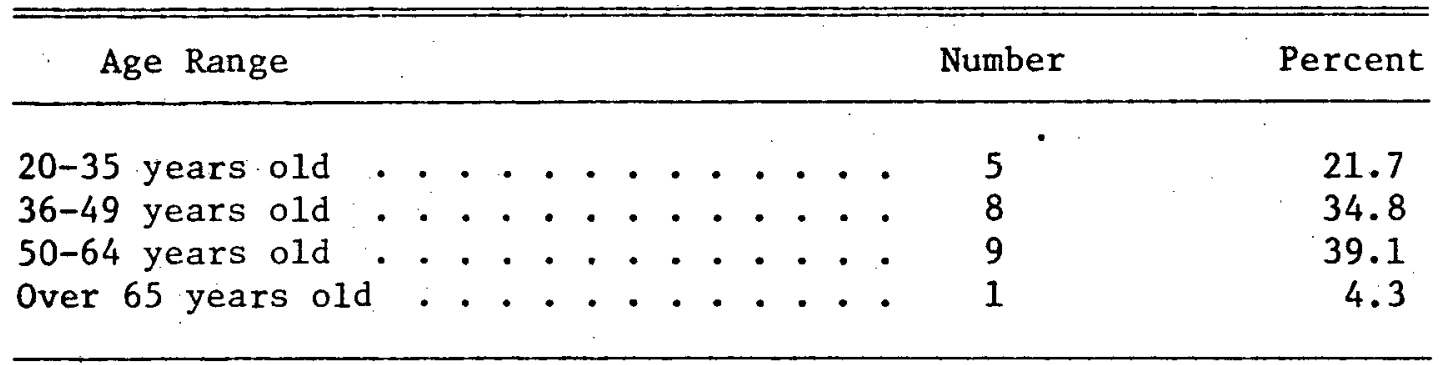

TABLE 9.--Identification and listing of subgroups

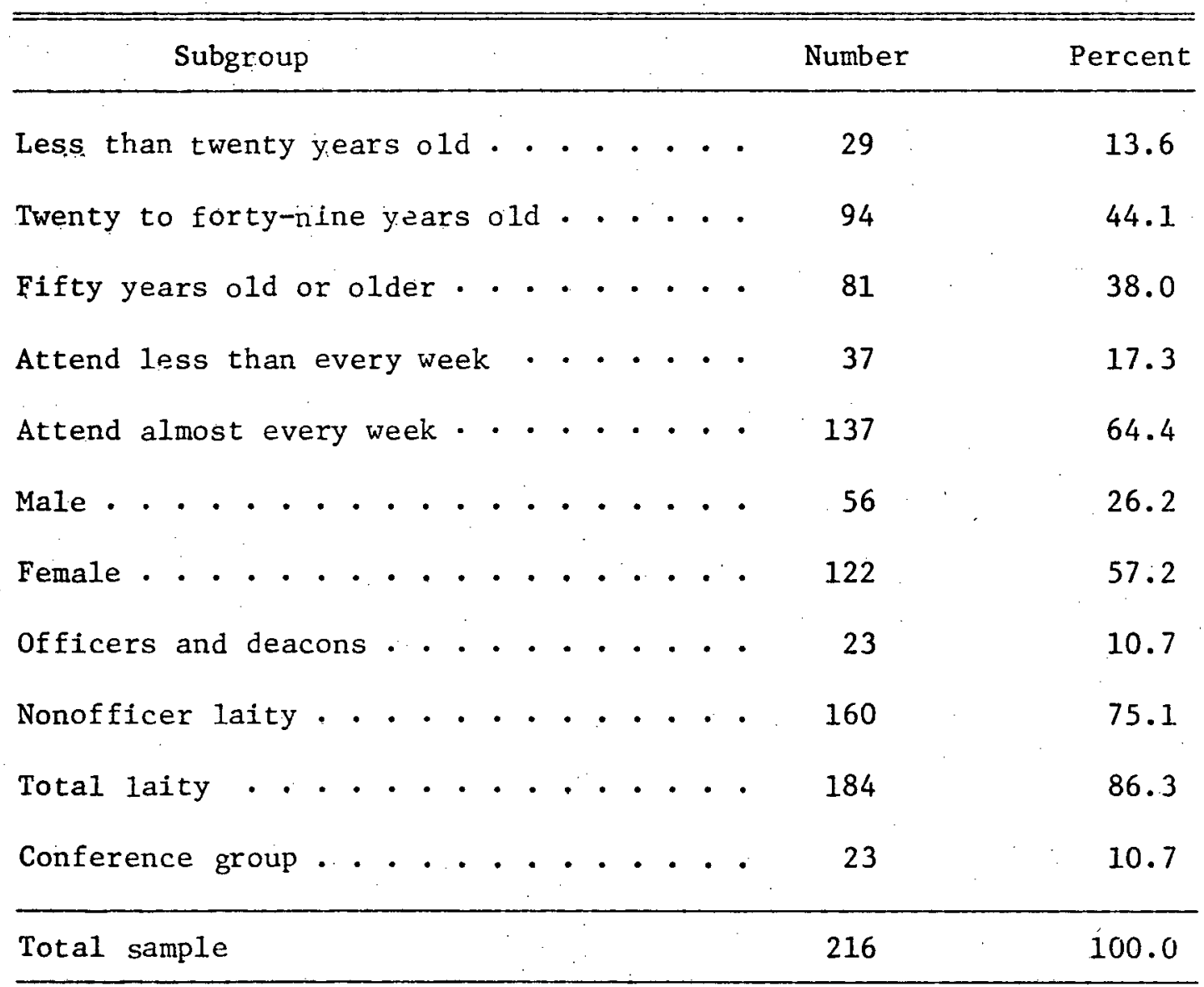


a summary of those groups that emerged from the combinations and those that naturally fall into separate categories.

A further combining of subgroups allowed for seven pairs as a basis for comparison. These seven pairs are the male/female groups; the under-fifty/over-fifty age groups; the officers-anddeacons/nonofficer-laity groups; the attend-almost-every-week/1essthan-every-week groups; the officer-and-deacon/conference groups; the nonofficer-Iaity/conference groups; and, the total laity/ conference groups. To determine the degree of difference between the pairs of subgroups a Chi-square test was applied. ${ }^{1}$

The Purpose and Plan of the Survey

The purpose of this survey is to determine the expectations of the pastor by his role set in certain areas of his ministry. It is also the purpose to determine the areas of his ministry over which significant disagreement exists between certain subgroups. The degree and intensity of preference on the part of the various groups will be observed.

The main body of the survey form is divided into two parts. The first part contains eight sections; the last part only one. The eight sections of part one of the survey form include: Administration and Organization, items 1-18; Community Relations, items 19-24; Evangelism and Outreach, items 25-29; Counseling and Pastoral Visitation, items 30-44; Personal and Family, items 45-56; Preaching and Worship, items 57-63; Teaching and Training, items 64-69; and Time, item 70 .

${ }^{1}$ See chapter I, p. 14 concerning the Chi-square test and its meaning in this study. 
The respondents were asked to check the number of their preference for each statement regarding the duties of the Grand Rapids Central SDA church pastor. Five responses were possible: 1--Absolutely must, 2--Preferably should, 3--May or may not, 4-Preferably should not, and, 5--Absolutely must not.

Part II of the questionnaire had eight questions. It was designed to determine the preference concerning the pastor's attitudes toward certain facets of his work and life. Included were matters related to personal counseling, community relations, motivation for the ministry, teaching and preaching, conflict, and leadership style. The respondent was asked to choose between two possible approaches to a specific function, attitude or, concept. Questions found in Part II of the questionnaire will be discussed in connection with their corresponding subjects in Part I. For example, questions 77 and 78 will be discussed in connection with section I of part I under the subject of Administration and Organization.

In discussing each of the sections of the questionnaire, first, there will be a preliminary statement concerning the nature of the work involved. Secondly, an analysis of the results with appropriate tables or exhibits will be presented. Third, a brief summary and conclusion will follow.

Section I--Concerning Administrative and Organizational Expectations of the Pastor Concerning Organization and Administration

The Christian church has always had some form of organization since its inception. This has necessitated religious administration. 
The local church pastor may engage in administration and organization in practically every level of his work. It may be educational-involving the church school and Sabbath school; it may be financial-involving the church budget; or, it may be managerial--directing an office in the church.

How the pastor conceives the function of the church in the world will determine his administrative approach. If he thinks of the church only as a center for preaching, he may resent the demands made upon him for counseling or directing the work flow of others. He may prefer to serve as the chief minister and evangelist and expect others to serve as helpers to his ministry. On the other hand if he sees the ministry as ultimately belonging to the church, he will function in a different manner. He will likely be less autocratic and more democratic in his leadership style. He will see himself as one minister among many other ministers his only advantage being his special skills and training. He will welcome every skill and talent in other members of the congregation as a potential benefit to the total ministry of the church.

What is church administration? It is defined as:

The necessary activities of church leaders involved in leading the church toward fulfillment of its total ministry. These activities include the organizing, planning, and promoting the church's program through enlistment of all members to participate in the work necessary for the achievement of the church's mission. 1

While the Christian church has always required administrators, changes in the current century have made the skill almost

$1_{\text {Franklin M. Segler, A Theology of Church and Ministry }}$ (Nashville, Tenn.: Broadman Press,, 1960), p. 207. 
mandatory for the local pastor. Since 1900 the church has made greater demands upon the pastor. According to Leach, "The minister's tasks have doubled and tripled. Church offices have become common practice in the parish. Collections have given way to church finance. Pulpit announcements have been succeeded by good programs of public relations." 1 A new type of minister has emerged in the current century. He seldom lives in the parsonage next door to the church but owns his own home in the suburbs. He is likely to leave his home each morning and commute to his office as do many others of the business world. He will care for administrative matters during the morning hours, visit hospital patients or homes in the afternoon, and return to his home in the evening. The church facilities are in almost daily use. As administrator, he serves as an imparter of information, director. of his part-time office secretary, and general overseer of the total program of the church.

Whether the local pastor accepts the administrative role as a part of his portfolio or not, he functions as an administrator. It is expected of him today. He is the head of the local church. He may do well or poorly, but he is still the administrator of the local church. Vidich and Bensman found in their study of a local congregation that no matter what other skills the pastor has he is expected to be a good organizer. They found that "if the minister

\footnotetext{
$1_{\text {William H. Leach, Handbook of Church Management (Englewood }}$ Cliffs, New Jersey: Prentice-Hall, Inc., 1958), p. 1.
} 
is not a good organizer, he is a poor minister. No allowances are made for lack of administrative ability."1

While the pastor is truly an administrator it is with a difference. He must administer from a different base than his business executive counterpart. He works with a voluntary social system. His constituents are loyal to the organization from motivations that vary widely from person to person. His administrative skill must be greater because it is person centered and relational and is of eternal consequence. He must lead but he is unable to utilize material rewards and punishments for cooperation or non-cooperation. However, he may still use the skills of an administrator.

Unfortunately the average pastor has received little training in church administration during his formal schooling. He is trained in theology, in preaching, and, to some degree, in pastoral counseling. He has had very little training in church management which, according to Blizzard, occupies about 50 percent of his time in the parish. ${ }^{2}$ Furthermore he finds administration, as it is carried out today, difficult to support theologically or biblically. This may tend to place it in a lower priority level than certain other functions such as preaching, teaching, or praying. To engage

${ }^{1}$ Arthur J. Vidich and Joseph Bensman, Small Town in Mass Society, quoted in S. Burkett Milner, An Empirical Examination into the Ministerial Role Expectations of Clergy (Northwestern University: Unpublished Doctoral Thesis, 1970), p. 14.

2Blizzard, "The Minister's Dilemma," The Christian Century (April 25, 1956), p. 509. 
In it may create a feeling of futility or frustration. He may be reactive rather than proactive in his administrative task. He may become confused as to the limits of his task.

What must the pastor do? First, he will need some knowledge of executive methods. He will need to delegate intelligently and discreetly. He will need to work smarter, not harder. Secondly, he will need to make his congregation and conference aware of his work load so that he may be able to negotiate objectively with them for a more successful ministry. Neither congregation nor conference officials will be aware of his work load without some tangible knowledge being made available to them. It is with this purpose in mind that the following analysis is done.

\section{Responses from the Survey}

The discussion of the section on administration and organization will be divided into several parts. They include leadership style, inner-church duties, duties outside the church, the administrative center, and the symbolical nature of his position.

Leadership style. Since administration involves activities that enhance the mission of the church, much of what the pastor does is administrative. Using this definition, such activities as planning the Sabbath worship service or organizing an evangelistic outreach program are administrative. In fact, the pastor uses administrative skills in practically every aspect of his work.

Each pastor approaches his task with a different style, however. Most styles may be grouped under three descriptive terms 
which include autocratic, participative, and laissez-faire. The autocratic style assumes more of an authoritarian approach; the participative style attempts to involve others in the leadership role; and the laissez-faire tends to identify with those who follow. Each may be useful under certain conditions. However, the pastor's personality profile, his insight into human nature, and his theological frame of reference will incline him to one or the other of these as his dominant style:

Which style did the laymen and conference group prefer in this present study? Two items were included in the survey that were designed to measure leadership style preferences. Item 77 asked the respondent to choose between a more participative (A) or a more autocratic (B) style. The respondents as a whole favored the participative style, as can be seen in table 10 . It will be observed, however, that significant differences exist between certain pairs of subgroups. For example, the over-fifty-year-old group tend to favor of the autocratic style ( 38.27 percent) along with those who attend less than every week (40.54 percent). The groups least in favor of the autocratic leadership style were the under-twenty-year-age group (20.70 percent) and the conference group (13.00 percent).

This survey item was an attempt to determine which of the two approaches used by the pastor was most acceptable to the members of the church. In the participative approach the pastor sees the laymen as fellow-ministers. The pastor is a minister among ministers. He and his parishioners stand as equals before 
TABLE 10.--Number and percentage of responses by congregation and ministers concerning the leadership style of the pastor of the Grand Rapids Central SDA church in reply to the statement: What leadership style is most acceptable?

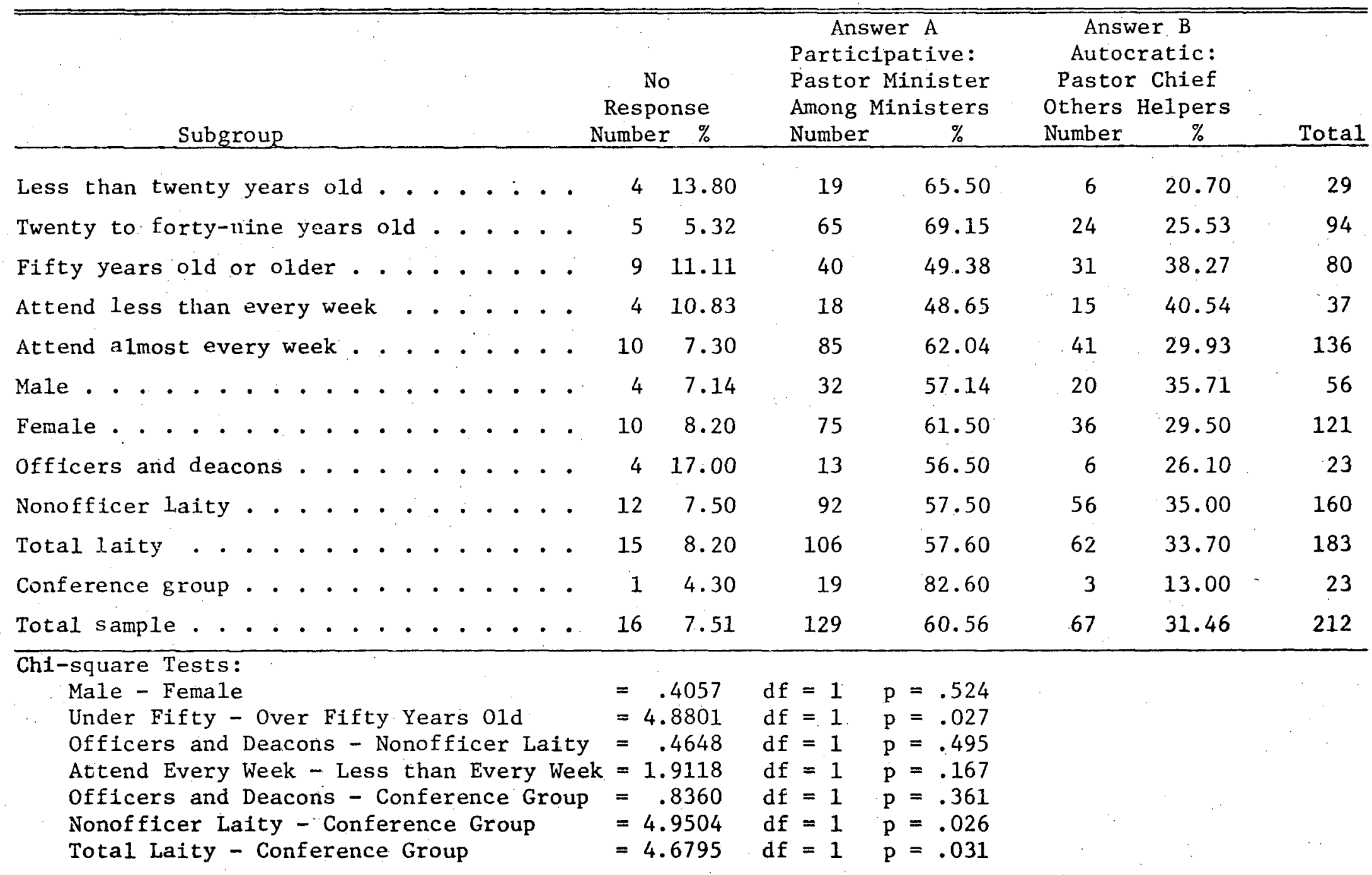


God. The pastor's skills and training only make him the leader. These competencies are used for the good of the total ministry of the church: The ministry belongs to the church not to the minister.

On the other hand the autocratic approach sees the pastor as the chief. The laymen are his helpers in the ministry. The ministry belongs to the pastor. The congregation is seen as having a ministry only as it relates to the pastor and his ministry. Unfortunately many respondents seem to prefer this style. It may have implications for the pastor who tries to involve the church member as a part of the total ministry of the church.

Item 78 of the questionnaire concerns the style of leadership involved in the setting of objectives for the church. See table 11 for number and percentage of responses to this item. In 78-A, the pastor sees himself as setting the goals and the laity joining him in the achievement of those goals. The minister does the planning for the church's ministry. The laymen are involved at the action stage.

The approach described in $78-B$, however, includes the laity in the whole planning process. It even suggests that the congregation has goals and objectives of its own. It also assumes the pastor will have goals of his own. This approach necessitates negotiation between the members of the congregation and the pastor concerning their goals and objectives. Out of this emerges a new set of goals that perhaps both can mutually agree upon as best for all that are involved. Thus an entirely new ministry is created. 
TABLE 11.--Number and percentage of responses by congregation and ministers concerning a successfu1 ministry of the pastor of the Grand Rapids Central SDA church in reply to the statement: How will the pastor be most successful in setting objectives?

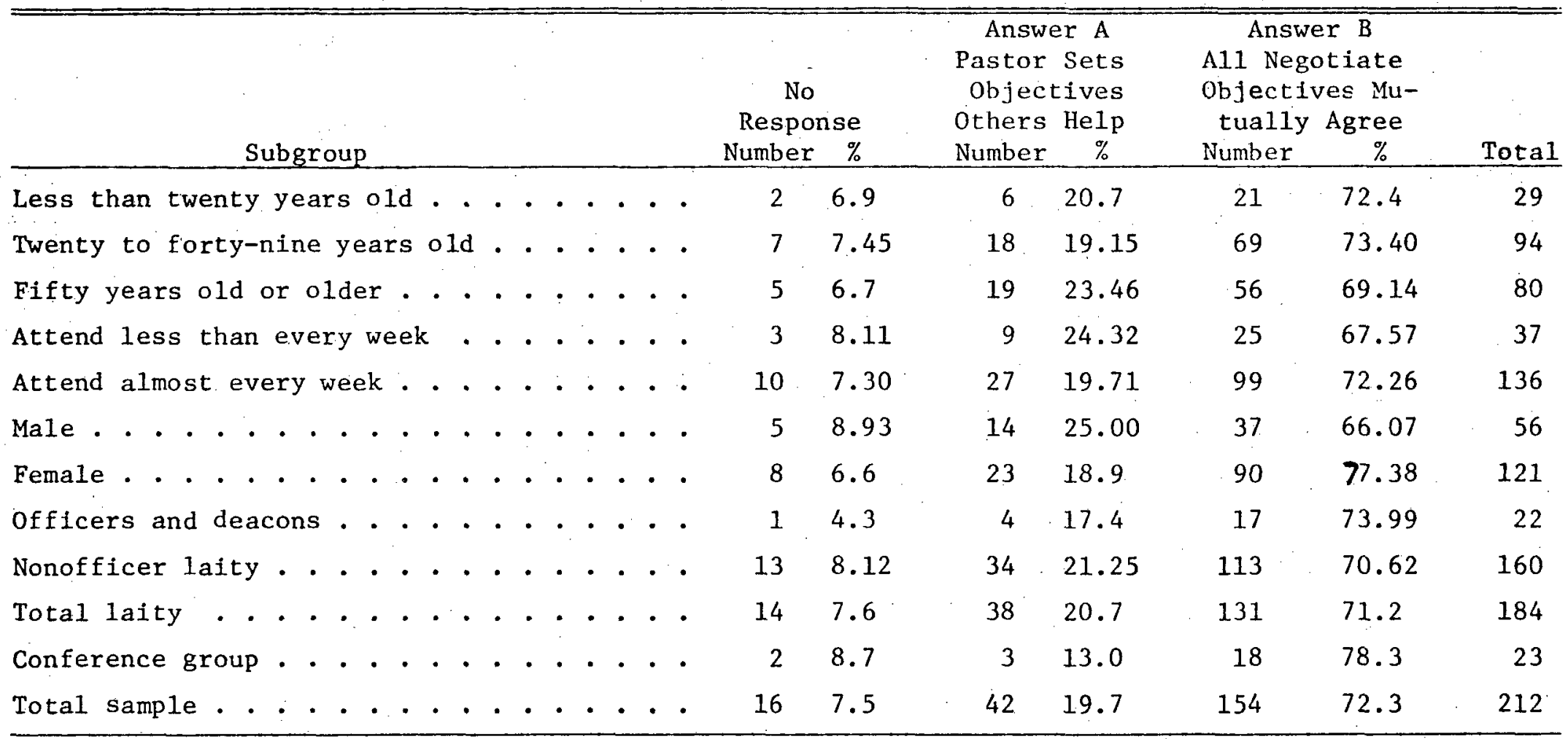

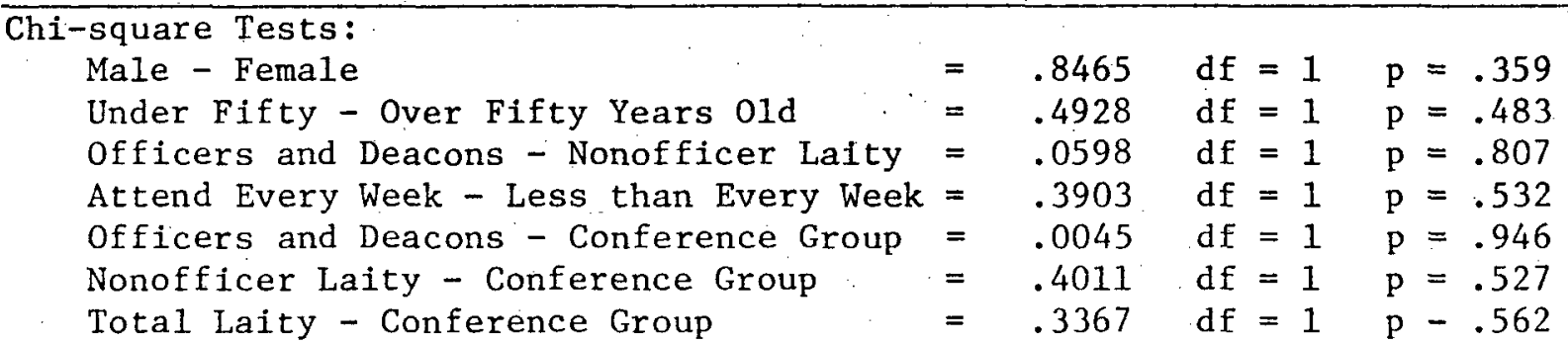


The 78-B answer was overwhelmingly favored by the majority of the respondents. Nevertheless, 20.70 percent of the 1aymen favored the 78-A response which places the goal setting upon the minister's shoulders. Only 13 percent of the conference group were in favor of this leadership style. There was no significant difference between any of the pairs of subgroups in item 78 indicating that a high degree of unity exists on this item.

There is some significance to the above preference for the laymen to be involved in planning. When this response is compared with item 13 of the survey form, which states that the pastor should "map out plans, for the overall church program for out-reach evangelism and care of new members," a total of 177 , or 83.10 percent, of the respondents either felt the pastor absolutely must or preferably should perform this function of chief strategy planner. The implications for conflict on the part of the pastor are obvious. If the leadership style preferred is a negotiating approach to goal setting and planning, he may find himself in trouble with at least some of his parishioners in this church if he does all the planning himself. Perhaps the favorable response to $78-B$ indicates what the church would like to see, but the response to item 13 indicates what has been done in actual practice by most pastors and is, therefore, expected by the congregation. The feeling by many in the congregation may be expressed in the words of one respondent who wrote in the comment, "More suggestions by all members as to the betterment and growth of 
the church would be good." 1 It is good that some are concerned about the betterment of the church and would like to be involved in making plans and setting goals.

In summary, it appears that the Grand Rapids Central SDA pastor's role set generally prefer the participative style of leadership even though some diversity of opinion exists between certain pairs of subgroups. The congregation prefers to negotiate with the pastor the goals for the church but perhaps they feel that he should map out plans concerning evangelistic outreach and care of new members.

Inner-church involvements. It is within the church program itself that the pastor demonstrates his leadership style. It would not be surprising if many in the subgroups surveyed feel that the pastor ought not to be involved in any responsibilities outside the local church. The congregation under study is large enough to keep him and his assistant busy. At least one respondent felt this way and stated, "I feel the pastor should have less outside duties than presently Grand Rapids pastors have. Be present more also in the Grand Rapids church."

A total of eight of the seventeen items in section $I$ of the survey form dealt mainly with inner-church matters. They were items 1 through 5,12,13, and 14 . Item 13 concerning the pastor's role in planning the evangelistic endeavors of the church has beendiscussed above. (A summary of the median responses may be seen in table 12.) 
TABLE 12.--Median responses of the congregation, conference committee, and certain ministers concerning administrative and organizational expectations of the Grand Rapids Central SDA pastor

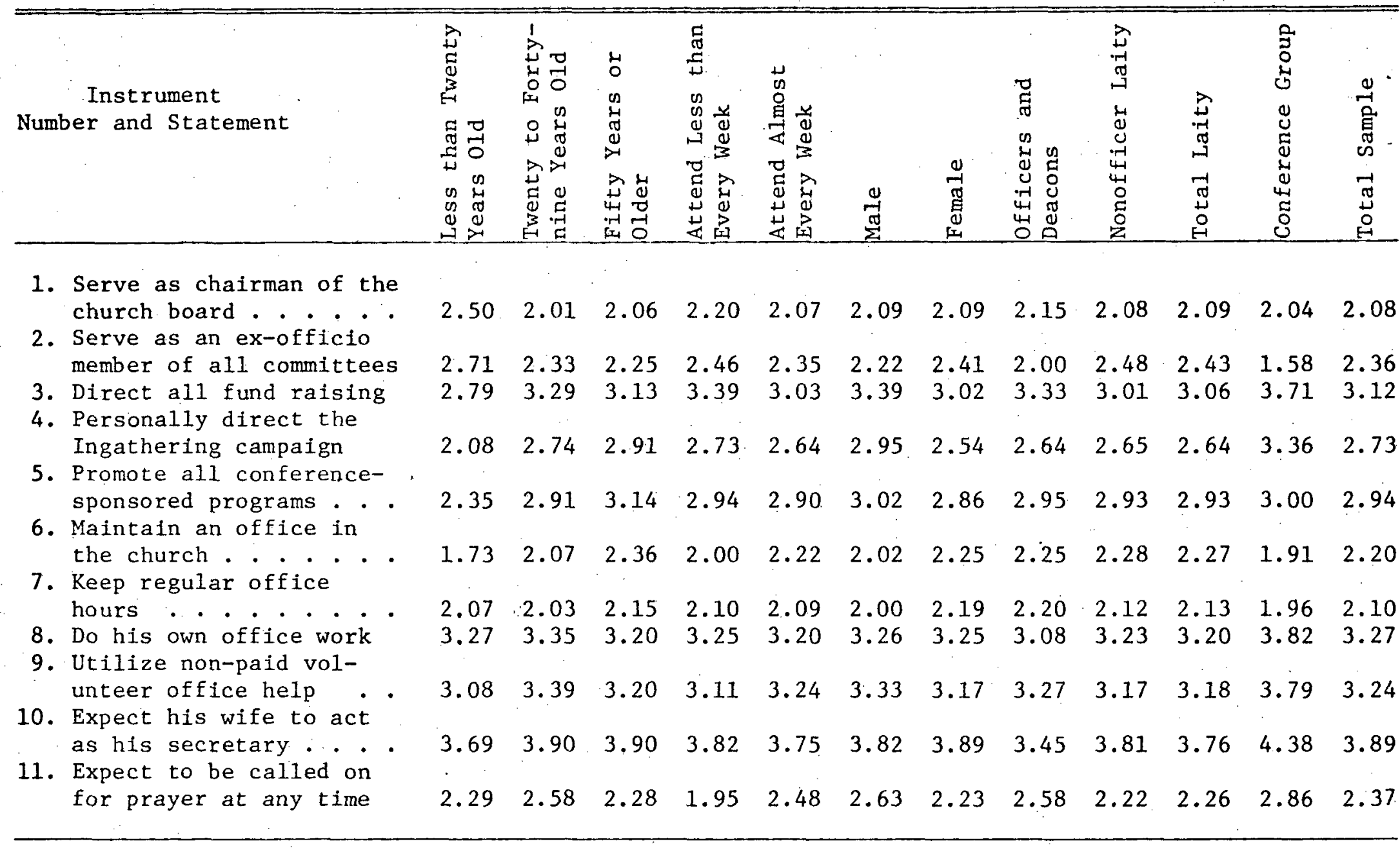


TABLE 12 (Continued)

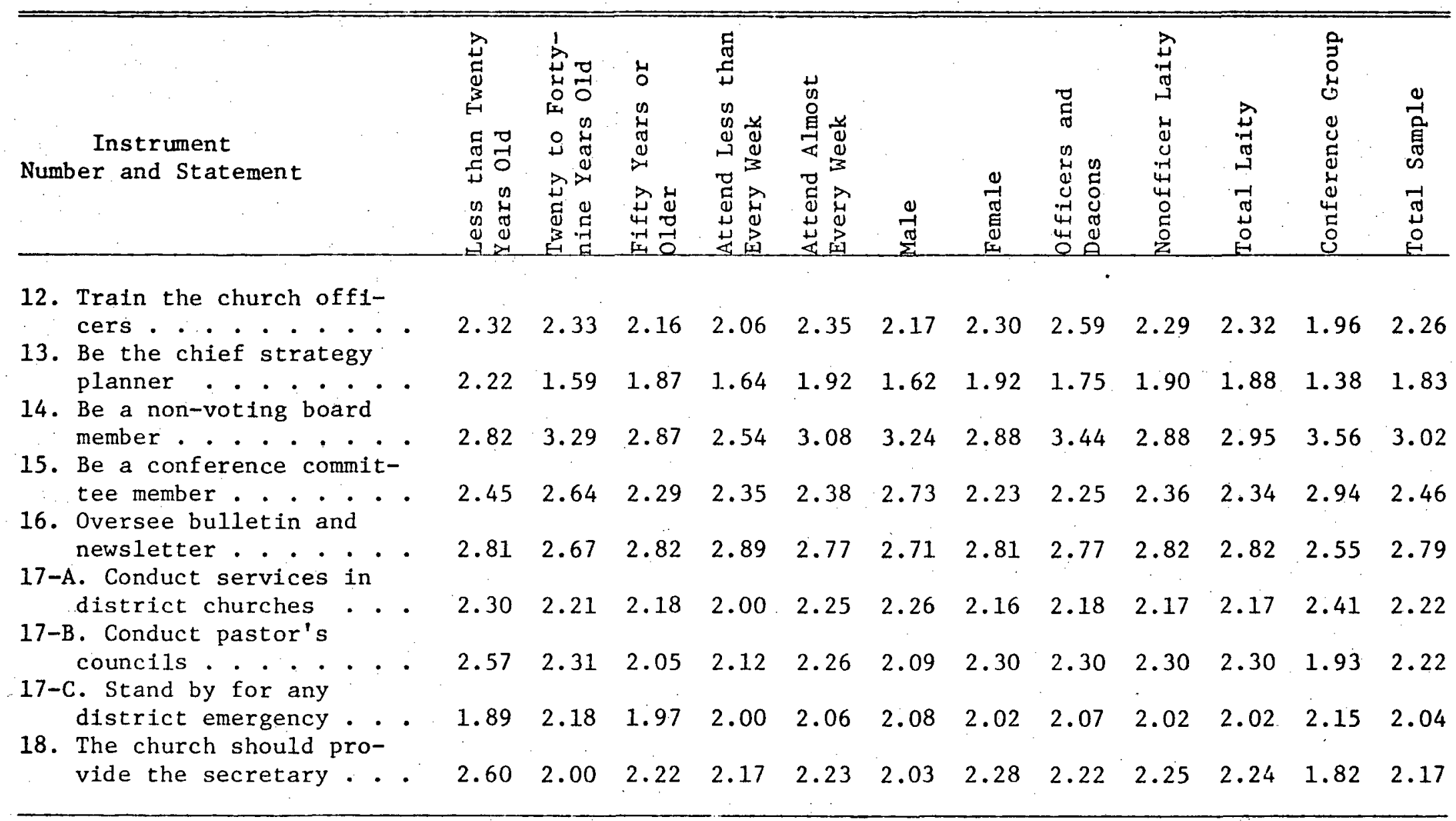

Median figures are based on a range of one to flve as follows: 1 - Absolutely must 2 - Preferably should 3 - May or may not 4 - Preferably should not 5 - Absolutely should not 
Item 1 states that the' pastor should "serve as chairman of the church board.". The total sample scored 2.08 at "preferably should," on the one-to-five median scale. Only twelve of the total sample, all laymen, felt the pastor should not serve as chairman of the board. All but one of the twelve were in the nonofficer laymen group. The great majority of the board members favored the pastor acting as chairman of the board.

Traditionally, SDA pastors serve as chairmen of their church boards. Perhaps there is good reason for this, and yet it is here where many pastors become deeply involved in administrative tasks. One wonders whether the following would apply to this matter:

I have been instructed in regard to the importance of our ministers keeping free from responsibilities that should be largely borne by businessmen. . . . Those who are employed to write and speak the word should attend fewer committee meetings. ${ }^{1}$

There was less agreement among the members of the pastor's role set concerning item 2 , which states that the pastor should serve as an ex-officio member of all other boards and committees set up by the church. The conference group is almost unanimóusly in favor of this, 1.58 on the five-point scale between "absolutely must" and "preferably should." The congregation level is nearly one full digit more on the scale, 2.43 , between "preferably should" and "may or may not." This may indicate that the conference group feels that the minister must have access to all that goes on within his church in order to keep control. The laity, on the other hand,

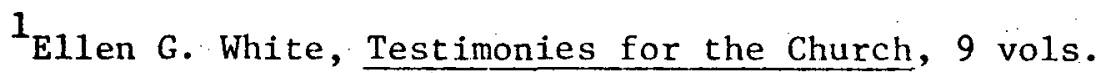
(Mountain View: Pacific Press Publishing Association, 1948), 7:246, 247. 
may feel they are capable of more of the committee work than they are at present handling.

Item 3 of the survey concerns the pastor having charge of al1 fund-raising programs of the church, such as combined budget, building fund, and so forth. There was general agreement that the pastor of this church should not act in this capacity, 3.12 on the scale. However, the conference group was considerably stronger in their opposition, 3.71, than were the laymen, 3.06. The laymen are about equally divided on this issue leaving it perhaps to the situation and to the pastor's wishes in the matter. The ministers may be familiar with the statement: "Our greatest burden should not be the raising of money, but the salvation of souls."1

Related to item 3 was item 4 which stated that the pastor should "personally direct the annual Ingathering program." The analysis of the responses to this question reveals that a strong agreement exists among the laity that the pastor should have direct charge of the annual Ingathering program. An equally strong agreement exists among the conference group that the pastor should not have direct charge of the Ingathering program. On no other item In this study was the congregation and the conference so diametrically opposed. Table 13 gives the full response of all subgroups for this item.

The Ingathering program is an annual fund-raising drive for the denomination's spiritual, educational, medical, and welfare work around the world. A large percentage of the funds goes over- 
TABLE 13.--Number and percentage of responses by congregation, conference committee, and ministers in reply to the statement: The Grand Rapids Central SDA pastor should personally direct the Ingathering program

\begin{tabular}{|c|c|c|c|c|c|c|c|c|c|c|c|c|c|c|}
\hline \multirow{2}{*}{\multicolumn{2}{|c|}{$\begin{array}{l}\text { Sub- } \\
\text { group }\end{array}$}} & \multicolumn{2}{|c|}{$\begin{array}{c}\text { No } \\
\text { Response }\end{array}$} & \multicolumn{2}{|c|}{$\begin{array}{l}\text { Absolutely } \\
\text { Should }\end{array}$} & \multicolumn{2}{|c|}{$\begin{array}{l}\text { Preferably } \\
\text { Should }\end{array}$} & \multicolumn{2}{|c|}{$\begin{array}{l}\text { May or May } \\
\text { Not }\end{array}$} & \multicolumn{2}{|c|}{$\begin{array}{l}\text { Preferably } \\
\text { Should Not }\end{array}$} & \multicolumn{2}{|c|}{$\begin{array}{l}\text { Absolutely } \\
\text { Should Not. }\end{array}$} & \multirow[b]{2}{*}{ Number } \\
\hline & & Number & $\%$ & Number & $\%$ & Number & $\%$ & Number & r $\%$ & Number & $\%$ & Number & $\%$ & \\
\hline ess than twenty & & & & & & & & & & & & & & \\
\hline $\begin{array}{l}\text { years old . } \\
\text { Twenty to forty- }\end{array}$ & • & & & 7 & 24.10 & 13 & 44.80 & 9 & 31.00 & & & & & 29 \\
\hline $\begin{array}{l}\text { nine years old } \\
\text { Fifty years old }\end{array}$ & - & & & 19 & 20.21 & 30 & 31.91 & 34 & 36.17 & 8 & 8.51 & 3 & 3.19 & 94 \\
\hline $\begin{array}{l}\text { or older } \\
\text { Attend less than }\end{array}$ & • & 4 & 4.94 & 7 & 8.64 & 19 & 23.46 & 36 & 44.44 & 14 & 17.28 & 1 & 1.23 & 81 \\
\hline $\begin{array}{l}\text { every waek } \\
\text { Attend almost }\end{array}$ & • & 2 & 5.41 & 6 & 16.22 & 11 & 29.73 & 9 & 24.32 & & & & & 37 \\
\hline every week . . & • & 2 & 1.46 & 20 & 14.60 & 39 & 28.47 & 59 & 43.07 & 13 & 9.49 & 7 & 2.92 & 137 \\
\hline Male . . . . & - & & & 6 & 10.71 & 15 & 26.79 & 25 & 44.64 & 10 & 17.86 & & & 56 \\
\hline $\begin{array}{l}\text { Female } \\
\text { Officers and }\end{array}$ & • & 4 & 3.33 & 20 & 16.40 & 37 & 30.30 & 45 & 36.90 & 12 & 9.8 & 4 & 3.30 & 122 \\
\hline deacons . . . & • & 1 & 4.30 & 2 & 8.70 & 7 & 30.40 & 11 & 47.80 & 1 & 4.30 & 1 & 4.30 & 23 \\
\hline Nonofficer laity & $\theta^{\circ}$ & 4 & 2.50 & 23 & 14.37 & 46 & 28.75 & 62 & 38.75 & 21 & 13.12 & 4 & 2.50 & 160 \\
\hline Total laity . . & - & 5 & 2.70 & 26 & 14.10 & 53 & 28.80 & 73 & 39.70 & 22 & 12.00 & 5 & 2.70 & 184 \\
\hline Conference group & • & & & 2 & 8.70 & & & 11 & 47.80 & 9. & 39.10 & 1 & 4.30 & 23 \\
\hline Total sample . & • & 5 & 2.30 & 28 & 13.10 & 56 & 26.30 & 87 & 40.80 & 31 & 14.60 & 6 & 2.80 & 213 \\
\hline
\end{tabular}

\begin{tabular}{|c|c|c|c|c|}
\hline quare Tests: & & & & \\
\hline Male - Female & 2.8486 & $\mathrm{df}=4$ & $\mathrm{p}$ & .58 \\
\hline Under Fifty - Over Fifty Years Old & 6.6700 & $\mathrm{df}=4$ & $\mathrm{p}$ & .154 \\
\hline Officers and Deacons - Nonofficer Laity & $=$ & $\mathrm{df}=4$ & $\mathrm{p}$ & $=.922$ \\
\hline Attend Every Week - Less than Every Week & 6.3749 & $\mathrm{df}=4$ & $\mathrm{p}$ & $=.173$ \\
\hline Officers and Deacons - Conference Group & $=10.0429$ & $\mathrm{df}=4$ & $\mathrm{p}$ & $=: 040$ \\
\hline Nonofficer Laity - Conference Group & $=12.4773$ & $\mathrm{df}=4$ & $\mathrm{p}$ & $=.014$ \\
\hline Total Laity - Conference Gr & $=13.9528$ & $\mathrm{df}=4$ & $\mathrm{p}$ & $=.007$ \\
\hline
\end{tabular}


seas and a certain percentage, scaled according to the amount raised, returns to the local church for its welfare work. Most of the funds are obtained from contacts with local businessmen, friends, and door-to-door canvassing. A goal based on the number of members and potential territory is assigned by the conference committee for each local church.

The pastor, as an employee of the conference, represents the conference to the local church. While local church leaders receive much of the promotional material concerning Ingathering, the pastor also receives the material and is at least expected to see that this program is carried out. An administrative crisis develops when the layman assigned to the task refuses or otherwise fails to carry it out. The possibilities for conflict for the pastor are very real in this aspect of his work.

As table 13 reveals, the percentages of the laity in favor of the pastor personally directing the Ingathering were about the same as the percentages of the conference group opposing his performing this task. On this point, the conference group was significantly opposed to every subgroup within the congregation with which they were compared. Evidently there is a great degree of misunderstanding existing between the conference leaders and the local congregation as to just what the role of the pastor is in connection with the Ingathering program. This provides an important area for negotiation and clarification. The pastor and writer is inclined to share the convictions of the laity on this matter. 
Another inner-church activity that involves the pastor as a representative of the conference is found in item 5 of the survey form. It states that the pastor should promote in his church all conference-sponsored periodical subscription and financial campaigns. It is of interest that the responses of the conference group were in the middle of the five-point scale, 3.00. The laity scored 2.93 on the scale. From this it appears that the pastor may make his own choice in the matter as to how he relates to these promotional programs. Judging from past experience and observing other pastors, the writer would conclude that his loyalty will lead him to comply with practically any promotional program the conference suggests. This desire for the pastor's loyalty to the conference may also be found among the laity as seen by one personal comment: "A well-rounded pastor should pay equal attention to all programs laid down by the church at the conference level, not only his pet programs." 1

Item 12, stating that the pastor should train church officers, received strong support. This would normally be expected from the pastor. However, training others is a highly specialized skill which requires a breadth of experience and training that many pastors have not had. Also many of the officers are themselves mature, experienced church leaders in the local church. The fact may be that the pastor will learn from his officers as much as he teaches them. In the focal church of this

${ }^{1}$ See Exhibit B, number 154 . 
study the senior pastor is usually mature both in age and experience and should be able to meet this requirement.

Should the pastor be only a non-voting member of the boards and committees on which he serves in the focal church of this study? Since the median response for the total sample was 3.02 on the one-to-five scale, it appears to be a question unanswered in the minds of the respondents. A closer look shows that the median responses indicate the middle-age group (twenty to forty-nine), the men of the congregation, and the conference group all feel the pastor should not be a voting member. All the other groups feel. he should.

These few items gives some insight into the feelings of the focal church and the conference group concerning inner-church activities of the pastor. That activities outside the focal church does the pastor have? How favorable or unfavorable is his role set to these activities? This will be discussed in the next portion of this study.

Involvements outside the local church. In general most local pastors do not have many demands made upon them for activities outside their local community or church. However, the external duties of a local pastor increases considerably if he serves as district superintendent, as a member of the conference executive committee, and of a conference-operated school board. All these external responsibilities are a part of the position of the pastorate under discussion. The largest share of two days each month is spent attending the committee and board meetings. The 
district superintendent work involves more emergency calls than structured appointments, although a pastor's council which may take a good portion of one day is called every two or three months. A few special meetings may occur throughout the year because of the position as district superintendent and conference committee member. While these require the pastor's time they are usually uplifting and spiritually stimulating so that he does not mind the time involved.

The response to item 15, which concerns the pastor expecting to serve as a member of the Michigan conference executive committee, was favorable for all the groups surveyed. The conference group, however, was significantly less strong in its response toward his serving in that capacity, at 2.94 on the median scale, as compared to the laity 2.34 .

Since it is an elected office, the conference group may be more accurate in saying that he may or may not be elected.

Items $17-\mathrm{A}, \mathrm{B}$, and $\mathrm{C}$ asked the respondent to express his expectations in regard to the pastor's external church involvement as it concerns his position as district superintendent. From the responses the general feeling is that the pastor ought to fulfill the duties described in chapter IV, page 87, above. The median range for the total sample for both $17-\mathrm{A}$ and $17-\mathrm{B}$ was 2.22 , a little under the "preferably should" response. For 17-C the total sample response was a little stronger, at 2.04 , the pastor is expected to be available for emergency services throughout the district. 
It is the impression of the writer that a great deal of ambiguity exists in the minds of many laymen as to just what the work of district superintendent actually requires. This may be because it is not clear in the minds of either the pastors or conference officials. While the district superintendent is a recognized position in the Michigan Conference of Seventh-day Adventists, it has not been adopted by any other local conference. It is to be observed that the pastor of the focal church will need to be well organized. He will also need a center from which to administer his pastorate. From what point does he administer the parish? How much help can he expect from the congregation? To these and other questions this study will now address itself.

The pastor's administrative center. Many pastors prefer to work out of an office in their home. Others prefer an office in the church itself. There are arguments in favor and against both these locations. Much depends upon the local situation, the pastor himself, and his family needs. If he has very small children it may be more difficult to isolaté himself for study and prayer within the home itself. The "public" environment of the church may make privacy equally difficult. The writer prefers the church location and has maintained a church office in most of his pastorates, including the one in this study.

Closely related to a suitable office location is obtaining suitable office help. As with the church involved in this study, most local SDA congregations make no provision in their budgets 
for paid secretarial help for either the pastor or the church. Most churches rely on volunteers who donate their talents and time. This may be good or bad depending much upon the individuals involved and their commitment and devotion to the church.

The instrument used in this study included seven questions concerning the above matters. Items $6,7,8,9,10,16$, and 18 deal with the administrative center and the arrangements for office help.

Items 6 and 7 concerned maintaining an office in the church and keeping regular office hours. The responses for the total sample were favorable at 2.20 on the scale for item 6 and at 2.10 for item 7. The conference group was even more intensely favorable at 1.91 for item 6 and 1.96 for item 7 . While there would probably be no objection to an office in the home as the administrative center, it appears most would prefer the pastor of the focal church to use the office furnished and available for that purpose in the church. Maintaining regular office hours may be more difficult for the pastor because of the frequent emergency calls he receives. An office secretary would help him to maintain a more regular schedule as far as his office is concerned. Many SDA congregations today do have office help either paid or volunteer. This secretary receives phone calls, maintains order, assists in the keeping of records, and types letters and sermon materials.

Items $8,9,10$, and 18 were designed to elicit the expectations of the pastor's role set concerning the arrangement of 
secretarial assistance in his ministry. Should he do all his own letter writing, filing, and record keeping as stated in item 8 ?

The answer is, no, according to the responses, 3.27 for the total sample on the median scale. The conference group was significantly more opposed, 3.82 on the median scale.

Should the pastor rely wholly on paid volunteer help to do his office work? Here again the answer for the total sample is, no, at 3.24 on the scale. The conference group was still intensely opposed, 3.79 on the scale for item 9.

Then perhaps the pastor's wife should act as his secretary, as stated in item 10 of the survey form. This was even more strongly opposed by all. the subgroups with the conference group at 4.38 on the median scale and the total laity at 3.76 . The intensity of all the subgroups on this is significant. Although the pastor's wife and her role is dealt with in a later section, one comment by a respondent is pertinent here. "After all, only the pastor was hired, not his wife." 1 This, perhaps, typifies much of the feeling on the part of those responding as they did to the matter of the pastor's wife acting as his secretary.

The final solution to the pastor's secretarial help emerges from the responses to item 18 of the survey form. It states that the pastor should expect the church to provide a secretary, either paid or volunteer. A high degree of unanimity among the subgroups that the church should do so resulted from the survey. The laymen

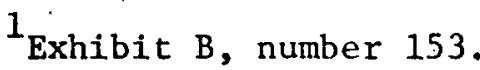


at 2.24 were slightly less enthusiastic than the conference group at 1.82. From this it appears that while there is considerable agreement as to the solution there is much ambiguity as to how to implement what is desired. While excellent volunteer help carries much of the load at present, the amount of work left undone because of the absence of a regular secretary for the pastor and church is probably very great.

One further question dealt with the degree of involvement of the pastor in producing the church bulletin and monthly newsletter. One respondent very emphatically stated, "The minister should not oversee the newsletter, or the bulletin if he can have it [his material] ready by Thursday evening, so the bulletin editor can type it before sundown." 1 A very weak "preferably should" at 2.79 reflects that the total sample would like this to be left to the discretion of the pastor, but with some limitations.

The administrative center out of which the pastor functions has now received attention. In summary it is to be noted that the focal pastor's role set prefers that he function from an office in the church. They would like him to keep regular office hours in order that he may be reached. Finally, they agree that the church should provide some office help for the pastor, either paid or volunteer, to make his work more effective.

The pastor and public prayer. How symbolic do the respondents see the pastor in his position? Item 11 stated that

$1_{\text {Ibid., number } 152 .}$ 
the pastor should expect to be called upon to offer prayer when at gatherings where prayer is needed. In other words because he is the pastor must he always expect to be called upon to pray because of his position? There were significantly different opinions on this item among three pairs of subgroups--the under-fifty/overfifty groups, those who attend regularly/those who attend irregularly, and the conference/tota1-1aity subgroups. A1though a11 groups agreed that the pastor should expect to be called upon to pray, those who attend less than every week were the most emphatic, 1.95 on the scale, while regular attenders responded at 2.48 on the scale being much less emphatic.

Those who are irregular attendants are likely to be less personally acquainted with the pastor than those who are regular attendants. Therefore, they may identify the pastor more as a "role" than as a person.

The conference group was much less in favor of the pastor expecting to be called upon to pray in public, 2.86 on the scale. The ministers would probably like to see themselves on a level with others.

Summary

This analysis has provided certain insights concerning the administrative and organizational functions of the local pastor. In summary the following stand out:

1. An open style of leadership that involves others in the ministry planning and attaining of goals is preferred. 
2. The church and conference group prefer to have the pastor serve on boards and committees on the conference level. They do not oppose his work as district superintendent. At least one person however preferred that the pastor cut back on his outside responsibilities.

3. The church, with strong support from the conference group, is willing to help the pastor with secretarial assistance. Some negotiation may be needed in this matter.

4. The cnurch members are inclined to see the pastoral position as more symbolical than the ministers and the conference group. Both ministers and laymen may need to adjust their concepts of the role somewhat. The laymen may need to see the minister more as a person apart from his position and the symbols of religion that it has. The ministers may need to recognize that when they assume the position of pastor they assume all the overtones that position implies to those around them.

\section{Analysis of Section VIII--Concerning Time Expectations of the Focal Pastor}

Time may be one's master or servant. While every person has an equal amount of time to work, eat, and rest, yet much depends on how a person uses time as to whether it is a master or servant.

Time may be measured, wasted, marked, or lost, but never retrieved. It is one of the most precious gifts God has given to man. In fact one writer declares, "Our time belongs to God."1

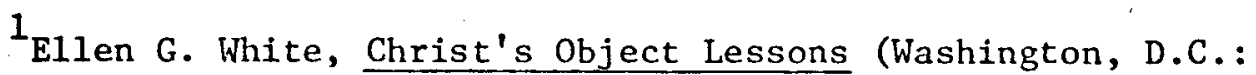
Review and Herald Publishing Association, 1941), p. 342. 
The Bible indicates that time may be redeemed or put to a good use (Eph 5:16). Also God knows no haste nor delay, for "one day is with the Lord as a thousand years and a thousand years as one day" (2 Pe 3:8).

Many moderns live by the clock and this especially characterizes the Christian pastor. His many appointments require him to be aware of the passing of time. The challenge for the pastor is to know how best to use the 1,440 minutes per day and the 168 hours per week allotted to him.

There are many motivations for the SDA pastor to manage well his time. Two stand out. First is the fact that his time "belongs to God." "Every moment is His, and we are under the most solemn obligation to improve it to His glory. Of no talent He has given will He require a more strict account than of our time."1 The pastor must especially consider this counsel as for him. Secondly, a sense of urgency characterizes the SDA religious movement. The unfinished task of the giving the gospel to the world provides church leaders and laity with strong incentives to give themselves unsparingly to this task.

What ratio of time do SDA pastors spend in their work life? While this may vary from pastor to pastor and position to position, the writer found that during a twenty-five-day period he spent an average of 10.5 hours per day in his work. ${ }^{2}$ This totals 73.5 hours for a seven-day week.

$$
1_{\text {Ibid., p. 342. }}{ }^{2} \text { See chapter IV, p. } 90 .
$$


It seems to the writer that few SDA pastors concern themselves about the number of hours they spend in their work each day or week. Their dedication and devotion to their work and the magnitude of their task causes most of them to wonder where the time goes so rapidly. Furthermore, their chief source of counsel, Ellen G. White, states: "The eight hour system finds no place in the program of the minister of God. He must hold himself in readiness for service at any hour."1

Citing the Saviour as an example of how to use the evenings the same writer says, "All day He ministered to those who came to Him; in the evening He gave attention to such as through the day must toil to earn a pittance for the support of their families." 2 Ellen White, however, balances the above statement by saying, "There are hours in the day that call for severe taxation, for which the minister receives no extra salary, and if he chooses to chop wood several hours a day, or work in his garden, it is as much his privilege to do this as to preach." ${ }^{3}$

To help the pastor to determine whether his congregation was aware of how much time he spent at his work and to learn how much time they expect him to spend in his work, one statement was included in the survey form regarding time. Item 70 requested the respondent to "circle the number of hours you expect the pastor of the Grand Rapids Central SDA church to put in each week in all facets of his ministry." The respondent was given a choice of

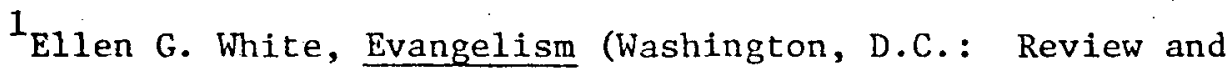
Herald Publishing Association, 1946), p. 652.

${ }^{2}$ Ibid. $3_{\text {Ibid., p. } 660 .}$ 
nine different categories including 30-35, 35-40, 40-45, 45-50, $50-55,55-60,60-65,65-70$, and $70-75$ hours. A second part of the statement then requested the respondent to "underline the number of hours you think he actually puts in per week."

The responses to each part of this question varied considerably. For identification purposes the first part of the question, concerning the amount of time the respondent expects the pastor to spend at his work, will be referred to as part A. The second part, concerning the amount of time the respondent feels the pastor actually spends at his work per week, will be referred to as part B. Tables 14 and 15 give a summary of the numbers of those who responded to certain hour categories.

While there was a wide range of opinion in response to question 70 , part A, concerning the hours per week expected of the pastor, the average was at 52 hours per week. This will be more clearly shown by the median responses as depicted in table 16 .

A different picture emerges, however, from the responses to question 70 , part $B$, concerning the number of hours per week the respondent feels the pastor actually spends at his work. The majority averaged at 65.9 hours per week. As may be easily observed this is 13.9 hours more than the average of 52 the respondents expect the pastor to spend at his work per week.

It is of further interest to note how the various subgroups responded to these questions concerning time expectations of the pastor. Tables 16 and 17 summarize the median responses for 70 , 
TABLE 14.--Responses concerning the number of hours per week the pastor of the Grand Rapids Central SDA Church is expected to spend at his work

\begin{tabular}{lcc}
\hline $\begin{array}{c}\text { Hours } \\
\text { Per Week }\end{array}$ & $\begin{array}{c}\text { Number of } \\
\text { Responses }\end{array}$ & $\begin{array}{r}\text { Percent of } \\
\text { Responses }\end{array}$ \\
\hline $30-35$ & 8 & 3.8 \\
$35-40$ & 10 & 4.7 \\
$40-45$ & 23 & 10.8 \\
$45-50$ & 62 & 29.1 \\
$50-55$ & 36 & 16.9 \\
$55-60$ & 33 & 14.6 \\
$60-65$ & 14 & 6.6 \\
$65-70$ & 7 & 2.8 \\
$70-75$ & 3 & 1.4 \\
No response & 20 & 9.2 \\
\hline Total & & 100.0 \\
\hline
\end{tabular}

TABLE 15.--Concerning the number of hours per week the respondents anticipate the Grand Rapids Central SDA Church pastor spends at his work

\begin{tabular}{lcc}
\hline $\begin{array}{c}\text { Hours } \\
\text { Per Week }\end{array}$ & $\begin{array}{c}\text { Number of } \\
\text { Responses }\end{array}$ & $\begin{array}{r}\text { Percent of } \\
\text { Responses }\end{array}$ \\
\hline $30-35$ & 4 & 1.9 \\
$35-40$ & 5 & 2.3 \\
$40-45$ & 4 & 1.9 \\
$45-50$ & 8 & 3.8 \\
$50-55$ & 17 & 8.0 \\
$55-60$ & 30 & 14.1 \\
$60-65$ & 31 & 14.6 \\
$65-70$ & 44 & 19.7 \\
$70-75$ & 38 & 17.4 \\
No response & 35 & 16.4 \\
\hline Tota1 & 216 & 100.0 \\
\hline
\end{tabular}


TABLE 16.--Response of subgroups concerning the number of hours they each expect the Grand Rapids Central SDA Church pastor to spend at his work each week

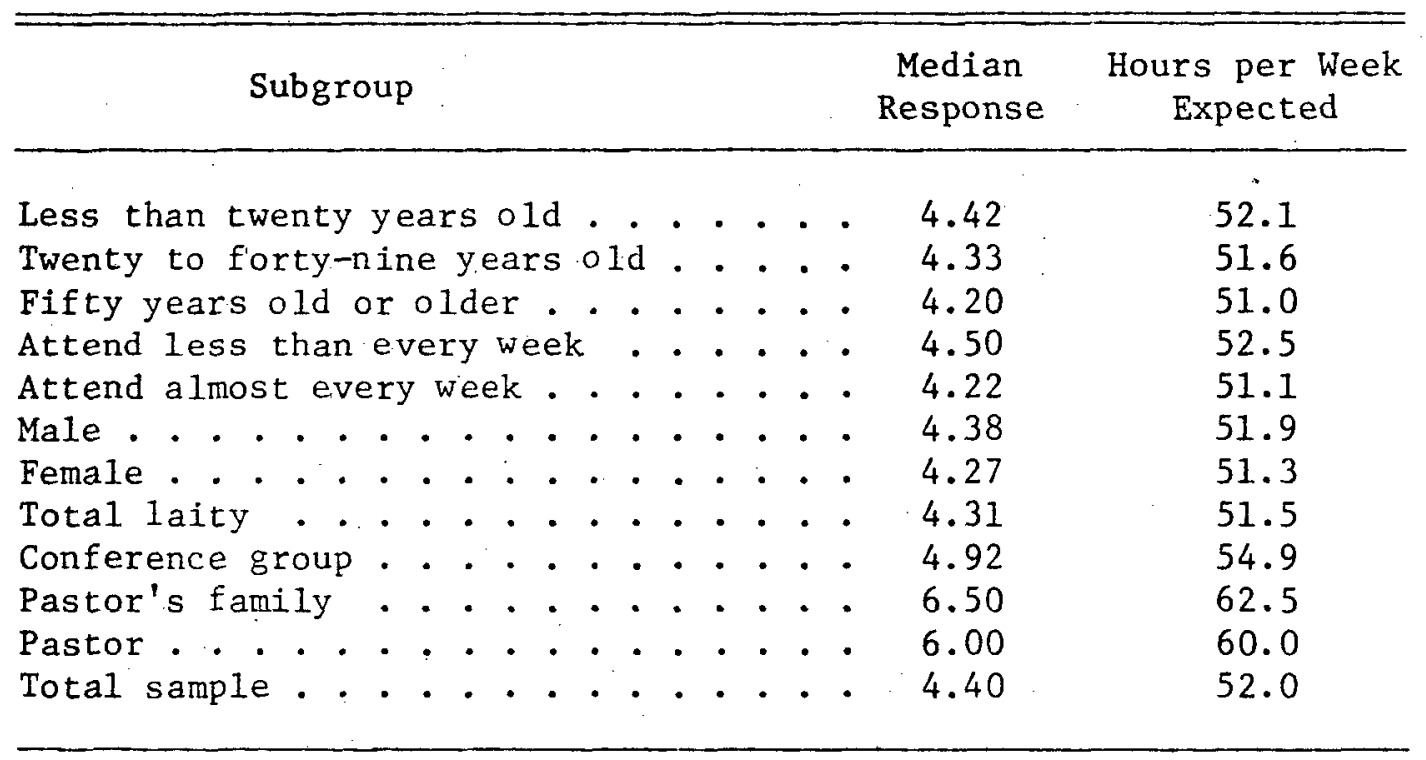

TABLE 17.--Response of subgroups concerning the number of hours they anticipate the Grand Rapids Central SDA Church pastor spends at his work each week

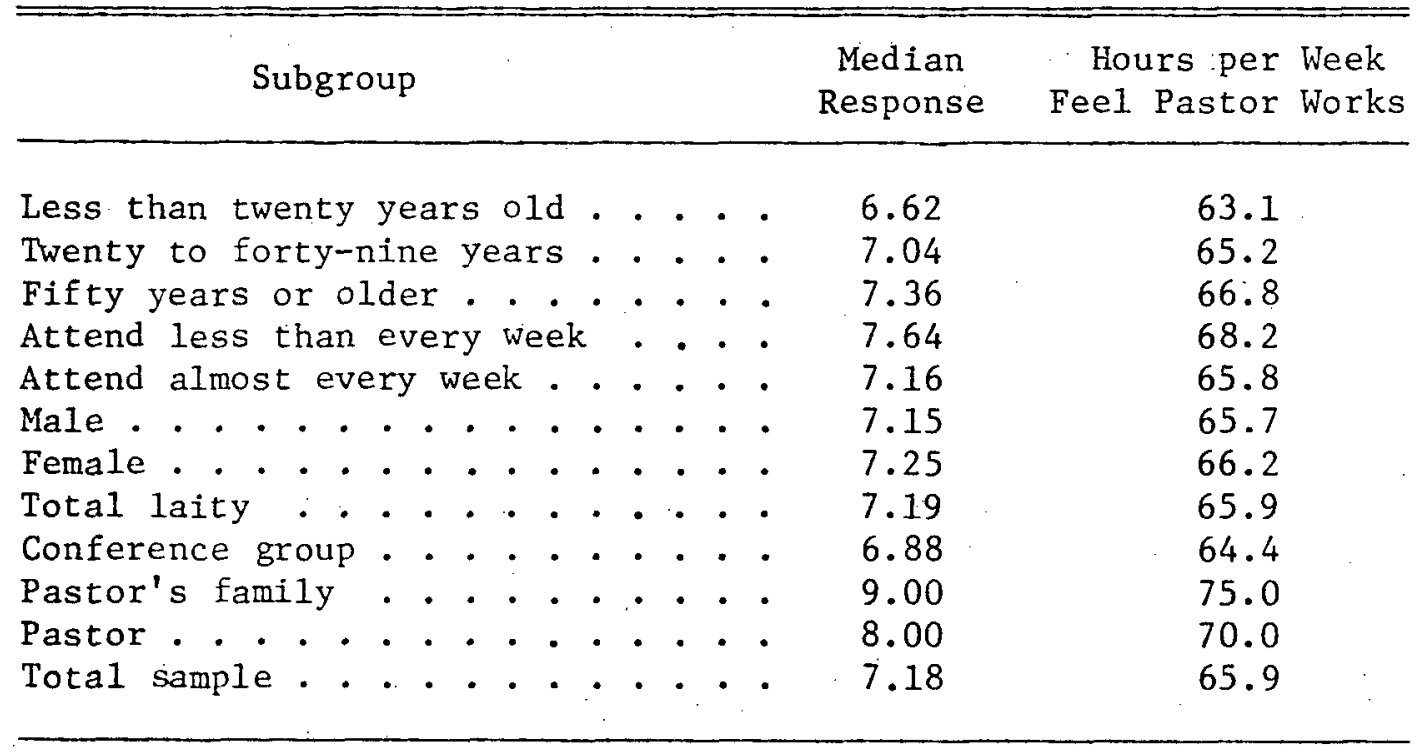


part $A$ and 70 , part $B$. The median response has been converted into actual hours in these tables to give a clearer picture of what is being discussed.

The above table 16 reals some rather significant differences between certain subgroups as to the amount of time expected of the pastor as well as the amount of time the respondents feel he actually spends at his work per week. For instance, by carefully observing table 16 one notices that the pastor's family expects the pastor to be involved 62.5 hours per week, whereas the over-fifty-year-old group only expect 51 hours per week from the pastor. The pastor himself expects 60 hours per week of his time to be involved in his work. The conference group at 54.9 hours expected each week of the pastor was nearest to the pastor and his family at 60 hours. The pastor and his family would obviously approximate the actual number of hours he spends at his work each week.

Table 17 also discloses some definite differences of opinion with the pastor's role set concerning the hours per week the various groups feel the pastor is spending at his work. The pastor's wife and teenage daughter again considered the time the pastor spends at his work to be considerably more than the rest of the role set. The laity group that come nearest to the pastor's family in their expectations were those who attend less than every week, at 68.2 hours per week. However, this is over six hours per week less than the pastor's wife and family who believe the pastor is spending 75 hours per week in his work. 
Who is right concerning the amount of time the focal pastor of this study spends in his work per week? By referring back to the time study made in the previous chapter it appears that the pastor's wife and family are nearer to the actual than any of the role set. As the pastor's wife remarked on her survey form, "I do not imagine, I know!" The time study of the focal pastor's work life during a twenty-five-day period revealed that he spent an average 10.5 hours per day during that period in some form of church work. Multiplying this figure by seven equals 73.5 hours per week. Even the pastor was not aware that he was spending so many hours at his work. It has been a helpful and enlightening revelation. This is especially true since it was discovered that he was involved in his work nearly fourteen hours more per week than his role set expected of him!

A number of personal observations by certain respondents reveal anxiety on the part of some that the pastor may experience an overload as far as his time is concerned. One questioned, "Isn't it true that most pastors actually have to spend more than 75 hours a week in all facets of their ministry? Perhaps as many as 112 hours a week? Especially in a large church like Central."1 Another despaired that the pastor could encompass his work adequately by stating, "It is impossible for one person to perform all the expected duties required. Not enough hours in a month without sleep or rest." 2 "Another complained, "It is hard to answer some questions as has the poor pastor so much time to do all this." 3

${ }^{1}$ See Exhibit B, number 51. $\quad{ }^{2}$ See Exhibit B, number 156. ${ }^{3}$ See Exhibit B, number 101 . 


\section{Summary}

In this chapter the pastor's role set has been disclosed and identified along with specific subgroups of the role set. Some of these were preplanned according to a color code. These include groups, such as the nonofficer laity of the focal church, the officers and deacons of the church, and the conference committee members and certain ministers. Other subgroups emerged from the introductory page of the survey. form. These were formed according to sex, age, and attendance patterns. A total of seven pairs of subgroups provide an ample number for comparative purposes.

Section I of the questionnaire, concerning the administrative and organizational functions, was discussed and the responses analyzed. It was found that the participative style of leadership is generally preferred by the role set. Most of the items received positive and expected responses from the role set. However, there were several disagreements between certain pairs of subgroups over such matters as whether the pastor should personally direct the Ingathering program of the local church, do his own office work, have his wife act as his secretary, and expect to be a chief person to offer public prayer.

Finally an analysis was made of the responses to section VIII of the survey form concerning the time expectations of the focal pastor of this study. The role set generally was considerably lower in the amount of time expected of the pastor per week than the amount he or his family expects of him. The role set was also considerably lower in the amount of time they felt the pastor 
was investing in his work per week than either he or his family. This, of course, indicates that most of the role set are unaware of much that the pastor does. It also indicates that they are not aware of the pastor's use of his time. Were it not for dedication and devotion to the task, the pastor might work considerably fewer hours without anyone knowing it. Perhaps it is good that he does not have to give a strict accounting of his time to his role set since he has a higher responsibility to the One before whom all, one day, must give an account.

There is a wider scope of ministry for the pastor than the local congregation. This is the total community in which he lives. Here people see the pastor as the representative of his church. How should the pastor relate to his local community according to his role set? It is concerning this issue that the beginning of the next chapter is dedicated. This will be followed by an analysis of the remaining sections of the survey. 


\section{CHAPTER VI}

\section{AN ANALYSIS OF THE RESPONSES TO THE SURVEY FORM CONCERNING THE TRADITIONAL EXPECTATIONS OF THE GRAND RAPIDS CENTRAL SDA PASTOR}

In this chapter the six remaining sections of the survey form are discussed, analyzed, and interpretations attempted. These include: section II, Community Relations expectations; section III, Evangelistic and Outreach expectations; section IV, Counseling and Pastoral Visitation expectations; section V, Personal and Family expectations; section VI, Preaching and Worship expectations; and section VII, Teaching and Training expectations. The median responses on the one-to-five scale are provided in table form for each of the sections. These tables and the accompanying analysis provide a basis for measuring attitudes and preferences of the respondents.

\section{Section II--Concerning the Pastor's Community Relations Expectations}

Based on his own observations, the writer is impressed that most Seventh-day Adventist pastors are not much involved in community affairs of cities and towns where they reside. There are exceptions with regard to this, however. Why are SDA pastors so little involved in their local communities? A few reasons may be given. First, a common tension exists between the pastor's desire to be a good citizen of heaven as well as a good citizen of this 
world. Some may point to the Apostle's injunction, "Be ye not unequally yoked together with unbelievers: for what fellowship hath righteousness with unrighteousness? and what communion hath light with darkness?" (2 Cor $6: 14$ ). Undergirding this are the writings of Ellen G. White. Concerning God's people she states,

Their citizenship is in heaven. The Lord calls upon them to stand as a separate and peculiar people. . . His people are to possess the elements of reconciliation. Is their work to make enemies in the political world?--No, no.l

A second reason why SDA pastors are perhaps so little involved in their communities has to do with their theology of mission. The church had dedicated itself to giving a special biblical message to the entire world. The pastor, his conference, and the laity see this as their first priority in terms of service for the world and as their basic reason for existence. They conceive their mission as having consequences for eternity as well as for this present world. (See analysis of item 76, p. 237..)

There are implications for the SDA pastor in these concepts mentioned above concerning his relationships to his local community. The spirit of church unity and a desire for people and groups to come out from behind their separatism places a great challenge upon the modern SDA local pastor. Much depends upon the pastor's self-image and his own personal attitudes toward his place in the community .

The SDA denomination has made great strides in its attempt to develop better public relations in the communities where the

${ }^{1}$ E1len G. White, Fundamentals of Christian Education (Nashville: Southern Publishing Assoc., 1923), p. 479. 
church is found. One SDA writer declares, "A key figure in the church public relations plan is the pastor himself."1 The pastor may not see himself as the ideal SDA churchman but he is expected to be by those in his community. Much, therefore, depends upon the pastor's appearance, manner of dress, attitudes toward people, and his educational, spiritual, and cultural attainments. Also much depends on whether he is outgoing, friendly, and helpful, or whether he is withdrawn, reclusive, and unfriendly. He must have resolved, to his own satisfaction, the problem of separating from the world and being involved with the world.

What can the pastor do to develop better public relations? First, he can be a "minister of introduction." ${ }^{2}$ He may need to be the first to introduce himself to those around his home and city. Secondly, he may become a member of local professional organizations that will place him in contact with new acquaintances and important people in the city. Thirdly, he may participate with a genuine spirit of helpfulness in community affairs. He should do so with a sincere desire to make the community a better place. He will find a much better acceptance if he is involved because of what he can give rather than for what he can possibly receive. Fourthly, the SDA pastor will use caution to avoid political involvements in view of the counsel that "Those in the ministry who desire to stand as politicians ought to have their credentials taken from them." ${ }^{3}$

$1_{\text {Howard K. Weeks, Breakthrough (Washington, D.C.: Review }}$ and Herald Publishing Association, 1962), p. 52.

2 Wayne E. Oates, The Christian Pastor, p. 220.

3 White, Fundamentals of Christian Education, p. 483. 
Finally, the local SDA pastor may discuss his public relations role with his congregation in view of the local needs. This will require information on the part of the entire role set as to what is specifically expected of the pastor in the specific place he serves. It is to an analysis of the responses to the survey form by a specific congregation and conference group concerning the local pastor's role in the local community that the following is directed. The median responses along the one-tofive-point scale of the various subgroups and the total sample surveyed may be examined in table 18 .

The six items concerning the pastor's community relations expectations may be found on the questionnaire, numbers 19-24. Items 19-22 are concerned with the pastor's relationships with prestigious persons and groups in the community; items 23 and 24 are concerned with the pastor's involvement with the news media.

Responses Concerning the Pastor and Prestigious Persons

In almost every community there is a ministerial association of some type. All groups surveyed responded somewhat favorably, at 2.30 on the one-to-five scale, to item 19 concerning the pastor's joining such a group. Further observation reveals that the conference group, members who attend almost every week, and the older age group were least in favor of the pastor being a member of the ministerial association. On the other hand those who attend irregularly and the younger age group were more in favor. 
TABLE 18.--Median responses of the congregation, conference committee, and certain ministers concerning community relations expectations of the Grand Rapids Central SDA pastor Number and Statement

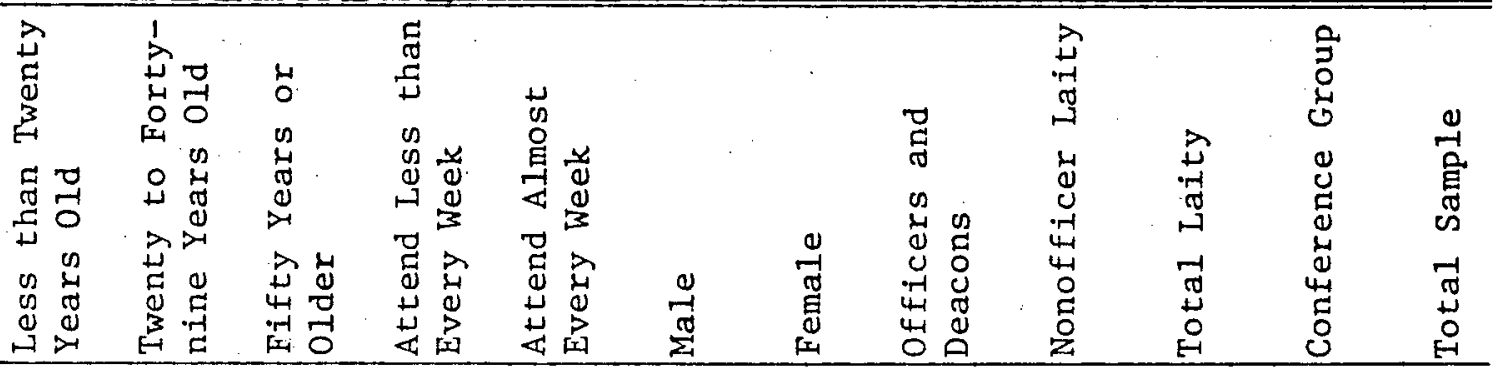

19. Belong to the Grand Rapids Ministerial

Association . . . . . $\quad \begin{array}{llllllllllll}2.22 & 2.20 & 2.34 & 1.97 & 2.36 & 2.34 & 2.22 & 2.06 & 2.30 & 2.27 & 2.54 & 2.30\end{array}$

20. Become acquainted with high public officials.

21. Join one of the

service clubs $\begin{array}{llllllllllllll}0 & 3.03 & 3.14 & 3.22 & 3.02 & 3.20 & 3.12 & 3.18 & 3.09 & 3.21 & 3.19 & 3.07 & 3.17\end{array}$

22. Be active in relieving social injustice, poor, and needy ......

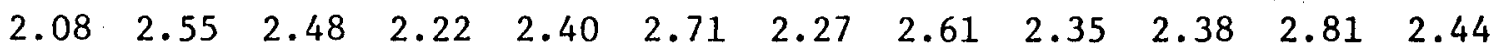

23. Delegate news article writing to another person . . . . . . .

24. Be active in making news media contacts himself

$$
\begin{array}{lllllllllllll}
2.71 & 2.40 & 2.32 & 2.31 & 2.48 & 2.37 & 2.44 & 2.12 & 2.55 & 2.48 & 2.03 & 2.40 \\
2.77 & 3.13 & 3.11 & 2.07 & 3.01 & 3.27 & 2.87 & 3.45 & 2.91 & 2.98 & 3.55 & 3.06
\end{array}
$$

Median figures are based on a range of one to five as follows: 1 - Absolutely must 2 - Preferably should 3-May or may not 4 - Preferably should not 5 - Absolutely should not 
It appears that the more involved with the life of the church the respondent is, the less favorable he is to his pastor's membership in the local ministerial association. The younger generation may be less fearful of "worldly" associations for their pastor than their elders. The pastor, however, may be faced with conflict should he comply with the wishes of some of those in his role set and the counsel which states: "Our ministers should seek to come near to the ministers of other denominations." 1

From the responses to item 20 of the survey form a different picture emerges. It states that the pastor should become acquainted with the public officials, such as the mayor and city manager. The response was "preferably should," at the 2.02 point of the scale for the total sample. It appears that while the role set is not overly in favor of the pastor joining the ministerial association, it is not at all opposed to a one-to-one relationship with public officials.

Furthermore, there was outright opposition by the respondents to the pastor joining one of the local service clubs, such as Kiwanis International. This is the issue of item 21 of the survey form. It is noteworthy that the role set was highly unified on this point. The total sample stabilized at a 3.17 median value. It seems that the respondents prefer their pastor not being involved with groups outside the church itself, at least to the point of joining the group. If the pastor wishes to join one of the

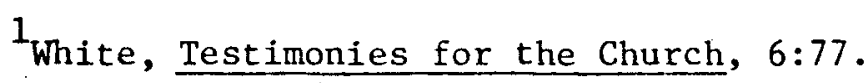


local service clubs he may need to engage in some negotiation with his role set.

There was, on the other hand, a favorable response to the pastor participating in community service organizations to help the victims of injustice and the poor and needy, as stated in item 22 of the survey form. There was general unity among the total sample by a score of 2.44 . The idea was somewhat less supported by the male and conference groups, 2.71 and 2.81 , respective1y.

Certain respondents were especially burdened concerning the ministry to the victims of poverty and injustice. One respondent pleaded, "please don't turn outcasts and drunken folks away with no attempt to aid them; to turn their hearts to God as they ask for help. Where our church is located it should first of all be a mission church for those ones downtown." ${ }^{1}$ The writer is not inclined to agree fully with the respondent quoted above. The church serves a much wider area than just the dorntown area of Grand Rapids. Its mission is to the whole city.

\section{The Pastor and the News Media}

Should the pastor of the focal church of this study write all the news articles himself or should he delegate this to someone else? This was the issue involved in item 23 of the survey. The respondents were very unified at a median value of 2.40 . While favoring the plan, it appears that many respondents may 
prefer to leave the matter to the pastor to decide. The conference group was more adamant in its opinion, 2.03 , whereas the laity were less at 2.48 on the scale. Apparently this is an activity that many laymen feel only the pastor has the skill to do. It requires more than skill, however, to make up articles and submit them to the local news outlets. A burning desire to let the community know more about the local congregation is also essential.

As to whether the pastor himself should make most of the contacts with the news media, there was less unity among the respondents. The total sample leveled at the 3.06 median point. This is slightly in favor of the "may not" of the "may or may not" point of the scale, The over-fifty-year-old group and conference group appear to be more opposed to the pastor making most of the new media contacts, whereas the under-fifty and total-laity groups were more in favor. Perhaps the younger group are much in favor of some contact but feel unqualified to perform the task. The conference group seems inclined to urge someone other than the pastor to perform such tasks, perhaps with the thought in mind that the minister has the more professional work of teaching and preaching to do. The writer is inclined to agree with his conference brethren, but with the stipulation that if the work concerning contact with the news media is delegated, the person chosen to do the work should be adequately trained beforehand. The ability of the pastor, the willingness on the part of the public relations secretary, and the concern that the church let 
its light shine in the community are all key factors to a successful public relations program.

The Pastor and Civic Involvement

Another item on the questionnaire involves the pastor's relationship to civic issues. This is item 72 of part II of the questionnaire. Table 19 gives the number of responses and Chisquare test results from the seven subgroups compared.

Of all the issues discussed on the survey form, item 72 created more significant differences among subgroups than any other item. Five of the seven pairs of subgroups had significant differences over the pastor's part in public issues.

Item 72 states that in public controversies involving such issues as national or community elections, tax support for parochial schools, or racial prejudice in suburban real-estate dealings, the pastor should either actively engage in promoting his opinion on the issues through organizations, circulation of petitions, and so forth (answer A), or he should have his opinions but avoid becoming involved at all in such matters and stick to preaching the three angels' messages (answer B).

The response indicates that the majority of the respondents oppose answer A and favor answer B on the above issue. However, as will be noted in table 19, even though most of the groups favor answer $B$, there is a wide degree of intensity in their responses. While the officer-and-deacon/conference groups were in total agreement, the over-fifty/under-fifty age groups were in total disagreement. The only other pair of subgroups that agreed were the 
TABLE 19.--Number and percentage of responses by congregation and ministers concerning involvement in civic affairs of the pastor of the Grand Rapids Central SDA church in reply to the statement: How should the pastor relate to national or community elections, social injustice and public controversies?

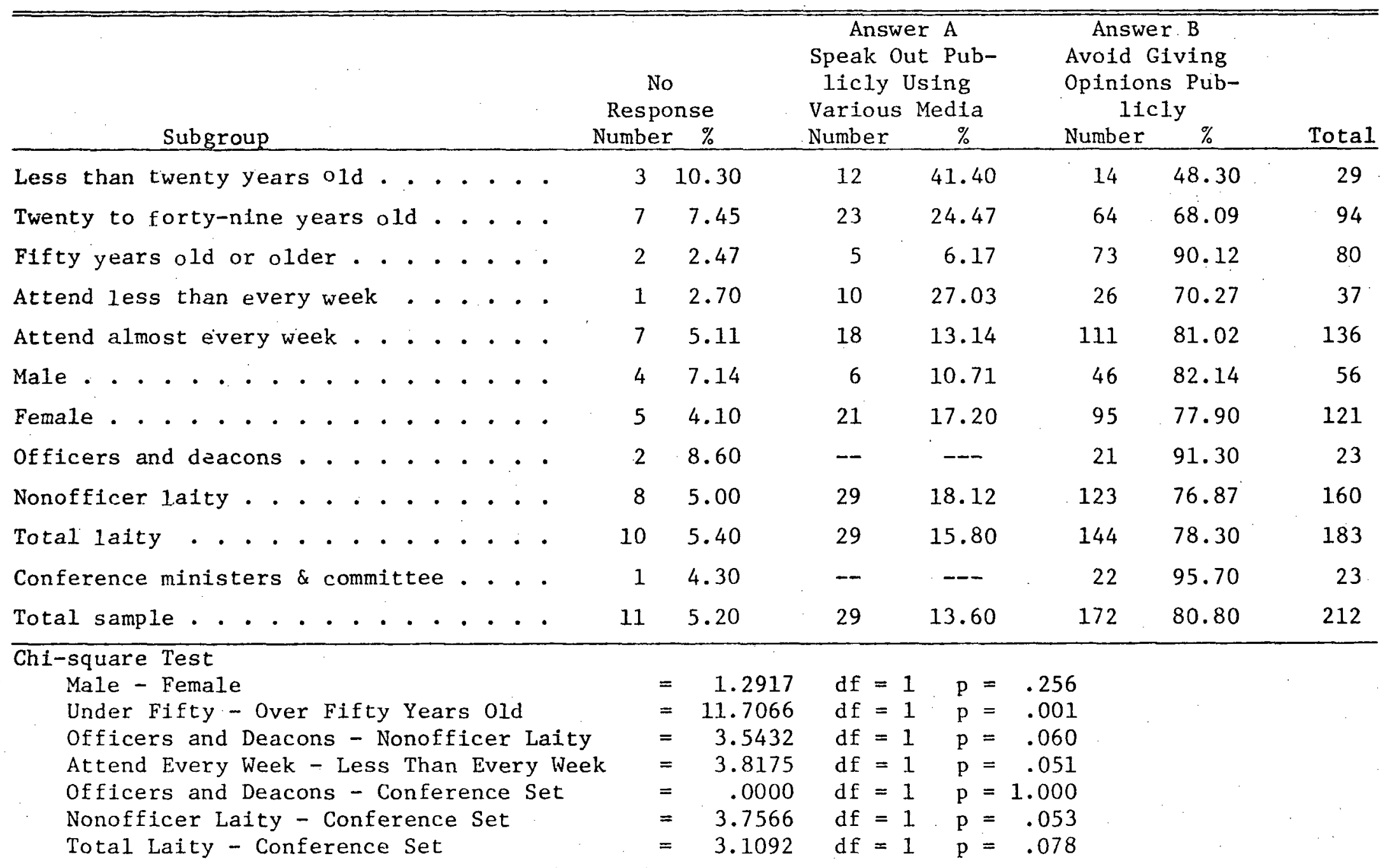


male/ferale subgroups. It appears that there is a strong feeling among the leadership of the SDA church, officers, deacons, ministers, and conference officials, that the pastor of the focal church should avoid involvement in public issues.

In view of the conservative, antisocial-gospel mentality that exists within the SDA church, it is noteworthy that 15.8 percent of the total laity favor answer A, which involves the pastor in aggressive activity on public issues in his local community. However, nearly half of these are from the under-twenty-year-old age group. The possibilities of conflict for the pastor are obvious, particularly as one observes the position of the conference and the older members and the younger members of the church. A negotiative approach to this problem could prove useful.

Summary Concerning the Pastor and Community Relations

From the above analysis it appears that the majority of the respondents prefer that the pastor not participate in service clubs such as Kiwanis nor act as a press agent. Considerable difference of opinion seems to exist between certain pairs of subgroups on these matters. Also there is not a high degree of preference that the pastor belong to the local ministerial association even though the majority did favor the idea. Finally, it appears that there is serious disagreement between many of the respondents from the church and conference as to how involved the pastor of the focal church ought to be in public issues. 
The majority clearly opposes the pastor being involved in public and social issues in the community. It is particularly striking that not one of the conference committee members or ministers approves of the pastor's being involved in public issues. This is even more unusual when one notes that the majority of ministers in other Protestant denominations favor being involved in public and social issues of their community. ${ }^{1}$. While conflict over this matter seems to be present to a degree in the SDA church and conference, yet it does not appear to be as serious as it has become in other denominations.

The impression from the analysis is that a strong segment of the respondents in this survey would prefer the local pastor to be somewhat uninvolved in community affairs. Perhaps the group surveyed perceives that the short tenure of most of the pastors of this church would preclude much community involvement. ${ }^{2}$ Certainly it takes more than two and one-half years for the pastor to become very well acquainted with many in a community the size of the one in this study.

Because the SDA church is heavily oriented to sharing a special biblical message with the world, one program of the pastor usually receives a ready response. It is the evangelistic and outreach program. It is to this matter the following section is dedicated.

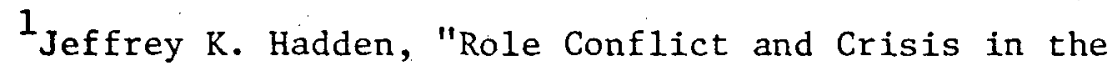
Churches," Ministry Studies, Vol. II, nos. 3 and 4, December 1968, p. 20. 


\section{Section III--Concerning the Pastor's Evangelistic and Outreach \\ Expectations}

Since the Seventh-day Adventist church was organized in 1863, it has grown from a small group of thirty-five hundred members to nearly three million. ${ }^{1}$ There is a reason for this growth. The SDA church has accepted as its mandate the commission of Jesus Christ recorded in Mt 28:19: "Go ye therefore, and teach all nations, baptizing them in the' name of the Father, and of the Son and of the Holy Ghost." A strong urgency to fulfill this commission characterizes the movement.

At the 1976 Annual Council of Seventh-day Adventists the church gave impetus to this aspect of its mission by taking a specific action concerning Evangelism and Finishing God's Work. 2 The main thrust of the action is that the local conferences are to engage more personnel and devote more funds to the evangelistic outreach of the denomination.

According to the document, evangelistic work is defined as

The communication of the essential elements of the gospel of 'Jesus Christ in the setting of the three ange1s' messages in such a way as to make possible a resposne in the hearts of the hearers to accept God's provision of salvation from sin and His provision for victory over $\sin .^{3}$

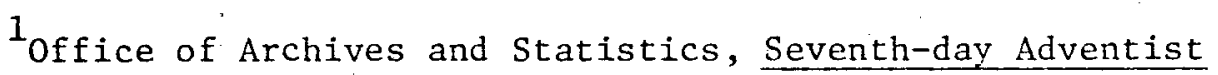
Yearbook (Washington, D.C.: Review and Herald Publishing Assoc., 1976), p. 4 .

2"Actions of General Interest From the 1976 Annual Council," Review and Herald, December 2, 1976, p. 14.

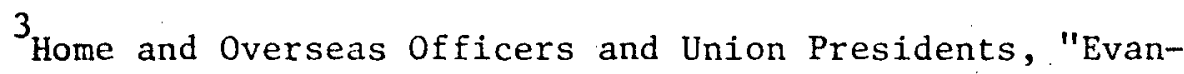
gelism and Finishing God's Work," paper presented at the 1976 Annual Council of the General Conference of Seventh-day Adventists, 14 October 1976 , p. 26. 
The above definition indicates that evangelism means a direct confrontation with the claims of the Bible and Jesus Christ. It is a direct, personal confrontation that seems to be called for in the definition rather than an indirect, impersonal activity. The church, Adventists believe, exists to evangelize. ${ }^{1}$

Because of the magnitude of the task and because Jesus Christ has promised to return when the gospel is carried to the world, a spirit of urgency characterizes all that the church does. This urgency has its influence upon the SDA pastor. It may stimulate him to give more of himself to his work than if his theology concentrated more upon the "here and now." But the SDA pastor works under the overarching dome of the imminent return of Christ. His chief source of counse1, Ellen G. White, has set the tone of his eschatological concepts in such words as

Now is the time for the last warning to be given. . . . Decided efforts should be made to bring the message for this time prominently before the people. The third angel is to go forth with great power. . . .2

Another reason the local SDA pastor actively engages in working for the unconverted is for the good of his own experience. He is aware that "it is in working to spread the good news of salvation that we are brought near to the Saviour. ${ }^{3}$

Finally, the pastor, like his fellow members in the church, is concerned that the church does not become Laodicean (Rev $3: 14-17$ ).

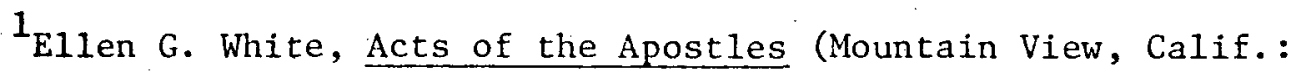
Pacific Press Publishing Assoc., 1911), p. 9.

2 White, Testimonies, $6: 16$.

$3^{3}$ White, Desire of Ages, p. 340. 
This may serve to stimulate the pastor to engage in seeking the lost. The danger is that of being lulled to sleep and "following the fearful trend of the early church."1

One of the intentions of the annual council action, "that the role of the pastor be clarified," ${ }^{2}$ is relevant to this study. It appears, according to the document on evangelism and finishing God's work, that the role of the pastor has already been determined. It is to be primarily an evangelistic role, as stated in the following: "Church policy shall clearly state that the pastor-evangelist's first work and that for which he be held accountable is the giving of the gospel of Jesus Christ in the setting of the three angels' messages." ${ }^{3}$

In view of the above concept concerning the role of the pastor certain questions arise. If the pastor is to be primarily an evangelist, does he abdicate his position as pastor before his parishioners? Are the two functions complementary or mutually exclusive? Is it possible that some are called to be pastors without being called to be primarily evangelists? Will all pastors be able to be "freed" from administrative responsibilities and other so-called "encumbrances" in order that they may engage in evangelistic activity? How does the church see the pastor in this regard? Can the local churches be expected to respond

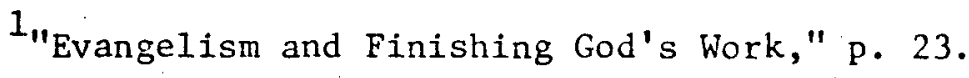

2 Ibid., p. 27 . 3 Ibid.
} 
positively to the call for the pastor to become primarily an evangelist?

The comments of two of the respondents may indicate how some laymen feel about their pastor engaging in evangelism for nonmembers. One respondent wrote, "I feel that most pastors are more interested in obtaining new members than they are in keeping the old ones." 1 Another wrote, "I feel if as much or even half as much time and effort was spent to visit and win back discouraged members as is spent trying to win even one new member, it would be great for our church." 2

Just what should the local SDA pastor do? Will he be able to meet the wants of his congregation if he complies with the recommendation of the Annual Council action of the General Conference? Must every local pastor comply to an equal degree and do evangelistic work or is this a matter for negotiation? To some of these questions section III of the survey form is directed.

The five items, numbers 25-29, on the survey form deal with evangelistic and outreach expectations for the focal pastor of this study. They include issues relating to public evange1istic meetings, personal Bible teaching work, training laymen for witnessing, and making initial evangelistic contacts. Table 20 gives the median scores for each of the subgroups and the total

\footnotetext{
${ }^{1}$ See exhibit $B$, number 61 .

${ }^{2}$ See exhibit B; number 201 .
} 
TABLE 20.--Median responses of the congregation, conference committee, and certain ministers concerning evangelistic and outreach expectations of the Grand Rapids Central SDA pastor

Instrument
Number and Statement

25. Either the pastor or another conduct an annual

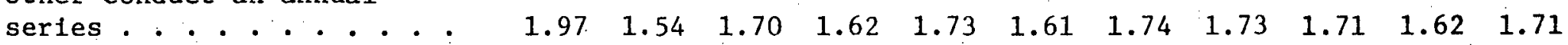

26. Do Blble study work for nonmembers . . . . . . .

27. Give on-the-job training in witnessing . . . . . .

28. Let others make initial contact with nonmembers... .

29. Do more training of others than actual evangelism himself . . . . . . .

$\begin{array}{lllllllllllll}1.86 & 1.95 & 2.35 & 2.33 & 2.07 & 1.93 & 2.16 & 1.91 & 2.22 & 1.55 & 2.08 \\ 2.23 & 1.78 & 2.03 & 1.83 & 2.06 & 1.80 & 2.03 & 1.92 & 2.07 & 1.27 & 1.95 \\ 2.54 & 2.28 & 2.41 & 2.22 & 2.45 & 2.31 & 2.42 & 2.79 & 2.38 & 2.13 & 2.37 \\ 3.12 & 2.81 & 3.04 & 2.72 & 3.06 & 2.80 & 3.06 & 2.75 & 3.06 & 2.55 & 2.97\end{array}$

Median figures are based on a range of one to five as follows: 1 - Absolutely must 2 - Preferably should 3 - May or may not 4 - Preferably should not 5 - Absolutely should not 
sample based on the one-to-five-point scale. The reader is directed to this table in the discussion that follows.

Concerning the Conducting of

Public Evangelistic Meetings

Item 25 states that the pastor himself should conduct or arrange to have another conduct at least one evangelistic or revival series each year in the local church. The responses from the total sample indicate a high degree of interest in such a plan at a 1.71 score. There was little disagreement among the subgroups concerning this issue. The middle-age group, twenty to forty-nine years old, were slightly more insistent than the rest of the groups, at 1.54 on the one-to-five scale. The burden of the laity for public evangelism is indicated by one respondent's suggestion to "Love all men and join in with our brothers and sisters wherever possible. Hold united crusades with all churches in our district and let's see God do miracles in your life and others. "1

There was less unanimity, however, between the subgroups in their responses to item 26 of the survey form. This iter is concerned with the pastor personally conducting Bible lessons for nonmembers in their homes. The total sample scored 2.08 on the one-to-five scale. However, the conference group was somewhat more insistent at 1.55 on the scale, indicating the pastor almost "absolutely must" engage in this form of evangelism.

${ }^{1}$ See exhibit $B$, number 50 . 
The over-fifty age group, at 2.45 , half way between "preferably should" and "may or may not" point of the scale, indicate they have less desire to see their pastor do personal Bible teaching to nonmembers. This may be seen as a slight trend among the older age group to avoid direct contact with the nonmember public, since they also were inclined to prefer that the pastor avoid public issues as well. ${ }^{1}$ Perhaps they see the pastor having enough to occupy himself within the congregation without taking on the additional burden of working for nonmembers. The potential conflict for the pastor exists, however, in the fact that he has been advised that "Our ministers are not to spend their time laboring for those who have already accepted the truth."2

Concerning the Training of the Laity for Witnessing

One of the concerns of the new revival of evangelism, according to the paper already referred to, is that the pastor conduct lay witnessing training programs in his church. It states that "Pastors who lead churches shall accept the responsibility of training and organizing all laypersons in the church for involvement in effective pre-evangelistic action with conference assistance in harmony with the Spirit of Prophecy instruction." 3

How does the local congregation of this study and the conference group see this facet of the pastor's work as stated

${ }^{1}$ See p. 4 - Concerning pastor's public relations expectations.

2 "Evangelism and Finishing God's Work," p. 27. ${ }^{3}$ Ibid. 
in item 27 of the survey form? The item suggests that the pastor should engage in a type of on-the-job house-to-house visitation and Bible-teaching approach to witnessing. Al1 subgroups of the sample responded at "preferably should," or 1.95 on the scale. The conference group was somewhat more intense at a 1.27 score. The pastor may be pleasing his conference peers and officials by engaging in on-the-job witnessing training. There appears to be, however, a sizeable group of laymen who are unconcerned with this type of training. The challenge for the pastor will be to stimulate this group to participate in some other form of witnessing.

From what is stated above it appears the local SDA pastor may find himself doubly burdened. On the one hand he is told that he is "not to spend his time.. laboring for those who have already accepted the truth," and then he is urged to "train and organize all laypersons in the church." The potential conflict for the local SDA pastor is very obvious. The need for negotiation is paramount at this point. Also a more complete understanding of what is meant by certain statements from the writings of E11en G. White may be in order.

It appears from the responses to item 28 of the survey form that there is general agreement among the respondents that someone other than the pastor should make the initial contact with evangelistic prospects referred to the pastor from the Michigan Conference office. The total sample, however, was not overly strong on their insistence for this, at a 2.37 score. It is quite possible that many would like to leave such decisions up to the pastor. It 
appears to be a duty that could be negotiated and that the pastor may find someone willing to help him in this activity. It appears that the laity were somewhat less enthusiastic in their willingness to do this work at a 2.38 score than was the conference group at 2.13 on the scale, That is understandable due to the lack of training many laymen have for this type work.

Finally, how should the pastor of the focal church relate to personally conducting public evangelistic meetings? From the responses to item 29, there are potentials for conflict over this issue. The item states that the pastor should spend most of his time helping church members be good witnesses rather than conducting public evangelistic meetings. The total responses leveled at a 2.97 median point, or almost at the "may or may not" response. The "may or may not" point on the scale may indicate that about half favor the pastor engaging in public meetings and about half favor his spending most of his time training others to witness. On the other hand, it could also mean that most respondents actually checked the "may or may not" response. Regardless, the pastor is left to either decide for himself whether he will spend more time conducting public evangelistic meetings or more time training his laymen in witnessing. It may provide an area for negotiation between the pastor and his role set.

A Summary Concerning Evangelistic and Outreach Expectations of the Focal Pastor

In summary, the respondents in this survey reflect a significant interest in the pastor engaging in personal and public 
evangelistic activity. Only a small minority consider it an optional activity for the pastor.

However, it appears that the laymen themselves seem to consider evangelistic and outreach activity somewhat optional as far as either participating themselves or being trained on-the-job. There was somewhat less desire of the laymen to make initial contacts with evangelistic prospects.

The picture that emerges is that most laymen favor the church being evangelistic as long as the pastor is the chief evangelist and witnessing trainer. There also appears to be some reticence on the part of the laymen to even engage in some form of witnessing training. Perhaps, under the present conditions, it would be unwise to insist that they do. There is much indirect soulwinning work to be done. This might well be an area for negotiation so that assignments may be made which more nearly fit the natural abilities of the laity.

It appears that the type of evangelistic work suggested by "Evangelism and Finishing God's Work" is the most favored ministry in the which the local SDA pastor can engage. This is the concept held by the general leadership of the local church, conference, and the denomination. However, as good as this may be, there are other activities in which the local pastor is expected to engage his energies, time, and talents. Among these are his personal counseling and pastoral visitation responsibilities. Several questions on the survey form involve these duties. The study now directs itself to an analysis of the responses concerning those questions. 
Section IV--Concerning Counseling and

Pastoral Visitation

Pastoral counseling today has become a separate science in itself. The writer is impressed that among SDA pastors today there is a general acceptance of this as one of his functions. Most seminary trained SDA pastors have been exposed to the field of counseling. Clinical Pastoral Education courses are available to SDA pastors within the denomination's educational system.

Pastoral counseling is defined as:

The utilization, by a minister, of a one-to-one or small group relationship to help people handle their problems of living more adequately and grow toward fulfilling their potentialities. This is achieved by helping them reduce the inner blocks which prevent them from relating in needsatisfying ways. 1

Pastoral visitation is closely allied to pastoral counseling. Many of the same skills are used in pastoral visitation that are used in pastoral counseling. They are, therefore, discussed together in this section of this study.

Pastoral visitation must be defined in terms of the way it is referred to in the New Testament. "The New Testament word for visit is episkeptomai. Forms of this work occur eleven times (Mt $25: 36,43 ;$ Lk $1: 68,78 ; 7: 16$; Acts $6: 3 ; 7: 23 ; 15: 14,36$; Heb $2: 6$; Jas $1: 27) . " 2$ In Acts $6: 3$ the word is translated "look out." In every other reference it is translated "visit." Pastoral visitation must be defined as "to go to see, to inspect . . . a

$1_{\text {Howard J. Clinebell, Jr., Basic Types of Pastoral }}$ Counseling (Nashville: Abingdon Press, 1966), p. 20.

${ }^{2}$ Robert G. Witty, Church Visitation: Theory and Practice (Nashville: Broadman Press, 1967), p. 11. 
Christian service whereby Christians go or come to other persons in order to understand their needs and assist them with adequate help found only in Christ." 1

As dual functions of the pastor, pastoral counseling and pastoral visitation are to minister to the spiritual, mental, and emotional needs of his parishioners.

There has always been the sickness of the mind and body as well as a sickness of the soul. There has always been someone designated to care for the people of God as a shepherd cares for his sheep. The purpose is to assist in healing those who may be sick in body, soul, or mind.

In the twentieth century pastoral psychology has become a highly developed science. Mental, emotional, and spiritual illness have new explanations in the light of this new science, and therefore new methods of healing should be applied. Instead of the sickness being attributed only to spiritual causes, a more sophisticated explanation is given. This makes the treatment of sickness more complex as well. This has implications for the local pastor. How one sees the origin of a soul-sickness determines how one seeks a cure for it.

That a wide range of spiritual, emotional, and mental problems and personal needs exists within the membership of many SDA congregations is evident from the personal experience of the writer as a pastor. The church faces the challenge of an unfinished task of giving the gospel message to the world. The pastor is faced with 
the challenge of preparing his people for this task. The question facing him i.s whether he should urge his members to engage in witnessing to their neighbors and friends while they are crippled in their ability to relate well with others. What is needed is some way of knowing how to become a more capable witness. Perhaps by personal counseling and visitation the pastor may provide this help. "Counseling and visitation aims at helping a person increase his ability to love God, his neighbor and himself more fully."1

In the light of the above, the pastor today is faced with the challenge of developing his counseling and visitation skills. Is it what he does or who he is that is most important? How he answers this will determine what resources he will utilize in his pastoral work. If he feels it is what he does, then he will draw from the fields of psychology, behavioral science, and religion. If he feels it is what he is, then he will depend more upon the spiritual resources with a greater expectation of the miraculous in the healing process.

The tension existing between these two approaches of the pastor to his pastoral work is reflected in question 71 , part II, of the survey form. Also, question 74, part II, of the survey involves the counseling work of the local pastor. Before discussing section IV, items $30-44$ of the survey form, these two issues concerning counseling resources and methods will be examined.

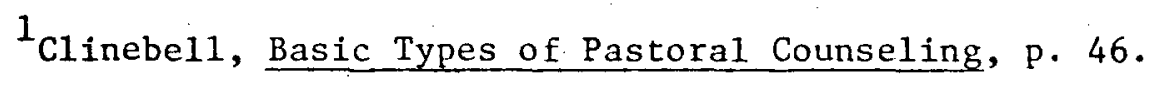


Analysis of Techniques and Resources for Counseling

The two items, numbers 71 and 74 , part II, concern the pastor's counseling resources and methodology. The reader is directed to table 21 for the number of responses and percentages to the issue discussed in number 71 and table 22 for the issue discussed in number 74 .

Table 21 provides a clear picture of frequency responses, percentages, and Chi-square tests for certain pairs of subgroups surveyed in this study concerning counseling resources for the pastor. The respondents were given two choices in their response to this item. The A response indicated utilizing psychological and technical information concerning human nature along with the spiritual resources, whereas the $B$ response showed a preference for the pastor to utilize only spiritual resources in his counseling and pastoral care. There were 55.4 percent of the respondents who chose answer B and 38.5 percent who chose answer A. It appears a slight majority prefer the pastor to rely totally upon spiritual resources in his pastoral care.

However, a closer look at table 21 reveals that certain of the subgroups are diametrically opposed to each other. This indicates that there is considerable difference of opinion among the respondents as to what resources the pastor should use in his counseling work. For instance, 60.9 percent of the nonofficer laity were in favor of answer B, whereas 39.1 percent of the officers and deacons and 43.5 percent of the conference group favored answer B. The over-fifty age group were even more in 
TABLE 21.--Number and percentage of responses by congregation and mintsters concerning the pastoral counseling concepts of the pastor of the Grand Rapids Central SDA church in reply to the statement: What resources in counseling skills should the pastor use in his work?

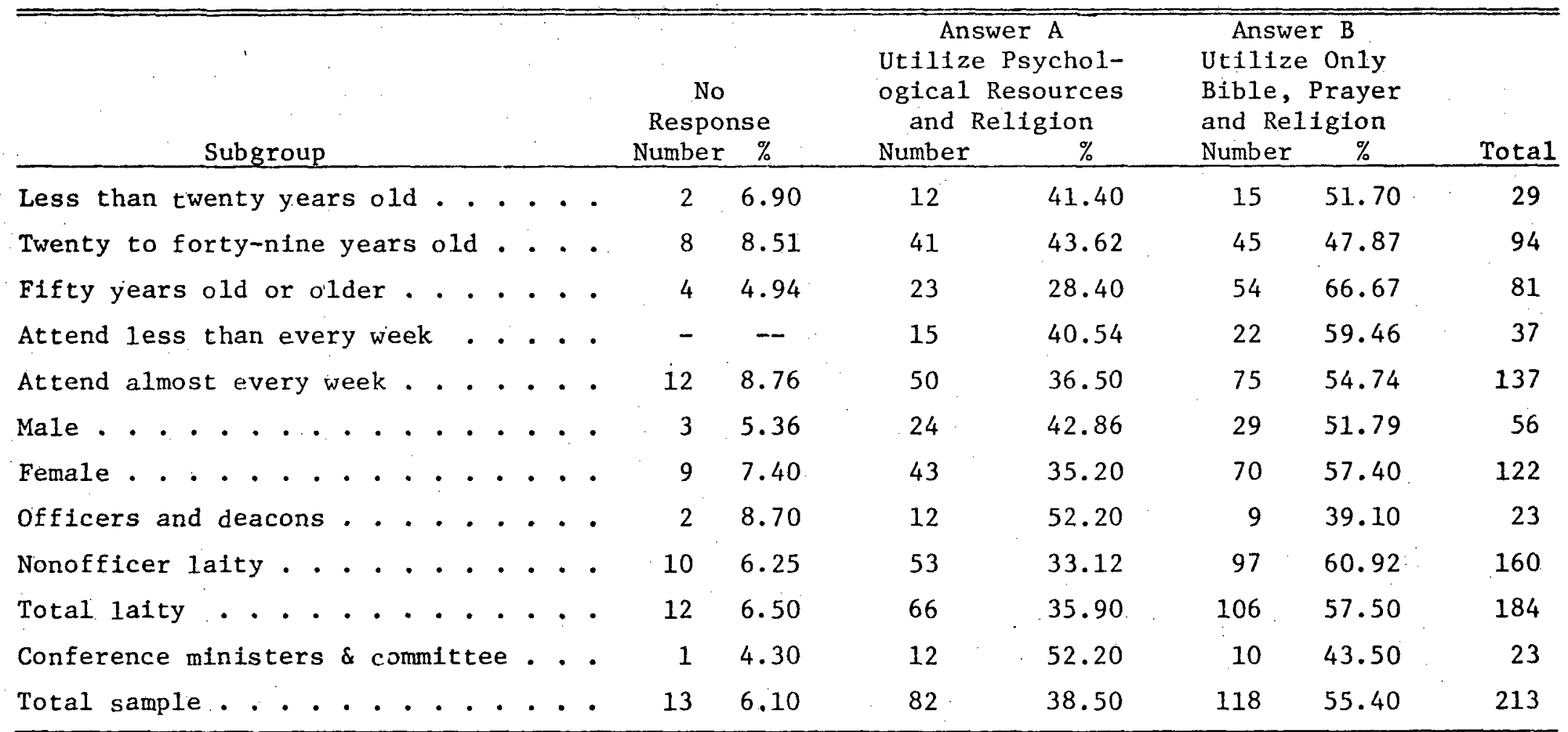

\begin{tabular}{lllll}
\hline Chi-square Test & $=.9572$ & df $=1$ & $\mathrm{p}=.328$ \\
Male - Female. & $=5.4002$ & $\mathrm{df}=1$ & $\mathrm{p}=.020$ \\
Under Fifty 0 Over Fifty Years old & $=4.5793$ & $\mathrm{df}=1$ & $\mathrm{p}=.032$ \\
Officers and Deacons - Nonofficers Laity & $=.0035$ & $\mathrm{df}=1$ & $\mathrm{p}=.953$ \\
Attend Every Week - Less Than Every Week & $=.0962$ & $\mathrm{df}=1$ & $\mathrm{p}=.761$ \\
Officers and Deacons - Conference Group & $=3.0123$ & $\mathrm{df}=1$ & $\mathrm{p}=.083$ \\
Nonofficer Laity - Conference Group & $=2.1223$ & $\mathrm{df}=1$ & $\mathrm{p}=.145$
\end{tabular}


NUMBER 22.--Number and percentage of responses by congregation and mintsters concerning pastoral counseling methods of the pastor of the Grand Rapids Central SDA church in reply to the statement: What approach is best when counseling persons with personal or moral problems?

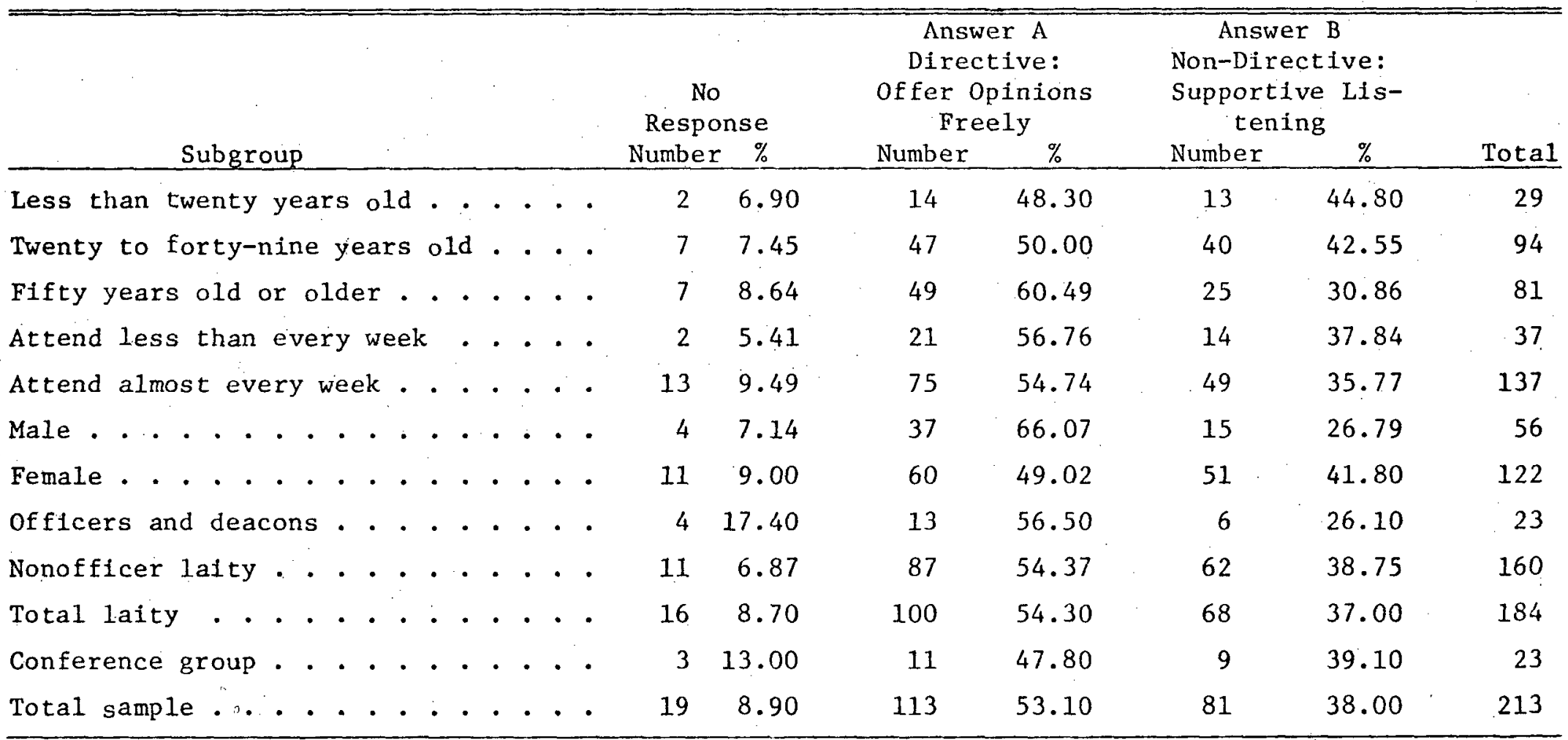

\begin{tabular}{|c|c|c|c|c|}
\hline \\
\hline Male - Female & $=4.4311$ & $\mathrm{df}=1$ & $\mathrm{p}=$ & .035 \\
\hline Under Fifty - Over Fifty Years Old & $=2.4696$ & $\mathrm{df}=1$ & $\mathrm{p}$ & .116 \\
\hline Officers and Deacons - Nonofficer Laity & .7039 & $\mathrm{df}=1$ & $p=$ & .401 \\
\hline Attend Every Week - Less than Every Week & .0027 & $\mathrm{df}=1$ & $p$ & .959 \\
\hline Officers and Deacons - Conference Group & .7415 & $\mathrm{df}=1$ & $\mathrm{p}$ & .389 \\
\hline Nonofficer Laity - Conference Group & $=1.7461$ & $\mathrm{df}=1$ & $\mathrm{p}$ & .773 \\
\hline Total Laity - Conference Group & .1512 & $\mathrm{df}=1$ & & .697 \\
\hline
\end{tabular}


favor of answer $B$ with 66.6 percent preferring the pastor use only spiritual resources in his pastoral ministry. On the other hand, among the under-fifty age group only 47.8 percent favored answer $B$. It appears that terms such as psychology and the study of human nature tend to be unpopular among the older laity whereas the church officers, deacons, and the conference group are less intimidated by these terms. The writer would certainly disagree with the majority of his laymen in his response to this issue and choose answer A. If the science of psychology is a science of the human mind and it is good in its place, ${ }^{1}$ perhaps it is not wrong to become acquainted with the science at least to the extent of knowing what constitutes human normality.

It appears that some of the aversion to the field of psychology among the laymen, older-age groups, and a large portion of the respondents stems from their indoctrination that psychology is dangerous. This may be the result of the statement of E1len $G$. White: "Satan comes more directly to this generation to ruin souls through the science of psychology." 2 The ministers and officers may have read the balancing statement, which says, "the sciences having to do with the human mind are good in their place." 3

Item 74 has to do with the question of whether the pastor should use a directive or nondirective counseling approach when

${ }^{1}$ E1len G. White, Selected Messages, $2: 352$.

2E1len G. White, Testimonies, 1:296:

${ }^{3}$ Ellen G. White, Selected Messages, 2:352. 
seeking to help persons who have mental, emotional, or spiritual problems. Even though there was much difference of opinion, 53 percent of the respondents were favorable to answer $A$, the directive counseling method. A strong segment, 38 percent, were in favor of answer $B$, the nondirective method of counseling.

One unusual feature, as revealed in Table 22, indicates that a conflict exists between the male and female respondents concerning the pastor's counseling methods. The male group were highly in favor of answer A, the directive approach, with 66 percent choosing that response, whereas only 49 percent of the women chose answer A. It appears that more of the women prefer to see the pastor as a sympathetic listener rather than a solver of their problems. More of the men, on the other hand, appear to prefer to be told by the pastor what to do. The writer is inclined to agree with the women in most counseling situations. There may be exceptions when a person needs the experience and knowledge of the pastor to help him make up his mind, and that would require the directive approach. However, in most cases of mental, emotional, and spiritual difficulty, the nondirective counseling approach is more effective and helpful.

Expectations of the Pastor in Times of the Crises of Sickness and Death

Traditionally the pastor is expected to give support and comfort in times of sickness and death among his parishioners. Six items concerning the pastor's functions during these times were included in the survey. A highly unified response was received from 
these questions. Table 23 gives the median responses for the total sample and subgroups.

Statement 30 , that the focal pastor should visit a seriously i11 person immediately upon learning about it, received a favorable response at a 1.60 , or between "absolutely must" and "preferably should" value on the one-to-five scale. The respondents were also favorable to statement 32 concerning pastoral visiting with the family of the deceased member at the time of death. The total sample scored 1.29 on the scale indicating slightly more insistence that the family of the deceased member be visited immediately than when a member is reported seriously ill:

The respondents were consistent in opposition to the pastor waiting until called before visiting the sick, as is stated in item 31 of the questionnaire. The total sample scored 3.94 on the one-to-five scale at "preferably should not." It appears that the respondents consider the pastor an important part of the healing team.

How frequently should the pastor visit the hospitalized member of the focal church? The statement in item 33 that the pastor should visit the terminally ill frequently but not daily received a "preferably should" response at 1.93 on the scale. There was a high degree of unity among the subgroups in their responses.

The respondents were also in favor of statement 34 that the pastor should visit hospitalized members only one or two times in a ten-day stay. There was no strong insistence on the part of 
TABLE 23.--Median responses of the congregation, conference committee, and certain mintsters concerning pastoral and visitation expectations of the Grand Rapids Central SDA pastor

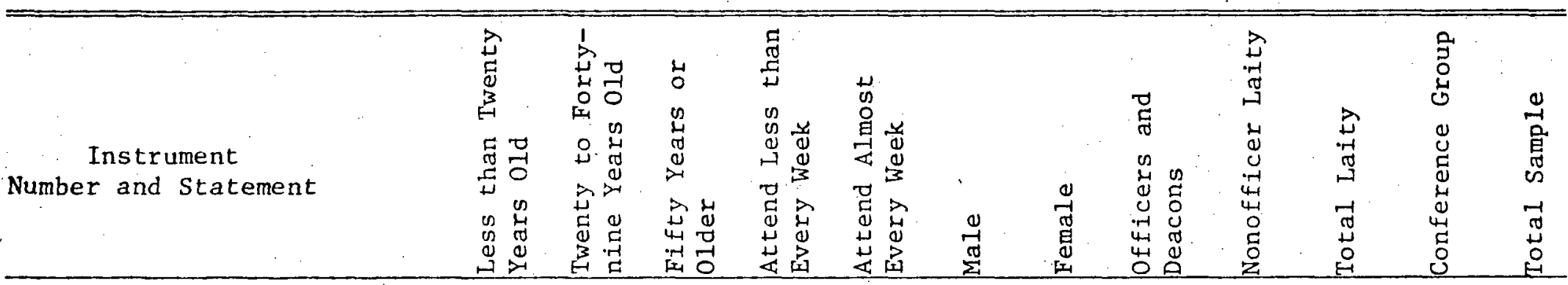

30. Immediately visit those reported seriously 111 .

$\begin{array}{llllllllllll}1.80 & 1.56 & 1.54 & 1.56 & 1.63 & 1.49 & 1.64 & 1.65 & 1.60 & 1.64 & 1.22 & 1.60\end{array}$

31. Wait until requested before visiting the ill $\quad \begin{array}{llllllllllll}3.50 & 4.15 & 3.89 & 4.21 & 3.84 & 4.12 & 3.79 & 4.05 & 3.94 & 3.88 & 4.44 & 3.94\end{array}$

32. Visit family of deceased $\begin{array}{lllllllllllll}\text { at the time of death } . ~ & 1.70 & 1.24 & 1.23 & 1.24 & 1.31 & 1.21 & 1.33 & 1.17 & 1.29 & 1.30 & 1.18 & 1.29\end{array}$

33. How frequent should pastor visit terminally ill? $\quad \begin{array}{lllllllllllll}2.08 & 1.87 & 1.92 & 2.03 & 1.87 & 1.97 & 1.88 & 1.59 & 1.93 & 1.91 & 2.00 & 1.93\end{array}$

34. How frequent should he visit hospital patient?

752.62

622.57

$57 \quad 2.41$

412.66

$\begin{array}{lllllll}2.69 & 2.55 & 2.86 & 2.62 & 2.59 & 2.85 & 2.62\end{array}$ town SDA hospital

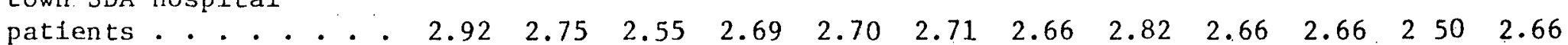

36. What is the best way to bring unity in the $\begin{array}{lllllllllllllllllllll}\text { church? } & . & . & . & . & . & 2.67 & 2.30 & 2.08 & 2.25 & 2.27 & 2.11 & 2.29 & 2.06 & 2.27 & 2.30 & 2.05 & 2.27\end{array}$

37. What is the best way to

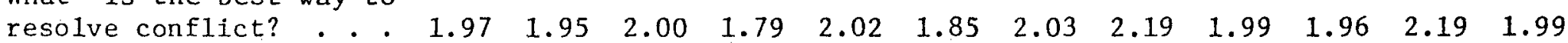

38. Pastor should visit shut-

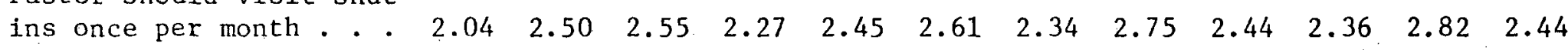


TABLE 23 (Continued)

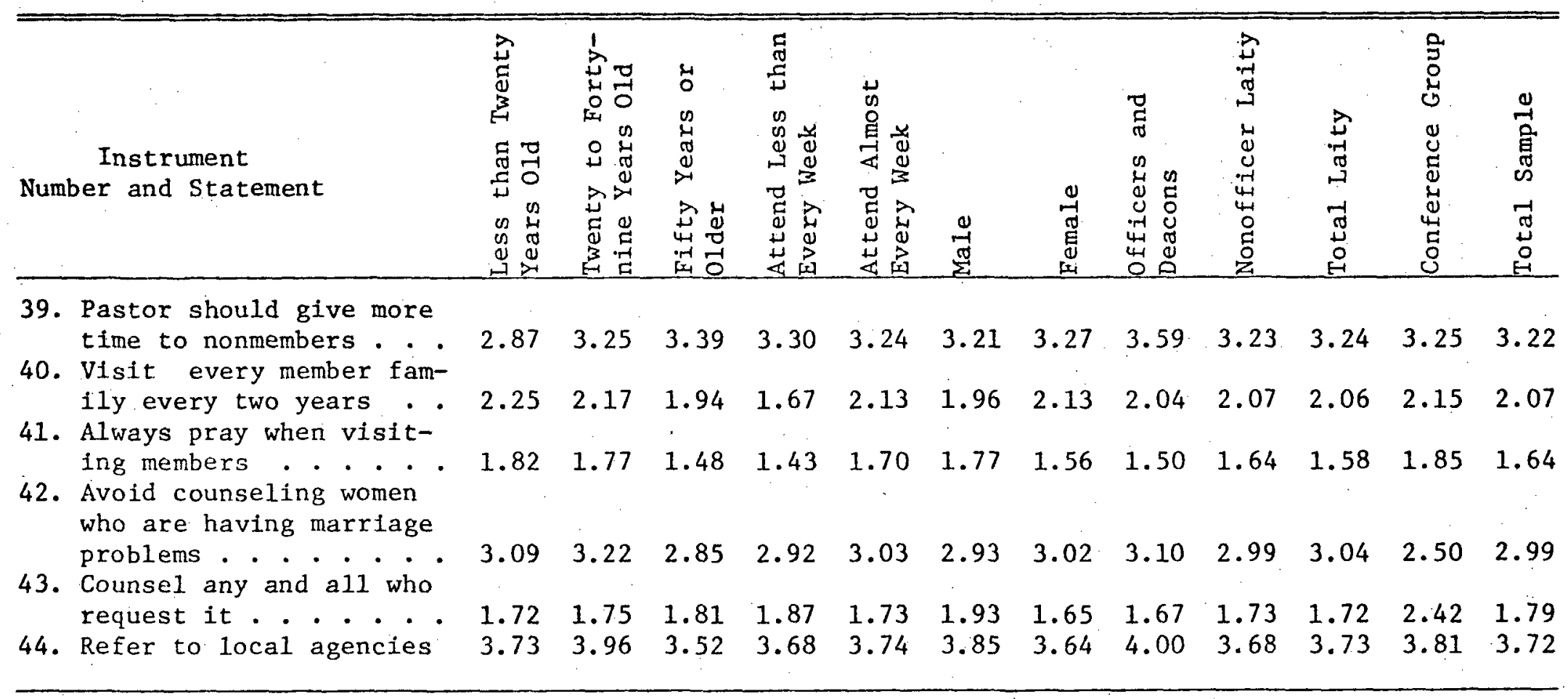

Median figures are based on a range of one to five as follows: 1 - Absolutely must 2 - Preferably should 3 - May or may not 4 - Preferably should not 5 - Absolutely should not 
the total sample at 2.62 which reveals that many respondents favor a "may or may not" response.

As mentioned earlier in the study, a group of hospital patients that often expect visits from the focal pastor are SDA members from surrounding cities and towns. Requests come from fellow pastors and loved ones of the patient for the focal pastor to go and visit their member or loved one in one of the city's hospitals.

Statement 35, concerning the respondent's reaction to this duty of the focal pastor, received a favorable response. However, it was not strong at a 2.62 value on the scale. While the pastor should include these members of other SDA churches, it appears that in the minds of the respondents there is less insistence that he should do so.

From the above analysis of the responses it appears that the respondents to this survey consider the focal pastor an important part of the emergency team in times of crisis. This may pose serious. time problems to the focal pastor. As his congregation increases in numbers the calls also increase for his services in times of crises. Unless the pastor can devise some form of negotiated ministry that releases him from time to time, he will be overloaded with such activities and unable to engage in his other duties, such as evangelism. One plan that might possibly be used Is a crisis chaplaincy assignment for the local elders of the church. Such a plan was initiated by the writer as pastor of the church during his time there. It was attended with some degree of success. 
Analysis of Responses Concerning the Focal Pastor's Role in Times of Conflict

Traditionally, the Christian church has sought to reduce, as far as possible, all forms of conflict. The cry for unity in the church was first made by its originator, Jesus Christ (Jn 17:23). However, Jesus was aware that conflict would be a part of the tribulation of the church down through the ages (Jn 16:33). History pictures the church often beset by conflict both within and without its borders.

Is conflict always bad? Some think so, others do not. One writer states, "I am sure that we can begin by agreeing that every major advance in civilization has resulted from conflict." 1 Others point out that only by a complete unity will the church achieve its goals. "God designs that His people shall be a unit; that they shall see eye to eye, and be of the same mind and of the same judgment." 2 Also the same writer declares that "the strongest witness that God has sent his Son into the world is the existence of harmony and union among men of varied dispositions who form His church." 3

Because of his position and influence the pastor is a key person to create conflict in the church or enhance its unity. Much depends upon the pastor's own way of managing conflict.

$1_{\text {Ross Stagner, quoted in Speed Leas and Paul Kittlaus, Church }}$ Fights (Philadelphia: The Westminster Press, 1973), Frontispiece.

${ }^{2}$ Ellen G. White, Radiant Religion (Washington, D.C.: Revlew and Herald Publishing Assoc., 1946), p. 109.

3E11en G. White, Conflict and Courage (Washington, D.C.: Review and Herald Publishing Association, 1970), p. 357. 
Item 36 of the survey form states that the pastor should seek unity by preaching powerful sermons on unity. The repondents tend to favor such sermons as reflected in the nearly, "preferably should," or 2.27 point of the one-to-five scale. A goodly number appear to prefer this to be a matter for the pastor to decide in that the median point is near to the center, or the "may or may not" response.

The respondents were more in favor of the statement found in item 37 of the survey form that the pastor should go to work right away and try to resolve any conflict that occurs in the church. The median score for the total sample was 1.99 indicating that the pastor "preferably should" involve himself immediately in time of conflict among groups or persons in the church. However, the officers and deacons and conference groups were less intense in their approval at 2.19 on the scale. The writer is inclined to respond with "may or may not" to this question, or at 3.00 on the scale. This may reflect his approach to the management of conflict in terms of a lose-leave attitude. ${ }^{1}$ Perhaps there are better ways. The word "negotiate" might describe one of those better ways of managing conflict in the local church.

A special question having to do with the pastor's role in time of conflict is found in part II, number 75 . It states that in helping to resolve conflict among church members and groups in the church the pastor should, according to answer A, try to reach

${ }^{1}$ See chapter IV, $\mathrm{p}$. 30, concerning the results of the writer's conflict management survey. 
a compromise solution by acting as an impartial mediator or, answer $B$, take a clearly stated position in the conflict and maintain it. Table 24 gives a complete record of the number and responses of the groups and Chi-square tests of the seven pairs of subgroups.

The response of the role set being surveyed indicates that all groups favored the A response. The role of the pastor in this case would be as an impartial mediator rather than as a judge. It is to be noted, however, that nearly 30 percent of the respondents favor the judgmental role of the pastor in time of conflict. According to this the pastor takes a firm stand in the conflict and maintains his position.

Again the writer would oppose taking a firm stand in a conflict situation, generally. However, there might be times when such a position would be necessary. Much depends upon the nature of the conflict itself. If a moral or spiritual principle would be sacrificed because the pastor refused to take a firm position in time of conflict, then by all means he should do so. A pastor cannot avoid being cast, at times, into the position of a judge. He cannot always remain neutral. Much improvement may be made in the unity of the church by negotiating conflict rather than by simply avoiding it, denying its existence, or losing and leaving it. The negotiating skills of the pastor will be taxed and utilized to advantage in conflict situations in the local church. This appears to be the preferred stance for the pastor by the respondents as well. 
TABLE 24.--Number and percentage of responses by congregation and ministers concerning conflict situations of the pastor of the Grand Rapids Central SDA church in reply to the statement: How may the pastor best help resolve conflict between church members and groups in the church?

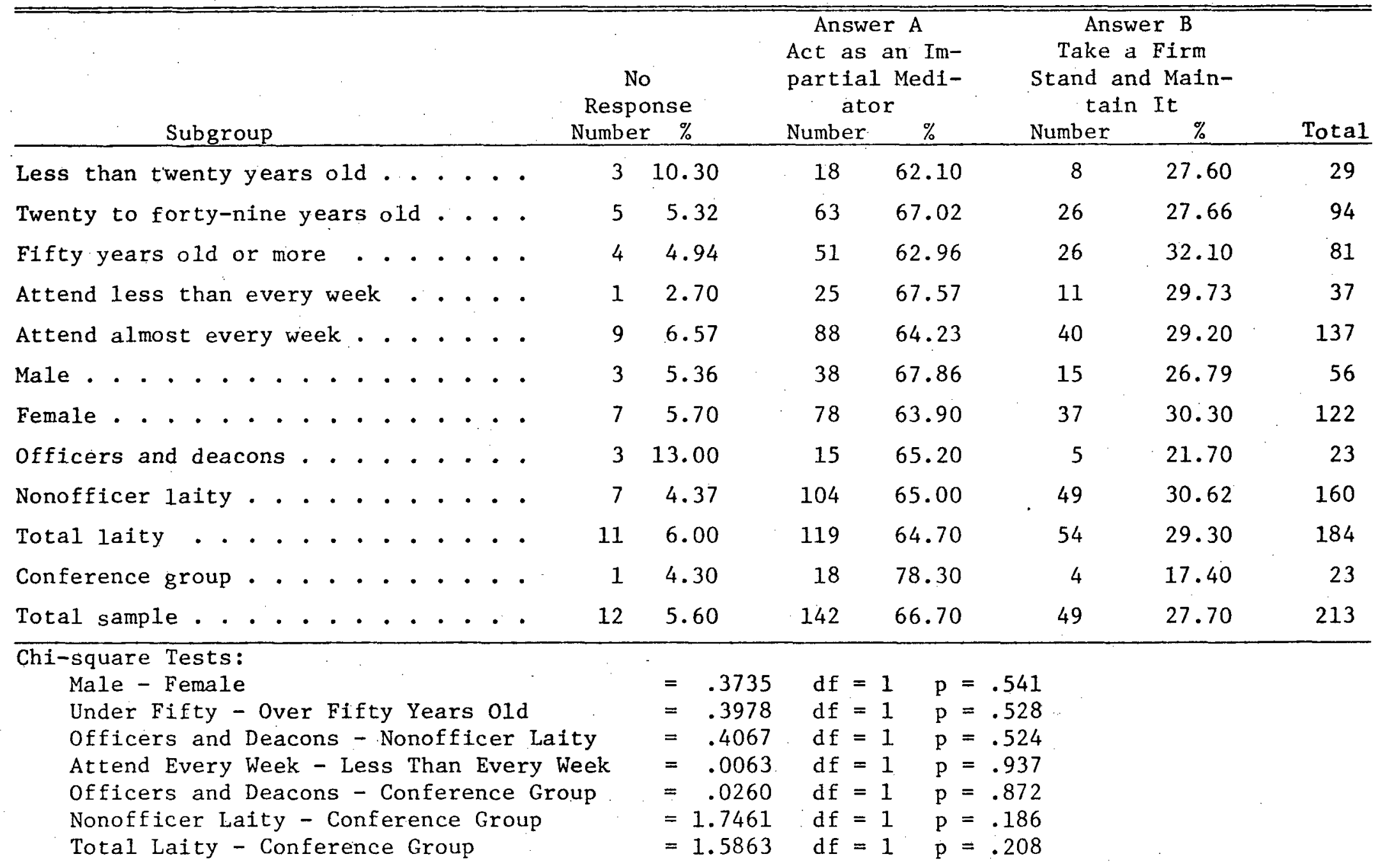


The Pastor's Visitation Program

The focal congregation in this survey has a considerable number of shut-ins and elderly. There are also a number of inactive members on the church membership list. Some attempts have been made to develop a visitation program for shut-ins and careless nembers by volunteer 1aity. Such a program was initiated during the writer's time as pastor. That this was looked upon with favor is reflected in the comments of one respondent who wrote,

I feel if as much or even half as much time and effort was spent to visit and win back discouraged members as is spent trying to win even one new member it would be great. The visitation program has been a progressive and positive innovation, also the fellowship potlucks. Our church is much friendlier now. 1

A question facing the focal pastor of this study is how often is he expected to visit the shut-ins himself. Item 38 on the survey form states that the pastor should visit the shut-ins at least once per month. The responses indicate a slight balance on the positive side of the five-point scale towards "preferably should" at a 2.44 score for the total sample. However, while the laymen were inclined more to a "preferably should" response, the conference group were more inclined to a "may or may not" response at a 2.82 score. Perhaps the ministers in the conference group are more aware of the heavy demands such a plan in a church with as many members as the one in this study would make on the time of

$1_{\text {See exhibit B, number } 201 .}$ 
the pastor. Again assistance from capable laypersons may relieve the focal pastor in this important work.

How much time should the focal pastor spend visiting the careless members and interested nonmembers? Item 39 states that the pastor should spend most of his time engaged in this work. Certainly there is a demand for it. One respondent who openly admitted not attending the church services seemed to feel that the writer had neglected him. He stated: "I have not been going to church for two years and have yet to have the pastor call at my home or on the phone to find out why. . . I would like to ask if a pastor can visit with a person who is backsliding." 1

The above statement was supported by another respondent who stated: "Before seeking to find new members, the pastor should look in his own congregation for those that haven't been to church periodically." 2

Surprisingly, in spite of the above observations by certain respondents, the general response indicates that the majority opposes the pastor spending most of his time visiting careless members and nonmembers. The total sample scored 3.22 on the one-to-five scale inclined slightly to a "preferably should not" response. The officers and deacons were even more strongly opposed at 3.59 on the scale.

There appears to be some inconsistency between the responses to item 39 and those concerning evangelism and outreach in section III of the survey form. While the respondents are wholly in favor

${ }^{1}$ See exhibit B, number 61. 2Ibid., number 52. 
of the pastor engaging in evangelistic activity, they are unwilling to have the pastor spend most of his time in such activity, according to the responses to item 39. Here is clearly an area for negotiation on the part of the pastor of the focal church.

Perhaps the respondents, the officers and deacons especially, are saying that all members should receive equal attention by the pastor. This is indicated by one respondent's personal comment that "when a new minister comes and says he will visit all homes and doesn't he had better not have said it. I know he is busy but people remember what he said." ${ }^{1}$ The writer made such a promise when he first arrived as pastor of the church in this study. The plan was for the pastor to visit in every home at least once during his stay there. The assistant pastor joined in the plan and the membership was divided between the two pastors. Every home was visited but not by the senior pastor. Unfortunately some members do not look upon the assistant pastor's visit as on the same level as a visit from the senior pastor.

How often do the respondents feel the senior pastor should visit in the homes of his parishioners? This was the concern of item 40 of the survey form. It states that the pastor should visit the home when every member is present at least once every two years. A strong "preferably should" response at 2.07 on the scale indicates this is very acceptable by the responding laity, ministers, and conference officials.

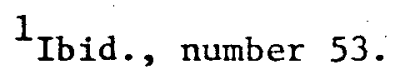


However, a larger-than-expected group of the under-fifty age group were inclined to check the "may or may not" response to item 40 of the questionnaire. Also, as might be expected, those who attend less than every week tended to be more intensely in favor of this plan at a 1.67 median score. This is a good cue for the pastor that those who attend irregularly may have needs that a visit from the pastor could help resolve.

Should the pastor always pray when visiting his members? The total sample was highly unified between an "absolutely must" and a "preferably should" response at 1.64 on the scale for item 41 of the survey. The pastor can be assured that he may pray if he should so desire with practically any of his parishioners in the church of this study. The younger respondents appear to be slightly less favorable than the older age groups. Apparently the prayers of the pastor are significant to the respondents of this study.

Counseling and Referral Expectations

for the Focal Pastor

Many who come to the pastor for personal counseling are women. Among these women are some who are experiencing marital difficulties. Question 42 of the survey form was included to test the respondents as to their approval of the pastor being free to engage in counseling the opposite sex, especially those experiencing marital problems.

The respondents were almost evenly divided on the matter at a 2.99 point on the scale. As might be expected the over-fifty age group were more opposed, whereas the younger groups were more 
In favor. However, the conference group were more strongly opposed to the pastor performing such a ministry for the opposite sex. It appears that the conference group and many others of the respondents do not consider the counseling ministry of the pastor as part of his professional role.

If the pastor should not counsel with those of the opposite sex who are having marital difficulty then should he make distinctions between persons who come to him for guidance? This is the issue involved in item 43 of the survey form. It states that the pastor should be willing to counsel any and all who come to him for help.

The response was a strong 1.79 score between "preferably should" and "absolutely must" on the one-to-five scale. One respondent, a conference employee, stated: "I believe the pastor should pastor all members." 1

The conference group was consistent with its answer to the previous question by approaching a "may or may not" response to item 43 of the survey form at a 2.42 median point of the scale. Evidently there are some differences of opinion existing among the conference group concerning the counseling ministry of the pastor. There seems to be less confusion among the laity as to whether pastoral counseling is a part of the pastor's professional role in the local church than among the ministers and conference officials.

The writer is inclined to agree with the laymen more than with his ministerial colleagues on the above issue. Of course much

\footnotetext{
${ }^{1}$ See exhibit $B$, number 21 .
} 
depends upon the pastor as to how much counseling he does and with whom. A bit of professionalism seems necessary for the pastor as with others who must minister to those who have personal problems. To attain a professional stance may require additional training on the part of the pastor himself. Otherwise, perhaps he should avoid certain situations in which he may be involved with the opposite sex.

The final item of section IV concerns the pastor referring to the professional counseling services all those who come to him with difficulties. Of course this would be an easy way to reduce the amount of time and work involved with these people. How do the respondents feel about such a plan on the part of their pastor?

Responses from item 44 of the survey reveal that the pastor "preferably should not" at 3.72. This supports what psychotherapists have known for some time, that pastors are favored as counselors by the majority of people who are in trouble. One writer states, "A joint commission survey of national mental health resources revealed that when people felt emotionally distressed they preferably turned first to a clergyman." ${ }^{1}$ The reasons given include the following:

There are many more clergymen, they are widely scattered and geographically accessible, they are easy to contact at any time, they are less expensive, their role and function are usually well known so that people know what to expect, and they have ongoing contacts already established with many people, so that in time of crisis it is natural to turn to them. 2

\footnotetext{
$1_{E}$. Mansell Pattison, ed., Clinical Psychiatry and Religion (Boston: Little, Brown and Company, 1969), p. 246.

2 Ibid.
} 
The respondents in the survey of this study seem to agree with the above observation. The writer has found that his parishioners will usually come to him first if he reveals a desire to be of help, shows some professionalism in connection with his pastoral work, and reflects dedication and devotion to the high standards of the Lord Jesus Christ.

Summary of Analysis of Responses Concerning Pastoral Counseling and Visitation

This section has revealed certain attitudes and preferences for the focal pastor of this study concerning his counseling and visitation program. To summarize the following insights stand out:

There is obvious confict among the respondents as to whether the focal pastor should use psychologic principles along with spiritual resources in his pastoral work. The majority seem to prefer that the pastor utilize only spiritual resources.

In times of conflict it appears the respondents prefer the pastor to act more in the role of a mediator rather than as a judge or as an unyielding authority.

There was some opposition from the respondents to the pastor spending most of his time visiting careless members and nonmembers in an effort to win them back to the church. An inconsistency appears to exist between the respondents desire for evange1istic outreach and their desire to restrict the pastor's activity from outreach for the careless members and nonmembers.

A serious division among the respondents appeared in connection with the pastor counseling with persons of the opposite 
sex who have marital problems. Referral to professionals in the city appears to be an undesirable alternative to limiting the pastor's availability to those needing his assistance.

From these insights there is some indication that a sizeable group of the respondents have yet to view pastoral counseling as a professional function of their pastor. Considerable negotiation will be necessary to help the entire role set to understand this aspect of the pastor's work.

Much that the pastor communicates is about himself. His life-style, approach to his work, and personal relationships all speak for or against his ministry. What do the subgroups surveyed expect of the pastor concerning these matters? Section $V$ seeks to obtain an answer to this question.

\section{Section V--Analysis of Responses Concerning Personal and Family Expectations}

A considerable literature has developed in recent decades to inform the laymen of the Christian community about their pastor's problems. The title usually indicates the nature of the material presented.

To name a few, William $E$. Hulme published a guide for ministers and laymen entitled, Your Pastor's Problems. ${ }^{1}$ Ralph G. Turnbull's, A Minister's Obstacles, is concerned with "the wrestlings and intricacies of the heart. It is in the inner realm of the

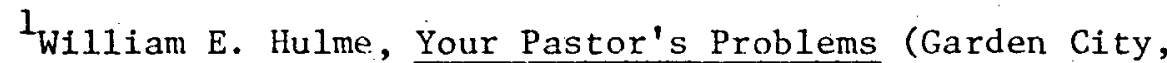
New York: Doubleday and Company, 1966). 
preacher's life that a man is made or unmade."1 Daniel D. Walker's concern is expressed in The Human Problems of the Ministers. "It is with human tensions, as they appear in the clergy, that this material deals." ${ }^{2}$ Finally, Lucille Lavender, a minister's wife, has recently produced the book They Cry Too! According to Lavender, her purpose is to share with laymen "what you always wanted to know about your minister but didn't know whom to ask. The book is addressed to a problem common to most clergymen--being accepted as a human being!" ${ }^{3}$ These and other books and articles like them attempt to relate the pastor's position, his person, and his roles to the modern situation.

The local SDA pastor is no less faced with updating his ministry. Besides the current literature, he has the added source of counsel, the writings of Ellen G. White, to provide him with a wealth of guidance concerning the pastoral ministry. Whether this makes the role of the SDA pastor more clear or not depends much upon the pastor himself and how he relates to his work. As one reads the counsel from the writings of Ellen G. White, he is struck with the deeply spiritual emphasis when the author discusses the life and work of the pastor.

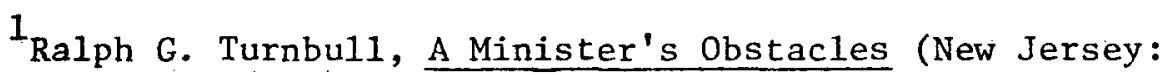
Fleming H. Revel Company, 1966), p. 5.

2 Daniel D. Walker, The Human Problems of the Minister (New York: Harper and Brothers, 1960), p. xi.

${ }^{3}$ Lucille Lavender, They Cry Too! (New York: W. Clement Stone Publisher, 1976), jacket blurb. 
One reference states that "the minister of Christ must possess an undying love for souls, a spirit of self-denial and of self-sacrifice." ${ }^{1}$ Another states:

Positions have no power to develop a man's character. It rests wholly with the man himself to prove whether he will work himself, which means that Satan will work him, or whether he will be worked by the Holy Spirit. 2

The minister as a person, therefore, is to represent the "crucified life" experience or as "the sacramental person . . one through whom is experienced the person of the church and of Christ." ${ }^{3}$ As has every true Christian, so has the pastor "experienced the death of the ego--the surrender of all natural securities and even the sense of self, in order to enter the kingdom of God. . . . ${ }^{4}$

The rash of literature concerning the person of the pastor that has been produced in recent years indicates a concern for his welfare in his high and holy calling. It seems to be a concern that the pastor's position be made relevant to modern times and yet retain its hallowed tradition.

One writer has stated that "the clergy are a lonely, set apart people." ${ }^{5}$ So also is being captain of a ship a lonely

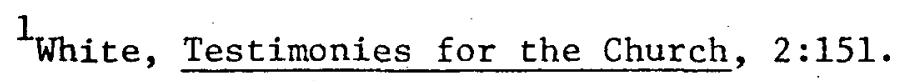

Ellen G. White, Testimonies for Ministers (Mountain View, Calif.: Pacific Press Publishing Assoc., 1944), p. 288.

${ }^{3}$ Urban T. Holmes, III, The Future Shape of Ministry (New York: The Seabury Press, 1971), pp. 92, 93.

4 Biersdorf, Creating an Intentional Ministry, p. 29.

${ }^{5}$ Margaretta K. Bowers, M.D., Conflicts of the Clergy: A Psychodynamic Study with Case Histories (New York: Thomas Nelson and Sons, 1963), p. 7. 
position. This writer, however, who is a psychiatrist, has great concern for the clergyman. Some human understanding seems in order.

And they are told they should pray and everything will be al1 right. But how can a man pray when his ship is in such desperate plight?. . . It seems to me that the very least we can do for these men is to give them the mental and psychological health, the emotional health and maturity so that they are not weak, scurvy-ridden ships. ${ }^{1}$

How do SDA laymen see their pastor? How competent should he be to satisfy their needs? How human may he be in his life style? What is expected of his wife and children? To what spiritual level must the focal pastor of this study be to meet the expectations of his role set? It is to these and other similar questions that the following analysis is directed.

An Analysis Concerning the Motivating Call of the Focal Pastor to the Ministry

What motivates men to become ministers? The motives may be as varied as those which prompt people to become members of the church. However, certain motivating factors seem more acceptable than others when it comes to accepting a call to the ministry.

Item 73 on the survey form states that the pastor should, according to answer A, be motivated by a thorough conversion through which he felt a deep call of God into the ministry or, answer $B$, by a desire to help people find the better life and help solve social problems within the Christian context. In other words answer A is. the God-centered call motive and answer B the human-centered motive.

\section{${ }^{1}$ Ibid.}


Table 25 provides a complete breakdown of the number of responses, percentages, and Chi-square tests concerning motivations for the ministerial call.

The responses of the total sample indicate that the great majority favor the God-centered call, or answer A. There were 74.6 percent of the total respondents in favor of answer A. However, not every subgroup was in favor of this response.

The less-than-twenty-year-old group was in direct opposition to all other groups with only 37.9 percent in favor of answer $A$ and 55.2 percent in favor of answer B, the humancentered call to the ministry. Apparently the youth see the pastor in a different light so far as his motivating call to the ministry is concerned.

The strong response in favor of the spiritual call indicates that the majority favor a pastor who works under the arched dome of a mystical call of God supported by a thorough conversion experience. However, it is significant that 19.2 percent of the respondents favor a minister that works under the burden for the welfare of his fellowmen.

Two approaches to the ministry are seen here, both of which are valid motivations for ministry. They are not mutually exclusive but some elements of both may be necessary. for a successful ministry. The strong favor to the spiritual call is consistent with the respondents position with reference to the pastor utilizing only spiritual resources rather than a combination of spiritual and psychological resources in his counseling ministry. 
TABLE 25.--Number and percentage of responses by congregation and ministers concerning the motivating call to the ministry of the pastor of the Grand Rapids Central SDA church in reply to the statement: What should be the pastor's dominant motivation for ministry?

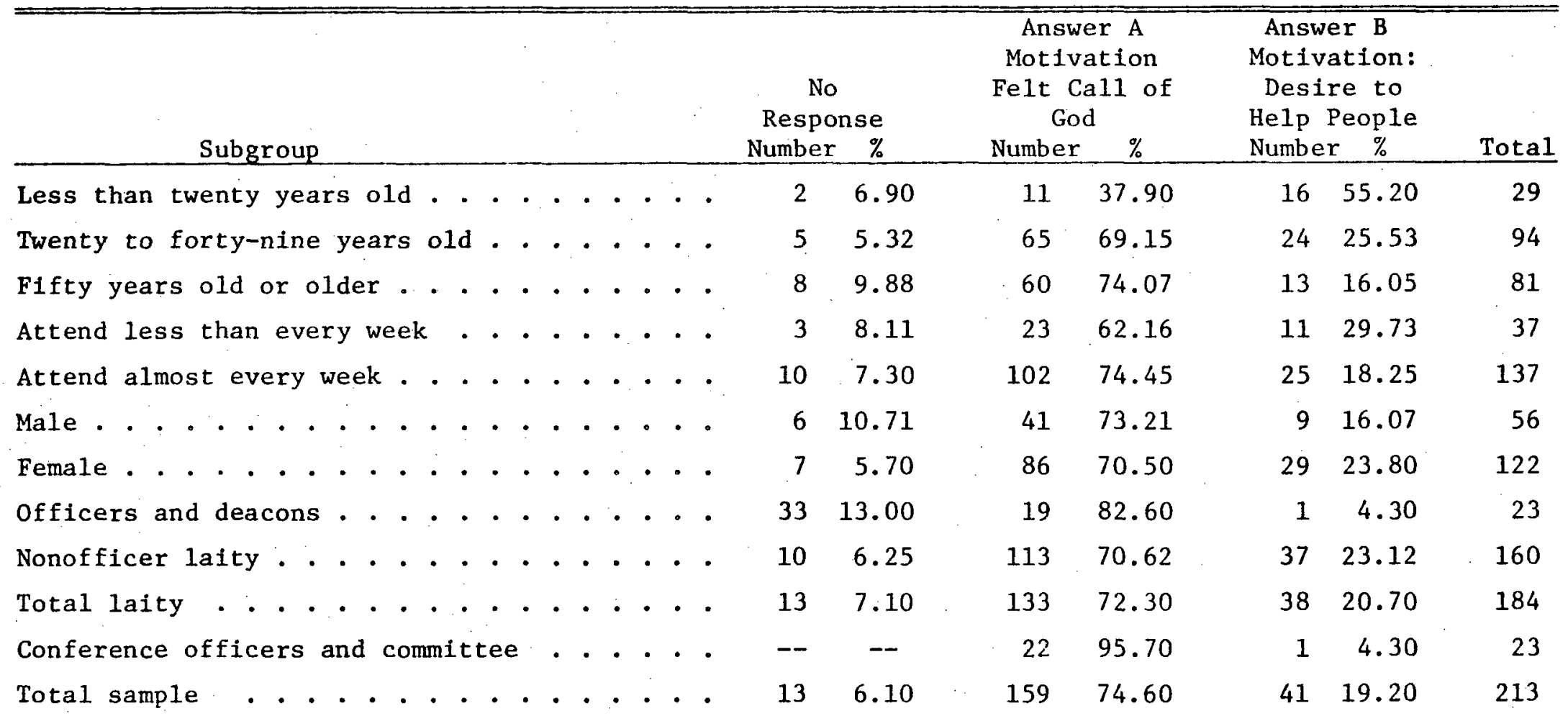

\begin{tabular}{lllll}
\hline Chi-square tests: & $=.9611$ & $\mathrm{df}=1$ & $\mathrm{p}=.327$ \\
Male - Female & $=1.9086$ & $\mathrm{df}=1$ & $\mathrm{p}=.167$ \\
Under Fifty - Over Fifty Years 01d & $=3.1495$ & $\mathrm{df}=1$ & $\mathrm{p}=.076$ \\
Officers and Deacons - Nonofficers & $=2.4792$ & $\mathrm{df}=1$ & $\mathrm{p}=.115$ \\
Attend Almost Every Week - Less Than & $=.0043$ & $\mathrm{df}=1$ & $\mathrm{p}=.947$ \\
Officers and Deacons - Confernce & $=4.8034$ & $\mathrm{df}=1$ & $\mathrm{p}=.028$ \\
Nonofficers - Conference & $=2.9966$ & $\mathrm{df}=1$ & $\mathrm{p}=.083$ \\
Total Laity - Conference & & &
\end{tabular}


The strong spiritual emphasis reveals an aversion to anything that savors of a humanistic, social-gospel approach to the ministry. It reflects a Bible-centeredness, spiritual approach to life. On the other hand, the small group who chose answer B reflect a desire to see a more human-centered ministry on the part of the pastor. He is, therefore, to be more involved in the human dilemma than in only heavenly issues.

Expectations Concerning the Pastor's Devotional Life

The importance of the pastor taking time to engage in prayer and personal devotions is the subject matter of item 45 on the survey form. This would seem to be an almost obvious activity for the pastor. However, the writer has observed by experience that it is difficult to maintain a consistent devotional and prayer life as a pastor. Median responses for the various groups on this and other items in this section are found in table 26.

Does the response from the survey indicate support for the pastor to maintain a devotional life? The answer is an overwhelming yes, at a 1.44 score, between "absolutely must" and "preferab1y should" on the scale. The conference committee and ministers were even more insistent at 1.02 on the one-to-five scale. The pastor also has the added encouragement to "guard jealously your hours for prayer and self-examination. Set apart some portion of each day. for a study of the Scriptures and communion with God."I

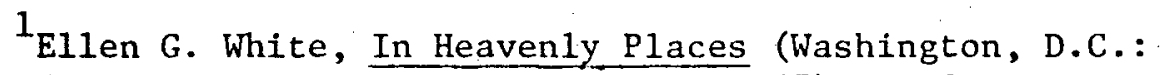
Review and Herald Publishing Association, 1967), p. 85. 
TABLE 26.--Median responses of the congregation, conference committee, and certain ministers concerning personal and family expectations of the Grand Rapids Central SDA pastor

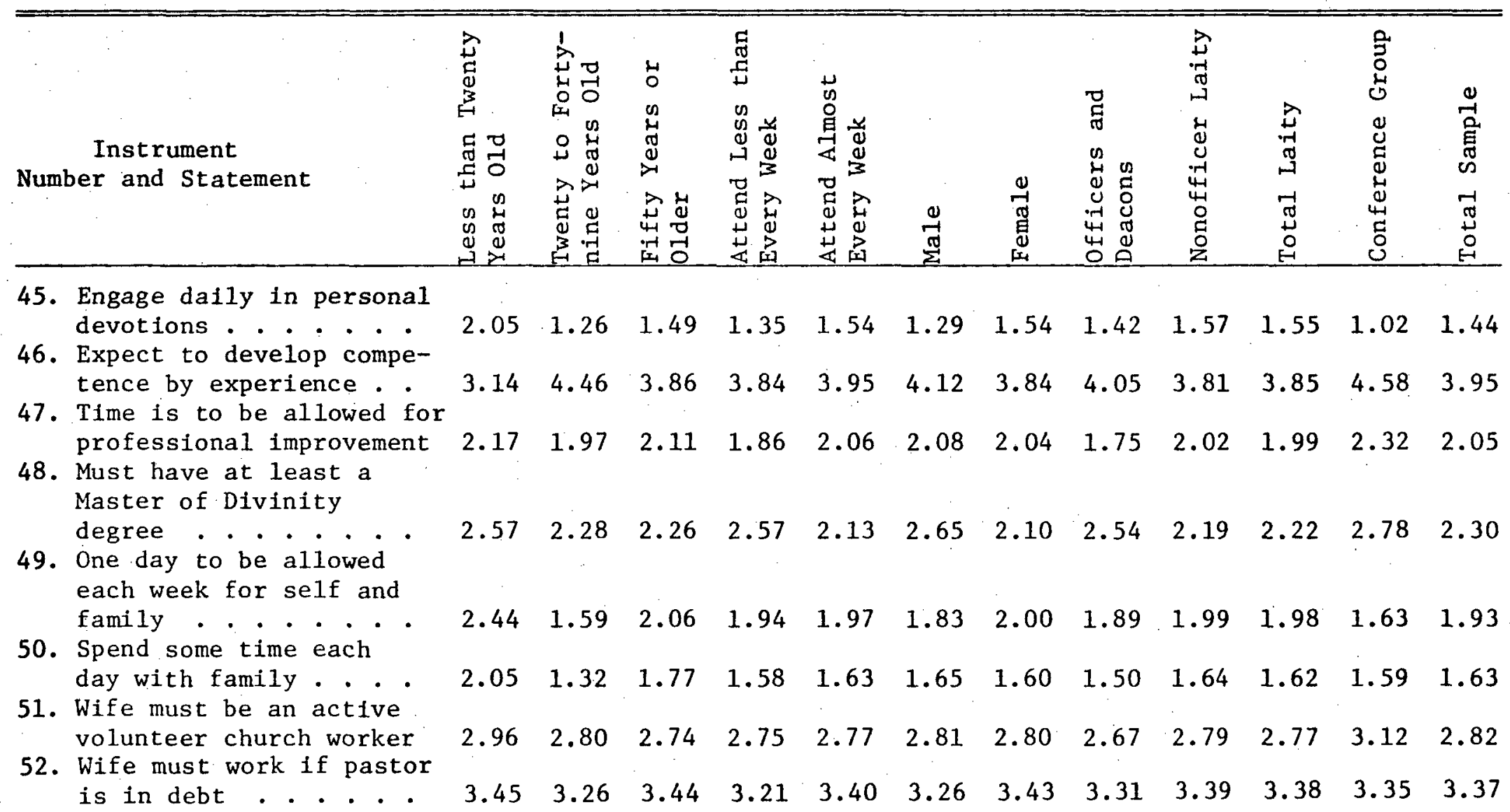


TABLE 26 (Continued)

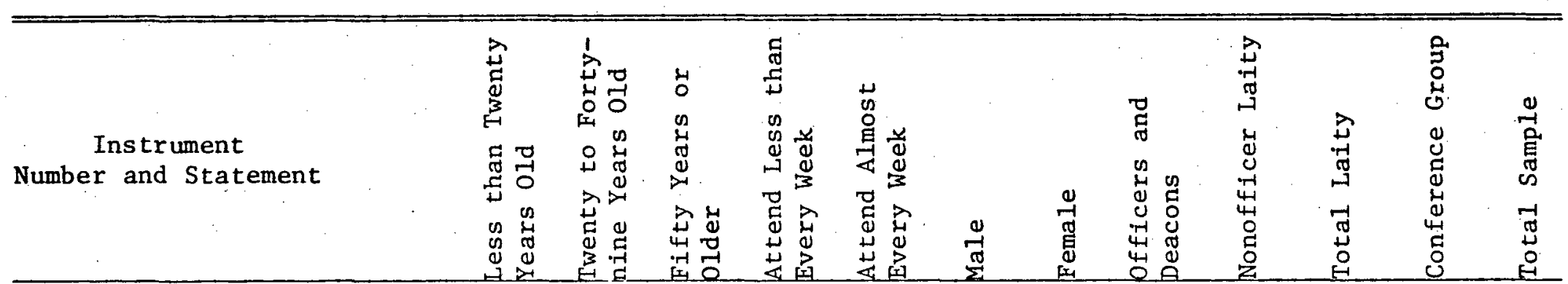

53. Avold close friendships with church

parishioners . . . . $\quad . \quad \begin{array}{lllllllllllll}3.79 & 3.84 & 3.66 & 3.74 & 3.79 & 3.79 & 3.71 & 3.67 & 3.81 & 3.79 & 3.68 & 3.76\end{array}$

54. Cultivate close friend-

ships with those out-

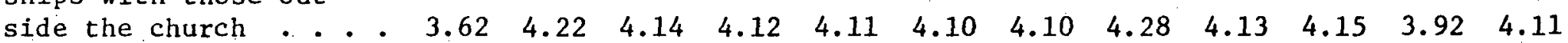

55. Children of pastor must

be good examples . . . . $\begin{array}{lllllllllllll}2.08 & 2.03 & 1.94 & 1.79 & 2.01 & 1.93 & 2.01 & 1.97 & 2.00 & 1.99 & 1.97 & 1.99\end{array}$

56. Be visibly present at

most church and

$\begin{array}{lllllllllllllllll}\text { social gatherings } & . & . & 2.05 & 1.95 & 1.85 & 1.86 & 1.91 & 1.97 & 1.87 & 2.12 & 1.91 & 1.90 & 2.00 & 1.92\end{array}$

Median figures are based on a range of one to five as follows: 1 - Absolutely must 2 - Preferably should 3 - May or may not 4 - Preferably should not 5 - Absolutely should not 
One respondent believes the spiritual impact of the pastor

is the most important contribution, as stated in the following:

A11 pastors have their fields of interest, their strengths and weaknesses. Congregations have the right to expect to have the individual's need of the ministry be met but the lasting impact of a minister is going to come from spiritual growth (or lack of it) of that congregation that he was able to nurture. How he is able to bring this about would be the goal.1

The respondents to this survey believe that the church's spiritual growth depends much upon the pastor's level of spiritual attainment. This supports the familiar statement that the church will seldom rise to a higher spiritual level than that maintained by the pastor. It also implies some degree of competence on the part of the pastor. How competent must he be? Ought he to improve his competency in any way? The pastor's competency is the concern of items 46,47 , and 48 of the survey form.

Responses Concerning the Competence of the Pastor

Item 46 states that the pastor should gain competence for his ministry through experimentation or through trial and error. The response was that he "preferably should not" at 3.95 on the one-to-five scale for the total sample. The conference group was even stronger, 4.58 on the scale, showing opposition to the pastor learning only by trial and error. The writer is inclined to agree with the respondents. However, while in theory the pastor should learn his work by means of observation, the example of fellow ministers, and instruction, in practice he probably learns more 
through experimentation. Of course by the time he becomes an ordained pastor he will have learned some things that need no further experimentation.

From where does competence for the ministry come? It "is the primary outcome of effective continuing education." ${ }^{1}$ This implies that he has already attained to a certain level of education and that he is to merely continue what he has already begun.

Should the focal pastor of this study be allowed to have certain free time each year to improve his professional competency? Does the congregation and conference group consider this an important part of the pastor's work life?

The responses to item 47 indicate that the majority of the respondents would approve of such a plan with a score of 2.05 on the scale. The officer and deacon group were even stronger at a 1.75 .

It appears that the respondents would favor the pastor obtaining additional education while serving as pastor of the church. This would need to be a negotiated matter between the pastor, the congregation, and the conference group.

However, not all appeared to favor such a plan, as revealed by a personal comment of one of the respondents: "I suggest that all educational goals be completed before a pastor comes to a church of the size of the Grand Rapids [church]. If more education is wished for then resign." 2

${ }^{1}$ Mark A. Rouch, Competent Ministry (Nashville: Abingdon Press, 1974), P. 10.

${ }^{2}$ See exhibit B, number 90. 
How much education should the focal pastor of this study have beforehand to meet the wishes of the responding group? Item 48 states that the pastor should at least be a graduate from the seminary with a Master of Divinity degree. The response indicates a wide difference of opinion exists among some of the subgroups. While all the groups favored the pastor having the M.Div. degree, there was a noticeable lack of positiveness for the total sample at 2.30 on the scale between "preferably' should" and "may or may not." This was especially noticeable for the conference group at 2.78 on the scale.

The tendency of the respondents toward a "may or may not" response indicates that the M.Div. degree is not considered so important as perhaps other qualifications. It may also indicate some tendency to minimize intellectualism in a pastor in favor of personality qualities. If this be so, it would not be unique since other studies detect an aversion to having an "intellectual" as pastor of a local church. ${ }^{1}$

Responses Concerning the Pastor's Wife and Family

Some of the respondents expressed their concern that the pastor have some time with his wife and family. One respondent expressed this concern in a personal observation which is quoted in full.

$1_{\text {Vidich and Bensman, quoted in Milner, Ministerial Role }}$ Expectations of Clergy, p. 14. 
Most pastors are very conscientious about their duties. We recognize that pastors are human too and must have time to rest and refresh their minds. Probably most pastors work too hard. Their families are important to us too. We are concerned for their health, their wife and children too. Speaking for one person, myself only, I definitely feel a pastor should definitely have one day off each week when he can be free to be with his family. Most would not begrudge him this. 1

The sentiment expressed above supports the responses to item 49 of the survey form. The total sample scored at 1.93 on the scale with a strong "preferably should". in response to the statement that the pastor should spend one day each week with his family. The conference group was even more insistent at 1.63 on the scale. As seen earlier the writer attempted to set aside one day each week for family activities but still averaged approximately seven hours in some type of church or conference related activity on that day. ${ }^{2}$ It is to be admitted that perhaps some of the activity was not heavy in terms of the work involved.

The respondents were even more insistent that the pastor spend some time each day with his family. An hour was suggested. This was the issue involved in item 50 of the survey form. The total sample responded at 1.63 . This supports what has already been stated above.

As important as the pastor's educational qualifications, his talents, and abilities are to him, recent studies show that the pastor's wife

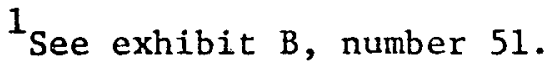

${ }^{2}$ see chapter IV, p. 11.
} 
is a major support to him. This appears to be true all throughout the career . . . family support seems especially necessary for clergy. Whatever the liabilities of a married clergy, there can be no doubt that the marital relationship is one of the strongest supports the minister has.1

What is the role of the pastor's wife? What is expected of her in the focal church of this study? Item 51 on the survey form states that the pastor should expect his wife to be available at all times for volunteer church work such as community services, friendship visitation, and being helpful where needed.

The response to the above statement was only slightly in favor of the pastor's wife fulfilling the above described role. The total sample scored at a 2.28 median value, near to a "may or may not" response. A considerable number, apparently, while favoring the pastor's wife being available would prefer leaving it open to the pastor and his wife.

A striking difference appears between the conference group at 3.12 on the scale and the laity group at 2.77 on the scale. Apparently the conference group see this as optional and oppose making such demands upon the pastor's wife unless she herself wishes to fill such a role. With the changing role of women in general, it appears that the pastor's wife can no longer be expected to function as a "free" servant of the local church or conference. Many have personal skills that are in demand on the labor market which provides the pastor and his family with additional income. Should the pastor's wife be employed outside the home? Item 52 of the survey deals with that question. 
Item 52 states that the pastor's wife should work away from home when extra money is needed because of indebtedness. The general response to this reveals definite opposition exists among the respondents to the pastor's wife working outside the home. This is Indicated by the 3.76 score on the one-to-five scale. Also there was considerable unity on this point. Apparently, however, a number of the respondents would prefer this to be an optional duty for the pastor's wife as well. The writer's wife has not worked on a full-time basis during the time he served as pastor of local SDA churches. This was mainly because small children were in the home and she desired to be a fulltime mother to them. Each pastor's needs are different from another's. While the respondents seem inclined to prefer the pastor's wife to be involved wholly in the life of the church, they are also willing for it to be negotiated.

More pointed responses were provided by three of the respondents concerning the role of the wife of the pastor. One states, "I feel the pastor's wife should not work unless absolutely necessary, and be available when needed. She should also be present at bridal and baby showers, [and] 'women's' gatherings." 1 Another respondent tends more to leave the decision up to the pastor and his wife by stating:

As far as the pastor's wife working, I feel it should only be between them. If the church is not paying for the services of the wife, how can they expect her not to work. After all, only the pastor was hired, not his wife. 2 
A third respondent was opposed to the pastor's wife working but offered a simple solution by stating, "The minister's family should not allow themselves to be in debt. It is not a good example to the church family." 1

From the survey response and the personal comments it appears that considerable division exists among the subgroups surveyed as to the role of the pastor's wife. Today a large number of women work outside the home to enhance the family income. It is not surprising that the pastor's wife also works outside the home and the church to enhance the family income. This may provide a very important issue for the pastor to negotiate with his congregation and conference.

\section{Responses to Expectations Concerning} the Pastor's Social Life

The writer has overheard young pastors say that they have been advised not to develop close friendships with the members of their congregations. In fact, the writer himself took such a position early in his ministry. The apparent concern is that as head of the local congregation he must avoid any appearance of being partial to a certain few. The pastor's concept of his position and his style of leadership may influence his social relationships with his members. If he sees himself as a chief minister and the laymen as helpers, he then may be unable to develop close friendships in the congregation. His position may

\footnotetext{
${ }^{1}$ Ib1d., number 153 .
} 
thus become a barrier between himself and his members. On the other hand if he sees himself more as a minister among other ministers in the congregation he may be able to develop a very close friendship with many of his parishioners. 1 Two items on the questionnaire were devoted to the pastor's relationships within his congregation. These were numbers 53 and 54 .

Item 53 states that the pastor should keep a professional distance between himself and church members and avoid close friendships with anyone in the church. The respondents strongly oppose such a position on the part of the pastor with a median response of 3.76 or close to a "preferably should not" response. There appears to be little variation among the eleven subgroups in their response to this question. The respondents generally would like to be close friends with the pastor and his family, according to the survey. This portends well for a negotiated ministry of the type suggested by this study.

The response to item 54 stating that the pastor should form most of his close friendships outside the church received opposition. At 4.11 on the scale the respondents firmly oppose such a friendship plan for their pastor. A high degree of unity is reflected among the subgroups on this question.

Possibly most respondents feel the pastor has enough to do just to learn the names of everyone in the church. This is clearly stated by one respondent. "When a new minister comes

${ }^{1}$ See chapter V, p. 135 concerning analysis of item 77 . 
[he should] try to ask everyone their name, and show an interest in everyone, not just the ones who are the officers in the church." 1 The writer is inclined to agree with the respondents as far as close friendships between himself and his members is concerned. To provide the pastor with human association, unless he develops some friendships within the church, to whom should he go? It is the writer's conviction that not only will the pastor benefit by such friendship but the church itself will become more friendly to those who come under its influence.

The pastor's children have often been a source of difficulty for the pastor and, at times, the church as well. How normal may the pastor's children be? Should they be expected to represent the position of the pastor in their relationships with their peers?

The very simple statement found in item 55 of the survey, that the pastor's children should be good examples to other children, met with a "preferably should" response at 1.99 on the scale. The over-fifty age group tend to be even more insistent than the under-fifty age group. However, little variation is observed among the subgroups.

Concerning the pastor's children one respondent stated, "Expectations for children are often unfair pressures. Let's give our pastors sufficient opportunity to be parents as well, and more of their children will be the children God desires." ${ }^{2}$ A

\footnotetext{
${ }^{1}$ See exhibit $B$, number 53. $\quad{ }^{2}$ See exhibit $B$, number 145 .
} 
pastor's child does have some advantages and privileges that many other children do not have. Among these are the constant exposure to the best literature and music, the finest people, the highest ideals of Christian living and a wider perspective of life than children of many other professionals.

The pastor's visible presence at a church meeting or social occasion is often seen as important to its success. Item 56 states that the pastor ought to be visible at religious and social occasions of the church. It was met with a "preferably should" at 1.92 on the one-to-five scale by the total sample. However, there was less intensity on the part of the officers and deacons and conference group. Most ministers are aware that it is not possible to attend every social or religious occasion conducted by the various organizations within the church. Perhaps this explains why leaders would not be so insistent that the pastor commit himself to being present for every occasion.

\section{Summary of the Responses Concerning}

Personal and Family Expectations for the Focal Pastor

Section $V$ touched on some of the expectations and attitudes of the respondents of the survey towards the pastor's personal, family, and social life. Four points stand out.

1. The respondents prefer that the pastor be motivated for his ministry by a spiritual call from God rather than his burden for the human dilemma only. They urge the pastor to maintain a high level devotional life. 
2. While there was not full agreement, it was generally admitted that the pastor should be allowed to continue his education while serving as pastor of the focal church.

3. The respondents were balanced slightly in favor of the pastor's wife being available for voluntary service and also that she ought not to work away from home.

4. The pastor and his family are expected to make their friendships within the church and be visible at the church and social occasions as much as possible.

There appears to be a sincere desire on the part of those responding to the survey to identify with the pastor in his multirole expectations so that he may have time for himself and his family. It appears that the respondents would willingly negotiate with the pastor to make this possible.

One very visible function of the pastor is the conducting of the religious services of the church. A discussion of the responses concerning this aspect of the pastor's work is presented in the next section of this chapter.

\section{Section VI--Analysis of Responses \\ Concerning Preaching and Worship}

Seventh-day Adventists have the distinction of worshiping on Saturday on what they believe to be the Bible Sabbath. They have a strong conviction that they are keeping the day sanctified by God and are aware of the social stigma attached to keeping a different day of the week as a day of rest. For this reason the weekly worship experience may have special significance to the 
Seventh-day Adventist church members. To them God has called the service of worship on His special day (Is $58: 13,14$ ). The SDA worshiper responds with the specific object in view of attending the house of worship and offering praise and thanksgiving to God along with his tithes and offerings. Objectively he should be fulfilling the expectation of God. Subjectively he should receive encouragement, comfort, and spiritual help to face the issues of daily life.

Apart from the keeping of a different day, however, Seventh-day Adventists have departed little in the way they conduct their worship services from other fundamental Christian groups. The sermon is given the dominant place in the order of service along with congregational singing, public prayer, gifts and offerings, and special musical presentations. There is a noticeable absence of a formal 1iturgy. Many SDA pastors create their own order of service that appears to meet the demands of the local situation.

Who presents the sermon? The pastor is to be more than an administrator, a promoter of the denominational program, the maintainer of a good community image, a counselor, a visitor, husband, and father. He is to proclaim and preach the message of salvation. Of course, no one expects the pastor to do all these equally we11. But he is expected to be a good speaker or "talker."1

$1_{\text {Robert }}$. Lynd and Helen Merrell Lynd, Middletown (New York: Harcourt, Brace, and World, 1929), p. 344. 
The Bible says, "Jesus came preaching" (Lk 8:1). As undershepherds of Jesus Christ, every pastor is to preach (2 Ti 4:2). It is not only his privilege, it is his responsibility. Perhaps there is no activity in which the pastor functions that makes him more visible than in his conducting of the Sabbath worship services. The majority of the members attend this service. and it recurs every week. It is not surprising, therefore, that laymen are more discerning of the pastor's strengths and weaknesses in this area of his work than in any other in which he engages. In the work life of many a pastor, the preaching function may absorb but a small portion of his time and energies. His Sabbath sermon may be but the tip of the iceberg of his total work 1ife. This is not to deny the importance of the function. The writer is impressed that the level of the pastor's speaking ability and persuasive powers determines in the minds of most church goers the degree of his success as a minister. Is this supported by the respondents surveyed in this study? The answer will be found at least partially in the analysis of the responses concerning the preaching and worship issues that follow.

Two major services are discussed in this section that involve the pastor in preaching and worship activity. Items 57 , 60-63 are mainly concerned with the Sabbath worship service; items 58 and 59 with the midweek prayer service. Table 27 gives a picture of the median point on the five-point scale for the responses of the various subgroups as well as the total sample. 
TABLE 27.--Median responses of the congregation, conference committee, and certain ministers concerning preaching and worship expectations of the Grand Rapids Central SDA pastor

\begin{tabular}{|c|c|c|c|c|c|c|c|c|c|c|c|c|}
\hline $\begin{array}{l}\text { Instrument } \\
\text { Number and Statement }\end{array}$ & 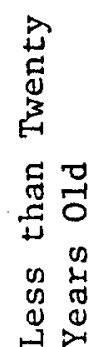 & 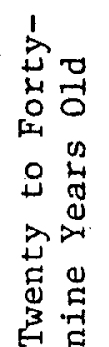 & 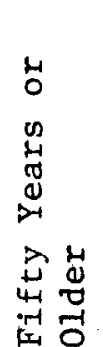 & 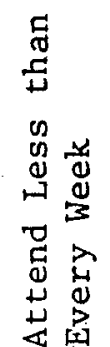 & 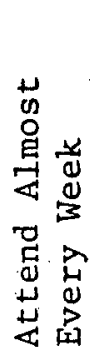 & 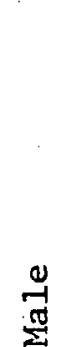 & 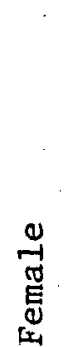 & 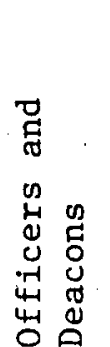 & 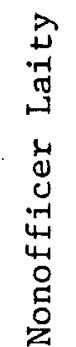 & 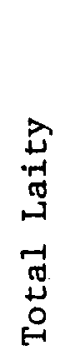 & 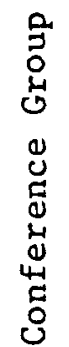 & 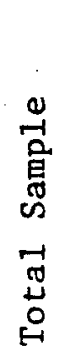 \\
\hline
\end{tabular}

57. Preach in the church at least three times a month . . . . . . .

58. Conduct mid-week services without fail.

59. Involve others in conducting mid-week services . . . . . .

60. Spend more time in sermon preparation than any other . . . . .

61. New worship innovations are encouraged ....

62. Must a sermon always be presented? . . . . .

63. Let the sermon serve for discussion groups.

$\begin{array}{lllllllllllll}2.17 & 2.11 & 1.88 & 2.19 & 1.94 & 2.06 & 1.96 & 1.97 & 1.99 & 1.98 & 2.04 & 1.99 \\ 2.39 & 2.45 & 2.09 & 2.27 & 2.24 & 2.23 & 2.27 & 2.12 & 2.28 & 2.25 & 2.18 & 2.25 \\ 2.06 & 2.35 & 2.26 & 2.18 & 2.24 & 2.50 & 2.13 & 2.42 & 2.17 & 2.20 & 2.45 & 2.24 \\ 3.04 & 3.05 & 2.57 & 2.68 & 2.88 & 2.94 & 2.82 & 3.15 & 2.80 & 2.85 & 2.96 & 2.86 \\ 2.75 & 3.21 & 3.07 & 2.78 & 3.16 & 3.10 & 3.05 & 3.06 & 3.11 & 3.10 & 3.00 & 3.07 \\ 2.73 & 2.87 & 2.98 & 2.63 & 2.98 & 2.81 & 2.96 & 2.92 & 2.94 & 2.94 & 2.69 & 2.92 \\ 2.75 & 2.89 & 3.06 & 2.66 & 3.00 & 2.95 & 2.95 & 3.06 & 2.96 & 2.97 & 3.02 & 2.97\end{array}$

Median figures are based on a range of one to five as follows: 1 - Absolutely must 2 - Preferably should 3-May or may not 4-Preferably should not 5 - Absolutely should not 
The reader is directed to Table 27 for each of the items discussed in this section.

Analysis of Responses Concerning the Sermon and Sabbath Worship Service

Pastors may vary in their desire to preach. The writer is inclined to believe that most pastors enjoy this part of their work. In fact, they may be reluctant to allow others to fill their pulpits.

The frequency of the pastor's preaching appointments is the topic of consideration in item 57 of the survey. It states that the focal pastor should conduct the Sabbath worship services and speak at least three or more Sabbaths per month. Does this proposal appeal to the respondents? Apparently it does. A fairly strong positive response at 1.99 is observed for the total sample. A high degree of unity in the response indicates this to be an acceptable plan for the pastor of the focal church in this study. However, there remains at least one and occasionally two Sabbaths per month when additional speakers are needed.

Who, then, should be asked to speak when the pastor does not? One respondent suggested, "I would like to hear occasional sermons from qualified lay members if possible." 1 Possibly this would be a good plan. However, the writer has found that it is not difficult to obtain someone to speak in the church of this study. In fact, there are often not enough Sabbaths to accommodate all of those who wish to be scheduled. The assistant pastor must also 
be scheduled from time to time. One responsent, however, seemed to feel that the assistant pastor has little to offer as far as the Sabbath sermon is concerned. He stated, "Many times the assistant pastor takes over the preaching service and I don't expect to take home a blessing." 1 Apparently this respondent has serious predispositions against assistant pastors as preachers. Has the senior pastor given the impression somehow that only he has a message for the church so that his parishioners only allow themselves to 1isten to him?" This is an urgent item for negotiation to avoid severe conflict.

How much time should the pastor spend on sermon preparation? of course no set number of hours may be given. Some may spend ten, fifteen, twenty, or thirty hours on a single sermon. A number of pastors may re-use previously prepared sermon material and adapt it to the current occasion, thereby saving much time. "It is the writer's opinion that most experienced pastors adapt previously prepared sermons and only-occasionally prepare a new sermon.

Should the focal pastor of this study spend more time in sermon preparation than in any other activity? This is the question reflected in item 60 of the questionnaire. The responses show that there is only slight favor at 2.85 on the scale, or nearly a "may or may not" response. This indicates that a considerable number of the respondents are willing for the pastor to decide for himself how much time he needs to spend in his sermon preparation.

$1_{\text {Ibid., number }} 136$. 
It is significant that the officers and deacons and the less-than-twenty-year-old age groups scored 3.15 and 3.05 , respectively, in their responses to question 60 . This indicates that these two groups were somewhat opposed to the pastor spending a disproportionate amount of time in sermon preparation. It may also reveal that they do not consider the sermon as being that influential. However, the over-fifty age group place a somewhat higher value upon this activity, as shown by their 2.57 median score. A determining concept might be that "preaching is a small part of the work to be done for the salvation of souls." 1

The time involved in sermon preparation was a concern of one respondent who asked, "When do pastors find time to prepare for sermons with all their expectations?" ${ }^{2}$

New worship innovations is the subject matter of item 61 of the survey form. It states that the pastor should develop new ways of worship and get away from the monotony of the traditional ways followed at present. One respondent seemed to be desirous of having a part in planning the worship service by stating, "It would be nice to have the church services conducted the way the members feel it is most interesting. Church members need to be involved in the church's activities. " 3

\footnotetext{
$1_{\text {White, Testimonies for the Church, }} 4: 69$.

${ }^{2}$ See exhibit $B$, number 45 .

${ }^{3}$ See exhibit B, number 136 .
} 
While the above remarks possibly favor certain innovations in worship, the responses of the majority of those surveyed tend slightly to oppose innovation in response to item 61 . However, at a 3.07 point it appears that there is a wide range of opinion on the matter of innovative-type worship services. Those under twenty years old and those who attend less than every week are most positively in favor, and those in the twenty-to-forty-nine age group were most opposed. This may be a source of conflict and needs attention by the pastor. It may be that the youth and others who do not attend regularly are unable to appreciate the traditional worship program as it is now conducted.

The sermon content is the consideration in item 62 of the survey. It states that the pastor conduct a Bible study occasionally on Sabbath morning rather than preach a sermon. A nearly divided response resulted from the survey at a 2.92 score for the total sample. It appears the Bible study idea in place of the Sabbath sermon does not appeal to many Seventh-day Adventists today. This is in spite of the fact that the church has a tradition of being a Bible-centered church. Instruction along this line was given by Ellen G. White:

Our people should not be made to think they need a sermon every Sabbath. Many who listen frequently to sermons, even though the truth be presented in clear lines learn but 1ittle. Often it would be more profitable if the Sabbath meetings were of the nature of a Bible class study.1

The respondents were even more equally divided concerning the suggestion found in item 63 of the survey form, that feedback 
sessions be conducted the week following the sermon presentation. The group who responded could hardly be more equally divided at a 3.02 median score. Of course, a high percentage of the respondents perhaps checked the "may or may not" response. This may indicate that the feedback idea is too new and unexplored to receive full endorsement. It is of interest to note that the younger the respondent the more in favor of feedback sessions he is, and the older the respondent, the less in favor. Those attending less than every week appear most in favor of feedback sessions, at 2.66 on the scale. This supports what was revealed in connection with the innovation suggestion found in item 61 .

Concerning the Pastor's Appeal in His Sermons and Bible Studies

In the light of the above discussion on content and feedback, item 76, part II, of the survey form may provide some added insight concerning the attitude of the focal congregation and conference group. It states that the pastor, in his sermons and Bible studies, should, according to answer A, emphasize the importance of obtaining eternal life through Christ in the future or, answer $B$, emphasize the importance of finding a richer more joyful personal life on earth through Christ in the here and now. The number, percentage, and Chi-square tests of the responses may be analyzed by the reader by examining table 28 . It is noted that the respondents were almost equally divided on this issue with 47.4 percent favoring answer $B$, a present-oriented appeal, and 45.5 percent favoring answer A, a future-oriented 
TABLE 28.--Number and percentage of responses by congregation and ministers concerning sermon and Bible-study emphasis of the pastor of the Grand Rapids Central SDA church in reply to the statement: Should the pastor base his appeal upon the future or the present?

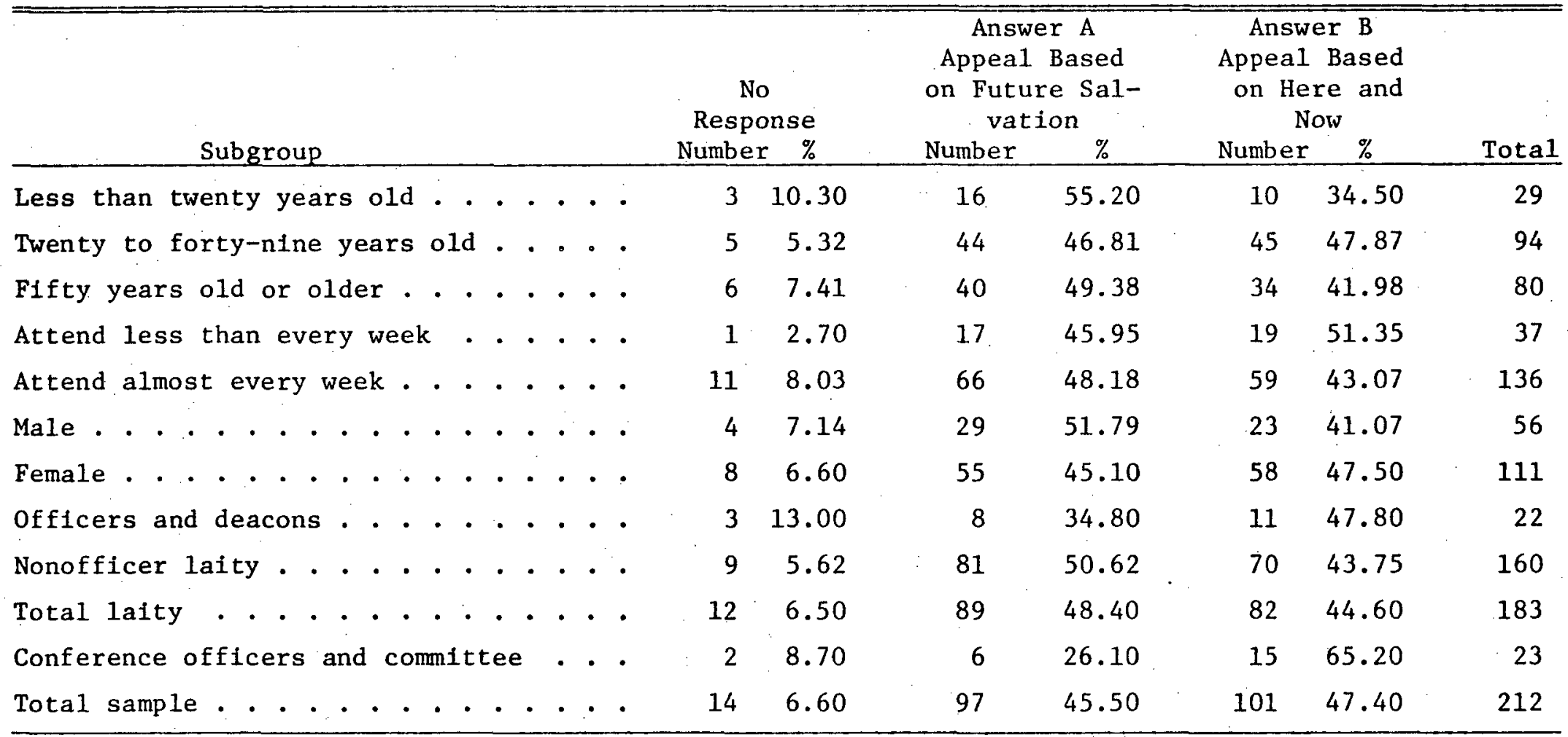

\begin{tabular}{lllll}
\hline Chi-square tests: & $=.6303$ & df $=1$ & $p=.427$ \\
Male - Female & $=.3447$ & df $=1$ & $p=.557$ \\
Under Fifty - Over Fifty Years 01d & $=1.3170$ & df $=1$ & $p=.251$ \\
Officers and Deacons - Nonofficer Laity & $=.3482$ & df $=1$ & $p=.555$ \\
Attend Every Week - Less than Every Week & $=.35$ & df $=1$ & $p=.440$ \\
Officers and Deacons - Conference Group & $=.0595$ & $=1.7461$ & $\mathrm{df}=1$ & $\mathrm{p}=.031$ \\
Nonofficer Laity - Conference Group & $=4.1233$ & $\mathrm{df}=1$ & $\mathrm{p}=.042$
\end{tabular}


appea1. There was some disagreement between the conference group and the laity in their responses to item 76. As will be seen on Table 28, 65.2 percent of the conference group favored answer B, and only 26.1 percent answer A. Whereas only 44.6 percent of the laity favored answer B, and 48.4 percent favored answer A. The laymen tend to prefer a future-oriented appeal by the pastor, whereas the conference committee members and ministers are more in favor of a present, here and now, appeal. The almost even division, however, between the various groups should caution the pastor against being too onesided either way in his appeals for decision. He may, on occasion, need to use both motivations if he is to appeal to all segments of his role set.

The Analysis of the Responses Concerning the Pastor's Role in the Prayer Meeting

Another regular appointment for which the 1ocal SDA pastor is traditionally responsible is the midweek prayer service. In many SDA churches the midweek prayer service is poorly attended by the members. The pastor is responsible for the service and often finds himself with a greater challenge to maintain a high level of interest on the part of the members in this service than in any other service of the church.

Two items of the survey were directed at the focal pastor's responsibility to the midweek prayer meeting service. Item 58 states that the pastor should conduct the midweek service, even though only a few people attend the meeting. A fairly positive response from the total sample at a 2.25 median score indicates 
that the majority feel the pastor "preferably should" function In this capacity. The over-fifty age group were slightly more Insistent at 2.09 on the scale. Perhaps more of the older age group attend the prayer meeting. They are possibly a little more traditionally oriented than those younger in years.

A second question concerning the prayer meeting responsibility of the pastor, item 59 , states that the pastor ought to be present at the meeting but invite others; such as the assistant pastor and the church elders, to help conduct the service. Although there was some favor shown to this plan at a 2.24 score, the insistence in not overwhelming. There was a high level of agreement among the respondents on the suggestion that others be asked to participate in the prayer meeting service. The conference group, at 2.45 on the scale, seem to be slightly less in favor of involving others than the laity, at 2.20.

It appears from this brief survey of the expectations of the pastor concerning the prayer services that the respondents would favor the pastor being present but utilize others in helping to conduct the service. Again this may be an area for negotiation. It may be that the laymen themselves have suggestions as to what to do to stimulate a greater interest by the church members in the prayer meeting. 
Summary of the Analysis of the

Pastor's Preaching and Worship

Functions

The survey taken revealed certain attitudes and concepts concerning the Sabbath and midweek services in the focal church. In summary the following ideas stand out:

1. Except for the matter concerning the pastor's three or more Sabbath preaching appointments per month, the respondents reveal a considerable division among themselves concerning such matters as the time for sermon preparation and worship innovations. Worship innovation may be too new and strange to many to receive ready acceptance.

2. The pastor of the focal church of this study also faces a divided constituency concerning what is most appealing in his sermons and Bible studies. The respondents were about equally divided between a future-oriented appeal and a present-oriented, here and now, appeal.

3. A high degree of unity, however, exists among the respondents concerning the pastor being present and conducting the prayer meeting service, regardless of how well attended it may be. A certain amount of traditionalism may be seen among the respondents as far as prayer meeting is concerned. Possibly new innovations may be introduced to stimulate interest. There is some indication that this would be acceptable to the respondents.

Closely related to the preaching and worship functions of the pastor are the teaching and training responsibilities. In fact, there are some who may see the pastor more in these roles 
than as a preacher and leader of worship. It is to the teaching and training functions of the pastor that the final section of this survey analysis is directed.

\section{Section VII--Analysis of Responses Concerning Teaching and Training}

Jesus was a teacher as well as a preacher. Both functions are closely associated. Preaching may include a great deal of teaching and, contrariwise, teaching may include some preaching. The two, however, stem from two different original New Testament words. Preaching comes from the Greek word, unpujorelu, to pro-

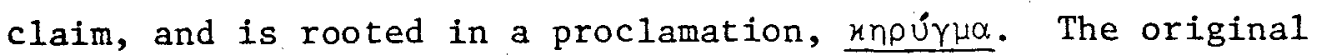
word, $\delta\llcorner\delta \alpha x \varepsilon \cup v$, means to teach and is the source of the modern didactic method of communication.

The only gift the apostle Paul associated with the function of the pastor was the gift of teaching (Eph 4:12). This teaching ministry, along with the other gifts mentioned in Eph 4:11 and 12, is said to be for the purpose of "perfecting the saints, for the work of the ministry." One concludes that the pastor-teacher is to train others so that they may be more effective in their ministry. However, the pastor is not to lift the load of responsibility from the laymen's shoulders. The success of the church's mission depends much upon the pastor's ability to inspire, to teach, and to train the members or "fellow ministers" already in the church.

The SDA pastor is particularly urged to function as a teacher and trainer. In the writings of his chief counsel, 
Ellen G. White, he is told that he should "devote more time to educating than to preaching." 1 The pastor is "to teach them [the laity] to work for God and to depend on Him and not on the ministers." 2

Furthermore, to help his members in the best way possible, the pastor is told, "The best help that ministers can give members of our churches is not sermonizing but planning work for them." 3 Finally he is told, "The people have had too much sermonizing; but have they been taught how to labor for those for whom Christ died. " 4

The reason why teaching and training is urged so strongly, especially for SDA pastors, may be partially due to the unique differences between the church and most other Christian denominations. The new convert must make considerable adjustment in his religious concepts and life style. This requires patient teaching and training on the part of the local religious leader in the SDA church. Also, should the newly converted member wish to become a witness, additional training will be needed.

It is concerning the teaching and training roles of the local SDA pastor that section VII of the survey form is directed. Items 64 to 69 of this section include matters pertaining to the pastor teaching the pastor's Bible class, instructing candidates for baptism, training laymen for witnessing, and ministering to the youth. Table 29 gives the median response summary for this section.

1 White, Testimonies for the Church, 7:20.

2 Ibid., 7:19. 3 ${ }^{3}$ Ibid., 9:82. 3 Ibid., 6:431. 
TABLE 29.--Median responses of the congregation, conference committee, and certain ministers concerning teaching and training expectations of the Grand Rapids Central SDA pastor

\begin{tabular}{|c|c|c|c|c|c|c|c|c|c|c|c|c|}
\hline $\begin{array}{l}\text { Instrument } \\
\text { Number and Statement }\end{array}$ & 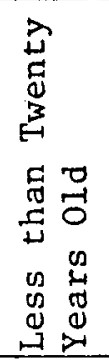 & 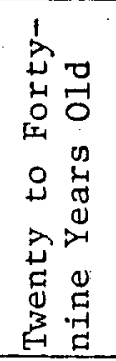 & 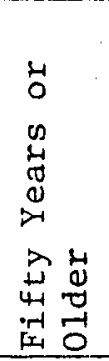 & 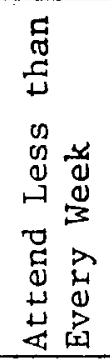 & 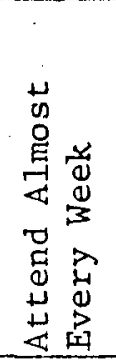 & $\stackrel{0}{\stackrel{3}{\Sigma}}$ & 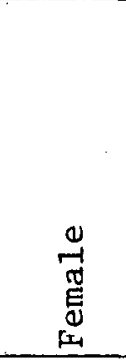 & 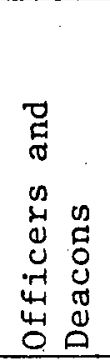 & 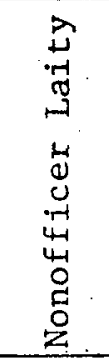 & 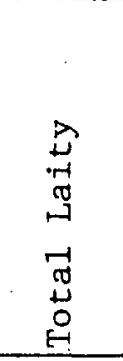 & 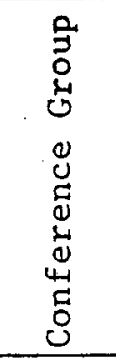 & 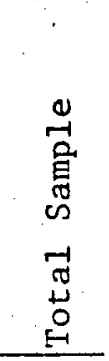 \\
\hline $\begin{array}{l}\text { 64. Teach pastor's Bible class } \\
\text { when present. . . . . } \\
\text { 65. Personally instruct those } \\
\text { preparing for baptism. } \\
\text { 66. Never baptize anyone with- } \\
\text { out thorough instruction } \\
\text { 67. Direct the witnessing } \\
\text { training program. . . } \\
\text { 68. Most of youth ministry } \\
\text { should be done by the } \\
\text { assistant . . . . . . } \\
\text { 69. Delegate others to lead } \\
\text { in ministry for children, } \\
\text { youth . . . . . . . . }\end{array}$ & $\begin{array}{l}2.32 \\
1.69 \\
1.56 \\
2.69\end{array}$ & $\begin{array}{l}1.80 \\
2.62 \\
1.27 \\
2.21\end{array}$ & $\begin{array}{l}1.72 \\
1.42 \\
1.26 \\
2.18\end{array}$ & $\begin{array}{l}1.86 \\
1.41 \\
1.39 \\
2.09\end{array}$ & $\begin{array}{l}1.84 \\
1.54 \\
1.28\end{array}$ & $\begin{array}{l}1.83 \\
1.50 \\
1.26\end{array}$ & $\begin{array}{l}1.83 \\
1.54 \\
1.32\end{array}$ & $\begin{array}{l}1.72 \\
1.46 \\
1.13\end{array}$ & $\begin{array}{l}1.84 \\
1.52 \\
1.36 \\
2.30\end{array}$ & $\begin{array}{l}1.83 \\
1.51 \\
1.32 \\
2.30\end{array}$ & $\begin{array}{l}1.80 \\
1.64 \\
1.19 \\
1.96 \\
2.56\end{array}$ & $\begin{array}{l}1.84 \\
1.51 \\
1.31 \\
2.25\end{array}$ \\
\hline
\end{tabular}

Median figures are based on a range of one to five as follows: 1 - Absolutely must 2 - Preferably should 3- May or may not 4 - Preferably should not 5 - Absolutely should not 
The Analysis of the Responses

Concerning the Pastor Teaching

the Pastor's Bible Class

Some SDA pastors prefer to be free from teaching responsi-

bility during the Sabbath School period each week. They apparently

feel they are thus able to minister to a wider group than just

a small class. Other pastors feel that by conducting a class for

them this is a good time to orient new and prospective members into

the doctrine and fellowship of the church. Question 64 was de-

signed to obtain an attitude from the respondents on the question

whether the pastor ought to function as a teacher of a Sabbath

School class or not.

The general consensus of the respondents was a strong "pre-

ferably should," at a 1.84 median value. There appears to be little

doubt about this matter among any of the groups except the lessthan-twenty-year-oid age group, at a 2.32 median score. The youth may feel that if the pastor teaches a Sabbath School class every week he may be too involved to ever have opportunity to meet with them. The writer personally prefers to teach a class, however, it may be that some negotiation here is necessary to please all segments of the church.

The Analysis of the Responses

Concerning Instruction for

Baptismal Candidates

Items 65 and 66 on the survey form are very similar in

their intent. Item 65 states that the pastor should personally supervise the instruction of those he plans to baptize. This 
implies that he may personally do the instructing or he may delegate someone else to perform the task under his supervision. The response for the total sample was very insistent at a 1.51 median score. There was no significant disagreement between any of the subgroups on this matter.

Item 66 states that the pastor should never baptize anyone without thoroughly instructing them beforehand. This may seem to be an obvious duty of the pastor. However, among SDA evangelists there seems to be a tendency for some to hasten the baptismal rite without duly instructing beforehand. To obtain the sentiments of the respondents, the question concerning prebaptismal instruction was included in this survey.

The response of the total sample was a 1.31 score indicating that most respondents urge the pastor to instruct his baptismal candidates thoroughly before the baptism. Apparently the laity see the problem that is created for the church when persons unite without a thorough acquaintance with the church's unique doctrinal positions. The writer is inclined to favor thorough instruction of baptismal candidates before their baptism. There may be a few exceptions such as a person who is already well acquainted with the church's beliefs and practices. Even then a review should be in order.

An Analysis of the Responses Concerning Witnessing Training for Laymen

As a teacher-trainer, the SDA pastor will be expected to train his parishioners to witness for their faith. Item 67 of 
the survey states that the pastor should personally direct the witnessing training program by means of on-the-job training plus classes. This plan of training the laity in witnessing is highly recommended at the present time in the SDA church. It is the plan strongly endorsed by E1len G. White in these words: "There should not only be teaching but actual work under experienced instructors. "1

The respondents scored at a 2.25 median point on the oneto-five scale. While this is positive, it is not as positive as one might expect in the light the apparent concern for evangelism reflected earlier in this study. Perhaps the layman finds himself, like his pastor, too involved in many other matters to devote much time to evangelistic witnessing. This may prove to be an invalid excuse in the light of the urgency that characterizes the SDA movement.

An Analysis of the Responses Concerning Ministry for the Youth

Because there is assigned to the senior pastor of the focal church of this study an assistant pastor, and because the assistant is usually younger in years than the senior pastor, he is often expected to work primarily with the youth. This may be determined by the two pastors themselves. However, it does not deny the senior pastor the opportunity to conduct a ministry for the youth should he be willing and able to do so. 
Item 68 of the survey states that the senior pastor should turn over most of the youth ministry to the assistant pastor. The respondents scored at 2.40 on the scale. This indicates that, while most favor such a plan, the respondents are not overly insistent that such a plan be followed. The respondents may see this as an area that should be decided by the pastor and his assistant, hence the lack of strong conviction on the issue. There was, however, slightly more. insistence that the assistant pastor conduct the youth ministry on the part of the under-twenty age group and those who attend irregularly. Perhaps this may be seen both by the youth and the irregular attendants as a way of having some pastoral assistance from the pastoral staff. Item 69 was very similar to item 68 in stating that the pastor should show interest in the youth but delegate to others the actual ministry for the children and youth. The responses indicate that this is even more acceptable, at a 2.05 or "preferably should" point of the scale. There appears to be much unity among the respondents on this issue.

A few respondents indicate some concern that the senior pastor show interest in the youth. For instance one respondent, an officer of the church, wrote, "The Grand Rapids pastor should show interest in all departments of the church including the youth department and community services."1

\footnotetext{
${ }^{1}$ See exhibit $B$, number 26 .
} 
Summary of Analysis Concerning

Teaching and Training

Little apparent conflict appeared among the various subgroups in their responses to the issues involved in section VII of the survey. The survey reveals that respondents favor the pastor teaching a pastor's Bible class and instructing the candidates for baptism thoroughly before their baptism; and they indicated they would cooperate in an on-the-job witnessing training program. However, the respondents do not indicate a really strong willingness to be trained for witnessing. This supports the analysis concerning the laymen becoming involved in evange1istic endeavors, that the enthusiasm tends to wane on the part of many laymen when it comes to being personally involved in witnessing.

The respondents seem to feel the pastor ought to have an interest in the youth and perform some type of ministry in their behalf. However, it appears that, due to the heavy work load the senior pastor carries, the assistant pastor would likely perform much of the youth ministry in the focal church. This should provide an important area for negotiation for the pastors as well as for those involved in the local congregation.

\section{Summary of the Analysis of the Responses} to the Survey Form

The focal church of this study and the conference personnel included in the survey represent a wide diversity of backgrounds, as well as educational, social, and economic differences. It is 
to be expected, therefore, that in a survey of this type considerable disagreements could arise. The study has not disappointed this prediction. It is the interest of this summary to note the number of items on which the subgroups disagreed with one another, to study these items themselves, and to attempt to draw some conclusions.

In the analysis of the questionnaire just completed most of the items on the questionnaire were analyzed upon the basis of a median response score for each of the subgroups and the total sample. The median score reflects the general consensus of the responding group or groups. This was done in order to simplify the discussion and reduce the length of the analysis. A table of median responses was provided for each section of the questionnaire. Also items $71-78$ of part II of the survey form were explained by individual tables including number of responses, percentages, and Chi-square tests.

To aid in this summary a complete list of items that created significant disagreement between one or more pairs of subgroups is provided in table 30 . The section of the questionnaire, item number, and a brief description for identifying the issue involved is included in the table. The disagreeing subgroups are listed in table 30. Only those items are included over which certain pairs of subgroups disagreed in their responses.

In order to determine the degree of disagreement on any given issue in this survey a Chi-square test was applied. A 
TABLE 30.--Summary of items which created significant disagreement between certain pairs of the subgroups based on Chi-square tests

\begin{tabular}{|c|c|c|c|c|c|c|c|c|}
\hline $\begin{array}{l}\text { Section and } \\
\text { Issue Number } \\
\text { Involved }\end{array}$ & 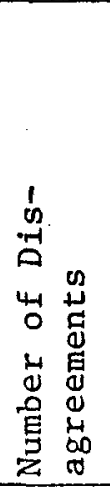 & 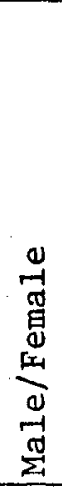 & 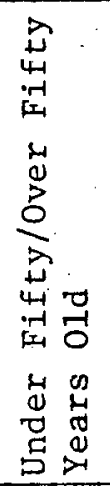 & 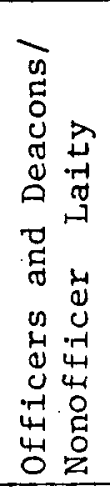 & 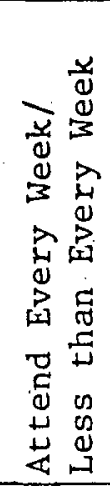 & 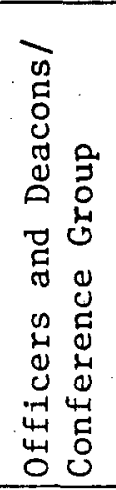 & 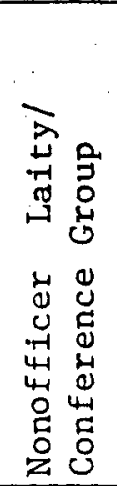 & 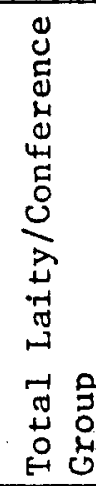 \\
\hline \multicolumn{9}{|l|}{ Section I } \\
\hline 2. Ex-officio on a11 committees & 2 & & & & & & .010 & .027 \\
\hline 3. Do the fund raising & 2 & & & & & & .045 & .053 \\
\hline 4. Personally direct the ingathering & 3 & & & & & .040 & .014 & .007 \\
\hline 8. Do own office work & 3 & & & & & .018 & .025 & .014 \\
\hline 10. Wife act as secretary & 3 & & & & & .032 & .037 & .029 \\
\hline 11. Chief public prayer & 4 & & .022 & & .056 & & .011 & .021 \\
\hline 13. Chief strategy planner & 2 & & & & & & .064 & .080 \\
\hline 15. Conference committee & 2 & & & & & & .037 & .034 \\
\hline 17-B. Pastor's council leader & 1 & & .071 & & & & & \\
\hline 17-C. District emergencies & 1 & & & & & & & .068 \\
\hline \multicolumn{9}{|l|}{ Section II } \\
\hline 19. Ministerial Association member & 2 & & .015 & & .089 & & & \\
\hline 23. Delegate writing of news articles & 1 & & & & & & .043 & \\
\hline 24. Be a public relations agent & 3 & & .032 & & & & .043 & .082 \\
\hline \multicolumn{9}{|l|}{ Section III } \\
\hline 26. Personally do Bible work & 3 & & .024 & & & & .022 & .031 \\
\hline 27. Be a trainer of laymen & 3 & & & & & .048 & .001 & .001 \\
\hline 29. Train rather than do evangelism & 1 & & .086 & & & & .052 & .108 \\
\hline
\end{tabular}


Section and Issue Number Involved
The

Issue

Involved

Section IV

38. Visit shut-ins every month

40. Visit member families every two years

41. Always pray when visiting

43. Counsel any and a11

Section $V$

45. Regular time for devotions

46. Improve by triall and error

48. Possess M.Div. degree

49. One day off each week

50. Spend hour per day free

51. Wife be a volunteer church worker

55. Children be good examples

Section VI

57. Conduct three Sabbath services per month 60. Spend more time in sermon preparation

63. Feedback sessions on Sabbath sermon 


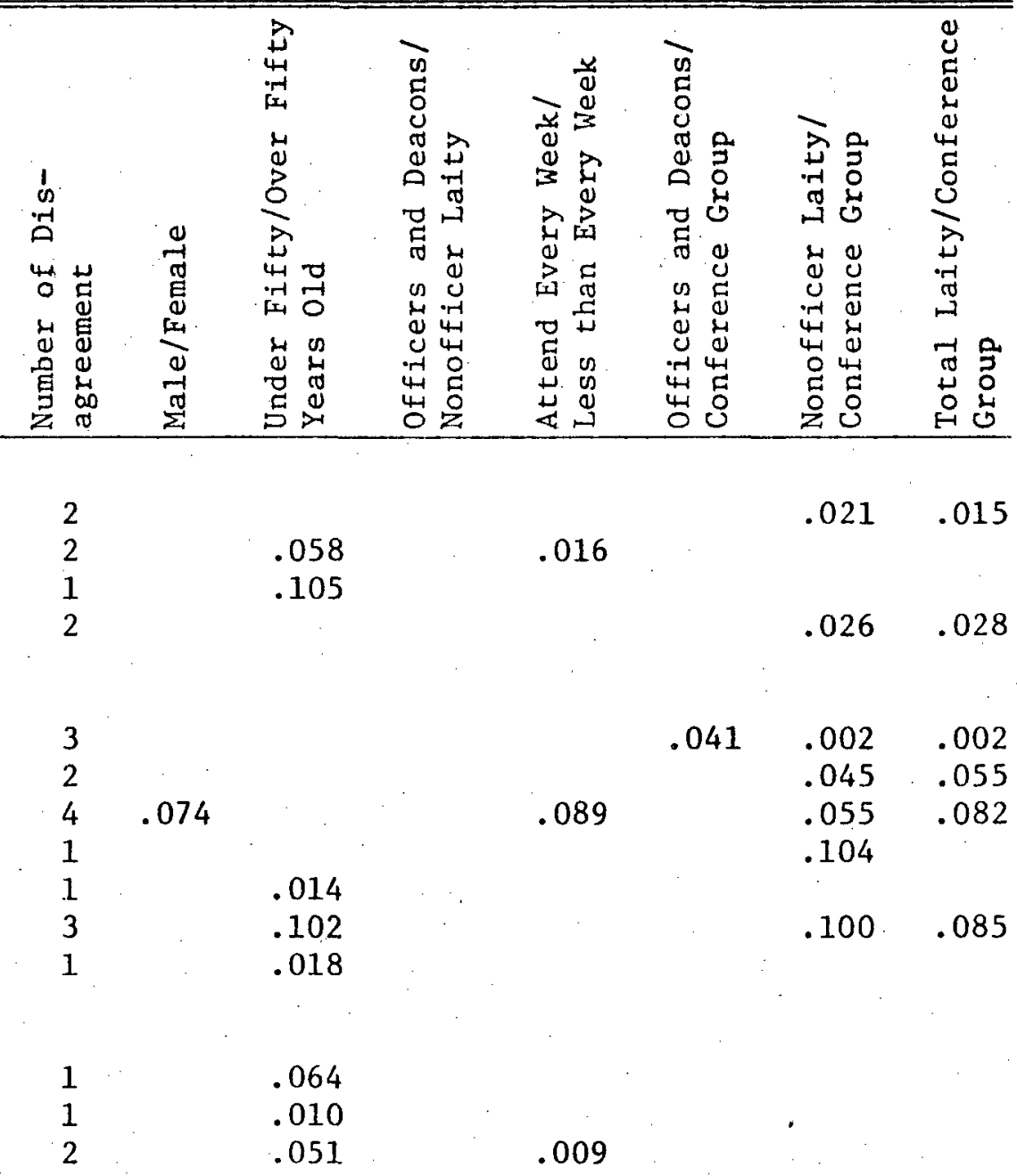


TABLE 30 (Continued)

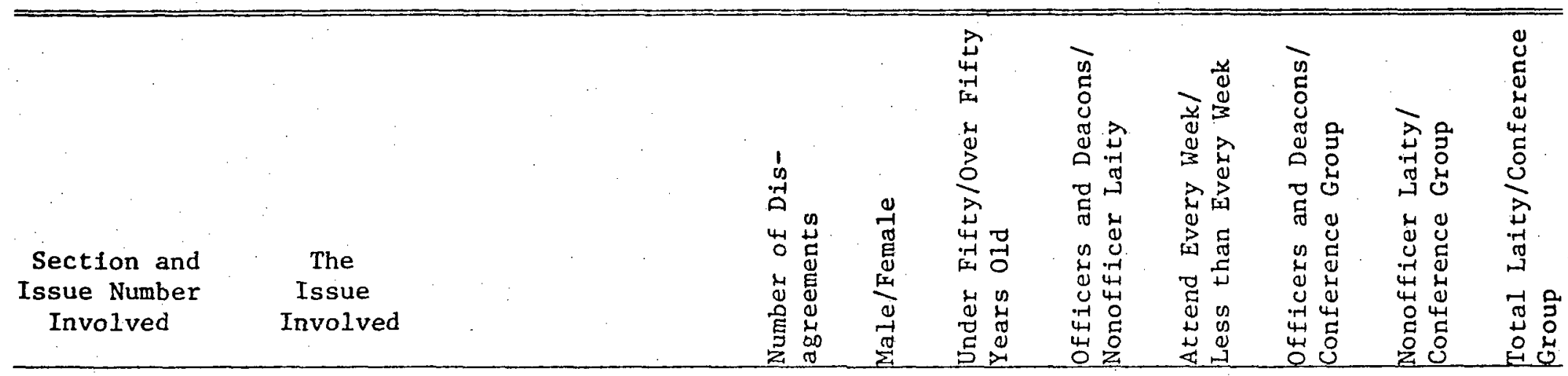

\section{Section VII}

68. Give over youth work to assistant pastor

1

.005

\section{Part II}

$\begin{array}{ll}\text { 71. Traditional religious counseling vs. psy. } & 3 \\ \text { 72. Involved vs. non-volvement in civic affairs } & 5\end{array}$

73. God-centered vs. human-centered call to min. 3

74. Non-directive vs. directive counseling 1

76. Future-oriented vs. present-oriented appeal 2

77. Participative vs, autocratic administration 3

$\begin{array}{cccccc} & .020 & & & .083 & \\ & .001 & .060 & .051 & .053 & .078 \\ & & .076 & & .028 & .083 \\ .035 & & & & & \\ & & & & .031 & .042 \\ & .027 & & & .026 & .031\end{array}$

Disagreement is significant if .10 or less 
simple explanation concerning the benefit of this test may be useful to the reader. This test compares the actual number of responses on a given item with the expected number of responses. The expected number is determined by comparing the responses of one group with the responses of one or more other groups. If the groups are in full agreement the probability percentage will equal 1.000. The greater the disagreement between the groups, the lower the probability percentage becomes. In this study disagreement between subgroups is seen as significant if the probability percentage equals .10 or less in the Chi-square test.

It is customary in attitudinal measurements to break at .10. However, it is possible that in some instances that a higher percentage may be seen as significant. Also it may be that a lower than .10 percentage only is significant. The .10 percentage of disagreement provides a standardized breaking point that is helpful for interpretative purposes.

A brief glance at table 30 will reveal to the reader that the respondent groups and subgroups disagreed on thirty-seven of the eighty-one possible issues on the questionnaire. ${ }^{1}$ The probability percentages provided on table 30 show that in each case the percentage is .10 or less. It is concerning these thirtyseven items that the greatest attention should be given to determine sources of potential conflict within the role set.

${ }^{1}$ Item 17 includes three parts and item 70 contains two parts making a total of eighty-one separate issues in this survey. 
It is of interest to note that certain items listed on the survey form involved more pairs of subgroups in disagreement than other items. The reader will notice that twelve items involved only one pair of subgroups in significant disagreement; eleven items involved two pairs of subgroups in significant disagreement: eleven items involved three pairs of subgroups; two items, 11 and 48, involved four pairs of subgroups in significant disagreement; only one item, number 72 , concerning the pastor's role in civic affairs, involved five pairs of subgroups in significant disagreement.

It is to these specific items that the pastor will need to pay particular attention. They will provide the pastor, his congregation, and his conference officials helpful input in negotiating the pastor's role and position in the church. A particular concern may be required on those items that involve a multiple number of the subgroups in disagreement.

It is of further interest to note the number of times each of the seven pairs of subgroups differed and on which item of the survey they differed. There was more or less disagreement between each pair of subgroups. However, certain subgroups appear to think very much alike. For instance the male/female subgroups were most often in complete agreement. There was no significant disagreement between these two groups except for item 48, concerning the pastor's educational qualifications, and item 74 , concerning his counseling techniques. 
There was also considerable agreement between the officersand-deacons/nonofficer-laity groups. Out of the eighty-one possibilities these two groups disagreed on only three items. These include numbers 71 , concerning counseling resources for the pastor, item 72 , concerning the pastor's civic involvements, and item 73, concerning the pastor's motivation call to the ministry. Two other groups that seemed to agree quite frequently were the conference/officer-and-deacon groups. In only five instances did they disagree significantly in this survey. These disagreements included such matters as the pastor's role in the Ingathering program, doing his own office work, his wife acting as his secretary, and the pastor's devotional life.

A higher number of disagreements occured between those who attend almost every week and those who attend less than every week. These two groups disagreed significantly on seven items of the survey form including such matters as whether the pastor should be a member of the local ministerial association, his academic qualifications, feedback sessions for Sabbath sermons, and involvement in civic affairs.

A much more frequently disagreeing pair of subgroups was the over-fifty-years-of-age/under-fifty-years-of-age groups. They disagreed significantly on fifteen separate items. The disagreements included such issues as whether the pastor should be the chief public prayer, should visit every member family every two years, and what should be his counseling resources. 
Finally, the largest number of disagreements occured between the conference/nonofficer-laity groups which totalled twenty-five out of the possible eighty-one issues in the survey. This indicates that in a very real way the ministers conceive of the pastor's work in one way and the laity conceive of his work in another way. The conference/total laity disagreements paralleled closely those of the conference/nonofficer laity. Among the more significant items upon which it appears the laity disagree with the conference officers and ministers are matters pertaining to the Ingathering program, lay training, the pastor's educational qualifications, pastor's wife, involvement in civic affairs, and sermon and Bible study appeals.

The analysis provided considerable information concerning the attitudes and preferences of the local congregation and significant others in the pastor's work life. Much more may yet be learned from this survey. A rich source of information concerning the attitudes of many in the congregation came from the personal comments, questions, and suggestions section of the questionnaire. Over seventy of the respondents wrote something of interest to the researcher. Those voluntary comments having to do with the survey, the program of the church, or the work life of the pastor may be perused by turning to the appendix, exhibit $B$.

It appears that the thesis proposed in this study concerning the existence of conflict between the significant others in the SDA pastor's work life has been proven correct. It is evident from the survey that the greatest amount of potential 
conflict exists between the old and the young and between conference employees and the laity. All such conflict may provide the pastor and his congregation opportunities for negotiation and growth. On the other hand it may be a source of frustration, discouragement, and defeat for the pastor and his congregation. Much depends upon how well the knowledge gained is used. 


\section{CHAPTER VII}

\section{EVALUATION AND CONCLUSIONS}

This final chapter is an attempt to evaluate the benefits of the project to the writer and its possible significance to the Seventh-day Adventist ministry in general. It is designed to provide a reflective overview of the project as it has developed and to survey the conclusions that have been reached.

\section{Concerns and Reflections}

One of the concerns of this study was to "suggest a model that SDA pastors may use to reduce role overload, conflict, and ambiguity within their pastoral setting. "1. The verbal model suggested is referred to as an intentionally negotiated ministry. The process includes an analysis of the focal person, the pastor, and an analysis of the pastor's role set, which includes his family, his church, his conference officers, and committee members. It is one of the theses of this study that the pastor of a local SDA church experiences conflict, ambiguity, and overload in his relationship with his role set. This, it appears, has been amply proven. By simply comparing the responses of selected subgroups to specific items on the questionnaire, one can readily

\footnotetext{
${ }^{1}$ See chapter I, Introduction, p. 13.
} 
discern significant disagreement over thirty-seven separate items. 1 Furthermore, it was found that the pastor of the focal church of this study spends fifteen to twenty hours more at his work per week than the role set expects of him. Consequently, either the pastor is experiencing work overload or he is overworking himself voluntarily. While no final answer may be possible it appears that a real possibility exists in the pastorate of this study for work overload.

In view of the above it appears that the church and conference is willing to enter into new approaches to ministry. There is evidence that a willingness to improve is in the minds of many.

New Approaches to Ministry are Acceptable

First among the evidences that the above conclusion is true is the fact that when conceiving this project, the writer received favorable reaction from both the local church members and leadership as well as among the conference leadership. Furthermore, there. was no known resistance to the circulation of the survey form from among any of the above-mentioned groups. On the other hand, there were many who expressed considerable interest in what was being attempted in the project. One respondent asked, "Could the church members receive a copy of this survey with its combined results?" ${ }^{2}$ The writer has promised to comply with this request.

${ }^{1}$ See table 30 page 251.

${ }^{2}$ See exhibit $B$, comment number 131 . 
A complimentary copy of the total project is to be presented to the church in appreciation for the congregation's part in this study. The conference officials will also receive a copy.

Apparently some of the respondents found the survey stimulating to their church life as is indicated by one person who states, "I've done some studying and I feel I have a clearer outlook on the function of a minister. It is almost like looking into a new world. . . This is your project, but the subject matter is a new, fascinating study for me in my church life." 1 Another respondent stated that "these questions . . . I feel should be strongly considered by all pastors, especially in taking up the duties of a new congregation." 2

It is evident that the local SDA pastor has considerable freedom to implement new approaches to minsitry in his local church. This freedom may, however, be limited by certain factors. Limitations to new approaches to SDA ministry. One of the determining factors to implementing new models for ministry in the local church is the degree of trust exisitng between the pastor and his role set. If all have confidence that the pastor will not abandon local and denominational church traditions and if there is confidence that he has the best interest of the total church program in view, the pastor should not have difficulty suggesting new approaches to ministry. Furthermore, if there is a spiritual

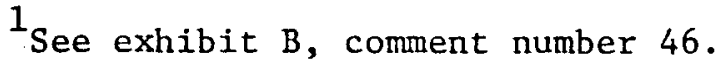

${ }^{2}$ Ibid., number 65 .
} 
legitimacy undergirding the new approach, it will be more acceptable. No new model is likely to be acceptable to local SDA churches or conferences unless there is support from the Bible and denominational literature.

Another factor that assists the pastor when introducing new models for ministry is the success factor. If the pastor has had some degree of success in the local pastorate it provides him with some strength in the introduction of new concepts of ministry. However, it should be added that success in the ministry is such a relative matter that the pastor should not let this be a serious issue as to whether he introduces new approaches to ministry in his local church.

This Project Reveals a Need for a. Negotiated-Type Ministry in the Local Seventh-day Adventist Church

The SDA pastor like his Protestant counterpart is experiencing considerable stress in his ministry. Much of this is caused by a lack of understanding among the significant others that are a part of the pastor's role set concerning his life and work.

The large number of issues in the survey over which there exists significant disagreement between the various segments of a local SDA pastor's role set indicates an urgent need for negotiation. The issues over which disagreement exists range from the pastor's role in the annual Ingathering program to his academic qualifications; from the pastor's role in civic affairs to his leadership style; and, from the role of the pastor's wife in the local church to whether the pastor should be provided a church 
secretary. The need for some form of negotiation between the pastor, his congregation, and his conference is urgent. As a means of fulfilling the mandate of Jesus Christ to carry the gospel to the world the church will find a negotiative approach to ministry productive of greater results.

Besides the evident lack of total agreement between certain groups of the SDA pastor's role set additional factors urge him to negotiate an intentional ministry. These were elaborated on in chapter III, pages 68-72. Those mentioned were the need to be intentional, the need to recognize the voluntary nature of the church, the need to see the church as heterogenous, the need to Include both the local church and conference, and the need to provide some alternative to frequent pastoral transfers.

The Project Reveals that the Focal Pastor of this Study may Experience Role Overload

Role overload is simply having too many roles at any one time. This may lead to reduced effectiveness in the roles that are accepted.

This study reveals that the pastor of the focal church actually averaged 10.5 hours per day in his work. ${ }^{1}$ This was based on a twenty-five-day period when the records were kept. of course other persons and other pastors may spend equally as much time at their work or more. It is to be observed that this

$$
1_{\text {See }} \text { chapter IV, p. } 90 .
$$


average is based on a seven-day work week and that the weekly average thus was 73.5 hours.

The multi-role position of the pastor may appeal to many and be a source of challenge to them. To others it may make demands that they do not have the capacity or inclination to fulfill. Much depends upon the pastor and his capacities for work as well as his family needs and the amount of time and energy he is able to invest in his work. If the demands of the position do not match his capacities, he will experience role overload.

As a pastor the writer devoted as much time in his work as he felt he could without jeopardizing his health and capacities for work. It appears he was giving more than necessary to satisfy his role set. He will need to review this issue and determine whether he is letting his work fill the time he has or whether he is planning his time to meet the needs of his work. It is an issue for negotiation with the significant others in his work life.

It is true that a pastor has little difficulty changing his activity with so many roles to choose from. He has, therefore, much more variety in his work and may spend more time in work-related activity without tiring than can employees in certain other. repetitive-type occupations. Nevertheless, it is no doubt wise for pastors to spend some time fully away from their work each week. The writer may need to study further his own use of time and seek a balance that is compatible with all his significant others. 
Personal Goals--Assessment

The writer's personal objectives in this study were:

to analyze the attitudes of a local Seventh-day Adventist congregation and conference towards the life and work of the pastor, (2) to obtain materials concerning principles of church leadership that may be shared both with ministers in training and with those in the field, (3) to gain insights to personal strengths and weaknesses, and (4) to obtain information in order to make a midcareer self-assessment to guide him in the choice of a specific ministry. 1

The project was conceived about the middle of the first year of the writer's tenure as pastor of the Grand Rapids Central Seventh-day Adventist church. It became, therefore, an in-ministry project for the remainder of the time in that pastorate.

The benefits of the project appeared in the writer's pastoral ministry as soon as research of the literature on the subject began. The ongoing reading and occasional opportunity to gather materials developed concepts that were immediately applicable in some cases to the ministry. The new concepts were helpful in keeping a fresh view of what the pastoral ministry is all about. However, there were some limitations of the benefits of the project to the writer while serving as pastor of the church in this study. One was a lack of adequate time to spend on the formulation of the concepts into practical application in the

${ }^{1}$ See chapter I, Introduction, p. 14. 
pastorate. Often the writing would be set aside for several weeks before it was taken up again. This proved to be a frustration in that the writing was not being done and time was not available to devote to it.

To resolve the frustration, the writer proposed a pian by which more of the church responsibilities could be transferred to the assistant pastor and more time allowed to the writer to complete his written report. The proposal, while not totally rejected, was not met with full approval by the local lay leaders nor the conference officials. To complete the writing it became apparent to the writer that he must give up his pastorate. This was done at the end of September 1976.

Because the project had not taken full shape the writer was unable to demonstrate the suggestions of a negotiated ministry in the focal church of this study before he left the pastorate. The implementation aspect may be worthy of further study and application in another project. However, a few suggestions for negotiating may be helpful.

Suggestions for Implementing a Negotiated Ministry

With the information contained in this project in hand, the pastor has sufficient materials for negotiating with his congregation. Some means must be devised so that the information may be transmitted to his role set.

It appears to the writer that the following steps are a basic minimum that must be taken in any negotiation process in the local SDA church: 
1. Decide what issues are to be negotiated. This may require some preliminary work on the part of the pastor and his church board. The survey results may provide strong suggestions as to what direction the negotiation should take. The pastor may also have some personal goals he may wish to negotiate. The congregation may wish to negotiate its goals with the pastor. The list of issues that may need attention could become very long. Priorities must be established. This may be most ably done by the church board or a steering committee appointed by the board.

2. Organize the church into groups for open discussion. This too may best be done by the church board or steering committee. The groups should not become too large. As a guide, not less than six and not more than fifteen makes an effective discussion possible. Groups may be natural units such as a Sabbath School class, board of elders, deacons and deaconesses, youth under twenty, and so forth.

3. Devise a communication plan that reaches every member of the pastor's role set. One of the most effective ways of reaching every member is the postal system. A series of weekly articles prepared by the pastor concerning the negotiative model and the issues to be negotiated would possibly be sufficient. The telephone is perhaps almost as effective as the postal system. Of course the pastor may utilize the church bulletin for appropriate observations. A special brochure may be very useful as a basic negotiating manual for the pastor in the local setting.

4. Encourage fellowship within the negotiation process. The very existence of the church is determined by its fellowship. 
Negotiation implies fellowship or partnership in establishing programs, goals, and roles within the church. Much depends upon the spirit in which the process takes place whether the negotiation is successful. It is important that the fellowship is maintained throughout the whole process.

Fellowship may be encouraged more readily by organizing house groups. While these tend to be more informal, it may be more beneficial due to the nature of the occasion. The goal is to encourage participation on the part of as many in the congregation as possible. The "silent members" need to be heard as well as the more vocal ones. The pastor may find it convenient to invite certain leadership groups to his home for discussion and negotiation. He is thus encouraging the spirit of fellowship within the church. The conference officials may be invited to some of the fellowship and negotiation sessions where the pastor is present. They are thus included in the process, and at the same time they may thus be heard by the pastor.

5. Following a series of several group sessions a general gathering of the church is required to finalize on the recommendations of the various groups. This gathering may be conducted as a business session and may or may not be accompanied by a fellowship dinner. What emerges from the plenary session of the church is, hopefully, a new creation; a ministry that is unique and acceptable to the pastor involved and his congregation.

6. Finally, the suggested model requires some type of an evaluative plan that allows also for renegotiation on the part of 
the pastor and his congregation from time to time. An annual review session may be what is involved. It should be a time for renewal of the contract or a time to renegotiate a new contract in the pastorcongregation relationship. Thus through an ongoing negotiative relationship the pastor and his congregation may enlarge and expand the total ministry of their combined efforts.

\section{Positives and Negatives Concerning}

the Survey Form

To study the local church as an independent religious unit was a long sought desire of the writer. It became necessary to prepare and administer a questionnaire or survey form. This was the writer's first attempt to administer and obtain responses from a local church by means of a survey form. It became an extremely valuable learning experience.

The questionnaire was prepared, pre-tested, and distributed by the writer just prior to his leaving the focal pastorate of this study. The writer learned much through this experience both from his successes and failures. It appears a bit wider circulation for the purposes of pretesting would have been advisable. It was discovered too late, for instance, that items 14 and 35 were double negatives and ambiguous to the respondents. There were some who complained that some of the issues on the questionnaire were too dependent upon conditions, upon the pastor himself, or were too neutral and could draw only a "may or may not" response. 1 other

${ }^{1}$ See exhibit B, comment number 15 . 
respondents felt the pastor ought to be left in a free framework and the issues left to his discretion. 1

The above observations concerning the questionnaire are, no doubt true in some instances. However, the great majority of the issues did receive clarification from the study of the responses. It may be noted that a number of the issues are of such a nature that they ought to be left up to the discretion of the pastor. In other cases it is helpful to the pastor to know the opinions of his congregation and others in his role set.

As noted earlier there were a number who considered the survey form a valid instrument to measure attitudes within the church. This is what is was designed to obtain. Among the positive benefits the writer received from the questionnaire are the personal comments, suggestions, and questions by the respondents written at the end of the survey form. ${ }^{2}$ These reflect a wide range of opinion both concerning the writer as pastor, the survey form itself, as well as the local church and its program. Because a number of the comments were very personal these were deleted from the list found in the appendix, exhibit $B$. Only those that have bearing on the life and work of the pastor, the church, and general observations are included.

These personal comments, suggestions, and questions provide the writer and the reader with a deeper insight to the thinking of the local congregation on a wide range of issues. It

${ }^{1}$ Ibid.:, number 108.

${ }^{2}$ see exhibit $B$. 
is valuable feedback from a large segment of the local church. Most of the remarks are pertinent and clearly reflect the attitude of the respondent. Coming at the end of nearly three years in the pastorate the written personal responses were of special benefit to the writer, the initiator of this study. It has been an education to the writer and has informed him as to which programs, innovations, and attitudes on his part were most effective and which were not.

An Enlarged Repertoire of Materials Concerning the Pastoral Ministry

The project has provided the writer with an enlarged amount of materials concerning the pastoral ministry both in and out of the SDA church. These may be useful to the writer in many ways. At the present time the writer is under appointment to teach in the theology department of Helderberg College, Somerset West, South Africa. Having served there for six years prior to his recent pastoral experience, he is aware that the materials should be useful there in teaching and preparing young men for the Seventhday Adventist ministry. The study somewhat indicated to the writer that, at present, he would likely experience less stress in teaching than in pastoring. It is significant, therefore, that the invitation to return to the classroom came subsequent to his decision to resign his pastorate. The indications of providence seems to support the findings of this study. 
Personal Insights and Self-assessment

The design of this study included a self-examination by the pastor as well as an analysis of the local church. Considerable insight was gained by the writer concerning his own strengths and weaknesses. This may be the most beneficial aspect of the entire study. The nature of these insights are such that perhaps they may best be stated in a more persona] way. These insights have not only affected me in my ministry but they have also affected my personal life at home, with friends, and relatives. I am more comfortable with myself and therefore more comfortable with others. I am less apprehensive. I am more confident in my competence to perform an effective ministry. A much broader perspective of the pastoral ministry has opened to me as the result of this study. I now understand why, at times, I have experienced stress in the local pastorates where I have served.

There are some areas in which additional growth, development, and improvement are indicated:

I will need to:

1. Seek a balance between my work life and my personal, recreational, and social life that is compatible with both my family and myself--in other words, begin to live on all fronts.

2. Structure ways of implementing a negotiative ministry in the local church--make it practical.

3. Continue to expand my resource material concerning implementing an intentional ministry with a view to developing a negotiative manual for 1 local pastors." 
4. Apply the negotiative process to the nonpastoral relationships--home, family, and classroom.

This project was conceived as an analysis of a local SDA church's expectations of its pastor in terms of attitudes, work life, and leadership style. It was also designed to suggest a model by which possible role conflict experienced by the pastor may be resolved. This model suggests that the pastor negotiate his role conflicts with his congregation and conference openly rather than keeping them to himself. It means the pastor must initiate the process, make his own self-assessment, and obtain information from his congregation and conference concerning their expectations of him. When this is done the negotiative process may begin. Out of this process a newly created ministry emerges that is mutually agreed upon and mutually implemented.

The Seventh-day Adventist local church appears ready and in urgent need of a new approach to ministry. The model suggested in this study seems to provide an organizing principle with which to begin. 
A. P P E N D I C E S 
APPENDIX A

SURVEY FORM USED IN THIS STUDY 
312 H1llcrest Drive

Berrien Springs, Michigan 49103

Dear Friends and Members of the Central Church:

As you know, I am working on a special project toderd the Doctor of ininistry Derree at Andrews University. You can be a great help to me if you will take just a fer moments to fill out the accompanying questionnaire. It will be very nuch eppreciated.

project theme is an analysis of the role expectations of the Senior pestor of the Central Seventh-iay idventist Church of Grand hapids. as one of those involved in trie Iffe of this church, you cen be of great help in determining what is excected of the senior pastor in setting his priorities end perhops assist nim in ovoiting serious conflict or embiguity in his work for the church. In so doing, you will not only be helping me in my doctoral project, but helping guice future pastors wino mey have access to our findings.

Thenk you for your cooperation.

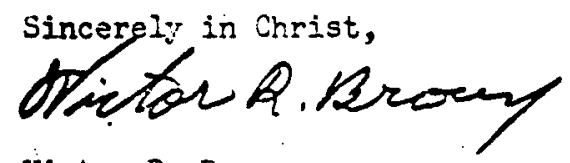

Victor R. Erom

Directions for filiing out this questionneire:

1. You need not place your neme anywhere on this questionnire. You ere asked to remain anonjwous.

2. kespond to each statement by circling the number under the response you kish to make. Here is a sample:

The G.R. Central pastor should:

AESCLUTELY PLEFËTLELY IUYY OR FEEF. SESCLUTELY irUST SticULD ILY NCT SHCULD SHCULD

Give. many Bible studies in the homes of non-menters.

1

2

3

4

5

3. Circle only one of the five numbers.

4. Your personal coments, questions, or sugzestions ray be made in the sfoce provided at the end of the questionnaire.

5. Before going further, would you please check the following:

Ny approximate age is: (Circle one) Under $20 \quad 20-35 \quad 36-49 \quad 50-64$ uver 65

nale Femele

Nottendence pattern at tine Central Church may be described as: Almost every week__2-3 times per moriti__ Not more than once a month Less than 10 times per year. ivever attend

6. Please turn to the first poge and begin your response. It should only take you $\theta$ Sew minutes. 
SECTION I. THE ADMINISTRATIVE AND ORGANIZATIONAL EXPECTATIONS FCR THE G.R- FASTOR

The Grand Rapids Central pastor should:

1. Serve as chaiman of the Church Boord.

2. Serve as an ex-officio nember of all other boards and comnittees set up by the church.

3. Have charge of all fund raising programs of the churcin such as the Combined burget, Building fund, etc.

4. Personally direct the Ingathering program.

5. Promote all ilich. Conf. stconsored cainpaigns such as ieligious iiberty, Listen biagezine, These Times, Feview ond Herald and all Speciel offerings.

6. jisintain en office in the churcin.

7. Have regular hours when he may be reached at the church office.

8. Do his own church office work such as letter r.riting, filing, and record keeping.

9. Rely wholly upon volunteer secretarial help who are wiliing to work without poy.

10. Expect his wife to act as his secretary. I

11. Expect to be cellert on to offer prayer when at gatherings where preyer is needed.

12. Oversee the training of church officers in their duties.

13. Map out plans for the overall church program for out-reach evangelisin and care of new members.

14. Not be a voting nember of comititees and boerds on which he is an ex-officio nember.

15. Expect to serve as a member of the Mich. Conf. Executive Comittee.
AESCWTELY PLEFEFFUELY MHY OR PREF. HESCCL. MUST SHOULD

WHY NOT SHCULO SHCUL?
1

1

1

1

1

1

1

1

1

1

1

1

1

1

1
2

2

2

2

2

2

2

2

2

2

2

2

2

2

2
3

3

3

NCT $\mathrm{NO} !$

45

45

5

$3 \quad 4$


SECIION I (COLTT.)

16. Oversee the weekly church bulletin ond monthly Newsletter.

17. ins District III juperintendent of the Hich. Conf. of S.J.4., he is to:

A. Conduct worship services in each of the other ten churches once per yea:.

B. Conduct pastor's councils every other montin or so for tine otiner pastors in the district.

C. Be available for emergency funerals, special calis when the other pastors are on vacation or gone for sore other reason.

18. Expect the church to provide either a paid or volunteer secretary to help him in his church office rork.
ABSOLUTELY FREFEHFELEL WUY CR FIEF. I.EECL. NUST SHOULD

MAY NOT SHCULD SHCULT

\section{1}

2

3

NOT NOT

1

2

3

4

5

1

1

2

2

3

4

5

2.

3

4

5

1

2

3

4

5

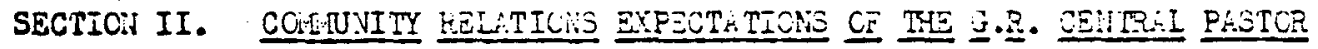

The G.R. Central pastor should:

19. Be a member of the Grand Rapids Kinisterial issociation which in-

1 eluries all denorinations in the city.

20. Become acguainted with the public officials such as the ileyor, City

1 Manazer, etc.

21. Ee sctive in one of the commuity service organizations, such as, Kiwanis.

22. Take an active pert in comanity service organizations that essist victins of social neglect, the poor and needy.

23. Delegate the writing of news erticles for the public newspoper to someone else rather than co it himself.

24. Act as chief public relations officer and thus make most of the contacts with the news media himself. 1

1

1

1

1
2

2

2

2

2

2

2

34

5

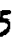

3.45

3.45

1.

$3 \quad 4 \quad 5$

3.45

5




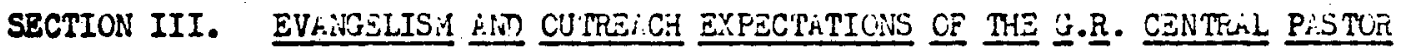

The Grand Rapins Central pastor should:

25. Personally conduct or arrange to have someone else confuct at least one evangelistic or revival series each jear.

26. Fegularly conduct Eible study series in the homes of non-members.

27. Train the church members in ministry by taking then with him as often as feasible.

28. Let others such as the rissistent pastor, qualified members make the initial contect on Voice of Prophecy, Foith for Todey, It is i.ritten, or other nomes sent to hin by tine iich. Conference office.

29. Spend most of his time helping church menbers be goor witnesses ratiner than conducting public evangelistic meetings.
AESOLUTELY PEEFERRIELY MAY OF FREF. hESOL. MUST SHOULD MAY NCT SHCULD SHCUL

1

2

$3 \quad 4$

5

1

1

1

2

34

5

1

2

345

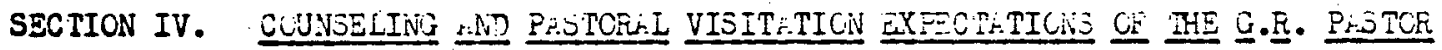

The Grand Rapids Central pastor should:

30. Go quickly to the bedsice of a member reportet seriously ill.

31. Wait until recuested before going to the bedsire of one reported seriously 111.

32. When death occurs in a church family, visit personally to confort those who mourn.

33. Visit the teminally ill frequently, but not daily.

34. Visit a hospital patient not more than one or two times in a 10-day stay.

35. Not visit out-of-town S.D.h. hospital potients unless specificsily requested
1

1

1

1

1

1
2

2

2

2

2

2
3

3

4

5 to do so. 


\section{SECTION IV. (CONT.)}

36. Serve as a unifying influence in the church by prescining powerful semons on unity.

37. When conflict occurs between nembers right away and try to help resolve the conflict.

38. Visit all the shut-ins at least once a month.

39. Spend most of his time visiting careless members and non-meabers trying to get then in tine church.

40. Visit every member family when the whole ferily is present at least once every two years.

41. Always pray when visiting church menbers.

42. huoid,es much as possible, personal counseling with women who are having marital problens.

43. Be willing to perform a counseling ministry to any and ell who may come to him for help.

44. Refer all persons tho come to him for counseling to the local counseling servicas available in the city. or groups in the church, go to work

ABSOLUTELY FEEFERRABLY MAY OR POEF. SESOL. MUST

SHOULD

ME.Y NOT SHCULD SHCULD

1

2

NOT NOT

1

2

3

4

5

1

1

1

1

1

1

1

$\begin{array}{lllll}2 & 3 & 4 & 5 \\ 1 & 3 & 4 & 5 \\ 1 & 2 & 3 & 4 & 5 \\ 2 & 3 & 4 & 5 \\ 1 & 2 & 3 & 4 & 5 \\ 2 & 3 & 4 & 5 \\ 2 & 3 & 4 & 5\end{array}$

SECTICN V. TERSOIJL END EAMLIY EXPICPTICNS

The G.R. Central pastor should:

45. Maintain a disciolined an regular time for prayer and personal tevotion.

46. Expect to improve his professional competence by trial and error rather than by attenting seminars and horkshops in his area of service.

1

1

2

34

5

2

3

4

5

1

47. Be allowed to have certain amount of time off each year to improve himself professionally. 
SECTION V. (CCNT.)

48. Be at least a graduate from the seminary with a Master of nivinity degree.

49. Spend one day each week with his family relleved from involvement in any church or conference responsibility.

50. Spend at least an hour each tay during the remining six working days with his family.

51. Expect his wife to be available et 811 times for volunteer church york such as Community Services, Frientship visitation, being helpful where needed.

52. If in debt, expect his wife to obtain a job outsife tine nome to ennance nis income.

53. Keep a crofessionel distance between himself ent the church meirers avoiding close friendships with aryone in the chursin.

54. Form most of his friendships outsice the local churein.

55. Expect nis chilfren to be goot exsmples to other chiltren.

56. Ee visible by attending nost of the religio's ent social functions of the ehurch.
ABSOLUTELY PREFERRLBLY YHY OR PEEF. ABECL. MUST

SHCULD

1

1

2

2

3

4

5

1

2

34

5

1

2

34

5

1

2

34

5

1

1

1

1

2

3

4

5

and speak at least three or more

Sabbaths per ionth.

58. Be present ant conduct the mid-week service, even though only a few people

1

2

3

4

5

sttend.

59. Ee present, but ask otiners such as the ossistant postor ant the elfers to help conduct the mid-week service.

60. Spent more time in serinon preparation then in any other activity.
1

1
2

2
345

34

5 
SECTION VI. (CCNT.)

61. Develop new ways of worship and get away from the monotony of the treditional ways followed at present.

62. Conduct a Sible stury occasicnally on Sebbati morning rather than preach a sermon.

63. Hllow feedback from the congregation about the sermon through group sessions during the following week.

ABSOLUTELY PEEFEZRLELY MEY OR PREF. HBSOL. WUST SHOULN WAY NOT SHCULD SHCNID

1

1

1

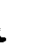

\section{2}

2

2

NOT NOT

$3 \quad \begin{array}{lcc} & \text { NOT } & \text { NOT } \\ & 4 & 5\end{array}$

\section{4}

5

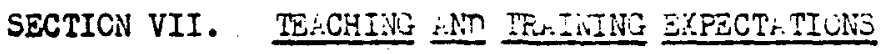

The Grand Repids Central pastor should:

64. Hiweys teach the Pestor's Eible class when present.

65. Personally supervise the instruction of those he plans to baptize.

66. Never baptize anyone without thoroughIy instructing beforehand.

67. Personally direct the witnessing-training program viti on-tine-job training plus classes.

68. Mrn over nost of the youth ministry to the assistant pastor.

69. Show pastoral interest in the youth and children but delezate otiners to lead out in the rinistry for thein.

1

1

1

1

1

1
2

2

2

2

2

2
34

5

5

5

5

345

1.

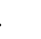

$\begin{array}{lll}3 & 4 & 5 \\ 3 & 4 & 5\end{array}$

2

SECTICN VIII. WCRK-iEEK-IILE IYFECIATICNS

70. Please circle the number of hours you expect the pastor of the G.R. Centrel S. R. $\dot{A}$. Church to put in each week in all focets of his ministry. Then underline tine number of hours you think he actually puts in per week.

$$
30-35 \quad 35-40 \quad 40-45 \quad 45-50 \quad 50-55 \quad 55-60 \quad 60-65 \quad 65-70 \quad 70-75
$$

\section{PhRT II}

Directions: This part of the questionnaire has to तo with the pastor's lestership style. You are asked to choose between two possible ways of reacting to certein situations. Select the one you would prefer to see in your pestor's legrership style. Simply draw a circle around the $A$ or $b$ of the statement thet you prefer. 
PART II (CONT.)

71. IN CCUISELING WITM PEOPLE AEOUT THEIK PEHSCNAI A.ND MOLHL PROBLEMS, THE PASTOR SHOULD:

\section{A}

Along with the healing porier of faith and prayer, he should utilize his ecqueintance witin humen neture geined from psychological studies and tine latest counseling te ciniques.

\section{$B$}

Depend entirely in the heeling pover of faith and proyer and his ability to see numan problems in the light of the Eible and the Spirit of Frophecy.

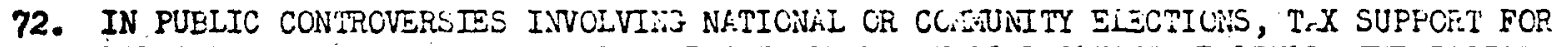

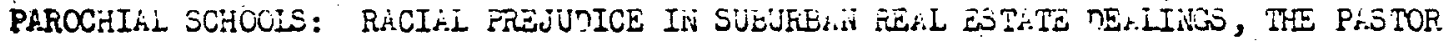
SHOULD:

\section{A}

Actively engage in promoting his opinion on the issue through or jenizations, circulation of petitions, etc.

\section{$B$}

Have his opinions but avoid becoming involved at ell in such metters ens? stick to preeching the Three ingel's Hessages.

73. THE G.R. PASTOE SHOUL BE IOTIVLTED BY:

A

A thorough conversion through winich he felt $\varepsilon$ reep call of God into tine ministry.

\section{B}

$A$ cesire to help people find the better life and help solve sociel problems in the Christien context.

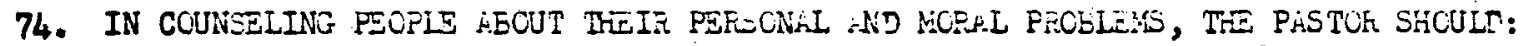

\section{$\dot{\mathrm{A}}$}

Express his opinions and constructive criticisms freeiy and sugjest changes in outlook.

\section{B}

r.ct es a patient and sincethetic iistener and let the courselee negctiste his own solutions to nis protlem.

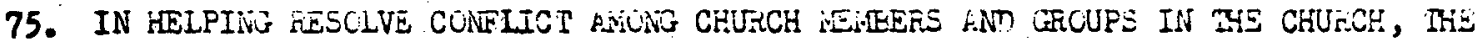
PASTOE SHOULT:

\section{A}

Try to reach a comprorise solution by acting as an iupertial mediator.

\section{B}

Take a clearly stated stand in the conflict and maintain it.

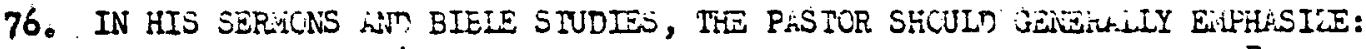

A

The importance of obtaining salvation and eternal life througn Cinrist in the future.
$B$

The importance of finding a richer, more joyful perscnel life on earth through Christ in the here and now.

77. IN HIS OVERALL NINISTRY TO THE G.R. CENTRIL CHUFCL, TRE PASTOK V.ILL BE VOST EFFECTIVE IF HE:

\section{A}

Sees himself as one minister among many ministers and tius treat every nember as - fellow-minister. lie thus sheres nis special competence when needed and helps others grow in their ministry as he is in his ministry.

\section{B}

Sees ninself as the chief prstor, prescher, teacher, evonielist, ind adninistrator en; aging the memkers of the church as nis helpers in doing the kork of God. 
PART II (CCNT.)

78. THE PHSTOR WILL BE UTOST SUCCE:SFUL IF HE: A

Clearly announces his personal gools for his pastoral career inf his goals for the time he is with the church, Inviting the church to join him in reaching the goals he hás set.

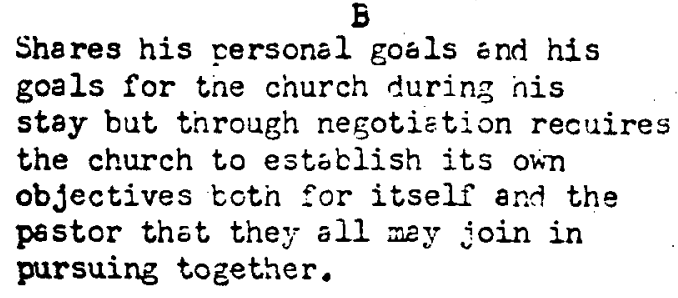
goals for the church during his stay but tinrough negotiation recuires the church to estaklish its own objectives totin for itself and the postor thot they all mey join in pursuing tozether.

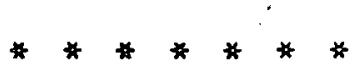

FEEL FREE TO JOT RIYTHING CN THE FOLLOING:

1. Observations and conments

\section{Questions}

\section{Suggestions}

THANK YCU FCE CCIPLETING THIS QUESTICNNAIFE. NCW PLCE IT IN THE ENCLOSED REIURN SELF-ADDHESSED ENVELOFE AND DHCP IT IN THE YMILEOX. THLANK YOU VERY IUCH. 
APPENDIX B

ENTS AND SUGGESTIONS BY RESPONDENTS TO THE SURVEY 


\section{VOLUNTARY COMMENTS AND SUGGESTIONS}

\section{BY RESPONDENTS TO SURVEY}

\section{Conference Employees}

\#13 If the pastor will use His God given logical good wisdom, most problems will work itself out if the preacher is under the power of the Spirit of the Lord.

\#15 Some of the questions are too and/or, where elements of both sides are correct, requiring a third answer, for clarification. Too many questions could be answered "Yay or may not" which. is too neutral.

\#18 Some questions tricky. Realize the job has many hats to wear. Family ones come first, we're all brothers and sisters. There just isn't enough time for all your jobs so delegate responsibility as Moses had to. Questions: How can you take this job (G.R.Pastor) knowing you' 11 have no security; as someday you will leave.

Suggestions: Continue the school of Biblical Studies. Expand it into more facets. Enroll more professors. Get more help.

\#19 Very fine questionnaire!

\#21 I believe the pastor should pastor all members. A few in Grand Rapids have had a tendency to make the youth feel that the pastor is too old to be able to understand or help the youth, and that they should have separate worship services Sabbath morning. Sorry to be so slow. Have not been home.

\section{Officers and Deacons}

\#26 The Grand Rapids pastor should show an interest in all departments of the church including the youth department and Community Services.

\#30 Have personally enjoyed the enthusiasm and obvious delight of your ministry in Grand Rapids. Appreciate your apparent concern for souls of those to whom you minister. Suggestion: More attention be given to finalizing details well in advance of a situation. Last minute requests for assistance or service tend to destroy respect for your ability to organize an effective ministry. 
\#37 My expectation for the church's minister: All pastors have their fields of interest, their strengths and weaknesses. Congregations have the right to expect to have the individual's need of the ministry be met but the lasting impact of a minister is going to come from the spiritual growth (or lack of $i t$ ) of that congregation that he was able to nurture. How he is able to bring this about--would be the goal. I felt columns $1-5$ are dictatorial and did not feel any pastor should be so rigidly instructed or counseled.

\#38 Not clear enough.

\#40 The last section is too complicated to have a specific honest answer.

\#42 In my experience, there are far more questions which cannot be answered with a yes or no--or with an either/or than there are which can be. In my opinion, most of the replies to most of these questions would depend on individual talents and abilities individual strengths and weaknesses. Since I cannot know those, I cannot give more specific replies, sorry.

\#45 Obs. and Comments

The Grand Rapids Central Church could kill a pastor quick. Quest.

When do pastors find time to prepare for sermons with all their expectations.

\#46 Obs. and Comments

Think all our preachers have done well and have done their best. Really have no criticisms. God has greatly blessed our church. We as members have more to do and much more to learn on how to function as nembers and share the pastor's load without taking over his function.

Pastor Brown:

This is really a mess. I've done some studying and I feel I have a clearer outlook on the function of a minister. It is almost like looking into a new world. The new knowledge is too new yet to be deeply certain how to answer these questions. I guess how to answer is "right or wrong"; it is my thinking that is really the answer here. This is your project, but the subject matter is a new fascinating study for me in my church life.

\#48 Obs and Comments

(2) Too general "al1 other boards and committees.

(8) Depends upon other duties and size of his church

(10). Wife should not work outside of home (or out of town)

(14) Many people look to the pastor to see how he votes, he should not influence their vote.

(13) With help and consultation with other members. 
(16) If done in an orderly way and not at the last minute.

(17) Depends upon the size of the church.

(60) Depends upon the person.

(68) Only if the assistant can work with the youth and have a good relationship with them.

\section{\#49 Obs. \& Comments}

Please don't turn outcasts and drunken folks away with no attempt to aid them to turn their hearts to God as they ask for help. Where our church is located it should first of all be a mission church for these ones downtown. Question.

Why turn them away because they might steal something or they have stolen something--without attempting to deal with them each personally. Maybe they don't smell nice. They have a soul to save. Nothing they can steal is worth a soul. Suggestions.

Appoint a large committee (on call) for folks who will want to deal and supply funds to feed and shelter them--and find where they can take them for a night's lodging. After the church turned them out a nonmember did this for you. Whatever you as a church do to the least you do or did to Christ--be mindful of the church's mission on earth. You may be losing a blessing from Him. Who gets blessed more they or us? I had a great blessing and shared it with my husband who helped at my side. He is a member. Try it! Is it against the law to do good or to do evil? With God all things are possible about who can be saved. Remember Lazarus--and the story of the good Samaritan. Who is our neighbor to love as oneself? It's happened twice that I've witnessed and served Him.

\#50 Suggestions.

Love all men and join in with our other Brothers and Sisters wherever possible. Hold united crusades with all churches in our district. And lets see God do miracles.

\#51 Most pastors are very conscientious about their duties. We recognize that pastors are human, too, and must have time to rest and refresh their minds. Probably most pastors work too hard. Their families are very important to us too. We are concerned for their health, their wife and children, too. Question.

Isn't it true that most pastors actually have to spend more than 75 hours a week in all facets of their ministry? Perhaps as many as 112 hours a week? Especially in a large church like Central.

Suggestion.

Speaking for one person, myself only, I definitely feel a pastor should definitely have one day off each week when he can be free to be with his family. Most of us would not begrudge him this. 
非2 Before seeking to find new members (he) should look in his own congregation for those that haven't been to church periodically. Also when there is a financial problem it seems like everyone is notified but during normal conditions only a few are always called on. The church is a self centered organization. If any questions on these comments, my name is (Name given).

\#53 Suggestion:

When a new minister comes try to ask everyone their name, and show an interest in everyone. Not just the ones who are officers in the church. Also if the nember doesn't give his name, the minister should ask. Maybe he wont' remember it the first time but at least he showed an interest. The minister doesn't know but some may become discouraged and quit coming to church if he doesn't show any interest at a11. Also when a new minister comes and says he will visit all homes and doesn't he had better not have said it. I know he is busy but people remember what he said.

\#54 I feel the pastor's wife should not work unless absolutely necessary, and be available--when needed. She should also be present at bridal and baby showers--"Women's" gatherings-of which the G.R. Church has suffered under the present leadership.

\#58 I don't understand Part II (It was left incompleted).

\#57 Very complete questionnaire, should help you and any other pastor in his work.

\#59 Question.

Does a minister leave a guide for a church when he leaves or not?

Suggestion.

Could the G.R. church have special projects to bring more money into the church and also to glorify the power of. God.

\#61 I have not been going to church for 2 years and have yet to have the pastor call at my home or on the phone to find out why. I feel that most pastors are more interested in obtaining new members than they are keeping the old ones. Suggestions.

I would like to see a pastor ask if he can visit with a person who is backsliding!

\#65 These questions are all very good and I feel should be strongly considered by all pastors especially. in taking up duties of a new congregation.

Suggestions.

More suggestions by all members as to the betterment and growth of the church would be good. 
\#71 Some questions were trickey--both answers could be correct.

\#76 No. 2--Leave to others, as teachers. No. 5--Attendance varies. Have to drive 25 miles one way to attend. Difficult to attend every Sabbath. Sorry also. No. 70--Depends on pastor, could not possibly answer this question. Question.

Why change pastors so often? Why is this necessary? Suggestions.

Would like to see more time in preaching salvation and less in ritual. I refer to the regular sermon.

\#84 A pastor should do the job as he sees it and has the time and ability to do it.

\#85 Pastor Brown, I didn't get some of the things on this questionnaire but I think it is a good idea. I didn't fill out the last part because. I didn't no what you meant, sorry. A member. (Name given) (11 year old girl).

\#87 He that endureth to the end shall be saved.

\#89 I observe that most ministers do all they can in the ministerial duties also visiting hospital patients. A few ministers show their interest in Community Services. When people are helped who really need it they are more ready to receive our literature and to accept Christ.

Suggestion.

I suggest that the ministers and their wives attend the Dorcas federation when at all possible and show their interest in all ways possible at least by visiting at the community services center at least once in a while for short visit when possible or practical. I think a minister should be interested and show their interest in a11. phases of church work as much as possible.

\#90. I feel the pastor should have less outside duties than presently G.R. pastors have. $\overline{B e}$ present also more in the G.R. church. Suggestions.

I suggest that all educational goals be completed before a pastor comes to a church of the size of the G.R. If more education is wished for then resign.

\#91 How come at church you treat some people that they don't even exist, and act like they are a pice of dirt, and that everybody else is to good for them. I go to that church but that way I quit going. You should try to be more friendly. 
\#94 I answered many questions with "may or may not" because I feel these are areas in which a pastor must be allowed flexibility--there are certain "grey" areas that can be ascertained only as conditions allow.

Suggestion.

I would like to hear occasional sermons from qualified lay members, if possible.

\#98 Good luck pastor Brown.

\#99 Sometimes a more extended interest of course without pressure and follow-up of prospective member as a result of evangelism, personal contact, etc. may produce greater results. Sometimes interested ones can be dropped too soon.

\#101 It is hard to answer some questions as has the poor pastor so much time to do all this.

\#103 I don't feel that, on a great many of the questions, there is a hard and fast, set answer. On many of them, my decision would be based on circumstances of an individual situation such as the people involved or the minister involved.

\#105 Question.

Why are the youth between ages 16 and 20 so much ignored? Why are there thirteen year olds in the youth?

Suggestion.

Ages for the youth should be from 16 years to 20 ! Rearrange it and then get something going!

\#107 How important it is that a public speaker in the G.R. church watch his word pronunciation, e.g., 'bad' and 'remnant.' Question.

Why leave those main doors open between the foyer and the sanctuary during services? How many rows of people are distracted by loud talking even laughing once in a while. Suggestion.

I suggest that when Sabb. School services or divine services begin the doors be closed by an attending deacon then opened at certain times. From the platform during S.S. opening exercises I've heard loud talking from those doorways, even the minister's voice.

\#108 I don't believe in a must or must not, in general, and think the pastor "must" be left in a free framework to do his work. It depends on the individual situation, left to the discretion of the pastor.

One thing I would like to add, Pastor Brown, to accept a sincerely given compliment (which has been richly deserved) does not take glory from God tends to unite the two--giver and receiver--in joyous fellowship and worship. 
\#115 Don't you think we should have a home for our Elderly people who can no longer live in their own home. Like the Holand people and Lutheran people have for their elderly. So we would not have to eat PORK. I would be glad to will our home to such a project and more too.

\#117 What can be done about parents who allow their children to scream and be so noisy during church services?

\#126 I am sure that adult Christian knows the boundaries of personal communion. However, pastors or laymen who cannot be outgoing will never reach the majority. Some people can't! They should be in other professions. Question.

Did Christ the greatest leader of them all, draw lines? With all due respect for professional ethics--(I, too had special training on that score) fishermen of men have to convince the world of their sincerity.

\#129. Be more aware of the needs of those that may be silent.

\#131 Too many questions could be answered in more than 1 way because of 1 word, .e.g, 非 35,44 they were hard to answer because of the various situations that could occur--if, and, but ... Suggestion.

Could the church members receive a copy of this survey with its combined results.

\#132 I feel that the minister's Bible class should teach the Sabbath School Lesson when they meet each Sabbath. We are supposed to study our lesson each day right?. It does not make sense to me to study daily and not be able to hear the lesson. I think others feel the same as I do. What do you think?

\#135. Circumstances could easily alter answers, I have given. I don't believe all members are qualified to answer these questions.

\#136 It would be nice to have the church service conducted the way the members feel it is most interesting. Question.

Would it be possible to cut out the advertisements between Sabbath school and church. Suggestion.

It would be nice to sing more familiar songs. More instrumental and special music presentations would be nice too. More church members need to be involved in the church's activities. 
\#144. Many times the assistant pastor takes over the preaching service and I don't expect to take home a blessing. Question.

Who enjoys the missionary period during Sabbath School. I don't feel any urgency to finish the work before the year 2000 .

Suggestions.

Let us continually call on the Lord and finish the work. I would like an explanation on what part of the world hasn't been covered by the everlasting gospel, and let us laymen do something about it. I would be willing to give my bank account to such a cause. It sure is frustrating when the work isn't likely to get done in my lifetime.

\#145 On question 55: Expectations for children are often unfair pressures. Lets give our "pastors" sufficient opportunity to be "parents" as well, and more of their children will be the children God desires. I did not feel qualified to express an opinion on many questions.

\#146 Very few things are an absolute must.

\#147 All ministers should spend a great deal of time preaching more heavy on the Spirit of Prophecy.

\#148 On number 76: I think it should be $A \& B$.

\#152 Page 2, Q. 16, The minister should not oversee the newsletter, on the bulletin--if he can have it ready by Thursday evening. So as the bulletin editor can type it before sundown. Page 5, Q. 52, A minister's family should not allow themselves to be in debt. It is not a good example to the church family.

\#153 As far as the pastor's wife working, I feel it should only be between them. If the church is not paying for the services of the wife, how can they expect them? After al1, only the pastor was hired, not his wife.

\#154 A wel1 rounded pastor should pay equal attention to all programs laid down by the church at the conference level, not only: his pet programs.

\#156 Impossible for one person to perform all the expected duties required. Not enough hours in a month without sleep or rest.

\#157 It is pretty hard to decide the right answer when you don't know how much work or time is involved.

\#161 A few times I encircled both which tells me both are important. 
\#168 We would like to be together as a church family, baptized, father, mother, and children alike to be visible as a family together. Question.

Who can we talk to when we need prayer for healing? Suggestion.

I suggest we pray about keeping families together especially now in this world of many changes.

\#177 It is a reflection on not only the minister but the church as a whole when he personally shows his appreciation for those who contribute to the "Special" such as a trio or solo numbers etc. I don't think it should be considered flattery to say a humble, sincere, courteous "Thank you"-so and so for that lovely solo. Thank you, Pastor Brown, you have done this!

Note: We, as a church, wish to express our sincere appreciation to you and your dear wife Alma for the implementation of the "Fellowship dinner." I said this on my own because I know it is true--there have been others making the same comments. It has helped us to become better acquainted with our brothers and sisters in the church. There are other benefits too. It makes our church become a "warm, friendly church." We really miss your Christian leadership. May God bless you and your family. Signing my name this time, (Name given).

\#190 I think the sermon should start on time and end at 12:00 prompt and not over.

\#201 It was hard to give a precise answer to some of the questions. Question.

Would more youth stay in the church if all of them could feel a part of the total group? If they have not been able to attend church school unless they have outstanding talents, they are not given much attention by church. The church school kids are very cliquish. If they only realized what a missionary work they could do by being friendly to the others. This relates mainly to the junior age down. Suggestions.

I feel if as much or even half as much time and effort was spent to visit and win back discouraged members as is spent trying to win even one new member, it would be great for our church. The visitation program has been a progressive and positive innovation, also the fellowship potlucks. Our church is much friendlier now. The positive and uplifting tone of the sermons over the past few years is appreciated. After seemingly years of verbal "spankings" for never measuring up. We can never measure up, only Christ's righteousness will do it. 
More effort should be made to use the musical talents of our members especially youth. A few perform over and over and many talented people are never asked or rarely. Please advise future pastors to advise the music director (of church or Sabbath school) to be sure an effort is made in the regard. About three years ago, a survey was made to ask each member what he would like to contribute in the way of helping his church, i.e., holding church office, teaching in a S.S. Dept. etc. This policy should be continued each year to give the nominating committee suggestions and also to utilize each one's talents and desires. I heard one of our members say who is now old and crippled, "I always wanted to be a deacon. I couldn't talk in front but I could have taken up the offering, etc., but no one ever asked me." I thought that was kinda sad. Thanks for letting me sound of $f$. 
APPENDIX C

LETTER OF INSTRUCTIONS FOR THOSE ATTENDING THE MIDWEST CAREER DEVELOPMENT CENTER 


\section{A WORD ABOUT YOUR PROGRAM}

The staff of the Center looks forward to your being with us for the three day program and in order to help you in planning and preparing for the best possible use of your time here, we are sending this outline of the basic program. The schedule is flexible. You and your counselor will discuss how your time can best be spent to best accomplish your goals in participating in the program.

In a broad, general, sense - here is the basic outline of a typical program.

- The first day you will spend in consultation with your career counselor developing reasonable and meaningful goals for your program. Additional time will be provided so you can explore facets of your personality and life-style with one of our clinical psychologists. You will also take some additional tests.

-- The second day testing is generally completed and a large block of time is spent with your career counselor.

- The third day you will have another block of time with the counselor to pull things together and to determine what goals and courses of action you may want to pursue after leaving the Center (i.e. Continuing Education, Personal Growth Experiences, Goal Setting Etc.)

- The evenings of the first and second days will be taken up, in part, with "homework" assignments to prepare you for the next day. However, there will be time for relaxing those evenings.

If your spouse is participating, the amount of time she or he will spend in the program can be determined by the nature of his or her concerns or objectives, and by what is most convenient. If possible, a participating spouse should be present for the first hour with the counselor.

The purpose of the Career Center program is to be of assistance to you. All of our efforts and expertise will be at your disposal. You should do some serious thinking, befcre coming, as to what you want from this experience.

The coffee pot is on (also tea, lemonade, and hot chocolate) and we look forward to meeting and sharing this experience with you. 
B I B L I O.G R A P H Y 
SELECTED BIBLIOGRAPHY

Books

Barr, Browne. Parish Backtalk. New York: Abingdon Press, 1964.

Bartlett, Liale E. The Vanishing Parson. Boston: Beacon Press, 1971.

Be11, Donald A. How to Get Along with People in the Church.

Grand Rapids, Mich.: Zondervan Publishing House, 1967.

Biersdorf, John E., ed. Creating an Intentional Ministry. Nashville, Tenn.: Abingdon Press, 1976.

Bowers, Margaretta, M.D. Conflicts of the Clergy: A Psychodynamic Study with Case Histories. New York: Thomas Nelson and Sons, 1963.

Bridges, Charles. The Christian Ministry. Guildford and London: Billing and Sons, 1830; reprint ed., London: The Banner of Truth Trust, 1967.

Dayton, Edward R. and Engstrom, Ted W. The Art of Management for Christian Leaders. Waco, Texas: Word Book, Publisher, 1976.

Dittes, James E. Minister on the Spot. Philadelphia: The Pilgrim Press, 1970.

Genera1 Conference of Seventh-day Adventists. Church Manual. Washington, D.C., 1963.

- Seventh-day Adventist Yearbook. Washington, D.C.:

Review and Herald Publishing Association, 1976.

Glasse, James D. Profession: Minister. Nashville, Tenn.: Abingdon Press, 1972 .

- Putting it Together in the Parish. Nashville, Tenn.: Abingdon Press, 1972 .

Glock, Charles Y., and Stark, Rodney. Religion and Society in

Tension. Chicago: Rand McNally and Company, 1965. 
Hadden, Jeffrey K. The Gathering Storm in the Churches. Garden City, N.J.: Doubleday and Company, 1969.

Hahn, Celia. The Minister is Leaving. New York: Seabury Press, Inc., 1974 .

Holmes, Urban T., III. The Future Shape of the Ministry. New York: The Seabury Press, 1971.

Hulme, William E. Your Pastor's Problems: A Guide for Ministers and Laymen. New York: Doubleday and Company, Inc., 1966.

Jacobsen, David C. The Positive Use of the Minister's Role. Philadelphia: The Westminster Press, 1967.

Jenkins, Daniel. The Protestant Ministry. Garden City, N.J.: Doubleday and Company, 1958.

Jud, Gerald.J.; Mills, Edgar W., Jr.; and Burch, Genevieve Walters. Ex-Pastors: Why Men Leave the Parish Ministry. Philadelphia: The Pilgrim Press, 1970.

Kent, Homer A., Sr. The Pastor and His Work. Chicago: Moody Press, 1963.

Kilinski, Kenneth K., and Wofford, Jerry C. Organization and Leadership in the Church. Grand Rapids, Mich.: Zondervan Publishing House, 1973.

Kittlaus, Paul, and Leas, Speed. Church Fights. Philadelphia: The Westminster Press, 1973.

Lavender, Lucille. They Cry Too! New York: Hawthorn Books, Inc., 1976.

Leach, William H. Handbook of Church Management. Englewood Cliffs, N.J.: Prentice-Ha11, Inc., 1958.

Leon, Raymond 0 . Manage More by Doing Less. New York: McGrawHi11 Book Company, 1971.

Linton, Ralph. The Study of Man. New York: Appleton-CenturyCrofts, Inc., 1936.

Lynd, Robert S., and Lynd, Helen Merre11. Middletown. New York: Harcourt, Brace and World, 1929.

Maves, Paul B., ed. The Church and Mental Health. New York: Charles Scribner and Sons, 1953. 
McCabe, Joseph E. How to Find Time for Better Preaching and Better Pastoring. Philadelphia: Westminster Press, 1973.

Michigan Conference of Seventh-day Adventists. Church Directory. Lansing, Michigan, 1976.

Narramore, Clyde M. The Psychology of Counseling. Grand Rapids, Mich.: Zondervan Publishing House, 1960.

Niebuhr, H. Richard. The Purpose of the Church and Its Ministry. New York: Harper and Brothers, 1956.

Niebuhr, H. Richard and Williams, Danie1 D. The Ministry in Historical Perspective. New York: Harper and Row, Publishers, 1956.

Nouwen, Henri J. Creative Ministry. New York: Doubleday and Company, 1971.

Oates, Wayne E. The Christian Pastor. Philadelphia: The Westminster Press, 1964.

01son, Richard Allan, ed. The Pastor's Role in Educational Ministry. Philadelphia: Fortress Press, 1974.

Oosterwal, Gottfried. Patterns of SDA Church Growth in America. Berrien Springs, Michigan: Andrews University Press, 1976.

- Mission Possible. Nashville, Tenn.: Southern Publishing Association, 1970 .

Pattison, Mansell E., ed. Clinical Psychiatry and Religion. Boston: Little, Brown, and Company, 1969.

Powe11, Milton, ed. The Voluntary Church. New York: The Macmillan Company, 1967.

Raines, Robert A. New Life in the Church. New York: Harper and Row, Publishers, 1961.

Rainman-Schindler, Eva, and Lippitt, Ronald. The Volunteer Community. Washington, D.C.: Center for a Voluntary Society, 1971.

Reid, Clyde. Groups Alive-Church Alive: New York: Harper and Row, Publishers, 1969.

Richards, Lawrence 0 . A New Face for the Church. Grand Rapids, Mich.: Zondervan Publishing House, 1974. 
Redenmayer, Robert N. We Have This Ministry. New York: Harper and Brothers, 1958.

Rouch, Mark A. Competent Ministry. Nashville, Tenn.: Abingdon Press, 1974.

Schaller, Lyle E. Parish Planning. Nashville, Tenn.: Abingdon Press, 1971 .

- The Pastor and the People. Nashville, Tenn.: Abingdon Press, 1973.

Segler, Franklin M. A Theology of Church and Ministry. Nashville, Tenn.: Broadman Press, 1960.

Shedd, William G. T. Homiletics and Pastoral Theology. London: The Banner of Truth Trust, 1965.

Skinner, Craig. The Teaching Ministry of the Pulpit. Grand Rapids, Mich.: Baker Book House, 1973.

Smith, Donald P. Clergy in the Cross Fire. Philadelphia: The Westminster Press, 1963.

Smith, Rockwell C., et. al. Sociological Studies of an Occupation. Roswe11, New Mexico: Ha11-Poorbaugh Press, 1966.

Stott, John R. W. One People. Downers Grove, I11.: Inter-Varsity Press, 1971 .

- The Preacher's Portrait. Grand Rapids, Mich.: Wm. B. Eerdmans Publishing Company, 1961.

Trueblood, E1ton. The Company of the Committed. New York: Harper and Row, 1961.

Turnbu11, Ra1ph G. A Minister's Obstacles. New Jersey: Fleming H. Reve11 Company, 1964 .

Walker, Daniel D. The Human Problems of the Minister. New York: Harper and Brothers, 1960.

Weeks, Howard B. Breakthrough. Washington, D.C.: Review and Herald Publishing Association, 1962.

White, Ellen G. The Acts of the Apostles. Mountain View, Calif.: Pacific Press Publishing Association, 1911. - Christ's Object Lessons. Washington, D.C.: Review and Herald Publishing Association, 1941. 
- Conflict and Courage. Washingtin, D.C.: Review and Herald Publishing Association, 1970.

- Evangelism. Washington, D.C.: Review and Herald

Publishing Association, 1946.

- The Faith I Live By. Washington, D.C.: Review and Herald Publishing Association, 1958.

- Fundamentals of Christian Education. Nashville, Tenn.: Southern Publishing Association, 1923.

- In Heavenly Places. Washington, D.C.: Review and Herald Publishing Association, 1967.

- Ministry of Healing. Mountain View, Calif.: Pacific Press Publishing Association, 1905.

- Selected Messages. 2 vo1s. Washington, D.C.: Review and Herald Publishing Association, 1958.

- Testimonies for the Church. 9 vols. Washington, D.C.: Review and Herald Publishing Association, 1948.

- Testimonies to Ministers. Mountain View, Calif.:

Pacific Press Publishing Association, 1944.

Witty, Robert G. Church Visitation. Nashville, Tenn.: Broadman Press, $196 \overline{7 .}$

Wolff, Richard. Change in the Church: A Source of Hope. Philadelphia: The Westminster Press, 1971.

Encyclopedias

The American Peoples Encyclopedia. 1970 ed. S.v. "Grand Rapids."

The New Schaff-Herzog Encyclopedia of Religious Knowledge. Grand Rapids: Baker Book House, 1960. S.v. "Practical Theology."

The Reader's Digest Great Encyclopedic Dictionary. New York: The Reader's Digest Association, 1966.

Seventh-day Adventist Encyclopedia. Washington, D.C.: Review and Herald Publishing Association, 1966. S.v. "Michigan Conference." 
General Conference of Seventh-day Adventists. "Evangelism and Finishing God's Work." A paper presented to the Annual Council, 13-21 October, 1976. (Mimeographed.)

Gray, William, and Douglas, Lamson. "Predicting Ministerial Effectiveness." Ph.d. dissertation, Harvard University, 1957.

Metzger, Bruce M. "The Evolution of Organization in the Early Church." Paper presented at the Day-Higginbotham Lectures, Southwestern Baptist Theological Seminary, Ft. Worth, Texas, 14 February, 1974.

Milner, S. Burkett. "An Empirical Examination into the Ministerial Role Expectations of Clergy and Laity in the United Methodist church of the Illinois Area." Ph.D. dissertation, Northwestern University, 1970.

Stewart, Alexander D. "The Clergyman as Administrator." A research elective, Harvard Graduate School of Business Administration. 1961.

White, Arthur L. "The Authority of Ellen G. White Writings." Ellen G. White Estate, n.d. (Mimeographed.) 


\section{VITA SHEET}

\section{VICTOR RALPH BROWN}

Born on October 27, 1922 on a farm in West Central. Illinois, Victor Brown attended a one-room elementary school and a small town high school. Near the end of a three-year term of service in the United States Navy, he was converted to Christianity and joined the Seventh-day Adventist church in February 1946. He graduated from Emmanuel Missionary college (now Andrews University) with a B.A. degree in theology in 1951, M.A, in religion (Cum Laude) 1960, and the M.Div. in August of 1966. He was married to Alma Cummings in August 1948, and has three children.

He served as pastor of multi-church districts in Illinois from 1951 to 1964. Included among the churches he served in Illinois are Quincy, Champaign, Centralia, Alton, and So. Suburban. He served the Ferndale (now Troy), Michigan congregation unti1 1966 when he was called to teach theology and Greek at Helderberg College, Somerset West, South Africa, where he remained for six years. In January of 1974 he became the pastor of the Grand Rapids Central Seventh-day Adventist church. He continued at Grand Rapids until October 1976 at which time he returned to Andrews University as a part-time teacher and doctoral student. In July 1977, he returns to Helderberg College.

He has written several articles for Seventh-day Adventist periodicals. By invitation he appeared on television in Grand Rapids to discuss his church and denomination. 